\title{
ENGAGING WITH ADAT PEOPLE IN SUSTAINABLE FOREST \\ MANAGEMENT
}





\title{
ENGAGING WITH ADAT PEOPLE IN SUSTAINABLE FOREST MANAGEMENT
}

\author{
DISSERTATION
}

to obtain

the degree of doctor at the University of Twente, on the authority of the rector magnificus, prof.dr. T.T.M. Palstra, on account of the decision of the Doctorate Board, to be publicly defended on Wednesday, September 11, 2019. at $14.45 \mathrm{hrs}$

by

Hunggul Yudono Setio Hadi Nugroho

born in Yogyakarta, Indonesia

On November 07, 1967 
This thesis has been approved by

Prof. A.K. Skidmore, supervisor

Dr. Y.A. Hussin, co-supervisor

ITC dissertation number 361

ITC, P.O. Box 217, 7500 AE Enschede, The Netherlands

ISBN 978-90-365-4837-3

DOI $10.3990 / 1.9789036548373$

Cover designed by Hunggul Y.S.H Nugroho

Printed by ITC Printing Department

Copyright (C) 2019 by Hunggul Y.S.H Nugroho

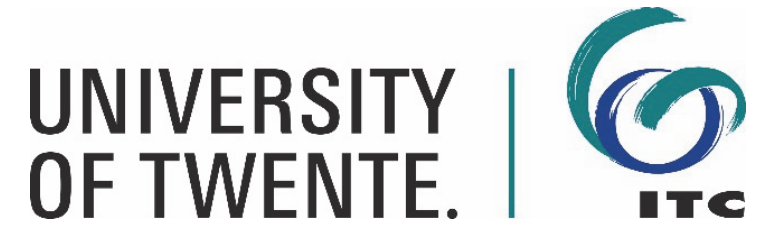


Graduation committee:

\section{Chairman/Secretary}

Prof.dr.ir. A. Veldkamp University of Twente

Supervisor

Prof.dr. A.K. Skidmore

University of Twente

Co-supervisor

Dr. Y.A. Hussin

University of Twente

Members

Prof.mr.dr.ir. J.A. Zevenbergen

University of Twente Prof.dr. P.Y. Georgiadou

Prof.dr. R. De Wulf

Prof.dr. R.G.A. Boot

University of Twente

University of Gent, Belgium

University of Utrecht 



\section{Acknowledgements}

First and foremost, I would like to thank God Almighty for giving me the strength, knowledge, ability and opportunity to undertake this research study and to persevere and complete it satisfactorily. Without His blessings, this achievement would not have been possible.

This thesis summarizes years' worth of effort, frustration, and achievement. However, there are several people with whom I am indebted for their contribution to the research, study, and dissertation of this thesis. I would like to convey my appreciation and thanks to all of you who helped me during my Ph.D. research.

My full appreciation and sincerest thanks go to my promoter Prof. Andrew K. Skidmore for his encouragement, support, and scientific guidance during my Ph.D. research. My gratitude also goes to Dr. Yousif A Hussin, my copromoter, for his daily support, guidance, and friendship during my study in ITC. I would like to express my acknowledgment to Emeritus Professor Anne van der Veen (ITC) and Emeritus Professor Soeyitno Sudirman (UNMUL), my previous promoters, for their support and guidance before retirement. Their constructive comments on the thesis were invaluable.

I am very grateful to The Minister of Environment and Forestry, The Head of Research, Development and Innovation Agency, Ministry of Environment and Forestry and The Head of The Environment and Forestry Research and Development Institute of Macassar, Indonesia, who gave me permission to do a Ph.D. and support my research with the fund.

Special thanks go to Prof. Dr. Rene Boot, Dr. Roderick Zagt, and Mr. Hans Lijftoght from The Tropenbos International, The Netherlands office, and Dr. Petrus Gunarso, Dr. Edi Purwanto, Sahid Robijaksani, Monang Panjaitan, Kresno Santosa, Aritta, Tika, Irene, Eko Manjela (alm), Yuli, Pak Sariman (alm), Pijar, mas Aries from Tropenbos Indonesia Programme who facilitate me with fund, data, office facilities, and transportation during my study.

Special thanks to Esther Hondebrink, Petra Weber, Theresa van den Boogaard and Ms. Loes Colenbrander from ITC, The University of Twente for their administrative assistance during my studies in The Netherlands and Mrs. Glen Mulcahy for the diligent proofreading and constructive suggestion of this thesis.

Very special thanks go to Ibu Dewi Pikaar Nurhamad, mbak Tyas M. Basuki, Anas Fauzi, Ratna Sari Dewi, Nugroho Christanto, Winardi, Nasrullah, Laila Zulfikar, Budi Ds, Riswan Sianturi and Novi Rahmawati. Thank you very much 
for your warm relationship, the dinners, lunches, weekends leisure, and for sharing the happy and the difficult times during our stay in Enschede.

Many thanks to my colleagues Pak Kudeng, Pak Hasnawir, Bu Mery, Bu Halidah, Bu Indra, Pak Heru, mas Bayu, Pak Saad, Pak Yudi, Pak Ade, Pak Mursidin, Fajri, Bu Dona, Pak Budi Hadi Narendra and administration staff in Environment and Forestry Research and Development Institute of Macassar, Indonesia for friendship, discussion and administrative supports. I will not be able to mention each of you here separately.

My gratitude also goes to pak Dedy Hermasyah (Pak Debang), Jidan and the people of Muly, Swan Slutung, Rantau Layung, Rantau Buta for the warm hospitality and data support during my 4 years field work.

Finally and most importantly, I would like to thank my wife, my children, my mother and my entire family. It would have been almost impossible to conduct this Ph.D. without the understanding, praying, and encouragement of my beloved wife Yory Tammu, my son Marvel Khyas P Yudo, and my daughters Aura Khyas Yudowati and Femme Khyas Yudhani. My deepest respect and thanks to my mother, Supadmi Kumala, your continuing praying, and support were invaluable. To my sisters and brothers, Joko Suryono, Swawi Astuti, Narmiyanto, Sulastri Juhariyah, Amalia Kartini, Untung Darajat, Agus Giri Marwoso, Yudiadi Hasto Bawono (alm) and Yulius Hanung Yudono, thank you very much for your support. 
I dedicated this thesis to:

The memory of my late father, S.Asmoro Yudohardjoso, who always believed in my ability to be successful in the academic area. I miss you every day with love and eternal appreciation.

My beloved mother, Supadmi Kumala, who never stop praying and giving of herself in countless

My dearest wife, Yori Tammu, who accompany me through the good and bad days with love and support,

My beloved kids: Marvel Khyas P.Yudo; Aura Khyas Yudowati, and Femme Khyas Yudhani who always be a continuous source of motivation and enlightenment 


\section{Table of Contents}

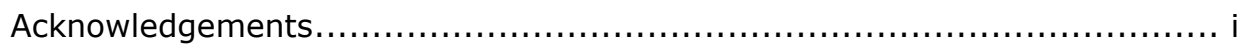

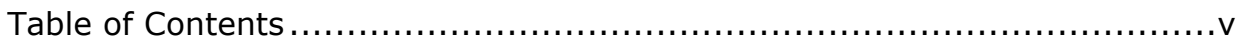

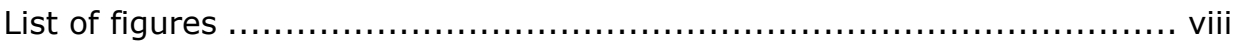

List of tables........................................................................ vii

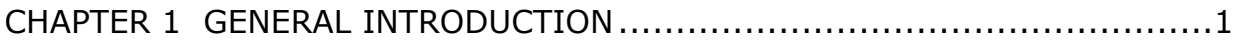

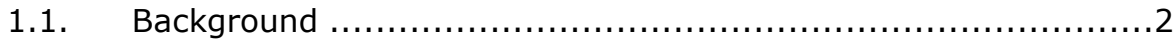

1.2 ADAT people and Forest management in Indonesia ................4

1.3 Research Objectives ..................................................

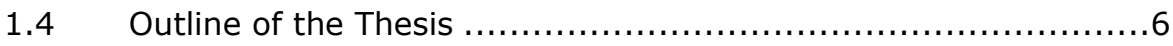

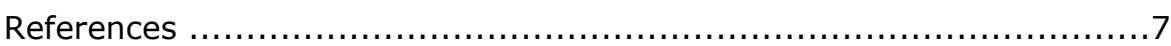

CHAPTER 2 THEORETICAL FRAMEWORK FOR SPATIAL PLANNING AND FOREST MANAGEMENT IN INDONESIA: SECURING THE BASIC RIGHT OF

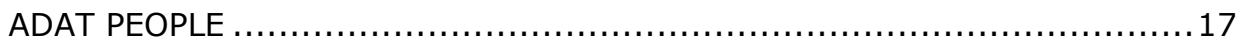

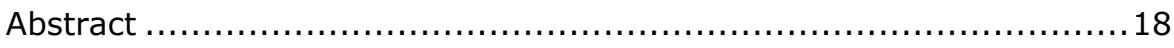

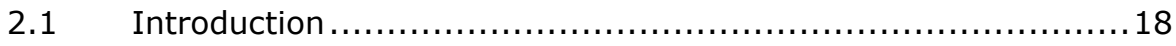

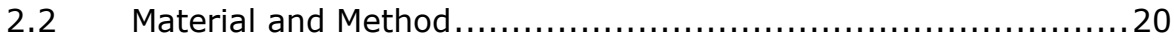

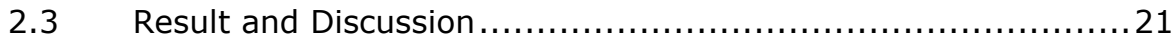

2.3.1 Administrative Reforms: Traditional versus Modern ...............21

2.3.2 Spatial Planning, Forest Governance and ADAT Rights in Indonesia ......................................................... 22

2.3.3 Theoretical Framework Towards a Solution .........................24

2.3.4 Determining Appropriate Institutions ............................. 25

2.3.5 Synergizing Resources, Needs and Knowledge for Policy Formulation ....................................................... 26

2.3.6 Determining Appropriate Tools and Mechanisms for Policy Formulation: from Normative Into Measurable Policies ............27

$2.4 \quad$ Conclusion .............................................................. 30

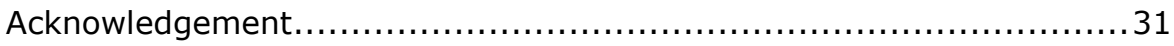

References .................................................................. 32

CHAPTER 3 EXPANSION OF TRADITIONAL LAND-USE AND DEFORESTATION:

A CASE STUDY OF AN ADAT FOREST IN THE KANDILO SUBWATERSHED,

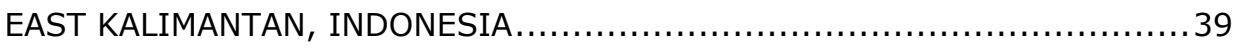

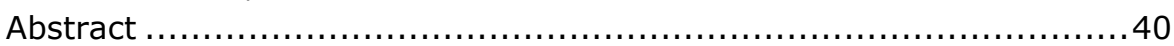

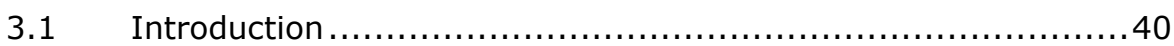

3.2 Material and Methods ........................................... 42

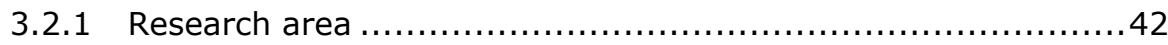

3.2.2 Data preparation ................................................. 44

3.2.3 Analysis of Existing traditional land-use expansion................46

3.2.4 Modelling traditional land-use expansion and forets conversion. 46

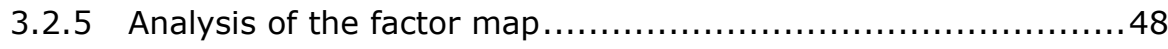

3.2.6 Model validation .................................................... 49

3.2.7 Scenario development and model simulation....................... 49 


\begin{tabular}{|c|c|}
\hline .3 & esults. \\
\hline 3.3.1 & Traditional land-use expansion for the period $1992-2012$. \\
\hline 3.3 .2 & Projected traditional land-use expansion and deforestation ......55 \\
\hline 3.3 .3 & 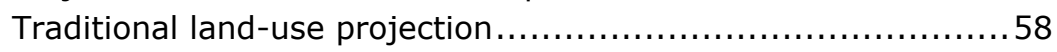 \\
\hline 3.4 & Discussion .............. \\
\hline 3.5 & Conclusion.. \\
\hline \multicolumn{2}{|c|}{ Acknowledgement.. } \\
\hline \multicolumn{2}{|c|}{ References } \\
\hline \multicolumn{2}{|c|}{ CHAPTER 4 DO TRADITIONAL KNOWLEDGE AND ADAT LAW STILL EXIST?.73 } \\
\hline \multicolumn{2}{|c|}{ 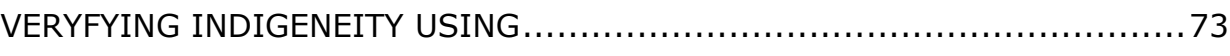 } \\
\hline \multirow{2}{*}{\multicolumn{2}{|c|}{$\begin{aligned} \text { REMOTE SENSING AND SPATIAL INFORMATION } \\
\quad \text { Abstract } \ldots \ldots \ldots \ldots \ldots \ldots \ldots \ldots \ldots \ldots \ldots \ldots \ldots \ldots \ldots \ldots \ldots \ldots \ldots \ldots \ldots \ldots \ldots \ldots\end{aligned}$}} \\
\hline & \\
\hline 4.1 & Introduction... \\
\hline 4.2 & Metho \\
\hline 4.2 .1 & Resea \\
\hline a. & Conforr \\
\hline b. & ADAT I \\
\hline 4.3 & Resu \\
\hline 4.3 .1 & Conf \\
\hline 4.3.2. & ........84 \\
\hline 4.4 & $\ldots \ldots \ldots \ldots \ldots 91$ \\
\hline 4.5 & $\ldots .99$ \\
\hline 4.6 & Acknowledgement... \\
\hline \multicolumn{2}{|r|}{ 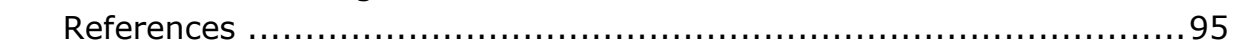 } \\
\hline \multicolumn{2}{|c|}{ CHAPTER 5 ENGAGING WITH INDIGENOUS PEOPLES IN SUSTAINABLE } \\
\hline \multicolumn{2}{|c|}{ FOREST MANAGEMENT } \\
\hline \multicolumn{2}{|r|}{ 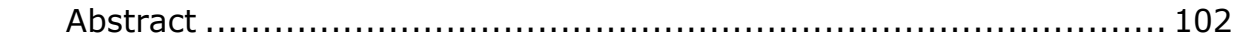 } \\
\hline 5.1 & Introduction.... \\
\hline 5.2 & T People : Stru \\
\hline 5.2 .1 & ..... 104 \\
\hline 5.2 .2 & ... 105 \\
\hline 5.3 & ... 108 \\
\hline 5.3 .1 & ....108 \\
\hline 5.3 .2 & $\begin{array}{l}\text { Financial and technical capacity of the ADAT people in } \\
\text { implementing SFM }\end{array}$ \\
\hline 5.4 & $\begin{array}{l}\text { Building long term engagement }: \text { coping with constraints and } \\
\text { challenges }\end{array}$ \\
\hline 5.5 & $\ldots .120$ \\
\hline 5.6 & Acknc \\
\hline \multicolumn{2}{|c|}{ References } \\
\hline \multicolumn{2}{|c|}{ CHAPTER 6 SYNTHESIS } \\
\hline & 13 \\
\hline .2 & Adaptive fore \\
\hline
\end{tabular}


6.3 Image interpretation, spatial modelling and sociocultural survey: mixed methods to analyze existing and future pattern of traditional landuse and deforestation and how to response..... 142

6.4 Substantial evidence of indigeneity: "de facto" recognition..... 143

$6.5 \quad$ Engaging with ADAT people...................................... 144

6.6 General conclusion ............................................. 146

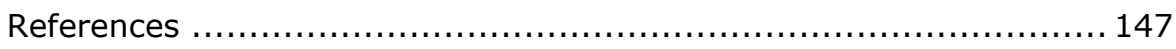

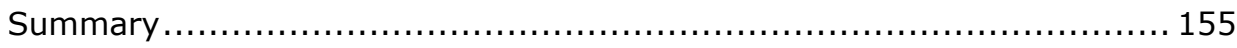

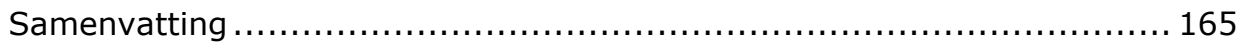

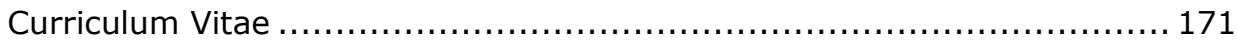




\section{List of figures}

Figure 2. 1. Framework of appropriate institution determination

Figure 2. 2. Framework for formulation of adaptive management technology

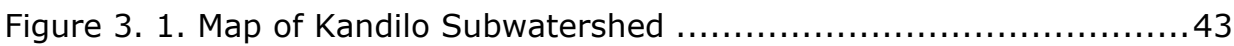

Figure 3. 2. Framework of spatial APM.................................... 48

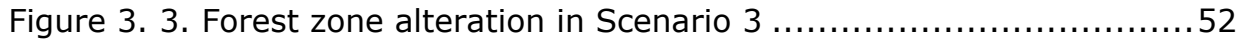

Figure 3. 4. Spatial distribution of traditional land-use expansion from 1992

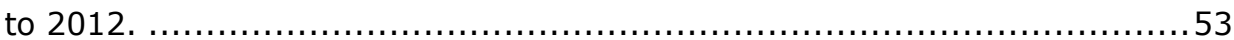

Figure 3. 5. Trends in land cover and land-use change from 1992 to 2012.. 54 Figure 3. 6. Distribution of traditional expansion based on slope of land and distance to the river, the road, and the settlement.......................... 55

Figure 3. 7. Map of ADAT forest of Muluy and Rantau Layung ................. 57

Figure 3. 8. Spatial distribution of the predictions for land-use conversion. .58 Figure 3. 9. Spatial distribution of agricultural expansion for three different

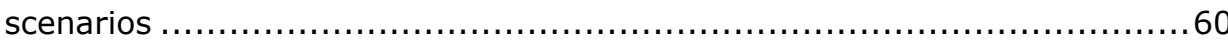

Figure 4. 3. Overlay of ADAT forest and forest designation. .................. 82

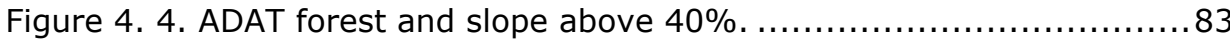

Figure 4. 5. Spatial distribution of changes of ADAT land-use of Muluy for the

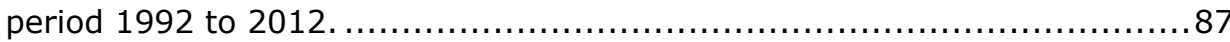

Figure 4. 6. Spatial distribution of changes of ADAT land-use of Rantau

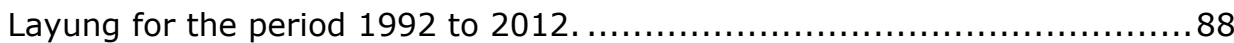
Figure 4. 7. Traditional land-use in Muluy and Rantau Layung 2012 ..........90 90 Figure 5. 1 Integrated verification process (Nugroho et al., 2018) ........... 111 Figure 5. 2. ADAT Forets of Muluy....................................... 118

\section{List of tables}

Tabel 2. 1. Differences between traditional administration and modern

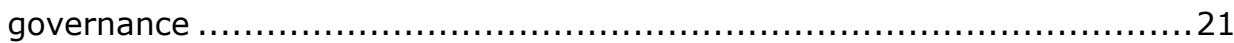

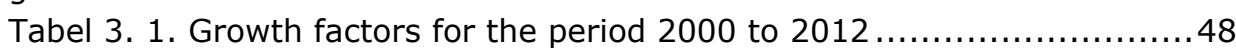

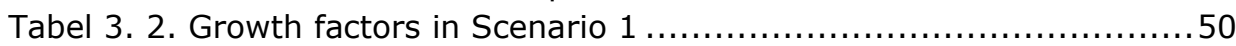

Tabel 3. 3. Growth factors in Scenario 2 .................................. 51

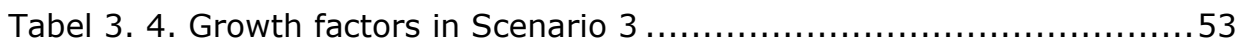

Tabel 3. 5. Deforestation per capita/year in three communities with different

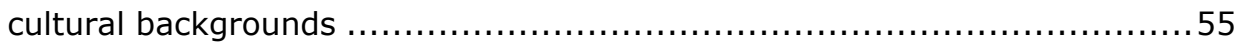

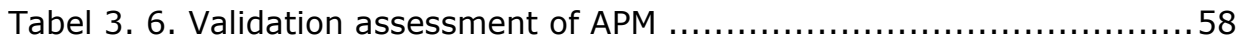

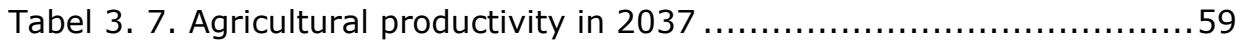

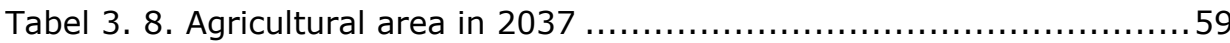

Tabel 3. 9. Projected traditional land-use expansion and deforestation .......60 Table 4. 1. General characteristic of the villages/kampongs in the study area.

Table 4. 2. The general characteristic of ADAT forest designation. ........... 81 
Table 4. 3. Distribution of Muluy ADAT forest based on forest designation. . 82 Table 4. 4. Distribution of Rantau Layung ADAT forest based on forest

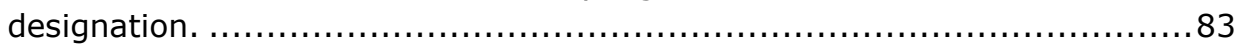

Table 4. 5. Distribution of Muluy forest based on slope class................... 84

Table 4. 6. Distribution of Rantau Layung forest based on slope class. ........84

Table 4. 7. Trends in ADAT land-use expansion of Muluy from 1992 to 2012.

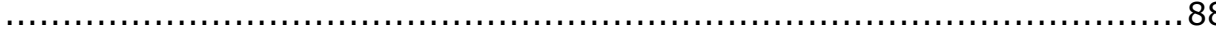

Table 4. 8. Trend in ADAT land-use expansion of Rantau Layung from 1992

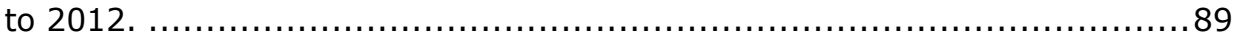

Table 4. 9. Predicted time remaining ........................................ 91 


\section{CHAPTER 1}

GENERAL INTRODUCTION 


\subsection{Background}

Issues related to deforestation, land degradation, and disharmony between stakeholders, have formed an ongoing theme in many international forestrelated workshops, scientific journals and publications for more than three decades. This interest is motivated by significant global deforestation and its effect on government revenue, environmental degradation, and the livelihood opportunities of forest-dependent people (Boafo, 2013; UNEP, 2011, 2012).

Empirical data across countries show that a main cause of forest destruction and conflict among stakeholders is weak governance, which is characterized by limited transparency, accountability, and participation (Carothers \& Brechenmacher, 2014; Drazkiewicz et al., 2015; Rodríguez Bolívar et al., 2015). Although concerns related to weak forest governance did receive attention in various international forums, there is still limited knowledge about the effect on deforestation, degradation, and livelihoods at local levels, as well as how to address this issue to attain Sustainable Forest Management (Blaser, 2010).

Sustainable forest management (SFM) can be simply defined as the process of managing forest to increase their economic, social, and environmental benefits continuously while avoiding forest degradation and deforestation (Bonsu et al., 2015; Bonsu et al., 2017; CPF, 2012; FAO, 2017; ITTO, 2017). It recognizes that stakeholders are an integral part of forest management and that their interests and values should be accounted for (Bonsu et al., 2017). At the social level, sustainable forest management contributes to livelihoods, income generation and employment. At the environmental level, it contributes to important ecosystems services such as carbon sequestration and water, soil and biodiversity conservation for the benefit of present and future generations (FAO, 2017).

Addressing the various demands of ecosystems services, there is an increasing concern on the importance of public participation in SFM (Bonsu et al., 2017; Grošelj et al., 2016; Rai et al., 2017; Sherpa \& Sinogba, 2016). Forest management must consider the need and aspirations of people whose livelihood depend on these resources to empower local communities and reduce threats while improving the condition of forest resources (Defries et al., 2007; Gbedomon et al., 2016; Rives et al., 2013; Sherpa et al., 2016).

In the International Workshop on Deforestation and the Rights of Forest Peoples held in Palangkaraya, Indonesia, March 2014, delegates agreed that forest destruction will not end without securing forest peoples' land and territorial rights. Measures must also be taken at all levels to ensure full participation of indigenous people, "who inhabit, use, have customary rights 
to, and rely on forests for their identity and survival", as a key stakeholder in decision-making (FPP et al., 2014). These statements are relevant with many research findings (Astuti \& McGregor, 2016; Chun, 2014; IWGIA, 2016; Larson et al., 2015).

However in practice, this is not a simple process. Various obstacles emerged both in terms of governance and the stakeholders involvement. The process of forest management decentralization have failed to engage indigenous peoples and local communities in a meaningful way (Gooda, 2010; Nick, 2014), due to lack of transparency and an overly technocratic approach (Gautier et al., 2015; Nick, 2014), lack of consideration of local knowledge (Gautier et al., 2015), and remains fraught with administrative inefficiencies and a mistrust of local communities (Gautier et al., 2015; Gbedomon et al., 2016; Miller \& Nadeau, 2016). On the other side, the widely accepted premise of indigenous people being a self-sustaining community with a strong connection to the forest linked by norms, beliefs and traditions (Arizona \& Cahyadi, 2013; Li et al., 2010; Mulyoutami et al., 2009; Sasaoka \& Laumonier, 2012; Wachira, 2010), are questioned not least from anthropologist (Kuper, 2003). Claims in the international policy discourse that community managed forests are better than state managed forests may be true, or not, but are rarely supported by evidence (Boedhihartono, 2017). There were numerous criticisms attacking overly exaggerated pictures of indigenous people (Grumblies, 2013; Muur, 2015). These critics related to a premise that indigenous peoples have changed in line with changes in economic and environmental conditions. The increase in population and culture diversity in the ADAT people's region, contact with external people with different values and attitudes, increasing necessities of life, and the need for cash might change the behavior towards nature of the indigenous people (Anthias, 2017; Huntington et al., 2004; Kothari, 2007; Luz et al., 2015; Muur, 2015).

In Indonesia, a country with more than 1,300 ethnic groups and more than 2,500 languages (BPS, 2010), issues related to indigenous people and customary right has been considered to be an intriguing issue for many years, especially since the regional autonomy era (Banjade et al., 2016; Royer et al., 2015). Engaging with ADAT people (Indonesian term for indigenous people) is not an easy task. Committed to the definition of ADAT law community, for those who have ancestral connection and a special relationship with the environment, and owning a value system governs economic, politic, social, and law institution, it remains difficult to verify who is indigenous and who is not (Arizona et al., 2013; Gauset et al., 2011; Muur, 2015; Nair, 2006; Royer et al., 2015). 
The issue has been more prominent after the Indonesian Constitutional Court on May 2013 ruled the decision No. 35 of 2012 (MK 35). The decision restores the rights of ADAT (indigenous) peoples to own and manage their territory by annulling the state's ownership to the ADAT forest as being ruled in Forestry Law No. 41/99. Following on from this decision, in the RPJM (Medium term development Plan) 2015-2019, the Indonesian Government committed to returning a total of 12.7 million hectares of land to local community and indigenous peoples for sustainable forestry, of which 20 percent will be taken from private concession areas. (Astuti et al., 2016; Fanani, 2017 ; Johnson, 2015; RAN, 2017). In fact, most of the ADAT community territories are located within forest areas. According to AMAN (Aliansi Masyarakat ADAT Nusantara/Indigenous Peoples' Alliance of the Archipelago), 90 percent of at least 84 million ha of ADAT communities' territories are forest (Zakaria, 2017), which is, without special measures, potentially lead to claim contestation, conflict among stakeholders and forest destruction. Thus, practical solutions are essential if sustainable forest management is to be achieved, while incorprating the appropriate institutions, mechanisms and tools to design and implement the sustainabilty strategy.

\subsection{ADAT people and Forest management in Indonesia}

The concept of indigenous people refers to people who are having historical continuity with pre-colonial society, by which the aboriginal peoples of a given land were marginalized after being invaded by colonial powers, whose people are now dominant over the earlier occupants (UN, 2009). This concept makes less sense in Indonesia where the colonial powers did not displace whole populations of people (Klenke, 2013; Tsing, 2002). In Indonesia, distinguishing 'indigenous' from 'non-indigenous' groups is complicated (Henley \& Davidson, 2007; Tsing, 2002). During Suharto's New Order regime, the official discourse was that all native Indonesians (pribumi) were in a sense indigenous so there were no 'indigenous people' as such (Royer et al., 2015; Tsing, 2002).

The Indonesian term ADAT means 'custom' or 'tradition' (Henley et al., 2007). It is used to describe complex customary systems, including rights to land and resources, a wide range of traditional rules, social rule, customs, conventions, principles, moral concept and beliefs (Affandi, 2016; Royer et al., 2015; Rye \& Kurniawan, 2017; Tyson, 2010). The term ADAT carries connotations of serene order and consensus (Henley et al., 2007). Yet, interpretation of $A D A T$ may vary within villages and between ethnic groups according to a wide variety of $A D A T$ laws regulating access to land and resources (Royer et al., 2015; Tyson, 2010). 
During New Order regime (1966-1998), the ADAT peoples were alienated from their land, often without proper compensation, in the name of development of infrastructure, as well as for mining and timber concessions (Arizona et al., 2013). They were referred to by the government as forest encroachers, uncivilized and isolated peoples (Arizona et al., 2013; Hartanto et al., 2008).

The turning point in the Indonesian political system from a highly centralized government to a new era of decentralization came in 1998 (popularly known as the reformation era). The reformation era has provided opportunities for local political elites throughout the country to build their own local power bases. ADAT has been one channel through which they have done so (Moeliono \& Dermawan, 2006). Indigenous rights discourses are becoming an important component of rhetorical debates and practical policies (Astuti et al., 2016). Using historical claims, several groups claimed their rights of land encompassing several smaller territories, sometimes even overlapping each other (Moeliono et al., 2006).

The significant result of ADAT fight for rights over land territory after 1998 were the issuance of Forestry Law 41/1999, and Decree of the People's Consultative Assembly (Ketetapan MPR, TAP MPR) IX of 2001 concerning Agrarian reforms and natural resources management, which gave explicit recognition of ADAT rights. However, despite the fact that many laws were initiated, these laws do not solve the existing problems (Kementerian PPN/BAPPENAS 2013). Forestry law stipulated that ADAT forest is part of state forest. Under the policy of Ministry of Forestry, communities and ADAT communities are only allowed to manage and use their rights on forest within a fixed framework of the Ministry(Moeliono et al., 2006). However, as a response of the Judicial Review against Forestry Law 41/1999 delivered by the Indigenous Peoples Alliance of the Archipelago (AMAN), in 2013, this stipulation was annulled by the Indonesian Constitutional Court decision No. 35/PUU-X/2012 (MK 35). The MK 35 confirmed that ADAT forests located in indigenous territories should no longer be considered as State Forests (Mahkamah Konstitusi Republik Indonesia 2013). Yet, ADAT communities are required to prove their existence supported by sufficient evidence to claim their traditional territory (Boedhihartono, 2017; Siscawati et al., 2017). The Ministry of home affair regulation Number 52 of 2014 stipulates five indicators of indigeneity for official recognition as ADAT law community: (a) history of the $A D A T$ law communities; (b) $A D A T$ territory; (c) $A D A T$ law; (d) $A D A T$ property relations, inheritance and $A D A T$ artifacts; and (e) customary governance system.

Nevertheless, looking at the existing rules (KATR/BPN, 2016; KEMENDAGRI, 2014; KLHK, 2015a; PSKL, 2016), the main approach to validate and verify 
the existence of ADAT people is still focused on legal-formal approach based on judicial and physical data. In fact, there are potential discrepancies between the existence and the implementation of ADAT law. We are concerned that the recognition process will only become an instrument for political persuasion as being mentioned by Kuper (2003), rather than being substantially considered as a tool for a better management of forest. We consider that rely merely on judicial and physical data is not enough to proof the indigeneity of ADAT rights claimants on forest. Li et al. (2010) defined indigeneity as permanent attachment of a group of people to a fixed area of land in a way that marks them as culturally distinct. In particular, government of Indonesia through The Agrarian State Ministry Regulation Num. 5/1999 confirmed that customary rights were adhered to group of people who are still bonded by the customary law and apply the rule in their daily living. Yet, ADAT rights is susceptible to misuse, and claims to ADAT rights should be considered on the basis of critical observations employing field research as well as historic data (Bakker, 2008).

\subsection{Research Objectives}

The general objective of this research is to generate appropriate mechanism to engage with ADAT people in SFM. The specific objectives of this research are:

- Developing a concept for the reform of forest-based spatial planning respecting the basic rights of the ADAT people, covering policy making as well as a way to introduce policy reform.

- $\quad$ Generating a better understanding of deforestation in correlation with traditional land-use expansion and promoting measures to develop more productive traditional land-use systems while decreasing deforestation.

- Examining substantial evidences to improve verification mechanism of recognition of ADAT rights over forest area.

- Examining appropriate measures in engaging with ADAT people to attain SFM.

\subsection{Outline of the Thesis}

This thesis consists of six chapters, linked together in trying to propose appropriate mechanism in engaging with ADAT people for sustainable forest management and community welfare.

Chapter 1 illustrates the general idea of comprehensive research in enabling ADAT people to engage in SFM: the background, the general information of ADAT people and forest management, and the challenges to improve previous mechanism to engage with ADAT people. In addition, chapter 1 also describes the objectives of the research. 
Chapter 2 presents the development of a concept for the reform of forestbased spatial planning respecting the basic rights of the ADAT people, covering policy making as well as a way to introduce policy reform. The main focus is the design of a practical mechanism incorporating decision support systems. The narratives of spatial planning and forest management incorporating ADAT rights is viewed using a theoretical framework in the context of an appropriate spatial planning governance.

Chapter 3 discusses the spatial patterns of existing and future trends in traditional land-use expansion and deforestation. Using an area production model (APM), we simulated the effect of improved traditional farming systems, policy intervention and law enforcement on traditional land-use expansion and deforestation spatially.

Chapter 4 introduces a new approach employing substantial evidences to improve verification mechanism of recognition of ADAT rights over forest area. Aimed to support legal-formal evidence, we employed spatial analysis supported by socio-economic and cultural analysis to examine the traditional knowledge and ADAT law implementation as substantial evidences of indigeneity.

Chapter 5 observes determinant factors, challenge and constraint in enabling ADAT people to engage in SFM.

Chapter 6 brings together all the research findings from the previous chapters. The contribution of the research findings to society and for forest management is explained. General conclusions are provided and future works are recommended.

\section{References}

Affandi, D. Y. (2016). Negoitating Adat. 22 Fepbruary 2016. Retrieved 20 September 2017, 2017, from http://www.insideindonesia.org/negotiating-adat

AMAN. (2014). 2013 in Review Indigenous Peoples' Alliance of the Archipelago 28 February 2014. Retrieved 22 November 2016, 2016, from http://www.aman.or.id/2014/02/28/2013-in-review-indigenouspeoples-alliance-of-the-archipelago-aliansi-masyarakat-adatnusantara-aman/

AMAN and AIPP (2017, April - May 2017). Joint Stakeholders' Submission on The Situation of Human Rights of Indigenous Peoples in Indonesia. 3rd Cycle of Universal Periodic Review of Indonesia; 27th Session of the Human Rights Council. Jakarta - Ciang Mai. 
Anthias, P. (2017). Ch'ixi landscapes: Indigeneity and capitalism in the Bolivian Chaco. Geoforum, 82(Supplement C), 268-275. doi: https://doi.org/10.1016/j.geoforum.2016.09.013

Ardanaz, M., Leiras, M., \& Tommasi, M. (2014). The Politics of Federalism in Argentina and its Implications for Governance and Accountability. World Development, 53, 26-45. doi: http://dx.doi.org/10.1016/j.worlddev.2013.01.004

Arizona, Y., \& Cahyadi, E. (2013). The Revival of Indigenous Peoples: Contestations over a Special Legislation on Masyarakat Adat. In B. Hauser-Schäublin (Ed.), Adat and Indigeneity in Indonesia Culture and Entitlements between Heteronomy and Self-Ascription (Vol. 7, pp. 43-62). Göttingen: Göttingen University Press

Astuti, R., \& McGregor, A. (2016). Indigenous land claims or green grabs? Inclusions and exclusions within forest carbon politics in Indonesia. The Journal of Peasant Studies, 1-22. doi: $10.1080 / 03066150.2016 .1197908$

Bakker, L. (2008, April 25-26). "Can We Get Hak Ulayat?": Land and Community in Pasir and Nunukan, East Kalimantan. Paper presented at the UC Berkeley-UCLA Joint Conference on Southeast Asia, "Ten Years After: Reformasi and New Social Movements in Indonesia, 1998-2008", The University of California Berkeley, California.

Banjade, M. R., Herawati, T., Liswanti, N., \& Mwangi, E. (2016) Tenure reform in Indonesia, When? What? Why? , iNFO bRIEF: Vol. 163 (December 2016 ed.). Bogor: CIFOR.

Blaser, J. (2010). Forest law compliance and governance in tropical countries, A region-by-region assessment of the status of forest law compliance and governance, and recommendations for improvement. In A. Sarre (Ed.), (pp. 1-28): FAO and ITTO.

Boafo, J. (2013). The Impact of Deforestation on Forest Livelihoods in Ghana. BACKGROUNDER. AFRICAPORTAL. Retrieved from http://www.africaportal.org/sites/default/files/Africa\%20Portal\%20Ba ckgrounder\%20No.\%2049.pdf

Boedhihartono, A. K. (2017). Can Community Forests Be Compatible With Biodiversity Conservation in Indonesia? Land 6, 21, 17. doi: 10.3390/land6010021

Bonsu, N. O., Dhubháin, Á. N., \& O'Connor, D. (2015). Understanding forest resource conflicts in Ireland: A case study approach. Land Use Policy. doi: https://doi.org/10.1016/j.landusepol.2015.11.009

Bonsu, N. O., Dhubháin, Á. N., \& O'Connor, D. (2017). Evaluating the use of an integrated forest land-use planning approach in addressing forest ecosystem services conflicting demands: Experience within an Irish forest landscape. Futures, 86(Supplement C), 1-17. doi: https://doi.org/10.1016/j.futures.2016.08.004 
BPS. (2010). Kewarganegaraan, Suku Bangsa, Agama, dan Bahasa Seharihari Penduduk Indonesia, Hasil Sensus Penduduk 2010. Jakarta: Subdirektorat Statistik Demografi, Badan Pusat Statistik.

BPS Kabupaten Pasir (2011). Kabupaten Pasir Dalam Angka 2011. Tanah Grogot: Badan Pusat Statistik Kabupaten Pasir.

Bressers, H. T. A., \& Kuks, S. M. M. (2003). What does governance mean? From conception to elaboration. In H. T. A. Bressers \& W. A. Rosenbaum (Eds.), Achieving Sustainable development: The challenge of Governance Across Social Scales (pp. 43-64.). Westport Connecticut: Praeger Publishers

Cahyadi, F. (2014a). Pidato Sekretaris Jenderal (Sekjen) AMAN \#HKMAN2014. 18/03/2014. Retrieved 16 September 2017, 2017, from http://www.aman.or.id/pidato-sekretaris-jenderal-sekjen-amanhkman2014/

Cahyadi, F. (2014b). Satgas Nasional Pengakuan dan Perlindungan Masyarakat Adat Mulai Dibentuk. 17 November 2014. Retrieved 9 February 2017, 2017, from https://www.aman.or.id/2014/11/17/satgas-nasional-pengakuandan-perlindungan-masyarakat-adat-mulai-dibentuk/

Carothers, T., \& Brechenmacher, S. (2014). Accountability, transparency, participation, and inclusion, a new development consensus? Washington DC: Carnegie Endowment for International Peace.

Chun, J. (2014). A legal approach to induce the traditional knowledge of forest resources. Forest Policy and Economics, 38(0), 40-45. doi: http://dx.doi.org/10.1016/j.forpol.2012.07.006

Cimpoeru, M. V., \& Cimpoeru, V. (2015). Budgetary Transparency - An Improving Factor for Corruption Control and Economic Performance. Procedia Economics and Finance, 27, 579-586. doi: http://dx.doi.org/10.1016/S2212-5671(15)01036-9

Coutant, D., Riggs, D., \& Van Sant Hoffman, E. (2011). Substantial Evidence: When is a Single Trial Sufficient for Approval and Promotion? Drug Information Journal, 45(3), 253-263. doi: $10.1177 / 009286151104500306$

CPF. (2012). SFM and indigenous peoples (Vol. SFM fact sheet 4): Collaborative Partnership on Forest.

Defries, R., Hansen, A., Turner, B. L., Reid, R., \& Liu, J. (2007). Land Use Change around Protected Areas: Management to Balance Human Needs and Ecological Function. Ecological Applications, 17(4), 10311038. doi: $10.2307 / 40061895$

Drazkiewicz, A., Challies, E., \& Newig, J. (2015). Public participation and local environmental planning: Testing factors influencing decision quality and implementation in four case studies from Germany. Land Use Policy, 46, 211-222. doi: http://dx.doi.org/10.1016/j.landusepol.2015.02.010 
Fanani, A. K. (2017 ). Hutan adat yang kembali ke pangkuan masyarakat. Senin, 9 Januari 2017 Retrieved 22/8/2017, 2017, from http://www.antaranews.com/berita/605551/hutan-adat-yangkembali-ke-pangkuan-masyarakat

FAO. (2017). Sustainable forest management. Natural Forest Management. 2 May 2017. Retrieved 30 September 2017, 2017, from http://www.fao.org/forestry/sfm/en/

FPP, Pusaka, \& Pokker SHK (2014). Securing Forests Securing Rights, Report of the International Workshop on Deforestation and the Rights of Forest Peoples. Palangkaraya: Forest People Programme, Pusaka, and Kelompok Kerja Sistem Hutan Kerakyatan.

Fung, B. (2014). The Demand and Need for Transparency and Disclosure in Corporate Governance. Universal Journal of Management, 2(2), 7280.

Gauset, Q., Kenrick, J., \& Gibb, R. (2011). Indigeneity and autochthony: a couple of false twins? Social Anthropology/Anthropologie Sociale, 19 (2), 135-142. doi: 10.1111/j.1469-8676.2011.00144.x

Gautier, D., Garcia, C., Negi, S., \& Wardell, D. A. (2015). The limits and failures of existing forest governance standards in semi-arid contexts. International Forestry Review, 17(S2), 114-126.

Gbedomon, R. C., Floquet, A., Mongbo, R., Salako, V. K., Fandohan, A. B., Assogbadjo, A. E., \& Glèlè Kakaï, R. (2016). Socio-economic and ecological outcomes of community based forest management: A case study from Tobé-Kpobidon forest in Benin, Western Africa. Forest Policy and Economics, 64(Supplement C), 46-55. doi: https://doi.org/10.1016/j.forpol.2016.01.001

Gooda, M. (2010). Social Justice and Aboriginal and Torres Strait Islander peoples access to services. Paper presented at the QCOSS Regional Conference: Building a Better Future-themed around improving service delivery for regional and remote communities. https://www.humanrights.gov.au/news/speeches/social-justice-andaboriginal-and-torres-strait-islander-peoples-access-services-2010

Grošelj, P., Hodges, D. G., \& Zadnik Stirn, L. (2016). Participatory and multicriteria analysis for forest (ecosystem) management: A case study of Pohorje, Slovenia. Forest Policy and Economics, 71(Supplement C), 80-86. doi: https://doi.org/10.1016/j.forpol.2015.05.006

Grumblies, A.-T. (2013). Being Wana, Becoming an "Indigenous People". Experimenting with Indigeneity in Central Sulawesi. In B. HauserSchäublin (Ed.), Adat and Indigeneity in Indonesia Culture and Entitlements between Heteronomy and Self-Ascription (Vol. 7, pp. 82-98). Göttingen: Göttingen University Press

Grydehøj, A., \& Ou, Z. (2017). Deterritorialization of indigeneity: Indigenous territory, development policy, and the Dan fishing community of 
Hainan (China). Political Geography, 61(Supplement C), 77-87. doi: https://doi.org/10.1016/j.polgeo.2017.07.002

Guidotti, T. L. (2007). Traditional Knowledge: Challenge or Complement to Science? Archives of Environmental \& Occupational Health, 62(4), 167-168. doi: 10.3200/AEOH.62.4.167-168

Hartanto, H., Rangan, H., Thorburn, C., \& Christian, K. (2008). Strategic Engagement and Dynamic Adaption: Customary Forest Management in Kerinci, Central Sumatra, Indonesia. Paper presented at the The 12th Biennial Conference of the International Association for the Study of Commons, Cheltenham, UK.

Henley, D., \& Davidson, J. S. (2007). Introduction: radical conservatism - the protean politics of adat. In J. S. Davidson \& D. Henley (Eds.), The Revival of Tradition in Indonesian, Politics The deployment of adat from colonialism to indigenism (pp. 1-49). New York: Routledge

Heuer, M. (2011). Ecosystem Cross-Sector Collaboration: Conceptualizing an Adaptive Approach to Sustainability Governance. Business Strategy and the Environment, 20(4), 211-221. doi: 10.1002/bse.673

Huntington, H., Callaghan, T., Fox, S., \& Krupnik, I. (2004). Matching traditional and scientific observations to detect environmental change : A discussion on Arctic terrestrial ecosystems. Ambio(13), 18-23.

ITTO. (2017). Sustainable forest management. Retrieved 30 September 2017, 2017, from http://www.itto.int/sustainable_forest_management/

IWGIA. (2016). The Indigenous World 2016 (D. V. a. C. Mikkelsen Ed.). Copenhagen: The International Work Group for Indigenous Affairs.

Johnson, C. (2015). Indonesia: Declaration on Rights of Indigenous People to Forests. 29 April 2015. Retrieved 22 November 2016, 2016, from http://www.loc.gov/law/foreign-news/article/indonesia-declarationon-rights-of-indigenous-people-to-forests/

Jordan, A., Wurzel, R. K. W., \& Zito, A. (2005). The Rise of 'New' Policy Instruments in Comparative Perspective: Has Governance Eclipsed Government? Political Studies, 53(3), 477-496. doi: 10.1111/j.14679248.2005.00540.x

Juanwen, Y., Quanxin, W., \& Jinlong, L. (2012). Understanding indigenous knowledge in sustainable management of natural resources in China: Taking two villages from Guizhou Province as a case. Forest Policy and Economics, 22(0), 47-52. doi: http://dx.doi.org/10.1016/j.forpol.2012.02.012

KATR/BPN. (2015). Tata Cara Penentuan Hak Komunal atas Tanah Masyarakat Hukum Adat dan Masyarakat yang Berada dalam Kawasan Tertentu: Peraturan Menteri Agraria dan Tata Ruang/Kepala Badan Pertanahan Nasional, Nomor 9 Tahun 2015.

KATR/BPN. (2016). Tata Cara Penetapan Hak Komunal atas Tanah Masyarakat Hukum Adat dan Masyarakat yang Berada pada Kawasan 
Tertentu: Peraturan Menteri Agraria dan Tata Ruang/Kepala Badan Pertanahan Nasional Nomor 10 Tahun 2016.

Kawharu, M. (2011). Forestry and indigenous issues: New Zealand and the Pacific. Paper presented at the International Expert Group Meeting Indigenous Peoples and Forests, New York.

KEMENDAGRI (2014). Pedoman Pengakuan dan Perlindungan Masyarakat Hukum Adat: Peraturan Menteri Dalam Negeri Nomor 52 tahun 2014.

KEMENDAGRI, K., PU,BPN ,i. (2014). Tata Cara Penyelesaian Penguasaan Tanah yang Berada di Dalam Kawasan Hutan: Peraturan Bersama Nomor : 79 Tahun 2014, PB.3/Menhut-11/2014, 17/PRT/M/2014, $8 / \mathrm{SKB} / \mathrm{X} / 2014$.

Kementerian Negara Lingkungan Hidup (2014). Pedoman Penentuan Daya Dukung dan Daya Tampung Lingkungan Hidup. Jakarta: Kementerian Negara Lingkungan Hidup Republik Indonesia.

Kementerian PPN/BAPPENAS (2013). Masyarakat Adat di Indonesia: Menuju Perlindungan Sosial yang Inklusif. Jakarta: Direktorat Perlindungan dan Kesejahteraan Masyarakat, Kementeriaan PPN/Bappenas.

Klenke, K. (2013). Whose Adat is it? Adat, Indigeneity and Social Stratification in Toraja. In B. Hauser-Schäublin (Ed.), Adat and Indigeneity in Indonesia Culture and Entitlements between Heteronomy and Self-Ascription (Vol. 7, pp. 149-166). Göttingen: Göttingen University Press

KLHK. (2015a). Hutan Hak: Peraturan Menteri Lingkungan Hidup dan Kehutanan Nomor P.32/Menlhk-Setjen/2015.

KLHK. (2015b). Penanganan Konflik Tenurial Kawasan Hutan: Menteri Lingkungan Hidup dan Kehutanan Nomor P.84/Menlhk-Setjen/2015.

Kothari, A. (2007). Traditional Knowledge and Sustainable Development. Manitoba, Canada: International Institute for Sustainable Development (IISD).

Kuper, A. (2003). The Return of the Native. Current Anthropology, 44 (3), 389-402.

Larson, A. M., Cronkleton, P. J., \& Pulhin, J. M. (2015). Formalizing Indigenous Commons: The Role of 'Authority' in the Formation of Territories in Nicaragua, Bolivia, and the Philippines. World Development, 70(0), 228-238. doi: http://dx.doi.org/10.1016/j.worlddev.2015.02.004

Lesliea, H. M., Basurto, X., Nenadovic, M., Sievanena, L., Kyle C. Cavanaugh, Cota-Nieto, J. J., . . . Aburto-Oropezag, O. (2015). Operationalizing the social-ecological systems framework to assess sustainability. PNAS, 112/19, 5979-5984.

Li, T., xa, \& Murray. (2010). Indigeneity, Capitalism, and the Management of Dispossession. Current Anthropology, 51(3), 385-414. doi: $10.1086 / 651942$ 
Linggasari, Y. (2016). Pengabaian Hak Masyarakat Adat Bisa Berujung Separatisme. 24 Januar 2016y. Retrieved 16 August 2017, from https://www.cnnindonesia.com/nasional/20160124195910-20106337/pengabaian-hak-masyarakat-adat-bisa-berujungseparatisme/

Luz, A., Guèze, M., Paneque-Gálvez, J., Pino, J., Macía, M., Orta-Martínez, M., \& Reyes-García, V. (2015). How Does Cultural Change Affect Indigenous Peoples' Hunting Activity? An Empirical Study Among the Tsimane' in the Bolivian Amazon. Conservation and Society, 13(4), 382-394. doi: 10.4103/0972-4923.179879

Mahkamah Konstitusi Republik Indonesia (2013). Pengujian Undang Undang 41 tahun 1999 tentang Kehutanan (20 Mei 2013 ed.): Putusan Mahkamah Konstutisi Republik Indonesia Nomor 35/PUU-X/2012.

Martinez, D. (2010). The Value of Indigenous Ways of Knowing to Western Science and Environmental Sustainability. The Journal of Sustainability Education.

Mazzocchi, F. (2006). Western science and traditional knowledge: Despite their variations, different forms of knowledge can learn from each other. EMBO Reports, 7(5), 463-466. doi: 10.1038/sj.embor.7400693

McGinnis, M. D., \& Ostrom, E. (2014). Social-ecological system framework: initial changes and continuing challenges. Ecology and Society, 19(2). doi: 10.5751/ES-06387-190230

Miller, L., \& Nadeau, S. (2016). Perceptions of public land governance from two Canadian provinces: How is the social agenda being met through sustainable forest management? Land Use Policy. doi: https://doi.org/10.1016/j.landusepol.2016.10.041

Moeliono, M., \& Dermawan, A. (2006). The Impacts of Decentralization on Tenure and Livelihoods. In C. Barr, I. A. P. Resosudarmo, A. Dermawan, J. F. McCarthy, M. Moeliono \& B. Setiono (Eds.), Decentralization of forest administration in Indonesia: implications for forest sustainability, economic development and community livelihoods (pp. 108-150). Bogor, Indonesia: Center for International Forestry Research (CIFOR)

Mulyoutami, E., Rismawan, R., \& Joshi, L. (2009). Local knowledge and management of simpukng (forest gardens) among the Dayak people in East Kalimantan, Indonesia. Forest Ecology and Management, 257(10), 2054-2061. doi: http://dx.doi.org/10.1016/j.foreco.2009.01.042

Murniati, Padmanaba, M., Basuki, I., \& van der Ploeg, J. (2006). Gunung Lumut biodiversity assessment socio-economic study: how important forest and landscape resource for community living in and around Gunung Lumut protection forest? Final report to TROPENBOS. Bogor, Indonesia: Center for International Forestry Research (CIFOR). 
Muur, W. v. d. (2015). Will customary land rights destroy Indonesia's last remaining forests? Retrieved 25 April 2015, 2015, from http://leidenlawblog.nl/articles/will-customary-land-rights-destroyindonesias-last-remaining-forests

Myers, R., Intarini, D., Sirait, M. T., \& Maryudi, A. (2017). Claiming the forest: Inclusion and exclusion under Indonesia's "new" policy on cutomary forest. Land Use Policy, 66, 205-213.

Nair, M. S. (2006) Defining Indigeneity Situating Transnational Knowledge. In W. S. Foundation (Series Ed.), World Society Focus Paper Series. New Delhi.

Nick. (2014, 22 December 2017). From safeguards to safeguarding: Engaging indigenous peoples and local communities on REDD+. Mapping Environmental Justice. 17 July 2014. Retrieved 31 December 2017, 2017, from http://www.ejolt.org/2014/07/from-safeguards-tosafeguarding-engaging-indigenous-peoples-and-local-communitieson-redd/

Nugroho, H. Y. S. H., van der Veen, A., Skidmore, A. K., \& Hussin, Y. A. (2017). Expansion of traditional land-use and deforestation: a case study of an adat forest in the Kandilo Subwatershed, East Kalimantan, Indonesia. Journal of Forestry Research. doi: 10.1007/s11676-017-0449-9

Osakede, K. O., \& Ijimakinwa, S. O. (2015). Traditional institution and the modern dayadministration of nigeria: Issues and prospects. Journal of Research and Development (RnD), Vol. 2, No. 9.

PSKL. (2016). Tata Cara Verifikasi dan Validasi Hutan Adat. Jakarta: Direkorat Jenderal Perhutanan Sosial dan Kemitraan Lingkungan

Rai, R. K., Dhakal, A., Khadayat, M. S., \& Ranabhat, S. (2017). Is collaborative forest management in Nepal able to provide benefits to distantly located users? Forest Policy and Economics, 83(Supplement C), 156-161. doi: https://doi.org/10.1016/j.forpol.2017.08.004

RAN. (2017). For First Time in History, Indonesian Government Recognizes Indigenous Customary Land Rights; Returns Contested Company Concessions to Local Communities. Press Release. 04 January 2017. Retrieved 18 September 2017, 2017, from https://www.ran.org/for_first_time_in_history_indonesian_governme nt_recognizes_indigenous_customary_land_rights_returns_contested _company_concessions_to_local_communities

Republik Indonesia (1999). Kehutanan: Undang Undang Nomor 41 Tahun 1999

Republik Indonesia (2008). Rencana Tata Ruang Nasional. Jakarta: Peraturan Pemerintah Nomor 26 Tahun 2008

Rhodes, R. A. W. (1996). The New Governance: Governing without Government1. Political Studies, 44(4), 652-667. doi: 10.1111/j.14679248.1996.tb01747.x 
Rives, F., Carrière, S. M., Montagne, P., Aubert, S., \& Sibelet, N. (2013). Forest Management Devolution: Gap Between Technicians' Design and Villagers' Practices in Madagascar. Environmental Management, 52(4), 877-893. doi: 10.1007/s00267-013-0138-1

Rodríguez Bolívar, M. P., Navarro Galera, A., \& Alcaide Muñoz, L. (2015). Governance, transparency and accountability: An international comparison. Journal of Policy Modeling, 37(1), 136-174. doi: http://dx.doi.org/10.1016/j.jpolmod.2015.01.010

Royer, S. D., Visser, L. E., Galudra, G., Pradhan, U., \& Noordwijk, M. V. (2015). Self-identification of indigenous people in postindependence Indonesia: a historical analysis in the context of REDD+. International Forestry Review Vol.17(3).

Rye, S. A., \& Kurniawan, N. I. (2017). Claiming indigenous rights through participatory mapping and the making of citizenship. Political Geography, 61(Supplement C), 148-159. doi: https://doi.org/10.1016/j.polgeo.2017.08.008

Samho, B., \& Purwadi, Y. S. (2016). Perubahan Pola Pikir Masyarakat Adat Dayak di Kabupaten Sanggau terhadap Hutan Adat Sebagai Akibat Perkebunan Kelapa Sawit (Vol. Perjanjian No: III/LPPM/2016-02/115P). Bandung: Lembaga Penelitian dan Pengabdian kepada Masyarakat, Universitas Parahyangan.

Sasaoka, M., \& Laumonier, Y. (2012). Suitability of Local Resource Management Practices Based on Supernatural Enforcement Mechanisms in the Local Social-cultural Context. Ecology and Society, 17(4). doi: 10.5751/ES-05124-170406

Sherpa, L. N., \& Sinogba, E. (2016). Sustainable forest management ties indigenous group together against eviction threats. Case study of the ILC Database of Good Practices. Rome, Italy: International Land Coalition.

Siscawati, M., Banjade, M. R., Liswanti, N., Herawati, T., Mwangi, E., Wulandari, C., . . S Silaya, T. (2017) Overview of forest tenure reforms in Indonesia. Vol. Working Paper 223 (pp. 36). Bogor, Indonesia: Centre for International Forestry Research (CIFOR).

Snively, G., \& Corsiglia, J. (2001). Discovering indigenous science: Implications for science education. Science Education, 85(1), 6-34. doi: 10.1002/1098-237X(200101)85:1<6::AID-SCE3>3.0.CO;2-R

Stason, E. B. (1941). "Substantial Evidence" in Administrative Law. University of Pennsylvania Law Review and American Law Register, 89(8), 10261051. doi: $10.2307 / 3309074$

Tropenbos International Indonesia (2006). Penilaian Ekonomi Sumberdaya Hutan Lindung Gunung Lumut, Kabupaten Paser, Kalimantan Timur (Vol. TE-06/TBI Indonesia/05-I). Bogor, Indonesia: Tropenbos International Indonesia dan Greenomics Indonesia. 
Tsing, A. (2002). Indigenous Voice. In M. D. L. Cadena \& O. Starn (Eds.), Indigenous Experience Today (pp. 33-68). Oxford, UK: Berg, Oxford International Publishers

Tyson, A. D. (2010). Decentralization and adat revivalism in Indonesia: The politics of becoming indigenous.

UN. (2009). State of the World's Indigenous Peoples (Vol. ST/ESA/328). New York: Secretariat of the Permanent Forum on Indigenous Issues, Division for Social Policy and Development, Department of Economic and Social Affairs, The UN.

UNEP. (2011). Emerging Perspectives on Forest Biodiversity UNEP Year Book 2011: United Nations Environment Programme

UNEP. (2012). Deforestation Costing Kenyan Economy Millions of Dollars Each Year and Increasing Water Shortage Risk. 5 November 2012. Retrieved 13 May, 2013, from http://www.unep.org/Documents.Multilingual/Default.asp?DocumentI $D=2698$ \&ArticleID $=9316 \& \mathrm{I}=$ en

UNHR. (2013) Indigenous Peoples and the United Nations Human Rights System. Vol. Fact Sheet No. 9/Rev.2. New York and Geneva: United Nations Human Rights, Office of The High Commisioner.

United Nations (2008). United Nations Declaration on the Rights of Indigenous Peoples: United Nations.

Wachira, G. M. (2010). Applying Indigenous Peoples' Customary Law in Order to Protect their Land Rights in Africa. In G. Rose \& J. Dahl (Eds.), Development and Customary Law (pp. 6-15). Copenhagen, Denmark: International Work Group for Indigenous Affairs

Wahyuni, T. (2011). Can traditional forest management protect and conserve ironwood (ulin) stands? An option and approach in East Kalimantan. (Doctor), University of Leiden, Leiden, The Netherlands.

Zakaria, Y. (2017, 10 February 2017). After the customary forest recognition. 26 January 2017. Retrieved 10 February 2017, 2017, from http://www.thejakartapost.com/academia/2017/01/26/after-thecustomary-forest-recognition.html 


\section{CHAPTER 2}

\section{THEORETICAL FRAMEWORK FOR SPATIAL PLANNING AND FOREST MANAGEMENT IN INDONESIA: SECURING THE BASIC RIGHT OF ADAT PEOPLE 1}

1 This chapter is based on:

Nugroho, H. Y. S. H., van der Veen, A., Skidmore, A., \& Hussin, Y. A. (2017).

Theoretical Framework For Spatial Planning And Forest Management In Indonesia: Securing The Basic Rights For ADAT People. Indonesian Journal of Forestry Research 4(1), 15. doi: $10.20886 /$ ijfr.2017.4.1.69-83 


\begin{abstract}
Limited transparency, accountability, and participation in policy formulation as well as implementation mainly based on economic considerations, all lead to failure to attain sustainable forest management (SFM). Along with the reluctance of policy makers and lacking stakeholder capacity, less accurate data bases has also indicated a constraint in the development of appropriate action. The issues have been more complicated where they were correlated with economic imperatives, vested interest, ownership issues and the basic rights of indigenous communities living inside or adjacent the forest. Forest destruction will be no end without securing customary land and territorial rights. To cope with these issues, the concept of fair governance has been promoted as an alternative to the traditional pattern of administration. In this paper, we propose a theoretical framework for policy development in order to attain SFM while respecting the rights of the ADAT people. We show that adaptive governance, adaptive management, and participatory learning are strategic approaches in governance reform to achieve sustainable forest management securing the customary rights and traditional land use of forest dependent people.
\end{abstract}

Keywords: Forest management, adaptive governance, spatial planning, Indonesia, ADAT

\title{
2.1 Introduction
}

Issues related to deforestation, land degradation, and disharmony between stakeholders, have formed an ongoing theme in many international forestrelated workshops, scientific journals and publications for more than three decades. This interest is motivated by significant global deforestation and its effect on government revenue, environmental degradation, and the livelihood opportunities of forest-dependent people (Boafo, 2013; UNEP, 2011, 2012). Empirical data across countries show that a main cause of forest destruction and conflict among stakeholders is weak governance, which is characterized by limited transparency, accountability, and participation (Carothers \& Brechenmacher, 2014; Drazkiewicz, Challies, \& Newig, 2015; Rodríguez Bolívar, Navarro Galera, \& Alcaide Muñoz, 2015). The term governance is used to label a process marking a decreasing role for the government and an increasing role for others in public service provision, addressing social as well as economic considerations at the same times in a balanced way (Rhodes, 1996).

Although concerns related to weak forest governance did receive attention invarious international forums, there is still limited knowledge about the effecton deforestation, degradation, and livelihoods at local levels, as well as how to address this issue to attain sustainable forest management (Blaser, 
2010). The issues have been more problematic when they correlate with ownership issues, territory, and the basic right of indigenous community. For many indigenous peoples, the forest plays essential roles in ensuring their cultural, spiritual and different ways of economic well being (Marwa et al., 2010; Kawharu, 2011; Roslinda et al., 2012). The term of indigenous peoples in Indonesia is associated with some different terminology such as native people, isolated people and ADAT communities or ADAT law communities. The Ministry of Social Affairs identifies some indigenous communities as komunitas ADAT terpencil (geographically-isolated indigenous communities) (IWGIA, 2016). However, many more peoples self-identify or are considered by others as indigenous. Recent laws and regulations use the term masyarakat ADAT to refer to indigenous peoples, including Law No. 5/1960 on Basic Agrarian Law, Law No. 39/1999 on Human Rights, Law No. 27/2007 on Management of Coastal and Small Islands and Law No. 32/2009 on Environment Protection and Management. Law No. 32/2009 on Environment Protection and Management, article 1 point 31 define ADAT law community as a community group hereditary living in certain geographic areas based on the ancestral bond, the strong relationship with the environment, and the existence of value system determining economic, political, social, and legal institutions.

In Indonesia, a country with more than 1300 ethnic groups and more than 2500 languages (BPS, 2010). issues related to indigenous people and customary right have been considered as intriguing issues for many years and widely increased since the regional autonomy era (Banjade, Herawati, Liswanti, \& Mwangi, 2016; Royer, Visser, Galudra, Pradhan, \& Noordwijk, 2015). Most of the indigenous community territories are located within forest areas. According to AMAN (Aliansi Masyarakat ADAT Nusantara/ Indigenous Peoples' Alliance of the Archipelago), 90 percent of at least 84 million ha of ADAT communities' territories are forest (Zakaria, 2017). In many cases, ADAT people who lived on (state) forest for generations before the issuance of Forestry law are accused as forest encroachers (Hartanto, Rangan, Thorburn, \& Kull, 2008; Wijaya, 2014). This accusation leads to conflict in almost every Indonesian region (IWGIA, 2011; Wijaya, 2014). Currently, there are 33 thousand villages in and adjacent to forest areas with a conflict, and without legal certainty (Tambunan, 2012).

The Spatial Planning Law No. 26/2007 and the Government Regulation of National Spatial Plan 26 (2008), stipulated that the ADAT community has a legal position to affect spatial planning policy particularly the spatial policy of the forest. However, involving the ADAT community in spatial planning process is not an easy process. ADAT rights normatively are acknowledged but in practice they are not properly accommodated in land use planning processes. The recognition of usufruct right of indigenous people, -the right 
to derived benefits from the forest and forest land without any damage on the forest function as stated in forestry-related statutes has not yet been translated in practical regulation (Kusumanto, 2007; Nizar, 2010; Raharjo, 2014). Meanwhile, as community groups with a large population depending on forest resources, ADAT communities are at an increased threat from land use change impact, global deforestation and environment degradation.

In the International Workshop on Deforestation and the Rights of Forest Peoples held in Palangkaraya, Indonesia March 2014, delegates agreed that forest destruction will be no end without securing forest peoples' land and territorial rights. Measures must also be taken at all levels to ensure full participation of indigenous people, who inhabit, use, have customary rights to, and rely on forests for their identity and survival as a key stakeholder in decision-making.

Concerning to above mentioned issues, this paper proposes a concept for the reform of forest-based spatial planning respecting the basic rights of the ADAT people, covering policy making as well as a way to introduce policy reform. The main focus is the design of a practical mechanism incorporating decision support systems, based on the answers to the following questions: (1) How to move from normative to measurable policies? (2) How to incorporate resources, needs, power, and knowledge? (3) How to formulate appropriate tools and mechanisms, involving all key stakeholders in spatial planning policy formulation, implementation, and monitoring?

\subsection{Material and Method}

This paper is written basically based on series of literature studies consisting of series of activities from finding, reviewing and evaluating relevant material, and synthesizing information. This paper develop its arguments from extracting existing legal frameworks and other related policies, journals, textbooks and publications concerning spatial planning, forest management, governance, indigenous community, and ADAT. The narratives of spatial planning and forest management incorporating ADAT rights is viewed using a theoretical framework in the context of an appropriate spatial planning governance. A theoretical framework consists of concepts and existing theory that is used for a particular study. The theoretical framework demonstrates an understanding of theories and concepts that are relevant to the topic and that relate to the broader areas of knowledge being considered (McGinnis \& Ostrom, 2014).The selection of a theory depend on its appropriateness, ease of application, and explanatory power.

The paper is structured in the following sections; the section one examines the weaknesses of traditional governance and the issues of ADAT peoples in 
Indonesia. The second section discusses differences between traditional administration versus modern governance. The third section depicts the history of spatial planning, forest governance, and ADAT rights in Indonesia. The fourth section explain theoretical framework toward a solution, and the last section is concluding remarks.

\subsection{Result and Discussion}

\subsubsection{Administrative Reforms: Traditional versus Modern}

In the past two decades, many countries have been trying to formulate appropriate development policies to attain sustainable solutions, moving from conventional centralized development policies to a decentralized approach with increasing involvement of stakeholders (Faguet, 2014; Faludi, 2009; Yazdi, 2013). This new direction is in line with the growing awareness of the interrelationships between social-economic and ecological systems (Ekayani et al., 2014; Fabiny et al., 2014; Lesliea et al., 2015; McGinnis \& Ostrom, 2014).

In Indonesia, an archipelagic country with a republican system of government consisting of more than five hundred autonomous regions, inhabited by more than 240 million people from more than 1,300 tribes, and spread out over 6,000 inhabited islands, administrative reforms are essential. It is not a simple concept, but should be managed in a systematic way, from problem identification, policy formulation, and implementation, to monitoring and evaluation, while being highly influenced by stakeholders. Table 2.1 indicates the main differences between traditional administration and modern governance are summarized.

Tabel 2. 1. Differences between traditional administration and modern governance

\begin{tabular}{|c|c|c|c|}
\hline Parameters & $\begin{array}{c}\text { Traditional } \\
\text { administration }\end{array}$ & $\begin{array}{c}\text { Modern } \\
\text { Governance }\end{array}$ & Literature \\
\hline Dominant Players & Central government & $\begin{array}{l}\text { Multi-player, multi- } \\
\text { level }\end{array}$ & $\begin{array}{l}\text { (Ardanaz et al., 2014; } \\
\text { Bressers \& Kuks, 2003; } \\
\text { Heuer, 2011; Jordan et } \\
\text { al., 2005) }\end{array}$ \\
\hline $\begin{array}{l}\text { Policy } \\
\text { development } \\
\text { process }\end{array}$ & $\begin{array}{l}\text { Centralistic; direct } \\
\text { central governmental } \\
\text { action, top down, } \\
\text { minimal integration, } \\
\text { strict command and } \\
\text { control }\end{array}$ & $\begin{array}{l}\text { Social } \\
\text { humanitarian; } \\
\text { socio-cybernetic } \\
\text { system, self- } \\
\text { organizing } \\
\text { network, } \\
\text { transparent, } \\
\text { accountable, } \\
\text { adaptive, and } \\
\text { flexible }\end{array}$ & $\begin{array}{l}\text { (Ardanaz et al., 2014; } \\
\text { Cimpoeru \& Cimpoeru, } \\
\text { 2015; Drazkiewicz et } \\
\text { al., 2015; Fung, 2014; } \\
\text { Jordan et al., 2005; } \\
\text { Osakede \& Ijimakinwa, } \\
\text { 2015; Rhodes, 1996; } \\
\text { Rodríguez Bolívar et al., } \\
\text { 2015) }\end{array}$ \\
\hline Driving factors & Economic & $\begin{array}{l}\text { Social-ecological } \\
\text { and economic }\end{array}$ & $\begin{array}{l}\text { (Jordan et al., 2005; } \\
\text { Lesliea et al., 2015; } \\
\text { McGinnis \& Ostrom, } \\
\text { 2014; Rhodes, 1996) }\end{array}$ \\
\hline
\end{tabular}




\subsubsection{Spatial Planning, Forest Governance and ADAT Rights in Indonesia}

The turning point in the Indonesian political system from a highly centralized government to a new era of decentralization came in 1998, at the time of the resignation of President Suharto, the leader of the New Order regime. Since that year, there has been a gradual political power devolution from central to local government, in accordance with a reformation era. Expectations regarding the potential outcome of decentralization and power devolution were high. In fact, implementation of decentralization occurred much faster than the legal formal process (Moeliono \& Dermawan, 2006). However, in forest management, reality did not match the expectations. Deforestation continued (Suwarno, Hein, \& Sumarga, 2015), and the frequency of forestrelated conflicts increased dramatically during the early implementation of authority decentralization (Nurrochmat, 2005; Wulan et al., 2004). The decentralization process, particularly in forest administration, was planned and implemented poorly (Barr et al., 2006; Hadiz, 2004). Local community interests were not properly accommodated in the land use planning processes (Kusumanto, 2007; Moeliono \& Dermawan, 2006).

\section{a. Spatial Planning and Forest Governance}

The history of Indonesian forest related spatial planning dates from 1982, when the Ministry of Home Affairs formally requested the Ministry of Forestry (MOF) to create Consensus-Based Forest Land Use Planning or Tata Guna Hutan Kesepakatan (TGHK). Two years later, in 1984, the MOF produced TGHK maps, classifying forests as (1) protection forest, i.e., for watershed protection; (2) conservation forest, i.e., as national park or other protected area; (3) limited production forest, where timber harvesting needs protective measures to avoid soil erosion; (4) production forest, for timber harvesting; and (5) conversion forest, for conversion to agriculture, plantation crops, settlements, or other uses.

In October 1992, the central government enacted the first Indonesian law regulating spatial planning. Law No. 24 of 1992 on spatial planning forced the central government to delegate planning authorization to local governments and encouraged public participation. In this law, spatial planning was defined as a process of space planning, space utilization, and control over space utilization. This spatial planning law stipulated the principles of the spatial planning which included integrity, sustainability, effectiveness, efficiency, compatibility, harmony, openness, equality, justice, and legal protection. In accordance with the issuance of the new law, the MoF produced new integrated maps that merged the TGHK maps with the spatial plans of the new provincial and district planning agencies. Milestones of decentralization and devolution in Indonesia were the issuances of Law No. 22 of 1999 on 
Regional Governance and Law No. 25 of 1999 on Fiscal Balancing between the Central and Regional Governments (Ardiansyah \& Jotzo, 2013; Bennet, 2010). Under Law No. 22 and 25 of 1999, central government gave autonomous regions the opportunity to manage local resources directly (Fadli, 2014). In the forestry sector, the government issued Forestry Law No. 41 of 1999, replacing Basic Forestry Law No. 5 of 1967. In 2004, Laws No. 22 and 25 of 1999 were replaced by Laws No. 32 and 33 of 2004, respectively.

Following the institutional reforms, in April 2007, Law No. 26 of 2007 on Spatial Planning was promulgated, replacing Law No. 24 of 1992. The law provides more detailed regulations than the previous spatial planning law including rights, obligations and the forms of public participation in spatial planning. The new law contained some provisions that were not included in the previous one. The new law provides greater authority to local governments in the implementation, supervision, and control of spatial planning. The new law also emphasizes the importance of public participation in spatial planning, providing more detailed regulations regarding rights, obligations, and forms of public participation.

In reality, policy devolution and integration were not implemented and envisioned. Local governments only played a limited role, and participation was a concept rather than being implemented (Bennet, 2010). Two decades of reform and devolution of political power did not result in effective sustainable forest management. On the contrary, deforestation has been accelerated in line with the increasing trend of administrative fragmentation. From 1999 to 2010, 205 new administrative regions have separated from their former administrative jurisdictions. Unfortunately, of all 524 autonomous regions, 199 regions (provinces and districts) are partially situated in forest areas (Komisi Pemberantasan Korupsi, 2010).

\section{b. ADAT Rights}

There are a few policies that regulate the rights of local communities to the land, but the recognition of people's customary territory is still limited (Johnson, 2015). Recognition of the rights of ADAT or customary rights in Indonesian law commenced five decades ago appears in the Law No. 5 of 1960 concerning Basic Agrarian that accommodate recognition of ADAT communities, ulayat land rights, and ADAT laws. A definition of ADAT community is stated in Law No. 32 of 2009 on Environment Protection and Management. The Law defines an ADAT community as a community group traditionally living in a certain geographic area, based on ancestral bonds, a strong relationship with the environment, and the existence of a value system determining economic, political, social, and legal institutions (Republik Indonesia, 2009a). Forestry Law No. 41 of 1999 and government 
regulation number 26 of 2008 concerning National Spatial Planning normatively regulate that ADAT people have certain rights regarding utilization/cultivation of forest areas: to collect forest products (usufruct) for their daily needs and to carry out forest management practices according to customary laws as long as these are not in conflict with the formal legislation (Republik Indonesia 1999).

In fact, many ADAT communities in Indonesia have little tenure security for lands they have been living on, managing, or cultivating for generations (Moniaga, 2009). Since the new era of decentralization (1999), there were many hopes that the democratisation process would open up opportunities for formal recognition of customary land rights. Yet, the government continues to consider many ADAT lands as state domain, state forest areas. Forestry Law No. 41 of 1999 stated that "customary forests are state forests located in the areas of custom-based communities".

As a response to a petition submitted by the Indigenous Peoples, in May 2013, Indonesia's Constitutional Court issued a decision on the Judicial Review of some parts of Act No. 41/1999 on Forestry. In the decision No. 35/PUU-X/2012, the Constitutional Court confirmed that Customary Forests are forests located in Indigenous territories, and should no longer be considered as State Forests.

Yet despite these important events, indigenous peoples in Indonesia continue to face conflicts of territory, land and natural resources (AMAN, 2014). The recognition of indigenous claims is still a complicated and sensitive issue.

The challenge is how to balance functionbased sustainable forests and livelihood security of forest dependent people/ADAT communities. Since spatial conflicts involving local people communities have been a latent problem, holistic knowledge of the ecological system combined with a clear understanding of the social economic and cultural dynamics of the community is essential (Bryan et al., 2010; Ryan, 2011). The approach should pay attention to the issues related to certainty of land tenure and the basic rights of local people, and promote transparent and participatory processes in decision making.

\subsubsection{Theoretical Framework Towards a Solution}

Even in developed countries, spatial conflicts usually emerge where economic concerns and conservation benefits clash. Laws governing development and those governing conservation are often in conflict (Garmestani et al., 2008). Decentralization itself cannot guarantee the success of attaining sustainable 
forest management and securing the livelihood of local people (Angelsen, 2009; Ardiansyah \& Jotzo, 2013; Suwarno et al., 2015).

We recommend two interrelated factors as a prerequisite of good quality forest-based spatial planning for achieving Sustainable Forest Management considering ADAT rights:

a. Availability of an appropriate institution to formulate forest-based spatial planning law based on various resource, needs, and knowledge of multi stakeholders

b. Availability of appropriate mechanisms and tools to formulate sustainable forest management technologies based on comprehensive and accurate data and information.

\subsubsection{Determining Appropriate Institutions}

Environmental governance is not only a matter of regulation and law enforcement, as the more important aspect is development of a framework for coordinating and controlling multiple stakeholders with multiple interests (Cronkleton et al., 2008; Drazkiewicz et al., 2015; UNEP, 2013) and synergizing their various resources, power, need and knowledge (Frost, Campbell, Medina, \& Usongo, 2006; UNEP, 2013).

Determining appropriate institutions can be conducted in a systematic way by firstly assessing the existing and then the ideal conditions for a spatial planning process in terms of rules, structures and stakeholders involved. In our view, this systematic assessment should be based on data or information, which is generated from the perspectives of all stakeholders.

The key parameters in assessing the existing rules and structures (i.e. the process of policy formulation, interpretation, and implementation) of spatial planning are transparency of the political process, effectiveness of the policy instruments applied, economic efficiency of the use of resources, and legitimacy in line with democracy (Florini, 1999; Lindstedt \& Naurin, 2010). This depends on whether the interest and the involvement of all stakeholders are consistent or not with the position, interest, and legitimacy they have. Referring to Schmeer (1999), stakeholder positions are related to whether stakeholders support, oppose or are neutral about the policy. Stakeholder interest is related to the advantages or disadvantages of the implementation of a policy for each involved party. Stakeholder importance is related to the capacity of stakeholders to interfere in the process of policy implementation (Schmeer, 1999). Meanwhile, in this case, legitimacy refers to public admission (formal or informal) regarding the right and authority of each stakeholder. 
In Figure 2.1 we depict the process of improving appropriate institutions to fill the gap between the actual and the ideal as an important part of governance reform.

\subsubsection{Synergizing Resources, Needs and Knowledge for Policy Formulation}

As mentioned above, an important aspect of governance is the development of an effective mechanism for coordinating and controlling stakeholders with multiple interests. There must be clear roles and connections among stakeholders in synergizing resources, needs and knowledge for policy formulation. Holistic knowledge of the ecological system combined with a clear understanding of the social economic and cultural dynamics of the community at various levels is essential to improve the quality and effectiveness of an environmental policy (Bryan et al., 2010; Huber et al., 2013; Lesliea et al., 2015; Ryan, 2011). Thus, institutional activities are not only to assemble multi perspectives, needs and interest of stakeholders but also to develop a conducive environment and a better mechanism for data or information sharing. In the case of Indonesia Forestry, there are many stakeholders (either private or governmental institutions) responsible for producing data, but in reality the data produced are sometimes inaccurate, inaccessible, or do not match or are not suitable for certain needs in terms of their format and scale (temporal and spatial). 


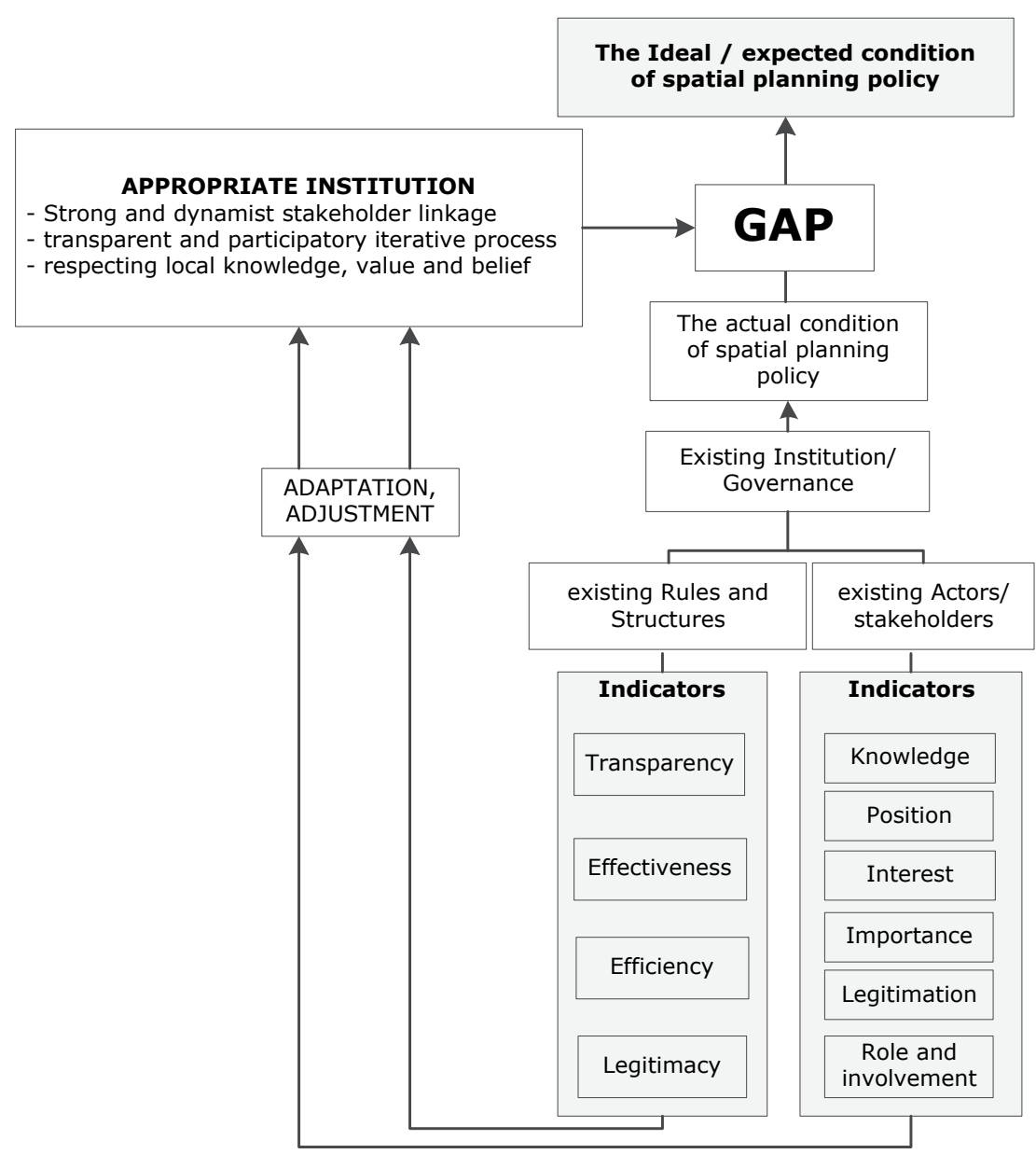

Figure 2. 1. Framework of appropriate institution determination

The critical point, however, is to ensure that the whole process will flow. A major challenge is thus to present stakeholders at all levels with knowledge and learning capabilities. ADAT people or civil societies should be involved in the whole policy process, from upstream to downstream. Since local people and the forest inhabitants can be either potential agents for achieving a sustainable outcome or a potential agent of disorder, activating and placing them in an appropriate role and position determines the flow of the whole mechanism.

\subsubsection{Determining Appropriate Tools and Mechanisms for Policy} Formulation: from Normative Into Measurable Policies

Forestry Law No. 41 of 1999 regulates that ADAT forest utilization by the ADAT community must be in accordance with the forest function. Utilization 
by the ADAT community is acceptable as long as it does not disturb this function. Similar to the Forestry Law, Government Regulation No. 26 of 2008 on National Spatial Planning, regulates that native people have the right to utilize or cultivate forest areas as long as there is no damage to the functions and under strict supervision. All regulation is however normative. In general, regulations are developed based on standards and guidelines or opinions of policy maker and do not take into account scientific principles which are actual, objective and testable. The problems thus are: how to implement the regulation; how to translate the regulation into a lower order and more practical regulation, such as technical guidance of site management; how to enable local people or the gain direct or indirect income without breaking the rules?

For spatial planning in a forested region where the traditional community is a main stakeholder, an important aspect of management is to define a tool or mechanism that translates the rules into 'easily understood' technical language. The tool or mechanism should be able to explain the benefits and risks of each interpretation and implementation of each policy.

Using research findings as evidence, development policy is to be formulated as a combination of Spatial Decision Support Systems (DSS) and the process of "learning by doing". The process of "learning by doing" is a combination of a collaborative and systemic learning and a knowledge developing process (Eksva"rd \& Rydberg, 2010). In Figure 2.2, we present a conceptual framework of policy formulation adopting the principles of adaptive management and participatory learning. All processes are conducted in a participatory manner, involve key stakeholders, and start with objective formulation, guiding the process of achieving objectives into policy through adaptive procedures. A DSS helps decision makers to define the right alternative based on different scenarios, by combining the benefits of GIS, expert systems, and model simulations (Prasad, Strzepek, \& Kopen, 2004). Meanwhile, participation is employed to enable local people as well as other stakeholders (e.g. local government, NGOs, investors) to witness the consequences of undertaking certain activities or not, and to learn from the real process.

By using the policy formulation process as mentioned above, the need to secure basic ADAT rights in balance with the need to attain sustainable forest management can be accommodated and tested transparently and scientifically. Using spatial modeling, the correlation between actual conditions, policy formulation process, formulated policies, and potential impact after implementation can be traced. The most suitable land for ADAT people and the best management practice for traditional landuse, (technically applicable, economically feasible, socially acceptable, and ecologically 
suitable) with efficient input, high yield, and low negative impact on the forest landscape can thus be determined and designed.

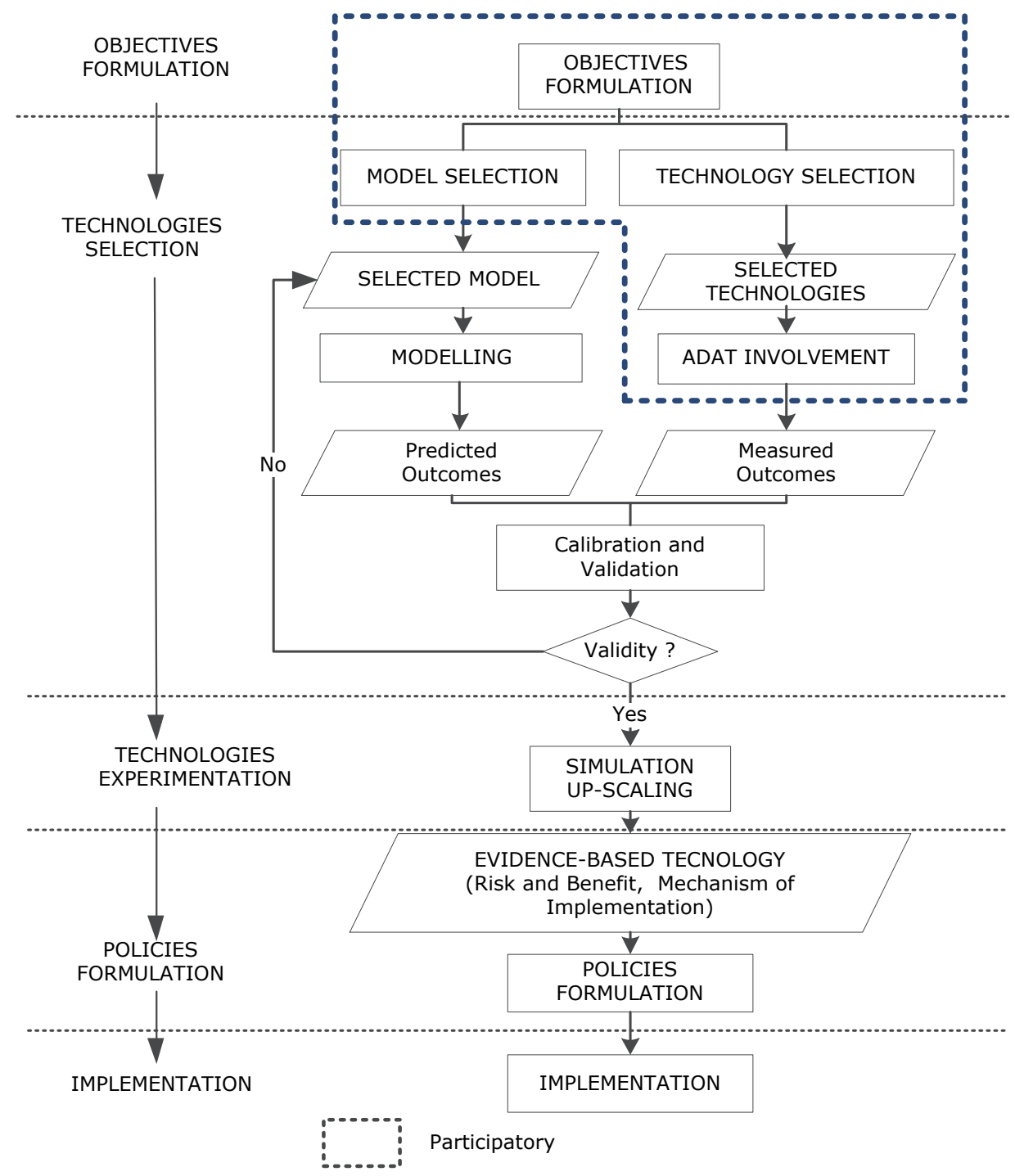

Figure 2.2. Framework for formulation of adaptive management technology

\subsubsection{Application Prerequisites}

As we mentioned above, the important factors of good forest-based spatial planning are the availability of appropriate institutions, the availability of holistic and accurate data and information and availability of appropriate mechanisms and tools to formulate adaptive management technologies. For Indonesia, as a quite young democratic country, the challenges are 
accessibility and availability to data or information, low quality of stakeholders' capacity, and political resistance. For almost all local governments, data and information are rather scarce and expensive.

The capacity of stakeholders involved in the process is seen here as a critical issue. Thus, building capacity and raising willingness of stakeholders responsible for policy formulation, interpretation, and implementation is essential.

Another hindrance is the mentality of certain individuals in local government. Their resistance blocks access to new mechanisms or approaches promoting transparency (Bellver \& Kaufmann, 2005; Florini, 1999). In some cases, transparency has been avoided deliberately. There is an inverse relationship between transparency in governance and opportunities for corruption. Transparent decision making will increase the probability that corruption is detected (Cimpoeru \& Cimpoeru, 2015; Peisakhin, 2012; Takim et al., 2013).

Related to the effort to increase local people participation, a transparent policy process is thus a key factor. People will only participate when there is trust. It is impossible to gain the trust of citizens without providing transparent factual information (Grimmelikhuijsen, 2012; Hasan, 2013). Transparency will not only increase efficiency in resource allocation, but will also make an equitable distribution of benefits possible (Bellver \& Kaufmann, 2005; The Union for Ethical Bio Trade, 2013).

Another fundamental prerequisite for adaptive governance and management is the learning capability and willingness of stakeholders to move out of their 'comfort zone'. Two problems that will be encountered are defensiveness and the ego of actors. Defensive attitudes resulting from defensive reasoning will block any real change.

Learning therefore not only contains a technical aspect but also a moralbehavioral one. Kolb (1984) promotes experiential learning, where he considers experience as a source of learning. Learning is the continuous process of human adaptation to create knowledge as a transformation of experiences. To motivate local communities and to promote a dedicated approach to landscape management, a participatory learning approach (PLA) as an effort to involve communities in formulating and evaluating a problem and its solutions (Bottomley \& Denny, 2011), should be employed.

\subsection{Conclusion}

Failure of the previous classical spatial planning governance may be caused by the dominance of an interest group indifferent to open policy alternatives. 
Adaptive governance is a precondition for interaction between societal actors in participatory decision making by involving parties at multiple levels and multiple scales to support ecosystem management (Heuer, 2011; Loorbach, 2007). The governance process needs to assure that there will be equal opportunity for all stakeholders to benefit from the process. Thus, for agreement in governing, future interaction among stakeholders is a necessity.

We recommend two interrelated factors as a prerequisite of good quality forest-based spatial planning for achieving sustainable forest management considering ADAT rights: 1) Availability of an appropriate institution to formulate forest-based spatial planning law based on various resource, needs, and knowledge of multi stakeholders, and 2) Availability of appropriate mechanisms and tools to formulate sustainable forest management technologies based on comprehensive and accurate data and information.

We recommend that national policymakers allow flexibility in spatial planning policy implementation but develop mechanisms of accountability and control between local and central authorities. The quality of decision making can be improved if decision makers are aware of the implications of their actions (Krott, 2005; Nurrochmat et al., 2016; Ekayani et al., 2016).

Since information forms an essential factor in the formulation of future policies and the analysis of possible outcomes, the process of collecting and analyzing data must be conducted systematically and precisely. The quality of information reflects the accountability as a base for legitimacy. Public awareness and participation will not be attained unless they have access to information on what they will gain, and the risks and benefits of their involvement. Since the DSS is a computer-based mechanism of policy making, monitoring as a means of evaluation and control in this policy system is no longer difficult. The information concerning reasons behind a particular policy and the potential risks and benefits of a certain policy can be accessed through information technology (IT) systems. Again, the supporting effort to make all systems work is increasing the capacity and willingness of all actors responsible in policy formulation, interpretation, and implementation.

\section{Acknowledgement}

This work was prepared based upon collaborative research project between Forestry Research and Development Agency, Tropenbos International Indonesia Program, ITC, and Mulawarman University in East Kalimantan 2008-2012 entitled "Integrating Customary Right and Traditional Land Use 
into Spatial Planning: The Use of Appropriate Modelling for Decision Support Systems". No PIS. 50100020.

\section{References}

AMAN. (2014). 2013 in review indigenous peoples' alliance of the archipelago 28 February 2014. Retrieved 22 November 2016, 2016, from http://www.aman.or.id/2014/02/28/2013-in-review-indigenouspeoples-alliance-ofthe-archipelago-aliansi-masyarakat-ADATnusantaraaman/at 22 November 2016.

Angelsen, A. (2009). Policy options to reduce deforestation. In A. Angelsen (Ed.), Realising REDD+ : National strategy and policy options (pp.125138). Bogor: Center for International Forestry Research.

Ardanaz, M., Leiras, M., \& Tommasi, M. (2014). The politics of federalism in Argentina and its implications for governance and accountability. World Development, 53, 26-45. doi: 10.1016/j.worlddev.2013.01.004

Ardiansyah, F., \& Jotzo, F. (2013). Decentralization and avoiding deforestation the case of Indonesia. In S. Howes \& M. G. Rao (Eds.), Federal reform strategies: Lessons from Asia and Australia (pp. 273300). Oxford, UK: Oxford Unversity Press.

Banjade, M. R., Herawati, T., Liswanti, N., \& Mwangi, E. (2016) Tenure reform in Indonesia, When? What? Why?, Info Brief: Vol. 163 (December 2016 ed.). Bogor: CIFOR.

Barr, C., Resosudarmo, I. A. P., Dermawan, A.,\& Setiono, B. (2006). Decentralization's effects on forest concessions and timber production. In C. Barr, I. A. P. Resosudarmo, A. Dermawan, J. McCarthy, M. Moeliono \& B. Setiono (Eds.), Decentralization of forest administration in Indonesia : Implications for forest sustainability, economic development and community livelihoods (pp. 87-107). Bogor: CIFOR.

Bellver, A., \& Kaufmann, D. (2005). 'Transparenting transparency' initial empirics and policy applications. Paper presented at the IMF conference on transparency and integrity.

Bennet, R. (2010) Decentralizing authority in post-Suharto Indonesia: The big bang theory, 1998-2010. Innovations for Successful Societies. New Jersey, USA: Princenton University.

Blaser, J. (2010). Forest law compliance and governance in tropical countries, A regionby-region assessment of the status of forest law compliance and governance, and recommendations for improvement. In A. Sarre (Ed.), (pp. 1-28): FAO and ITTO.

Boafo, J. (2013). The impact of deforestation on forest livelihoods in Ghana. Retrieved

from http://www. africaportal.org/sites/default/files/Africa\%20Portal\%20Back grounder\%20 No.\%2049.pdf 
Bottomley, S., \& Denny, P. (2011). A participatory learning approach to biochemistry using student authored and evaluated multiplechoice questions. Biochemistry and Molecular Biology Education, 39(5), 352361. doi: $10.1002 / \mathrm{bmb} .20526$

BPS. (2010). Kewarganegaraan, suku bangsa, agama, dan bahasa sehari-hari penduduk Indonesia, Hasil sensus penduduk 2010. Jakarta: Subdirektorat Statistik Demografi, Badan Pusat Statistik.

Bressers, H. T. A., \& Kuks, S. M. M. (2003). What does governance mean? From conception to elaboration. In H. T. A. Bressers \& W. A. Rosenbaum (Eds.), Achieving sustainable development: The challenge of governance across social scales (pp. 43-64.). Westport Connecticut: Praeger Publishers.

Bryan, B. A., Raymond, C. M., Crossman, N. D., \& Macdonald, D. H. (2010). Targeting the management of ecosystem services based on social values: Where, what, and how? Landscape and Urban Planning, 97(2), 111-122. doi: 10.1016/j.landurbplan.2010.05.002

Carothers, T., \& Brechenmacher, S. (2014). Accountability, transparency, participation, and inclusion, a new development consensus? Washington DC: Carnegie Endowment for International Peace.

Cimpoeru, M. V., \& Cimpoeru, V. (2015). Budgetary transparency - an improving factor for corruption control and economic performance. Procedia Economics and Finance, 27, 579-586. doi: 10.1016/S22125671(15)01036-9

Cronkleton, P., Taylor, P. L., Barry, D., Stone-Jovicich, S., \& Schmink, M. (2008). Environmental governance and the emergence of forest-based social movements (pp. 36p.). Bogor, Indonesia: CIFOR.

Drazkiewicz, A., Challies, E., \& Newig, J. (2015). Public participation and local environmental planning: Testing factors influencing decision quality and implementation in four case studies from Germany. Land Use Policy, 46, 211-222. doi: 10.1016/j.landusepol.2015.02.010.

Ekayani, M., Nuva, Yasmin, R.K., Shaffitri, L.R., Tampubolon, B.I. (2014). Taman Nasional untuk siapa? Tantangan membangun wisata alam berbasis masyarakat di Taman Nasional Gunung Halimun Salak. Risalah Kebijakan Pertanian dan Lingkungan, 1 (1)

Ekayani, M., Nurrochmat, D.R., Darusman, D., (2016). The role of scientists in forest fire media discourse and its potential influence for policyagenda setting in Indonesia. Journal of Forest Policy and Economics, 68 (2016), 22-29.

Eksva"rd, K., \& Rydberg, T. r. (2010). Integrating participatory learning and action research and systems ecology: A Potential for sustainable agriculture transitions. Systemic Practice Action Research, 23, 467-486. doi: $10.1007 / \mathrm{s} 11213-010-9172-6$ 
Fabinyi, M., Evans, L., \& Foale, S. J. (2014). Socialecological systems, social diversity, and power: insights from anthropology and political ecology. Ecology and Society, 19(4). doi: 10.5751/ES-07029-190428.

Fadli, F. (2014). Analysis of direct and indirect effect of fiscal decentralization and regional disparity (Case study provinces in East and West Indonesia Year 2006-2012). Journal of Economics and Sustainable Development, 5(18).

Faguet, J.-P. (2014). Decentralization and governance. World Development, 53, 2-13. doi:10.1016/j.worlddev.2013.01.002

Faludi, A. (2009). A turning point in the development of European spatial planning? The 'territorial agenda of the European Union' and the 'First Action Programme'. Progress in Planning, 71(1),1-42. doi: 10.1016/j.progress.2008.09.001

Florini, A. M. (1999). Does the invisible hand need a transparent glove? the politics of transparency. Paper presented at the The Annual World Bank Conference on Development Economics, Washington, D.C.

FPP, Pusaka, \& SHK, P. (2014). Securing forests securing rights. Report of the International Workshop on Deforestation and the Rights of Forest Peoples. Palangkaraya: Forest People Programme, Pusaka, and Kelompok Kerja Sistem Hutan Kerakyatan.

Frost, P., Campbell, B., Medina, G., \& Usongo, L. (2006). Landscape-scale approaches for integrated natural resource management in tropical forest landscapes. Ecology and Society,11(2): 30, 1-14.

Fung, B. (2014). The demand and need for transparency and disclosure in corporate governance. Universal Journal of Management,2(2), 72-80.

Garmestani, A. S., Allen, C. R., \& Cabezas, H. (2008). Panarchy, adaptive management and governance : policy options for building resilience. Nebraska Law Review, 87 (4)(5), 1-20.

Grimmelikhuijsen, S. (2012). Linking transparency,knowledge and citizen trust in government: an experiment. International Review of Administrative Sciences, 78(1), 50-73. doi: $10.1177 / 0020852311429667$

Hadiz, V. R. (2004). Decentralization and democracy in Indonesia: A critique of neo-institutionalist perspectives. Development and Change, 35(4),97-718.

Hartanto, H., Rangan, H., Thorburn, C., \& Kull, C. (2008). Strategic engagement and dynamic adaptation : customary forest management in Kerinci, Central Sumatra, Indonesia. Paper presented at the The 12th Biennial Conference of the International Association for the Study of Commons, England.

Hasan, H. A. (2013). Transparency, trust and vonfidence in the public sector. British Journal of Arts and Social Sciences, Vol.13 No.I. 
Heuer, M. (2011). Ecosystem cross-sector collaboration: conceptualizing an adaptive approach to sustainability governance. Business Strategy and the Environment, 20(4), 211-221.doi: 10.1002/bse.673

Huber, R., Briner, S., Peringer, A., Lauber, S., Seidl, R., Widmer, A., . . . Hirschi, C. (2013). Modeling social-ecological feedback effects in the implementation of payments for environmental services in pasturewoodlands. Ecology and Society, 18(2). doi: 10.5751/ES-05487180241

IWGIA. (2011). Update 2011 - Indonesia. The Indigenous World, Asia. Retrieved 13 May, 2013, from http://www.iwgia.org/regions/asia/indonesia/871-update-2011indonesia at 13 May 2013

IWGIA. (2016). The indigenous world 2016 (D. V.a. C. Mikkelsen Ed.). Copenhagen: The International Work Group for Indigenous Affairs.

Johnson, C. (2015). Indonesia: Declaration on Rights of Indigenous People to Forests. 29 April 2015. Retrieved from http://www.loc.gov/law/foreignnews/article/indonesiadeclaration-on-rights-of-indigenous-peopletoforests/ at 22 November 2016, 2016.

Jordan, A., Wurzel, R. K. W., \& Zito, A. (2005). The rise of 'new' policy instruments in comparative perspective: has governance eclipsed government? Political Studies, 53(3), 477-496.doi: 10.1111/j.14679248.2005.00540.x

Kawharu, M. (2011). Forestry and indigenous issues: New Zealand and the Pacific. Paper presented at the International Expert Group Meeting Indigenous Peoples and Forests, New York.

Kolb, D. A. (1984). The process of experiential learning: experience as the source of learning and development. Englewood Cliffs, New Jersey Prentice Hall.

Komisi Pemberantasan Korupsi (2010). Paparan hasil KPK tentang kehutanan. Siaran Pers. Retrieved 1 April 2012, 2012, from ttp://www.kpk.go.id/modules/news/article.php?storyid $=1726$

Kusumanto, T. (2007). Shaping opportunities for improving forest quality and community livelihoods in Central Sumatra and East Kalimantan, Indonesia. In R. Fisher, R. Prabhu \& C. McDougall (Eds.), Adaptive collaborative management of community forests in Asia experiences from Nepal, Indonesia and the Philippines (pp. 93-133). Bogor, Indonesia: Center for International Forestry Research.

Lesliea, H. M., Basurto, X., Nenadovic, M., Sievanena, L., Kyle C. Cavanaugh, Cota-Nieto, J. J., . . . Aburto-Oropezag, O. (2015). Operationalizing the social-ecological systems framework to assess sustainability. PNAS, 112/19, 5979-5984.

Lindstedt, C., \& Naurin, D. (2010). Transparency is not enough: making transparency effective in reducing corruption. International Political Science Review, 31(3), 301-322. doi: 10.1177/0192512110377602 
Loorbach, D. (2007). Transition management : New mode of governance for sustainable development. (Doctoral Thesis), Erasmus Universiteit Rotterdam, Rotherdam.

Marwa, J., Purnomo, H., Nurrochmat, D.R. (2010). Managing the last frontier of Indonesian forest in Papua. Fakultas Kehutanan IPB,Bogor.

McGinnis, M. D., \& Ostrom, E. (2014). Socialecological system framework: initial changes and continuing challenges. Ecology and Society, 19(2). doi: $10.5751 /$ ES-06387-190230

Moeliono, M., \& Dermawan, A. (2006). The impacts of decentralization on tenure and livelihoods. In C. Barr, I. A. P. Resosudarmo, A. Dermawan, J. McCarthy, M. Moeliono \& B. Setiono (Eds.), Decentralization of forest administration in Indonesia, implications for forest sustainability, economic development and community livelihoods (pp. 108-120). Bogor: Center for International Forestry Research.

Moniaga, S. (2009). Fighting over the land and forest. Retrieved from http://www.insideindonesia.org/fighting-over-the-land-and-forest at 22 November 2016.

Nizar, M. (2010). RTRW Aceh harus jamin hak masyarakat. Lingkungan Hidup. 15 August $2010 . \quad$ Retrieved from http://www.kabarindonesia.com/berita. p? pil=4\&jd=RTRW+Aceh+Harus +Jamin+Hak+Masyarakat\&dn=20100814121205 at 26 August 2010

Nurrochmat, D.R., 2005. The Impacts of regional autonomy on political dynamics, socioeconomics and forest degradation. Case of JambiIndonesia. Cuvillier Verlag: Goettingen.

Nurrochmat, D.R., Darusman, D.R., Ekayani, M.,(2016). Kebijakan pembangunan kehutanan dan lingkungan: teori dan implementasi. IPB Press, Bogor.

Osakede, K. O., \& Ijimakinwa, S. O. (2015). Traditional institution and the modern dayadministration of nigeria: Issues and prospects. Journal of Research and Development (RnD), 2(9).

Peisakhin, L. (2012). Transparency and corruption: evidence from India. The Journal of Law \& Economics, 55(1), 129-149. doi: 10.1086/663727

Prasad, K., Strzepek, K., \& Kopen, B. v. (2004). Addressing socioeconomic objectives through enhanced decision support systems for water resources management: Vision, aps, and challenges in South Africa. Systemic, Cybernetics and Informatics, 3 (6), 1-6.

Raharjo, O. P. (2014). Evaluating the role of ADAT community in spatial planning in Paser, East Kalimantan. (Master of Science Theses), University of Twente, The Netherlands.

Kehutanan, UU 41 Tahun 1999 C.F.R. (1999). Perlindungan dan Pengelolaan Lingkungan Hidup, Lembaran Negara Republik Indonesia Tahun 2009 Nomor 140 C.F.R. (2009a). Perlindungan dan Pengelolaan Lingkungan Hidup, UU 32 tahun 2009 C.F.R. (2009b). 
Rhodes, R. A. W. (1996). The new governance: Governing without government. Political Studies, 44(4), 652-667. doi: 10.1111/j.14679248.1996.tb01747.x

Rodríguez Bolívar, M. P., Navarro Galera, A., \& Alcaide Muñoz, L. (2015). Governance, transparency and accountability: An international comparison. Journal of Policy Modeling, 37(1), 136-174. doi: http://dx.doi.org/10.1016/j.jpolmod.2015.01.010

Roslinda, E., Darusman, D., Suharjito, D., Nurrochmat, D.R. (2012). Stakeholders analysis on the management of Danau Sentarum National Park Kapuas Hulu Regency, West Kalimantan. Jurnal Manajemen Hutan Tropika, 18 (2) 78-85.

Royer, S. D., Visser, L. E., Galudra, G., Pradhan, U.,\& Noordwijk, M. V. (2015). Self-identification of indigenous people in postindependence Indonesia: a historical analysis in the context of REDD+. International Forestry Review, 17(3).

Ryan, R. L. (2011). The social landscape of planning: Integrating social and perceptual research with spatial planning information. Landscape and Urban Planning, 100(4), 361-363. doi: 10.1016/j.landurbplan.2011.01.015

Schmeer, K. (1999). Guidlines for conducting a stakeholder analysis. Bethesda, MD: Abt Associates Inc.

Suwarno, A., Hein, L., \& Sumarga, E. (2015). Governance, decentralisation and deforestation: The case of Central Kalimantan Province, Indonesia. Quarterly Journal of International Agriculture, 54, No. 1, 77-100.

Takim, R., Shaari, S. M., \& Nordin, R. M. (2013). Transparency initiative (TI) for enhancing quality of life: behavioural components that lead to corruption in construction.Procedia - Social and Behavioral Sciences, 101, 110-119. doi: http://dx.doi.org/10.1016/j.sbspro.2013.07.184

Tambunan, I. (2012). 33.000 konflik perlu kepastian hukum. Konflik Lahan. 6 Mei 2012. Retrieved from http://regional.kompas.com/read/2012/05/06/12084186/.33.000.Konfl ik.Perlu.Kepastian. Hukum At 2 Agustus 2012.

The Union for Ethical BioTrade (2013). Fair and equitable benefit sharing, Manual for the assessment of policies and practices along natural ingredient supply chains: The Union for Ethical Bio Trade

UNEP. (2011). Emerging Perspectives on Forest Biodiversity. UNEP Year Book 2011. United Nations Environment Programme

UNEP. (2012). Deforestation Costing Kenyan economy millions of dollars each year and increasing water shortage risk. Retrieved from http://www.unep.org/Documents. Multilingual/Default.DocumentID $=269$ $\underline{8 \& \text { ArticleID }=9316 \& \mathrm{l}=\text { en }}$ at 5 November 2012

UNEP. (2013). Governance for Peace over natural Resources A review of transitions in environmental governance across Africa as a resource for 
peacebuilding and environmental management in Sudan. Kenya: United Nations Environment Programme.

Wijaya, T. (2014). Tokoh ADAT disidangkan, NGO akan gugat perusahaan perambah SM Dangku. Retrieved from http://www.mongabay.co.id/2014/09/24/tokoh-ADAT-disidangkanngoakan-gugat-perusahaan-perambah-smdangku/at 24 September 2014.

Wulan, Y. C., Yasmi, Y., Purba, C., \& Wollenberg, E. (2004). Analisa konflik sektor kehutanan di Indonesia 1997-2003. Bogor: CIFOR.

Yazdi, S. V. (2013). Review of Centralization and decentralization approaches to curriculum development in Iran. International Journal of Academic Research in Business and Social Sciences, 3,(4) 97-115.

Zakaria, Y. (2017, 10 February 2017). After the customary forest recognition.26 January 2017. Retrieved from http://www.thejakartapost.com/academia/2017/01/26/after-thecustomary-forest-recognition.html. at 10 February 2017. 


\title{
CHAPTER 3
}

\author{
EXPANSION OF TRADITIONAL LAND-USE AND \\ DEFORESTATION: A CASE STUDY OF AN ADAT FOREST \\ IN THE KANDILO SUBWATERSHED, EAST KALIMANTAN, \\ INDONESIA ${ }^{2}$
}

2 This Chapter is based on :

Nugroho, H. Y. S. H., van der Veen, A., Skidmore, A. K., \& Hussin, Y. A. (2017).

Expansion of traditional land-use and deforestation: a case study of an ADAT forest in the Kandilo Subwatershed, East Kalimantan, Indonesia. Journal of Forestry Research (2018) 29(2):495-513 https://doi.org/10.1007/s11676-017-0449-9 


\begin{abstract}
Deforestation issues are more problematic when indigenous (ADAT) communities, living within a forest, have lived there for many generations. These ADAT communities, who employ traditional land-use, are frequently accused of encroaching on the forest. To understand existing and future trends in the spatial patterns of the expansion of traditional land-use and deforestation, we conducted a case study in the Kandilo Subwatershed using mixed methods with image interpretation, spatial modelling and sociocultural surveys to examine the interrelationships between physical conditions, community characteristics and traditional land-use expansion. We investigated community characteristics through household interviews, communication with key informants, and discussions with focus groups. By using an area production model, we were able to analyze the effect of improved farming systems, policy intervention and law enforcement on traditional land-use expansion and deforestation. Based on our examination of a 20-year period of traditional land-use activities in ADAT forests, the evidence indicated that the steeper the slope of the land and the farther the distance from the village, the lower the rate of deforestation. Our study found that customary law, regulating traditional land-use, played an important role in controlling deforestation and land degradation. We conclude that the integration of land allocation, improved farming practices and enforcement of customary law are effective measures to improve traditional land productivity while avoiding deforestation and land degradation.
\end{abstract}

Keywords: ADAT people, Agriculture expansion, Area production model (APM), Customary law, Deforestation, Traditional land-use

\title{
3.1 Introduction
}

Deforestation is defined as the conversion process of forested land to nonforested land (Blaser 2010; Boucher et al. 2011; Kementerian Kehutanan 2011). The most common causes of deforestation include resource privatization, fiscal incentives for land conversion, tenure policies, urbanization, resettlement development, and in tropical areas, the demand for agricultural land is the main driver (Adams et al. 2013; Akinyemi 2013; Barbier 2004; Boafo 2013; Chi et al. 2013; Foley et al. 2005; Palm et al. 2010; Shearman et al. 2009). According to the FAO (2011), during the period 2000-2010, the annual world rate of forest conversion to agricultural land was approximately 13 million hectares. For the period 1990-2005, Indonesia was responsible for approximately $23 \%$ (1.9 million ha/year) of deforestation worldwide (the highest deforestation rate in the world), and slowed to 0.68 million ha/year between 2005 and 2010 (FAO 2011). 
Recent evidence shows that in areas with a high rate of deforestation, commercial farmers are the main agents of deforestation (Adams et al. 2013; Lininger 2011; Mertz 2009; Rudel et al. 2009; Seidenberg et al. 2003). In areas with low deforestation rates, however, small farmers and subsistence shifting cultivation are seen as the major contributors (Damnyag et al. 2013; Geist and Lambin 2002; Lininger 2011; Rudel et al. 2010; Shearman et al. 2009). The potential pressure of small farms on forests is high due to the millions of people who rely on agriculture for their livelihoods, dwelling in or near forest areas. In Indonesia, approximately 25,800 villages (36.7\% of all villages in Indonesia) are inside or adjacent to forest areas. Of these, $98 \%$ rely on agriculture for their livelihoods (Badan Planologi Kehutanan 2007; Direktorat Jenderal Planologi Kehutanan 2009).

These issues are more problematic when indigenous people have lived inside the forest for many generations. In Indonesia, ADAT or customary land rights and customary systems of tenure have become a critical element of contention (Heryani and Grant 2004; Yasmi et al. 2010). Following the introduction of Forestry Law No. 41/1999, concerning the change in status from ADAT forest to state forest, ADAT communities living in these forests, who have done so for generations, have been accused of encroaching (Hartanto et al. 2008). In many parts of Indonesia, ADAT communities have been blamed for deforestation and forest destruction (Cahyadi 2014; IWGIA 2011; Wijaya 2014).

Traditionally, ADAT land-use is a system of shifting cultivation that incorporates long fallow periods based on indigenous knowledge and bound by customary laws. Based on their research, scientists believe that indigenous knowledge is a valuable source for maintaining a balance between natural resource conservation and farming activities (Chun 2014; Mulyoutami et al. 2009; Wangpakapattanawong et al. 2010). In this paper, we will test the hypothesis that managed forest based on customary law and indigenous wisdom will report lower rate of deforestation.

Previous studies from many countries show how improved productivity and policy interventions concerning land rights security have positive impacts on food security and deterring deforestation (Angelsen and Kaimowitz, 2001; Araujo et al. 2010; Branca et al. 2011; Chi et al. 2013; Epule et al. 2014; Fearnside 2001; Tachibana et al. 2001; Tomich et al. 2001). However, there are still knowledge gaps, especially in the relationships between and among the biophysical, economic development, sociocultural aspects, and effective policy responses (Carr 2008; Chomitz et al. 2007; Damnyag et al. 2013; Mattsson et al. 2012; Pasgaard 2013; Pouliot et al. 2012). Moreover, most studies of deforestation drivers have been based on macrolevel regional or 
national data, thus presenting difficulties in addressing the complexity of local situations (Bottazzi and Dao 2013).

The aim of this study was to generate an understanding of spatial patterns of existing and future trends in traditional land-use expansion and deforestation. We used image interpretation, spatial modelling and sociocultural surveys to examine interrelationships between and among the physical conditions, community characteristics and traditional land-use expansion. In this paper, traditional land-use refers to shifting agricultural systems with very low or no external inputs and low outputs (Gonzales Bernaldez 1991; Ochoa-Gaona 2001; Plieninger et al. 2006; Susana and Ochoa-Gaona 2011). Using an area production model (APM), we simulated the effect of improved traditional farming systems, policy intervention and law enforcement on traditional landuse expansion and deforestation.

\subsection{Material and Methods}

\subsubsection{Research area}

Kandilo Subwatershed (Figure 3.1) is located in the Paser District in southeastern East Kalimantan Province, Indonesia, on the island of Borneo. The area covers 206,460 ha distributed over 17 villages of two subdistricts (Muara Komam and Batu Sopang). Its main river, the Kandilo (181 km), flows from the Mount Lumut Protection Forest $(1210 \mathrm{~m}$ a.s.l.) to the downstream flood plain in Tanah Grogot, the capital city of Paser District. The Kandilo River is the main water source for the lowland areas of Paser District. Approximately 96 million $\mathrm{m} 3$ /year of irrigation and domestic water, valued at US $\$ 7.8$ million per year, is provided by Mount Lumut Protection Forest (Tropenbos International Indonesia 2006). 


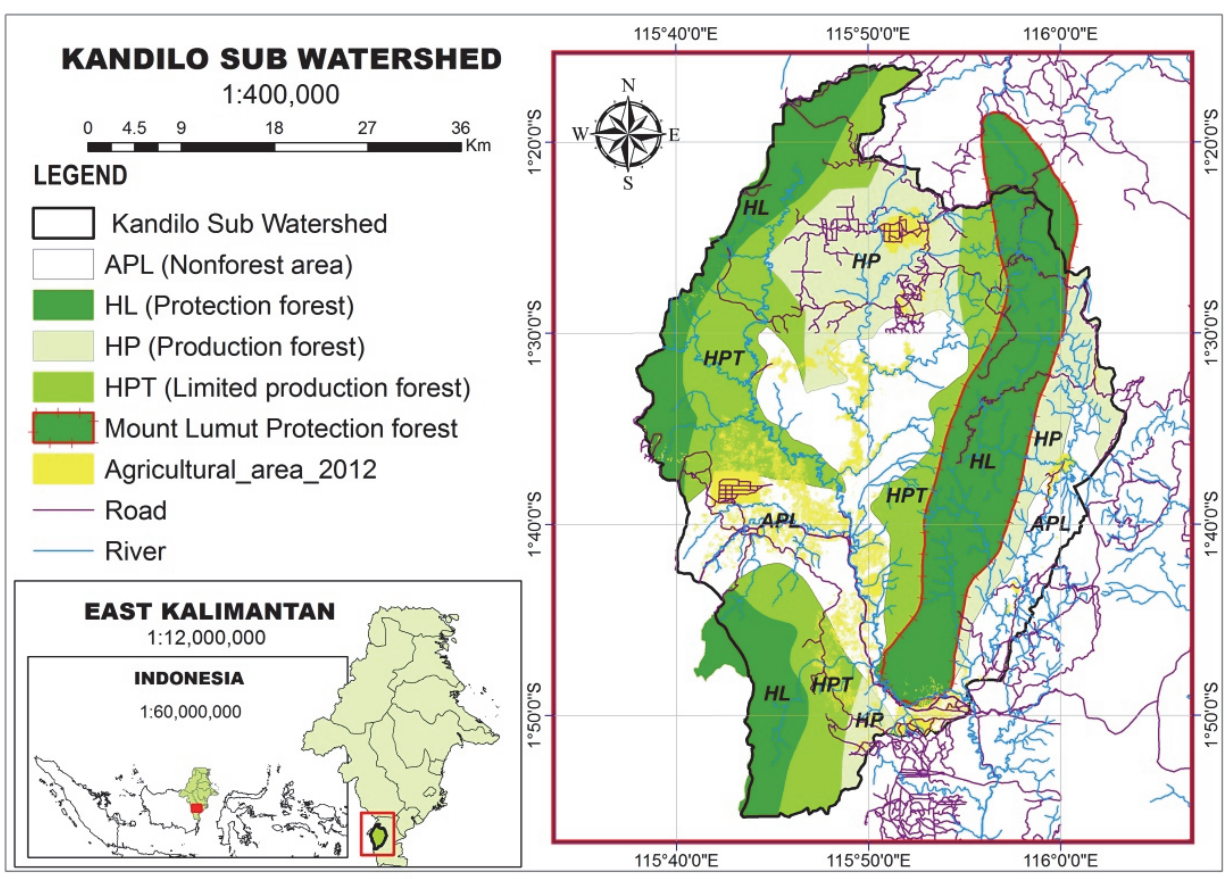

Figure 3. 1. Map of Kandilo Subwatershed

Based on the analysis of the Designation of Provincial Forest Area and Inland Water, Coastal and Marine Ecosystems Map (Ministry of Forestry Decree No. $79 / \mathrm{Kpts}-\mathrm{II} / 2001), 22 \%$ of the Kandilo Subwatershed $(46,250 \mathrm{ha})$ is a nonforest area (Area Penggunaan Lain-APL) and 78\% (160,210 ha) is forest zone: protection forest (Hutan Lindung-HL), production forest (Hutan Produksi-HP) and limited production forest (Hutan Produksi terbatas-HPT). Based on our analysis of land cover for 2012, forested land covered 160,914 ha. Agricultural land covered 30,090 ha, consisting of subsistence food crops $(27,147 \mathrm{ha})$, oil palm (1444 ha), and rubber plantations (1449 ha); $34 \%$ of the subsistence food crops, $17 \%$ of the oil palm, and $10 \%$ of the rubber plantation areas were situated in forest zones.

The people in the Kandilo Subwatershed represent three sociocultural backgrounds: (1) Paser indigenous people (Dayak Paser), (2) Banjar people, immigrants from South Kalimantan, and (3) migrants from outside Kalimantan, primarily from Java and Sulawesi through the central government Transmigration Program. Subsistence farming with minimum inputs and outputs is the most common agricultural system in the study area. The immigrants originally practiced permanent farming systems of planting food crops (e.g., upland rice, soybeans, maize) and rubber. The ADAT communities cultivated primarily upland rice in shifting cultivation systems 
applying very low amounts of fertilizer, herbicides and other agrochemical inputs.

Traditionally, land parcels were 1-3 ha per parcel, constant from year to year. Upland rice was planted for two to three seasons (2-3 years) followed by an average of 10 years fallow. After 3 years, when soil fertility diminished, farmers moved to regenerated secondary forest, their previous fallowed sites, and cleared them using slash and burn methods.

The upland rice, oil palm, and rubber ADAT communities planted an annual average production of $0.6,3.6$ and 0.48 tons/ha respectively. This is low when compared to the annual district productivity levels of 2.9, 14, and 1.4 tons/ha in the same period (2010-2011) (BPS Kabupaten Pasir 2011). Based on a standard conversion from unhusked rice to husked rice (milling yield) in Indonesia, which is $62.7 \%$ (Suhari 2015), an average number of household members of five people and an average extent of cultivated land about 1 ha per household, rice production in the study area was estimated equal to 107 $\mathrm{kg}$ per capita per year. Minimum standard of living for rural people in Indonesia is equivalent to $132 \mathrm{~kg}$ of rice per capita per year (Ratnasari 2013), and the optimum standard of living (including sugar, fish, meat, clothes, housing, education) is equivalent to 1 ton of rice per capita per year (KLH 2009).

However, in the last decade, villagers in general in many parts of the world have started to change their farming methods from shifting to permanent cultivation (Hariyadi and Ticktin 2012; Heinimann et al. 2013; Mertz 2009). In response to better access to urban areas and changing prices, many farmers have started to cultivate permanent rubber or oil palm crops mixed with upland rice. After 3 years, when the rubber/oil palm canopies block the sun and upland rice cannot grow, they start to clear new land for another plantation of mixed crops. However, due to the presence of the rubber and oil palm, the farmers no longer return to a parcel of land after 15 years. After 3 years, they look for new land to cultivate. Without appropriate measures from both external and/or internal institutions, this uncontrolled system will lead to excessive deforestation.

\subsubsection{Data preparation}

We collected both spatial and nonspatial data. Our spatial data consisted of maps of land-use, designated forest, slope, rivers, roads, settlements, and ADAT forest. Satellite images with less than $10 \%$ cloud cover from 6 years (1992, 1996, 2000, 2006, 2009 and 2012) were analyzed using image processing software Ermapper 7.1 (Earth Resource Mapping, USA) and 
ArcGIS 10.1 (Esri, Redlands, CA, USA) to produce land-use and land cover maps based on the APM land-use classification.

Spatial APM differentiates land-use into three land categories: agricultural, forest, and other (Forest Science Division 2001). Each category is then divided into subcategories (agricultural land: subsistence food, local market and industrial crops; forest land: farm, industrial and environmental forests; other land: potential agricultural, potential forest and unproductive land). For an accurate classification, several ground checks were conducted from 2009 to 2013. In this study, shifting agricultural systems with very low or no inputs were categorized as subsistence crops. Oil palm and rubber plantations were classified as market crops. Settlements, rivers, and lakes were classified as unproductive land.

Nonspatial data consisted of district and village level data. District level data covered population growth, gross domestic product/capita, agricultural and commodity productivity derived from a series of statistical data of Paser Regency from 2000 to 2012. Data at the village level was collected using surveys through informal dialogues with individuals, household interviews using questionnaires, interviews with key informants, focus group discussions, farmland/field visits and analysis of secondary data from annual unpublished village reports that provide basic data and information on the village from 2000 to 2012. For a better understanding of how sociocultural variables influence land-use change and deforestation, we observed three communities living in forest areas representing different cultures: (1) Muluy (ADAT community), (2) Rantau Layung and Rantau Buta (mixed ADAT and migrant community), and (3) Swan Slutung (migrant community). The three communities were visited periodically from 2009 to 2013 to observing daily activities, norms and beliefs through deep interviews, focus group discussions (FGDs) and informal meetings. Our hypothesis was that different cultures will have different opinions and preferences and will behave differently, which will affect deforestation differently.

To acquire more detailed information on specific issues, we conducted personal interviews with key respondents such as ADAT heads and elders.

Achieving accurate sociocultural data based on direct interviews was challenging since some respondents refrained from openly discussing their "considered-illegal" forest-based activities. To minimize misinformation and to anticipate some inconsistent responses, especially with regard to farming systems, forest-based income generation, implementation of customary law, and the extent and location of traditional land-use, we conducted a series of periodic field visits from 2009 to 2013. 


\subsubsection{Analysis of Existing traditional land-use expansion}

By overlaying a series of land-use and land cover maps, we were able to calculate and locate traditional land-use expansion and forest conversion. In this study, upland rice, rubber and oil palm plantations cultivated by ADAT communities were classified as traditional land-use. The main output of this analysis process was a map of existing (observed) traditional land-use expansion from 1992 to 2012 .

By overlaying this map with maps of slope class, roads, rivers and villages, we were able to calculate the extent and density of traditional land-use expansion based on slope class, and distance from road, river and/or village. Further, the observed land-use change was used to validate the APM by comparing the observed to the predicted expansion (APM output) in the same period pixel by pixel.

\subsubsection{Modelling traditional land-use expansion and forets conversion}

Modelling is a simplification of reality to enhance understanding of the systems scientifically and to project future outcomes (Jakeman et al. 2009; Wa"tzold et al. 2006). In this study, we used APM, a simulation model of land-use changes (Hussin et al. 1995; Sandewall and Nilsson 2001; Xiao et al. 2001), to project traditional land-use expansion in the future as a response to exogenous variable changes: human population pressure, economic development, improved agricultural productivity and policy intervention. The APM was developed in 1982 by the FAO to numerically simulate land-use changes. In 1991, APM was connected to the Integrated Land and Water Information System (ILWIS), a raster-based geographic information system (GIS) by de Gier and Hussin to improve the spatial capacity of the model in predicting which areas would be the new land-use (Forest Science Division 2001; Hussin et al. 1995). On the basis of several uses at different sites, APM is considered an appropriate tool to model deforestation and forest degradation (Ato 1996; Hamzah 2012; Hussin et al. 1995; Sandewall and Nilsson 2001; Sawathvong 2004; Yanuariadi 1999).

The area production model runs on three assumptions: (1) the demand for subsistence crops depends only on population growth, (2) the demand for market crops and industrial/export crops is influenced by economic factors (GDP), and (3) production depends on productivity and the extent of the cultivated area (Forest Science Division 2001). These assumptions are in line with findings mentioned by several scholars. The correlation between agricultural land demand and deforestation is significantly affected by population pressure (Akinyemi 2013; Chi et al. 2013; Entwisle et al. 2008; 
Mertens et al. 2000; Pfeffer et al. 2005), accessibility (Entwisle et al. 2008; Lininger 2011; May-Tobin 2011; Purnamasari 2010), growth of income per capita, rising costs, price of agricultural products, and other macroeconomic factors (Barbier, 2004; Gaveau et al. 2009; Mertens et al. 2000).

There are two steps to predict future deforestation. The first step is to calculate agricultural demand using numerical APM, and the second step is to predict spatial deforestation using spatial APM.

The demand for new land for agriculture was calculated using the following formula (Forest Science Division 2001):

$N_{\mathbf{A g}}=\left[C_{\mathbf{S}}(\mathrm{iPop} / \mathrm{iAgs})^{n}\right]+\left[\mathrm{C}_{\mathbf{M}}\left(\mathrm{i} G D P / \mathrm{iAg}_{\mathbf{M}}\right)^{n}\right]+\left[C_{\mathbf{I}}\left(\mathrm{i} G D P / \mathrm{iAg}_{\mathbf{I n}}\right)^{n}\right]$,

where $\mathrm{NAg}$ is the projected area of agricultural land, $\mathrm{n}$ is the number of simulation years, $\mathrm{N}$ is the new area needed, $\mathrm{C}$ is the current area, iPop is the growth factor of population, Pop is the population, iAgs is the growth factor of subsistence crop productivity, iAgM is the growth factor of market crop productivity, iAgIn is the growth factor of industrial crop productivity, iGDP is the growth factor of gross domestic product.

The total demand for agricultural lands resulting from the numerical APM will be written in the ILWIS script as an input for a spatial APM to predict spatial/locational distribution of new agricultural land. When demand is positive, there will be land-use conversion from nonagricultural land (forest and shrub). Spatial APM assumes that land-use conversion starts from the periphery of existing agricultural land and converted to forestland or other land according to a friction value and the distance to an agricultural area. In general, when demand for agricultural land increases, land transfer from another class is generated in a certain priority order (Hussin et al. 1995; Sawathvong 2004; Yanuariadi 1999). The general framework of the spatial APM is presented in Figure 3.2. 


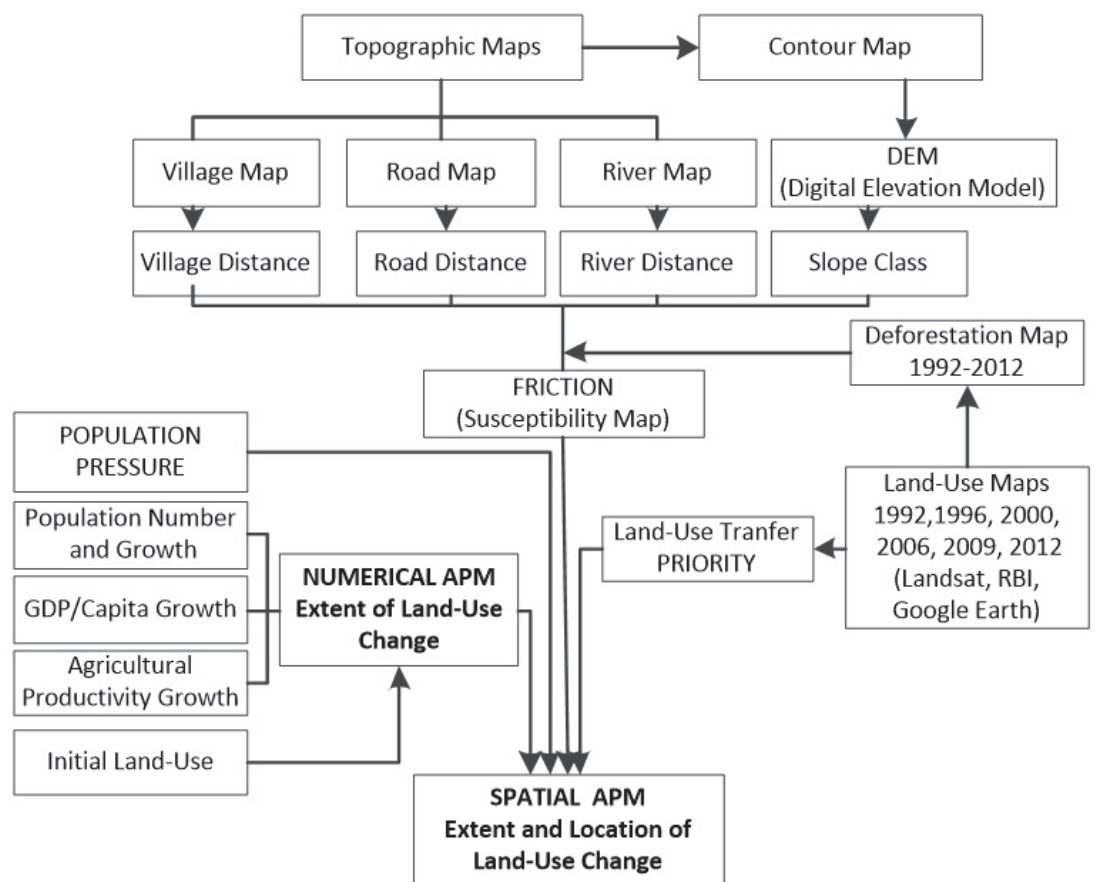

Figure 3. 2. Framework of spatial APM

The growth factors for this simulation are presented in Table 3.1. Growth of population, GDP and agricultural productivity in the Paser District were analyzed from statistical data for the Paser District. Productivity growth at the village level was derived from our village surveys.

Tabel 3. 1. Growth factors for the period 2000 to 2012

\begin{tabular}{|c|c|c|c|c|c|c|c|c|c|}
\hline \multirow{3}{*}{ Year } & \multirow{2}{*}{\multicolumn{2}{|c|}{ Population Growth }} & \multirow{3}{*}{$\begin{array}{l}\text { GDP Growth } \\
\text { District }\end{array}$} & \multicolumn{6}{|c|}{ Growth of Crop Productivity/Increase in Crop Productivity } \\
\hline & & & & \multicolumn{2}{|c|}{$\begin{array}{l}\text { Subsistence Crops } \\
\text { (Upland rice) }\end{array}$} & \multicolumn{2}{|c|}{$\begin{array}{l}\text { Market Crops } \\
\text { (Oil Palm) }\end{array}$} & \multicolumn{2}{|c|}{$\begin{array}{l}\text { Market Crops } \\
\text { (Rubber) }\end{array}$} \\
\hline & District & Villages & & District & Villages & District & Villages & District & Villages \\
\hline $2000-2006$ & $1.027^{*}$ & 1.020 & 1.079 & 1.039 & $0.78 * *$ & 1.072 & 1.001 & 1.003 & 0.985 \\
\hline $2006-2012$ & 1.053 & 1.029 & 1.092 & 1.014 & 0.76 & 1.024 & 1.018 & 1.001 & 0.985 \\
\hline
\end{tabular}

Note: $* 1.027$ means $2.7 \%$ growth; $* * 0.78$ means $22 \%$ decline

\subsubsection{Analysis of the factor map}

We found four factors that influenced deforestation susceptibility: distance to village, distance to roads, distance to rivers, and slope. The APM assumes a positive relationship between the distance from villages to forests and land conversion; moreover, the steeper the slope, the slower the land conversion. Each factor was analyzed separately to identify its significance in affecting land-use conversion. Then each factor was crossed with the observed landuse conversion in order to calculate the density value for each factor. Density values were calculated as a percentage of the converted area for each factor. 


\subsubsection{Model validation}

Validation was conducted by overlaying predicted land-use conversion maps with observed land-use conversion maps for the same periods. Due to data availability (population, GDP, and agriculture production), the APM validation was run for the period 2000-2012. For spatial validation, we compared the predicted and observed maps pixel by pixel. The number of overlapping pixels of the twomaps represents the accuracy of APM in projecting locations of land-use conversion.

\subsubsection{Scenario development and model simulation}

Scenario development refers to the creative process to define the pathways of exogenous variables for particular systems to deal with future complexities and uncertainties (Verburg et al. 2006; Wollenberg et al. 2000).

We conducted model simulations to project the impacts of exogenous variables (population pressure, economic development, improved farming practices and policy intervention) on the future state of traditional land use and deforestation.

The simulation period was 25 years (2012-2037) applying the following sets of assumptions: (1) Population growth was projected to simulate population pressure. (2) GDP growth was projected to simulate economic development.

(3) Increased agriculture productivity was projected to simulate improved farming practices. (4) The order of priority of land-use transfer was changed to simulate policy interventions and law enforcement.

The challenge in developing scenarios, however, was to produce realistic values for input variables. In this study, input variables at the village level were projected based on our survey findings. Concurrently, regional level variables (population and GDP growth) were synchronized with projections by the National and Regional Planning Agency (BAPPEDA Kalimantan Timur 2008; BAPPENAS 2005).

Based on actual data and information generated from our village surveys, we developed three scenarios: an unexpected, an expected, and a visionary outcome. The first considers unexpected situations to reflect the negative that the existing situation could deteriorate. The second scenario estimates the most likely outcomes driven by existing trends of exogenous factors, a business-as-usual scenario. The third scenario reflects our vision about future livelihood security, land tenure certainty, and synergizing ADAT law (hukum ADAT) and formal law. 


\section{Scenario 1: unexpected outcomes}

Under the unexpected outcome scenario, the population will increase constantly at the previous growth rate until the second period and then ascend. In the existing situation, there is illegal immigration of people looking for land as a result of new road developments passing through the forest area. Conversely, the young people from forest villages move to peri-urban and urban areas in search of off-farm employment and will leave their land unmanaged. We assume that this phenomenon will persist until the second period. In this scenario, productivity of food crops is constant as a result of limited labor, good quality seed and fertilizer. Meanwhile, industrial crop productivity (oil palm and rubber plantations) will start to increase slowly in the fourth period. In terms of economic development, the GDP per capita will increase following the trend in agricultural sectors at the provincial level, but will slow down in the third period. We assume that there is no significant new policy concerning forest management throughout the duration of the scenarios. In the existing situation, the regional forestry office conducts insufficient forest monitoring and law enforcement due to limited authority and budget. Local institutions, wisdom, norms and values of the ADAT communities are slowly being eroded by consumerism and short-term economic considerations. For the APM in this situation, we have given the same priority to all landuse types in terms of land-use conversion. At the same time, agricultural land will expand taking over all other types of land. Slope and accessibility are the only factors determining which area will be converted first. The growth factors for Scenario 1 are presented in Table 3.2.

Tabel 3. 2. Growth factors in Scenario 1

\begin{tabular}{lcccccc}
\hline \multirow{2}{*}{ Period } & \multirow{2}{*}{ Year } & \multirow{2}{*}{$\begin{array}{c}\text { Population } \\
\text { Growth }\end{array}$} & \multirow{2}{*}{ GDP } & \multicolumn{3}{c}{ Grops Productivity Growth } \\
\cline { 5 - 7 } & & & & $\begin{array}{c}\text { Upland } \\
\text { Rice }\end{array}$ & Oil Palm & Rubber \\
\hline 1 & $2012-2017$ & 1.0300 & 1.092 & 1.0000 & 1.0010 & 1.0010 \\
2 & $2018-2022$ & 1.0300 & 1.092 & 1.0000 & 1.0010 & 1.0010 \\
3 & $2023-2027$ & 1.0600 & 1.092 & 1.0000 & 1.0100 & 1.0100 \\
4 & $2028-2032$ & 1.0800 & 1.092 & 1.0000 & 1.0100 & 1.0100 \\
5 & $2033-2037$ & 1.0800 & 1.092 & 1.0000 & 1.0160 & 1.0160 \\
\hline
\end{tabular}

Scenario 2: expected outcomes, business as usual

Under the scenario of business as usual, the population growth is constant in forest villages and increase in villages outside forests after the second period following the growth trend at the provincial level (BAPPENAS 2005). Better prospects of on-farm income trigger people from other area to migrate into slightly sloped areas in the forest periphery.

Productivity of food and market crops in forest villages is constant until 2025 but will then increase. Meanwhile, in the villages outside forests, we assume 
that the Ministry of Agriculture Regional Office will introduce new technologies and deliver better production inputs to farmers. In terms of economic development, the GDP per capita will increase following the trend in agricultural sectors at the provincial level (BAPPEDA Kalimantan Timur 2008). In this scenario, we assume that the Ministry of Forestry Regional Offices will start to enforce the law. But due to limited authority and resources, these efforts will only focus on protection forests close to roads and villages. In our spatial APM, the scenario of such policy interventions will be executed by setting a certain priority order of landuse conversion. The conversion of protection forest will not start until all land in the higher priority classes has been converted. The growth factors for Scenario 2 are presented in Table 3.2.

Tabel 3. 3. Growth factors in Scenario 2

\begin{tabular}{lcccccc}
\hline \multirow{2}{*}{ Period } & \multirow{2}{*}{ Year } & Population & GDP & \multicolumn{3}{c}{ Crops Productivity Growth } \\
\cline { 5 - 7 } & & Growth & Growth & Upland rice & Oil palm & Rubber \\
\hline 1 & $2012-2017$ & 1.0200 & 1.0920 & 1.0000 & 1.0010 & 1.0010 \\
2 & $2018-2022$ & 1.0200 & 1.0920 & 1.0000 & 1.0100 & 1.0100 \\
3 & $2023-2027$ & 1.0500 & 1.0920 & 1.0000 & 1.0200 & 1.0200 \\
4 & $2028-2032$ & 1.0600 & 1.0920 & 1.0000 & 1.0400 & 1.0400 \\
5 & $2033-2037$ & 1.0600 & 1.0920 & 1.0000 & 1.0600 & 1.0400 \\
\hline
\end{tabular}

Scenario 3: visionary outcome

Under this scenario, population growth in all villages will increase after the second period following population growth rates at the district level. The GDP per capita will increase following the trend in the agricultural sector, especially for oil palm and rubber. We assume that the central government will enact new regulations concerning forest boundaries. Disturbed production forests in areas with slopes under $40 \%$ will be excluded from state forests and handed over to indigenous communities (Figure 3.3). In this policy scheme, ADAT communities will have legal tenure to manage their land. 


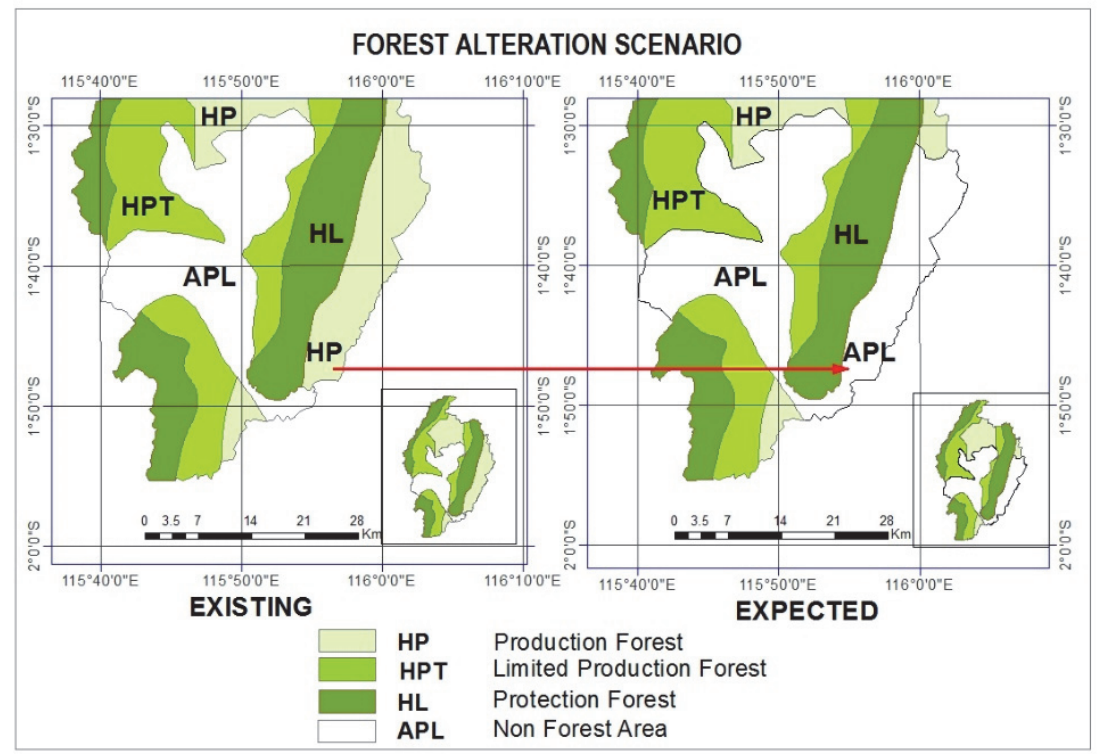

Figure 3. 3. Forest zone alteration in Scenario 3

Under Scenario 3, according to the proposed regulations, several villages will be situated in nonforest areas. As a result, villagers who formerly utilized forestland using subsistence farming methods, will improve their farming systems due to tenure security by applying better technology and production inputs to increase productivity. The regional offices (Ministry of Agriculture) will introduce better farming techniques and deliver better production inputs (fertilizer, seedlings) to farmers living outside forest areas.

Under Scenario 3, formal laws will be enforced consistently in line with ADAT law implementation. Protection forest will only be utilized by indigenous people in limited areas, under strict monitoring and with no disturbance to the environment. This includes restrictions on the use of the riparian buffer zone $100 \mathrm{~m}$ to the left and right of the riverbank and forestland with slopes above $40 \%$. In this scenario, we assume that customary rights and ADAT institutions will consistently regulate the daily activities of the ADAT people. In restricted areas, based on customary law, farming activities will not be allowed. In the APM, implementation of policy intervention and revitalization of ADAT rule are simulated by reclassifying land-use codes and resetting the order of priority from low to high: nonforest areas, production forest, limited production forest and protection forest. In this order, deforestation in protection forests will not start before production forests are deforested/converted to another use. The riparian buffer zone and sloping areas above $40 \%$ were classified as unproductive land and were given a value of 0 (zero) in the priority order. By having 0 value, the areas will not be 
converted to agriculture land. The growth factors for Scenario 3 are presented in Table 3.4.

Tabel 3. 4. Growth factors in Scenario 3

\begin{tabular}{lllllll}
\hline \multirow{2}{*}{ Period } & \multirow{2}{*}{ Year } & $\begin{array}{l}\text { Population } \\
\text { Growth }\end{array}$ & \multirow{2}{*}{ GDP Growth } & \multicolumn{3}{l}{ Crops Productivity Growth } \\
\cline { 6 - 8 } \cline { 5 - 7 } & & & Upland Rice & Oil Palm & Rubber \\
\hline 1 & $2012-2017$ & 1.030 & 1.100 & 1.020 & 1.020 & 1.000 \\
2 & $2018-2022$ & 1.025 & 1.110 & 1.020 & 1.040 & 1.040 \\
3 & $2023-2027$ & 1.020 & 1.130 & 1.050 & 1.040 & 1.040 \\
4 & $2028-2032$ & 1.060 & 1.140 & 1.050 & 1.060 & 1.080 \\
5 & $2033-2037$ & 1.060 & 1.150 & 1.050 & 1.060 & 1.080 \\
\hline
\end{tabular}

\subsection{Results}

\subsubsection{Traditional land-use expansion for the period 1992-2012}

The land-use and cover changes from 1992 to 2012 are illustrated in Figure 3.4 and 3.5. Figure 3.4 shows the spatial distribution of traditional land-use expansion, and Figure 3.5 shows trends in each land-use change. From 1992 to 2012 , forest cover decreased from 185,957 to 175,515 ha at a rate of $0.29 \%$ per year. Shrub increased from 12,605 to 14,664 ha at a rate of $0.74 \%$ per year and traditional farming increased from 6412 to 30,090 ha at a rate of $8.1 \%$ per year.

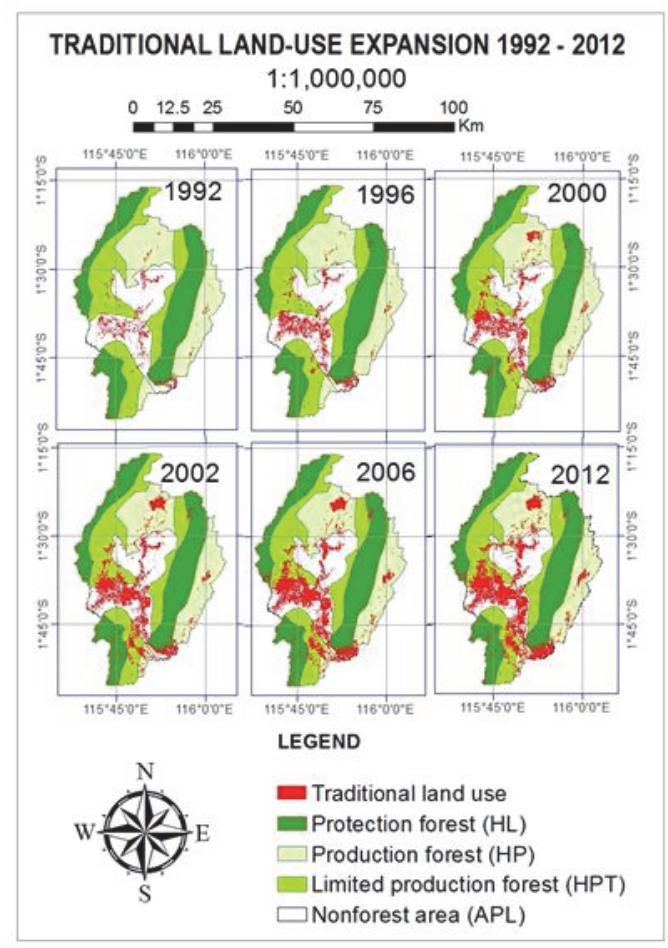

Figure 3. 4. Spatial distribution of traditional land-use expansion from 1992 to 2012. 


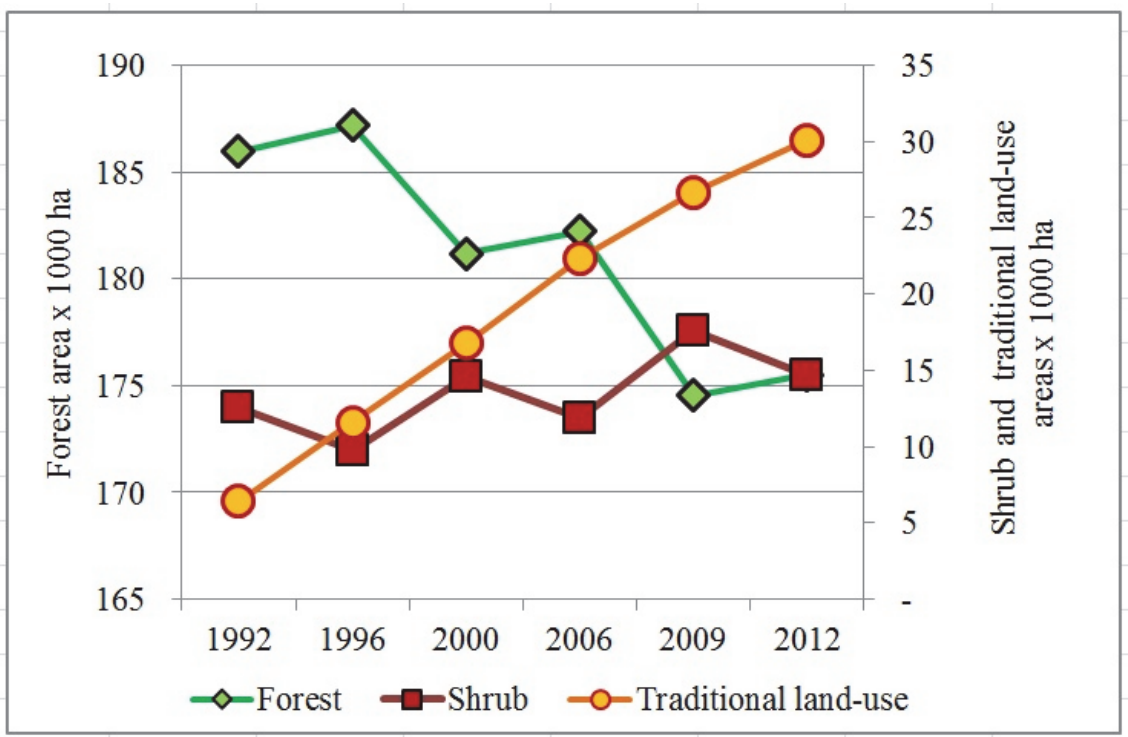

Figure 3. 5. Trends in land cover and land-use change from 1992 to 2012.

In contrast to the trend in agriculture, which consistently increases, the trend in both forest and shrub cover shows an alternating increase and decrease every fourth and sixth year (Figure 3.5). This finding reflects a sequence process of forest recovery from abandoned agricultural land returning to shrub and from shrub to secondary forest as a characteristic of a traditional shifting agricultural system. In the ninth and tenth years after being abandoned and covered by secondary forest, the land is again reopened. These results are consistent with the results of our social surveys and interviews with farmers in which the average fallow period is 10 years.

The resulting factor map analysis shows that traditional land-use expansion occurs mainly on slightly sloped areas. In the period 2000-2012, the majority $(80 \%)$ of land-use conversion was located on slopes under $10 \%, 17 \%$ on slopes of $10-25 \%$ and only $3 \%$ on slopes above $25 \%$.

Traditional land-use expansion generally starts from villages and the periphery of agricultural areas. The agricultural lands were located $0-8 \mathrm{~km}$ from the villages. Fifty five percent were concentrated between 1 and $3 \mathrm{~km}$, and $25 \%$ were located between 3 and $5 \mathrm{~km}$ (Figure 3.6). However, few locations were situated far from the village and the agricultural periphery. 


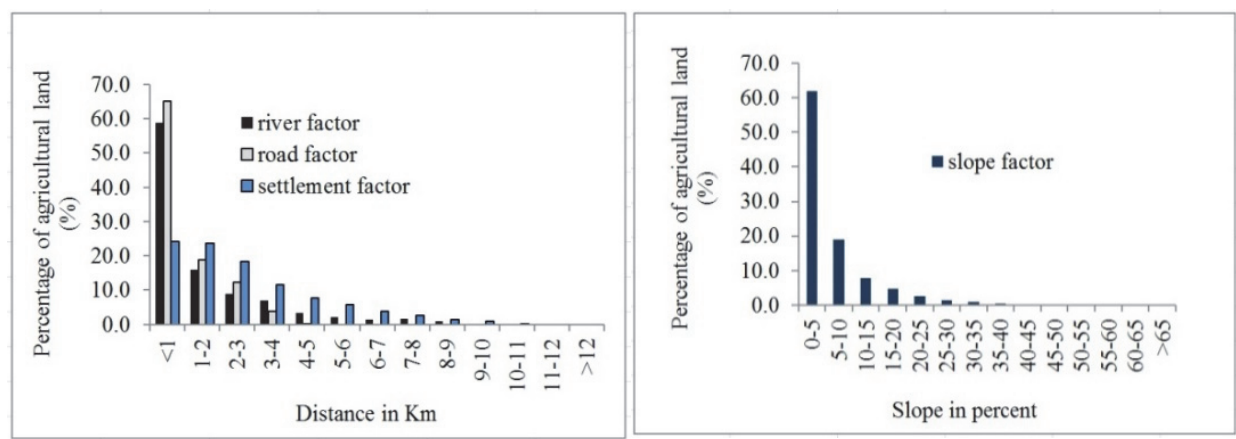

Figure 3. 6. Distribution of traditional expansion based on slope of land and distance to the river, the road, and the settlement

With respect to distance to the main road, $87 \%$ of new traditional land-use was located less than $1 \mathrm{~km}$, and $12 \%$ occurred between 1 and $2 \mathrm{~km}$. There was no agricultural activity farther than $4 \mathrm{~km}$ from the river; $67 \%$ was located within a radius of less than $1 \mathrm{~km}$.

In terms of correlation between deforestation rate and cultural background, Table 3.5 shows the location and distribution of deforestation and deforestation per capita per year in three sampled communities with different cultural backgrounds.

Tabel 3. 5. Deforestation per capita/year in three communities with different cultural backgrounds

\begin{tabular}{lllll}
\hline Communities & $\begin{array}{l}20 \text { years } \\
\text { deforestation (ha) }\end{array}$ & $\begin{array}{l}\text { Population } \\
\text { Rantau Buta-Rantau }\end{array}$ & $\begin{array}{l}\text { Deforestation (ha) } \\
\text { per capita/year }\end{array}$ & $\begin{array}{l}\text { Forest designation } \\
\text { Layung }\end{array}$ \\
Swan Slutung & 1556 & 343 & 0.14 & Production forest \\
Muluy & 128 & 651 & 0.12 & Production forest \\
Total & 2624 & 128 & 0.05 & Protection forest \\
\hline
\end{tabular}

In Table 3.5, deforestation per capita in Muluy is lower than in the other two villages. The Muluy people (indigenous Dayak Paser) are more reluctant to adopt new farming systems, which require more labor, time, and production inputs than traditional systems do. In general, Muluy people grow annual upland rice on a single parcel for 3 years and then abandon the land for 1015 years. Deforestation is lower in Muluy than in Rantau Layung and Rantau Buta, due to the strict ADAT regulations governing their farming activities and gathering of forest products.

Meanwhile, people from Java and Sulawesi living in Swan Slutung have more experience in intensified farming than do the indigenous and local migrants from Kalimantan. On the other hand, Rantau Buta and Rantau Layung, consisting of the Banjar people and indigenous Dayak Paser, have started planting permanent crops such as rubber and oil palm. The Banjar people 
have more financial capital, knowledge and experience. These results support our hypothesis that different cultures will have different strategies and behaviors. Yet, the migrant and indigenous communities do exchange knowledge about farming systems.

Figure 3.7 shows a map of forest designation and traditional-land use areas of the ADAT forests of Muluy and Rantau Layung. The ADAT communities divide ADAT forests into several functions using their own language: Strat (area designated for houses and other facilities), Alas ADAT and Alas Tuo (restricted forest areas forbidden for swidden activities), Alas Nareng and Alas Burok (reserved forest areas for agricultural activities), Awa Pengeramu (communal forest for fruit trees and wood), Awa Ngumo and Awa Penyekulo (areas designated for agricultural activities to produce staple foods). In Figure 3.7, we can see that in general, ADAT systems designate land in line with the Ministry of Forestry.

From interpretations of the ADAT map (Figure 3.7) supported by series of field visits, we conclude that in general, ADAT people have a sustainable system for utilizing their forests. In Rantau Layung Forest, awa ngumo, awa penyekulo, and awa pengeramu forests are situated in gentle-sloped production forests. Alas ADAT and alas nareng are situated in protection forests and steep-sloped production forests. Cultivated areas from 1992 to 2012 were consistently located in Awa Ngumo and Awa Penyekulo, areas designated for agriculture (Figure 3.7). Likewise, in Muluy Forest in the middle of the Mount Lumut Protection Forest, people have been conducting subsistence shifting cultivation for years, but only in limited areas close to roads and rivers. However, since 2010, with the boom in oil palm cultivation in the Paser District, a few people have started to expand their agriculture land by opening alas ADAT/alas tuo forest close to the new main road. 


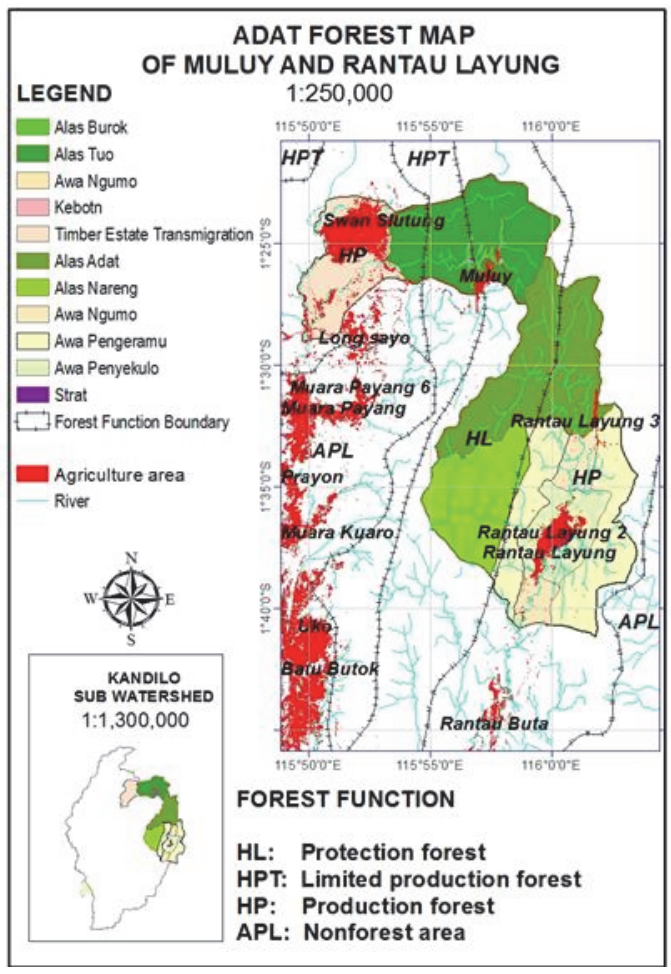

Figure 3. 7. Map of ADAT forest of Muluy and Rantau Layung

\subsubsection{Projected traditional land-use expansion and deforestation}

To determine the level of confidence in our APM for representing measured experimental data, we validated our numerical and spatial APM. Numerical APM accuracy was determined by comparing the extent of the predicted with the observed traditional land-use expansion for the period 2000 to 2012.

Using numerical APM, the agricultural area in 2012 covered 29,169 ha, $4 \%$ of which was under the observed agricultural area; $96 \%$ accuracy indicates that the growth of the population, GDP and crop productivity are reliable variables for predicting the trend in agricultural development.

Figure 3.8 depicts the spatial distribution of the predictive validity of land-use conversion from nonagricultural area into agricultural area for the period 2000-2012. Using the spatial APM and pixel-by-pixel analysis, we found that $67 \%$ of the observed expansion of traditional land-use into non-agricultural area was accurately predicted. The other $33 \%$ could not be predicted (unpredicted). The result of the validation assessment of the APM is presented in Table 3.6. 
Tabel 3. 6. Validation assessment of APM

\begin{tabular}{lcc}
\hline Category & Area (ha) & Validity (\%) \\
\hline Observed agriculture area for 2012 based on map analysis & 30,090 & \\
Predicted agriculture area for 2012 using numerical APM & 29,169 & 96 \\
Observed land-use conversion based on map analysis & 9170 & \\
Predicted land-use conversion using spatial APM & 10,555 & \\
Location accurately predicted & 6192 & 67 \\
Unpredicted & 2979 & 33 \\
\hline
\end{tabular}

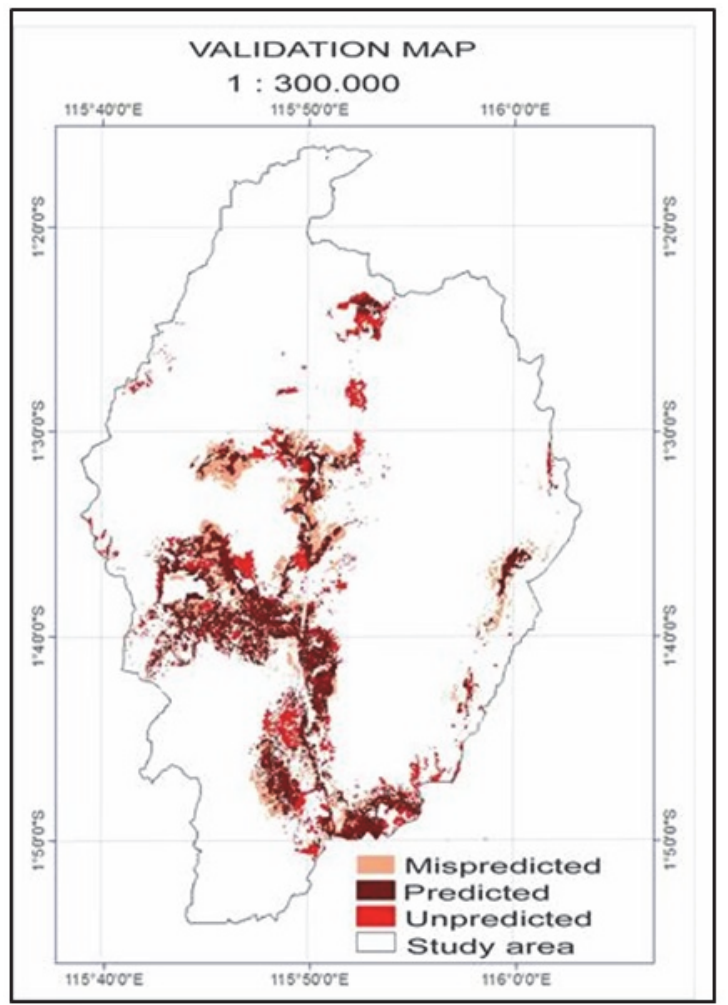

Figure 3. 8. Spatial distribution of the predictions for land-use conversion.

\subsubsection{Traditional land-use projection}

We identified critical elements in the development of our scenarios. Villagers in general were trapped in subsistence farming systems, with low inputs and outputs. They were unable to afford the cost of better farming inputs. Considered as encroachers, there was no farming input subsidy from the regional government such as seed, fertilizer and technology for people living inside the forest. Relying only on the natural fertility of the land, production of upland rice decreased by almost half for the second consecutive year. As a consequence, when productivity decreased in the second and third year, farmers sought new areas to cultivate. In general, their main concerns in deciding which particular locations to cultivate were distance from village, 
slope and accessibility. Relating regional government absenteeism to low productivity underlies the assumption of crop productivity in scenarios 1 and 2. Based on interviews, planting upland rice has been part of the local culture. Farmers will always plant upland rice using shifting cultivation although they have enough money to buy rice from the local market as found in previous studies in other areas (Hariyadi and Ticktin 2012). Shifting cultivation is not only an activity for producing food, but also part of the culture for maintaining a relationship among and between the community and nature.

The results of our 25-year projection are presented in Tables 3.7, 3.8 and 3.9 and Figure 3.9. For the BAU scenario, traditional land-use will expand by $201 \%$ in 25 years at a rate of $1.4 \%$ per year. Thirty six percent of the new land will be situated in forest areas, mainly in permanent production and limited production forest.

Tabel 3. 7. Agricultural productivity in 2037

\begin{tabular}{lcccccc}
\hline \multirow{3}{*}{ Scenarios } & \multicolumn{2}{c}{ Food crops } & \multicolumn{2}{c}{ Oil Palm } & \multicolumn{2}{c}{ Rubber } \\
\cline { 2 - 7 } & $\begin{array}{c}\text { Productivity } \\
\text { (tons/ha) }\end{array}$ & $\begin{array}{c}\text { Increase } \\
(\%)\end{array}$ & $\begin{array}{c}\text { Productivity } \\
\text { (tons/ha) }\end{array}$ & $\begin{array}{c}\text { Increas } \\
\text { e (\%) }\end{array}$ & $\begin{array}{c}\text { Productivity } \\
\text { (tons/ha) }\end{array}$ & Increase (\%) \\
\hline Existing & 0.6 & 0 & 3.6 & & 0.48 & 21 \\
Unexpected & 0.6 & 0.35 & 21 & 0.58 & 77 \\
Expected/BAU & 0.6 & 0 & 6.84 & 90 & 0.85 & 219 \\
Visionary & 1.52 & 153 & 10.54 & 193 & 1.53 & \\
\hline
\end{tabular}

Tabel 3. 8. Agricultural area in 2037

\begin{tabular}{|c|c|c|c|c|c|c|c|c|}
\hline \multirow[b]{2}{*}{ Scenarios } & \multicolumn{2}{|c|}{ Food crops } & \multicolumn{2}{|c|}{ Oil palm } & \multicolumn{2}{|c|}{ Rubber } & \multicolumn{2}{|c|}{ Total } \\
\hline & Area (ha) & $\begin{array}{c}\text { Increase } \\
(\%)\end{array}$ & $\begin{array}{l}\text { Area } \\
\text { (ha) }\end{array}$ & $\begin{array}{l}\text { Increas } \\
\text { e }(\%)\end{array}$ & $\begin{array}{l}\text { Area } \\
\text { (ha) }\end{array}$ & $\begin{array}{c}\text { Increase } \\
(\%)\end{array}$ & Area (ha) & $\begin{array}{c}\text { Increase } \\
(\%)\end{array}$ \\
\hline Existing & 27,147 & & 1,444 & & 1,449 & & 30,090 & \\
\hline Unexpected & 106,241 & 291 & 9,892 & 585 & 10,829 & 647 & 126,962 & 322 \\
\hline Expected/BAU & 76,631 & 182 & 6,349 & 340 & 7,577 & 423 & 90,557 & 201 \\
\hline Visionary & 28,343 & 4 & 8,950 & 520 & 8,780 & 506 & 46,073 & 53 \\
\hline
\end{tabular}

In the sustainable scenario, due to improved farming systems, forestry law enforcement synergized with the revitalization of ADAT law and enactment of the forest alteration policy, the model predicts that traditional landuse in 2037 will have expanded by $53 \%$, with $10 \%$ of that new land in forest areas. In this scenario, the 2012 productivity of upland rice, rubber and oil palm will triple.

To map spatial distribution of land-use conversion and to calculate deforestation, we overlaid the spatial output of APM onto the Designation of Provincial Forest Area and Inland Water, Coastal and Marine Ecosystem of East Kalimantan Province Map. This map divides East Kalimantan Land into 4 designated areas: HPT, HP, HL, and APL. The spatial distribution of future agricultural expansion is presented in Figure 3.9. 


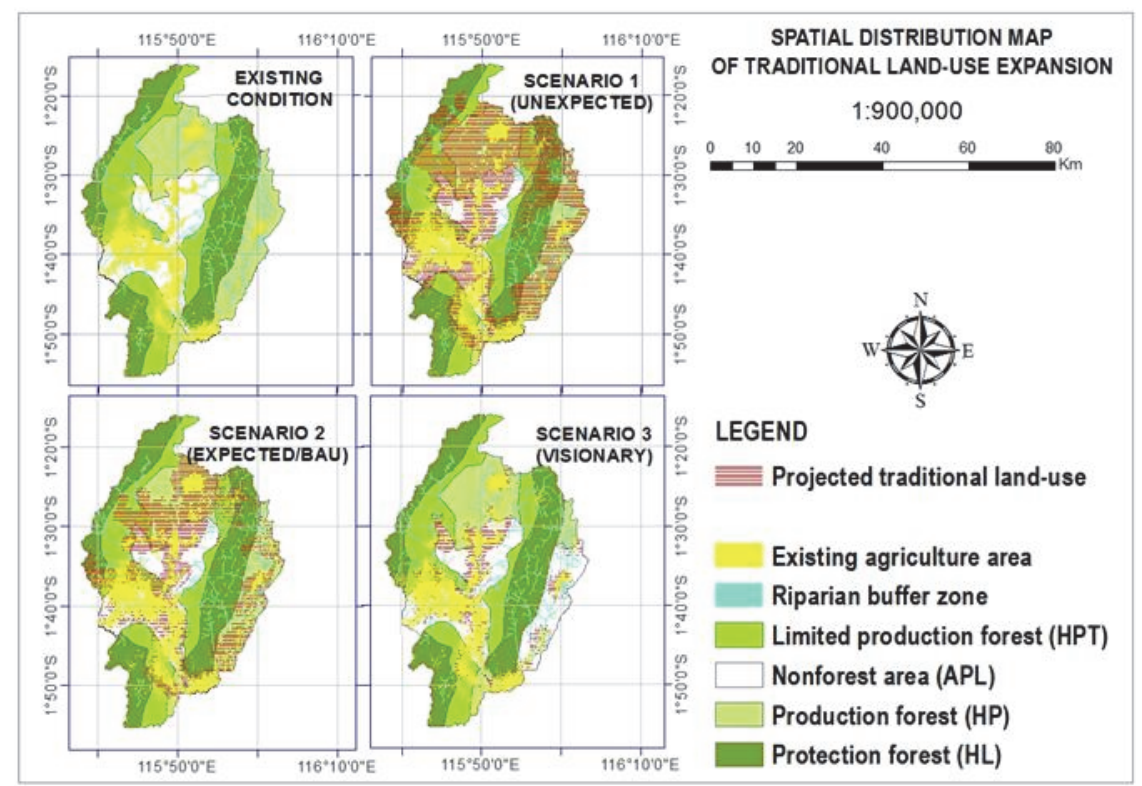

Figure 3. 9. Spatial distribution of agricultural expansion for three different scenarios

In Figure 3.9, we can see that in scenario 1 (unexpected) and scenario 2 (expected/BAU), traditional land-use expanded to all land-use in almost similar proportion. In contrast, scenario 3 (visionary) directed the majority of the traditional land-use expansion to the nonforest area. The distribution of traditional land-use based on forest designation of the three scenarios is presented in Table 3.9.

Tabel 3. 9. Projected traditional land-use expansion and deforestation

\begin{tabular}{|c|c|c|c|c|c|c|c|c|c|}
\hline \multirow{3}{*}{$\begin{array}{l}\text { Forest } \\
\text { designation* }\end{array}$} & \multirow{3}{*}{$\begin{array}{l}\text { Existing } \\
\text { forest (ha) }\end{array}$} & \multicolumn{8}{|c|}{ Traditional land-use (ha) } \\
\hline & & \multicolumn{2}{|c|}{ Baseline } & \multicolumn{2}{|c|}{ Scenario 1} & \multicolumn{2}{|c|}{ Scenario 2} & \multicolumn{2}{|c|}{ Scenario 3} \\
\hline & & 2012 & Def.(\%) & 2037 & Def. (\%) & 2037 & Def.(\%) & 2037 & Def.(\%) \\
\hline HPT & 50,657 & 6,175 & -12.2 & 26,889 & -53.1 & 19,249 & -38.0 & 8,306 & -16.4 \\
\hline HP & 49,549 & 5,764 & -11.6 & 42,963 & -86.7 & 32,605 & -65.8 & 6,868 & -13.9 \\
\hline $\mathrm{HL}$ & 60,708 & 1,563 & -2.6 & 20,598 & -33.9 & 7,422 & -12.2 & 2,059 & -3.4 \\
\hline APL & 45,546 & 16,588 & -36.4 & 36,512 & -80.2 & 31,281 & -68.7 & 28,840 & -63.3 \\
\hline Forest & 160,914 & 13,502 & -8.4 & 90,450 & -56.2 & 59,276 & -36.8 & 17,233 & -10.7 \\
\hline Total & 206,460 & 30,090 & -14.6 & 126,962 & -61.5 & 90,557 & -43.9 & 46,073 & -22.3 \\
\hline
\end{tabular}

*HPT: Limited production forest; HP: Production forest, HL: Protection forest; APL: Nonforest area; Def : Deforestation

\subsection{Discussion}

The engagement of ADAT communities in the sustainable forest management of Indonesia has proven to be reliable. Three scenarios were used to further test the reliability of such engagement. These scenarios (unexpected, expected, and visionary outcomes) emphasize our expectations of future livelihood security, land tenure certainty, and synergizing ADAT law and formal law. 
The spatial analysis shows that traditional land-use expansion increases as slope and distance to villages, roads, and rivers decreases (Figure 3.6). This same pattern is common; farmers first clear flat areas, close to water sources or roads and then move to steeper slopes farther from roads (Avoided Deforestation Partners 2009; Kinnaird et al. 2003; Lambin and Meyfroidt 2010; Ochoa-Gaona 2001; Ochoa-Gaona and Gonza'lez-Espinosa 2000).

However, our data from the factor map analysis support statements that land-use change and forest transition patterns are dynamic (Lambin and Meyfroidt 2010); people's actual behaviors are not always associated with "intentions" and "attitudes" (Holdershaw and Gendall 2008; Lu 1999). Only $2-5 \%$ of the traditional land-use was situated on steep slopes, far from villages, agricultural peripheries, roads and rivers.

This potential for unpredictable behaviour is reflected in the results of our APM validation (Figure 3.8; Table 3.6); 33\% of observed land-use conversion could not be predicted due to their limited relevance of slope and distance factors. However, in terms of accuracy of location, the use of spatial APM in this study was better than the study in Phrao, which reached 53\% (Ato 1996) and in Kutai Barat, which reached 65\% (Hamzah 2012).

Our spatial analysis of three villages showed that sociocultural characteristics, experiences, and farming systems (Table 3.5) can affect deforestation per capita. The lowest deforestation per capita occurred in Muluy communities, in line with the study of (Chi et al. 2013) who mentioned that cultural characteristics of communities are one of the most important factors affecting land-use conversion. Norms, beliefs and traditions are tightly linked to the ways indigenous people manage their forest resources (Mulyoutami et al. 2009; Sasaoka and Laumonier 2012). In the village dominated by ADAT people, ADAT regulations and beliefs concerning the best time to start land clearing, plugging and planting, which areas and trees are forbidden to cut, and how large an area can be utilized per household per planting season are still followed. The ADAT law has governed ADAT forest management for many generations by regulating people's rights of access to forest products, the designation of forestland cleared for agriculture, and the planting or protection of trees in the forest (Butt 2014).

Traditionally, the period of cultivation ends when the soil fertility is exhausted and productivity decreases. Instead of intensifying inputs to raise production, farmers expand their land into forest areas. In forest areas, agriculture cannot be intensified and thus ensure food security and income generation (Brown and Schreckenberg 1998; Grogan et al. 2013). 
For decision-makers, the essential task, however, is how to develop new policies enabling traditional communities to meet their basic needs for an adequate standard of living (such as for sugar, fish, meat, clothes, housing, education), which is equivalent to 1 ton/capita/year of rice without damaging the environment. For villagers whose livelihoods depend on agriculture, the minimum for farm production per household is equivalent to 7.9 tons of upland rice per year.

In the visionary scenario, farming systems are improved in line with consistent law enforcement, synergizing formal law regulating general prohibition and ADAT law regulating daily based norms and activities. Based on our observations of the cultivation areas of the ADAT communities from 1992 to 2012 (Figure 3.7), we came to understand that ADAT people have managed their forest in line with ADAT law.

In the visionary scenario, certain forest areas with slopes under $40 \%$ are given to indigenous communities together with the revitalization of customary rights and ADAT institutions. As a result, in the final year, productivity of food and market crops will increase by 180 and $200 \%$, respectively, compared with the initial year (Table 3.7). Even though rice production is still lower than the district level, it will be sufficient to provide a minimum standard of living. After forest conversion, there is a possibility that villagers could legally have 3-4 ha of land. One hectare for upland rice and 2-3 ha for rubber would be sufficient to provide enough rice for household needs and other food for the whole year. By having more land with secure tenure, local people would be able to improve their farming systems. Two village areas would be excluded from the forest zone starting with the third period. Since both villages will no longer be situated in the forest zone, the regional government will be able to officially support them to improve farming production inputs and technology. However, in Indonesia, communal rights to land are among the most intriguing of concepts (Bakker 2008). In some cases, communal ownership can be subject to forest degradation when local institutions are managed inappropriately (Perez-Verdin et al. 2009). In such a scenario, deforestation can occur, but to a lesser extent compared with the initial deforestation rate, which would be $10.7 \%$ over a 25 -year period (Table 3.9 ) at a rate of $0.4 \%$ per year.

\subsection{Conclusion}

This paper discusses spatial patterns of traditional land-use expansion and deforestation and how physical aspects as well as socioculture and policy affect their dynamics. The evidence indicates that slope and accessibility are important factors affecting traditional land-use expansion. The steeper the slope and the farther the distance, the lower the rate of deforestation. 
However, due to the dynamics of human behavior, some areas of traditional land-use are randomly located, inconsistent with these factors.

The results of the village surveys support our hypotheses concerning the sociocultural aspects of deforestation. Our spatial analysis of three villages shows differences between sociocultural characteristics, experience, and farming practices. The lowest rate of deforestation per capita occurred where customary laws strictly regulate people's activities. Meanwhile, in the more modern communities, deforestation was higher as a consequence of higher financial capital as well as knowledge and experience. Analyzing ADAT forest designation maps and 20 years of traditional farming practices of the ADAT people, we reached the conclusion that ADAT people manage their forest sustainably.

In general, there were similarities between land designated under ADAT law and that under the Ministry of Forestry. The adherence of ADAT law is a key reason that deforestation was controlled.

Since shifting cultivation has been part of ADAT culture for many generations, the solution is not to force them to convert to permanent agricultural systems. Rather, ensuring the security of land rights and assisting in the improvement of their shifting cultivation while moving toward more productive systems, with longer fallows, and providing better farming inputs and technology to maintain soil fertility. In fact, traditional land-use systems are feasible systems when physical constraints make modernization of agriculture impossible (Plieninger et al. 2006).

The essential measures, however, are empowerment of customary law and adaptation of indigenous knowledge in forest management to meet current needs and conditions. Long-term security and short-term consumption of agricultural commodities should be optimized through the combination of land management and local institutional enforcement. Land-use management that enhances farming income while avoiding deforestation and degradation must be promoted, supported by land allocation and implementation of formal laws that respect ADAT law and revitalize ADAT institutions.

Based on our projections, at least three factors decrease deforestation and increase community welfare: (1) improvement of farming practices, (2) land allocation to ensure livelihood security, and (3) law enforcement synergizing formal law and ADAT law to ensure implementation of sustainable land-use management. A combination of the three approaches will result in an increase in crop productivity, sufficient for households to have a minimum standard of living with less deforestation. However, to determine the reliability of our conclusions, further studies and more replication in other locations are needed. 
Finally, instead of developing approaches to stop deforestation, this study explored spatial analytical approaches to provide a better understanding of deforestation in correlation with agricultural expansion. The accuracy of all projections may be subject to question. Different resolutions of spatial data as well as nonspatial data may produce different results. However, by combining spatial models with GIS and field surveys to develop scenarios that are as realistic as possible, we can provide better evidence to help decisionmakers and other stakeholders design what strategies to prevent the projected outcomes.

\section{Acknowledgement}

This study was financially supported with the cooperation between the Tropenbos International Indonesia Program and the Forestry Research and Development Agency of the Indonesian Ministry of Forestry. We thank the people of Muluy, Rantau Buta, Rantau Layung, and Swan Sutung for their support during our fieldwork.

\section{References}

Adams C, Chamlian Munari L, Vliet N, Sereni Murrieta R, Piperata B, utemma C, Spressola-Prado V (2013) Diversifying incomes and losing landscape complexity in Quilombola shifting cultivation communities of the atlantic rainforest (Brazil). Hum Ecol 41(1):119-137. doi:10.1007/s10745-0129529-9

Akinyemi FO (2013) An assessment of land-use change in the Cocoa Belt of south-west Nigeria. Int J Remote Sens 34(8):2858-2875. doi:10.1080/01431161.2012.753167

Angelsen A, Kaimowitz D (2001) Agricultural technology and forests: a recapitulation Agricultural technologies and tropical deforestation. CABI Publishing, Wallingford, pp 383-402

Araujo C, Bonjean CA, Combes JL, Motel PC, Reis EJ (2010) Does land tenure insecurity drive deforestation in the Brazilian Amazon? CERDI, Etudes et Documents (vol E 2010.13): CERDI

Ato VA (1996) Prediction of deforestation using area production model (Master Thesis), International Institute of Aerospace Survey and Earth Science (ITC), Enschede, The Netherlands

Avoided Deforestation Partners (2009) REDD methodological module "Location and quantification of the threat of unplanned baseline deforestation" version 1.0, April 2009. Avoided Deforestation Partners.org

Badan Planologi Kehutanan (2007) Identifikasi Desa Dalam Kawasan Hutan 2007. Kerjasama Pusat Rencana dan Statistik Kehutanan, Departemen 
Kehutanan dengan Direktorat Statistik Pertanian, Badan Pusat Statistik, Jakarta

Bakker L (2008) "Can We Get Hak Ulayat?": land and community in Pasir and Nunukan, East Kalimantan. Center for Southeast Asia Studies. Center for Southeast Asia Studies, UC Berkeley. Retrieved from: http://escholarship.org/uc/item/5pj3z2jr

BAPPEDA Kalimantan Timur (2008) Rencana Pembangunan Jangka Panjang Daerah Propinsi Kalimantan Timur 2008. BAPPEDA Kalimantan Timur, Samarinda

BAPPENAS (2005) Proyeksi Pertumbuhan Penduduk Indonesia 2000-2025. Jakarta: Badan Perencanaan Pembangunan Nasional, Badan Pusat Statistik, dan United Nation Population Fund

Barbier EB (2004) Explaining agricultural land expansion and deforestation in developing countries. Am J Agric Econ 86(5):1347-1353. doi:10.1111/j.0002-9092.2004.00688.x

Blaser J (2010) Forest law compliance and governance in tropical countries: a region-by-region assessment of the status of forest law compliance and governance in the tropics, and recommendations for improvement. FAO and ITTO

Boafo J (2013) The impact of deforestation on forest livelihoods in Ghana. Backgrounder Africaportal. http://www.africaportal.org/sites/default/files/Africa\%20Portal\%20Back grounder\%20No.\%2049.pdf. Cited 24 Agustus 2014

Bottazzi P, Dao H (2013) On the road through the Bolivian Amazon: a multilevel land governance analysis of deforestation. Land Use Policy 30(1):137-146. doi:10.1016/j.landusepol.2012.03.010

Boucher D, Elias P, Lininger K, May-Tobin C, Roquemore S, Saxon E (2011) The root of the problem: what's driving tropical deforestation today?. Tropical Forest and Climate Initiative, Union of Concerned Scientists, Cambridge BPS Kabupaten Pasir (2011) Kabupaten Pasir Dalam Angka 2011. Badan Pusat Statistik Kabupaten Pasir, Tanah Grogot

Branca G, McCarthy N, Lipper L, Jolejole MC (2011) Climate-smart agriculture: a synthesis of empirical evidence of food security and mitigation benefits from improved cropland management Mitigation of Climate Change in Agriculture Series 3. Food and Agriculture Organization of the United Nations, Rome

Brown D, Schreckenberg K (1998) Shifting cultivators as agents of deforestation: assessing the evidence. Nat Resour Perspect 29:1-14

Butt S (2014) Traditional land rights before the Indonesian Constitutional Court. LEAD J 10(1):59-73

Cahyadi $F$ (2014) Indigenous people as victim of law on the prevention and eradication of forest destruction. http://www.aman.or.id/en/2014/11/21/indigenous-people-as-victim-of- 
law-onon-the-revention-and-eradication-of-forest-destruction/Cited. 15 Jan 2015

Carr D (2008) Farm households and land use in a core conservation zone of the Maya Biosphere Reserve, Guatemala. Hum Ecol. 36(2):231-248. doi:10.1007/s10745-007-9154-1

Chi V, Rompaey A, Govers G, Vanacker V, Schmook B, Hieu N (2013) Land transitions in Northwest Vietnam: an integrated analysis of biophysical and socio-cultural factors. Hum Ecol. 41(1):37-50. doi:10.1007/s10745-013-9569-9

Chomitz KM, Buys Piet, De Luca Giacomo, Thomas TS, Wertz-Kanounnikoff S (2007) At loggerheads? Agricultural expansion, poverty reduction, and environment in the tropical forests. A World Bank Policy Research Report. The World Bank, Washington, DC

Chun J (2014) A legal approach to induce the traditional knowledge of forest resources. For Policy Econ 38:40-45. doi:10.1016/j. forpol.2012.07.006

Damnyag L, Saastamoinen O, Blay D, Dwomoh FK, Anglaaere LCN, Pappinen A (2013) Sustaining protected areas: identifying and controlling deforestation and forest degradation drivers in the Ankasa Conservation Area, Ghana. Biol Conserv 165:86-94. doi:10.1016/j.biocon.2013.05.024

Direktorat Jenderal Planologi Kehutanan (2009) Identifikasi Desa Dalam Kawasan Hutan 2009. Kerjasama Departemen Kehutanan dengan Badan Pusat Statistik, Jakarta

Entwisle B, Rindfuss RR, Walsh SJ, Page PH (2008) Population growth and its spatial distribution as factors in the deforestation of Nang Rong, Thailand. Geoforum 39(2):879-897. doi:10.1016/j.geoforum.2006.09.008

Epule ET, Peng C, Lepage L, Chen Z (2014) Policy options towards deforestation reduction in Cameroon: an analysis based on a systematic approach. Land Use Policy 36:405-415. doi:10.1016/j.landusepol.2013.09.004

FAO (2011) The state of the world's land and water resources for food and agriculture (SOLAW)-managing systems at risk. Summary Report. Rome and Earthscan, London. Food and Agriculture Organization of the United Nations

Fearnside PM (2001) Land-tenure issues as factors in environmental destruction in BrazilianAmazonia: the case of Southern Para'. World Dev 29(8):1361-1372. doi:10.1016/S0305-750X(01)00039-0

Foley JA, DeFries R, Asner GP, Barford C, Bonan G, Carpenter SR, Chapin FS, Coe MT, Daily GC, Gibbs HK, Helkowski JH, Holloway T, Howard EA, Kucharik CJ, Monfreda C, Patz JA, Prentice IC, Ramankutty N, Snyder PK (2005) Global consequences of land use. Science 309(5734):570574. doi:10.1126/science. 1111772 
Forest Science Division (2001) The area production model (APM) in numerical and spatial context: case studies and exercises. Forest Science Division, International Institute for Aerospace Survey and Earth Science, Enschede

Gaveau DLA, Linkie M, Suyadi Levang P, Leader-Williams N (2009) Three decades of deforestation in southwest Sumatra: effects of coffee prices, law enforcement and rural poverty. Biol Cons 142(3):597-605. doi:10.1016/j.biocon.2008.11.024

Geist HJ, Lambin EF (2002) Proximate causes and underlying driving forces of tropical deforestation: tropical forests are disappearing as the result of many pressures, both local and regional, acting in various combinations in different geographical locations. Bioscience 52(2):143-150. doi:10.1641/0006-3568(2002)052[0143:PCAUDF]2.0.CO;2

Gonzales Bernaldez F (1991) Ecological consequences of the abandonment of traditional land use systems in central Spain. In: Baudry J, Bunce RGH (eds) Land abandonment and its role in conservation. CIHEAM, Zaragoza, pp 23-29

Grogan K, Birch-Thomsen T, Lyimo J (2013) Transition of shifting cultivation and its impact on people's livelihoods in the Miombo Woodlands of Northern Zambia and South-Western Tanzania. Hum Ecol 41(1):77-92. doi:10.1007/s10745-012-9537-9

Hamzah $\mathrm{H}$ (2012) Modeling of tropical forest conversion to oil palm expansion using area production model: a case study of Nyuatan watershed. University of Twente Faculty of Geo-Information and Earth Observation (ITC), Enschede

Hariyadi B, Ticktin T (2012) From shifting cultivation to Cinnamon agroforestry: changing agricultural practices among the Serampas in the Kerinci Seblat National Park, Indonesia. Hum Ecol 40(2):315-325. doi:10.1007/s10745-012-9481-8

Hartanto H, Rangan H, Thorburn C, Kull C (2008) Strategic engagement and dynamic adaptation: customary forest management in Keribci, Central Sumatra, Indonesia. Paper presented at the 12th Biennial Conference of the International Association for the Study of Commons, England

Heinimann A, Hett C, Hurni K, Messerli P, Epprecht M, Jorgensen L, Breu T (2013) Socio-economic perspectives on shifting cultivation landscapes in Northern Laos. Hum Ecol 41(1):51-62. doi:10.1007/s10745-0139564-1

Heryani E, Grant C (2004) Land administration in Indonesia. Paper presented at the 3rd FIG regional conference, Jakarta, Indonesia Holdershaw J, Gendall P (2008, 9-11 July 2008) Understanding and predicting human behaviour. Paper presented at the ANZCA08: communication conference: power \& place, Wellington, New Zealand

Hussin YA, Bode J, Gier AD (1995) The crystal globe: a GIS-based operational area production model. Paper presented at the $16^{\text {th }}$ Asian conference on 
remote sensing, Suranaree University of Technology, Nakhon Ratchasima, Thailand

IWGIA (2011) Update 2011-Indonesia. The Indigenous World Asia. http://www.iwgia.org/regions/asia/indonesia/43-engregions/asia/871update-2011-indonesia. Cited 31 March 2015

Jakeman T, Chen S, Newham L, Pollino C (2009) Modelling and Adaptive Environmental Management. In: Allan C, Stankey G (eds) Adaptive environmental management. Springer, Dordrecht, pp 173-187

Kementerian Kehutanan (2011) Statistik Kehutanan 2010. Kementerian Kehutanan, Jakarta

Kinnaird MF, Sanderson EW, O'Brien TG, Wibisono HT, Woolmer G (2003) Deforestation trends in a tropical landscape and implications for endangered large mammals Tendencias de Deforestacio'n en un Paisaje Tropical y Sus Implicancias para Mamı'feros Grandes en Peligro. Conserv Biol 17(1):245-257. doi:10.1046/j.15231739.2003.02040.x

Lambin EF, Meyfroidt P (2010) Land use transitions: socio-ecological feedback versus socio-economic change. Land Use Policy 27(2):108118. doi:10.1016/j.landusepol.2009.09.003

Lininger K (2011) Small-scale farming and shifting cultivation. In: Boucher D, Elias P, Lininger K, May-Tobin C, Roquemore S, Saxon E (eds) The root of the problem what's driving tropical deforestation today?. Union of Concerned Scientists, Cambridge, pp 89-94

Lu M (1999) Do people move when they say they will? Inconsistencies in individual migration behavior. Popul Environ 20(5):467-488. doi:10.1023/a:1023365119874

Mattsson E, Persson UM, Ostwald M, Nissanka SP (2012) REDD ? readiness implications for Sri Lanka in terms of reducing deforestation. J Environ Manag 100:29-40. doi:10.1016/j.jenvman.2012.01.018

May-Tobin C (2011) Small-scale farming and shifting cultivation. The root of the problem: What's driving tropical deforestation today? Tropical Forest and Climate Initiative, Union of Concerned Scientists, Cambridge, pp 89-94

Mertens B, Sunderlin WD, Ndoye O, Lambin EF (2000) Impact of macroeconomic change on deforestation in South Cameroon: integration of household survey and remotely-sensed data. World Dev 28(6): 983-999

Mertz $O$ (2009) Trends in shifting cultivation and the REDD mechanism. Curr Opin Environ Sustain 1(2):156-160. doi:10.1016/j.cosust.2009.10.002

Mulyoutami E, Rismawan R, Joshi L (2009) Local knowledge and management of simpukng (forest gardens) among the Dayak people in East Kalimantan, Indonesia. For Ecol Manag. 257(10):2054-2061. doi:10.1016/j.foreco.2009.01.042 
Ochoa-Gaona S (2001) Traditional land-use systems and patterns of forest fragmentation in the highlands of Chiapas, Mexico. Environ Manag 27(4):571-586. doi:10.1007/s002670010171

Ochoa-Gaona S, Gonza' lez-Espinosa M (2000) Land use and deforestation in the highlands of Chiapas, Mexico. Appl Geogr 20(1):17-42. doi:10.1016/S0143-6228(99)00017-X

Palm CA, Smukler SM, Sullivan CC, Mutuo PK, Nyadzi GI, Walsh MG (2010) Identifying potential synergies and trade-offs for meeting food security and climate change objectives in sub-Saharan Africa. Proc Natl Acad Sci. doi:10.1073/pnas.0912248107

Pasgaard M (2013) The challenge of assessing social dimensions of avoided deforestation: examples from Cambodia. Environ Impact Assess Rev 38:64-72. doi:10.1016/j.eiar.2012.06.002

Pedoman Penentuan Daya Dukung Lingkungan Hidup dalam Penataan Ruang Wilayah, Permen No. 17 Tahun 2009 Stat (2009)

Perez-Verdin G, Kim YS, Hospodarsky D, Tecle A (2009) Factors driving deforestation in common-pool resources in northern Mexico. J Environ Manag 90(1):331-340. doi:10.1016/j.jenvman.2007.10.001

Pfeffer MJ, Schlelhas JW, DeGloria SD, Gomez J (2005) Population, conservation, and land use change in Honduras. Agr Ecosyst Environ 110(1-2):14-28. doi:10.1016/j.agee.2005.05.003

Plieninger T, Ho"chtl F, Spek T (2006) Traditional land-use and nature conservation in European rural landscapes. Environ Sci Policy 9(4):317-321. doi:10.1016/j.envsci.2006.03.001

Pouliot M, Treue T, Obiri BD, Ouedraogo B (2012) Deforestation and the limited contribution of forests to rural livelihoods in West Africa: evidence from Burkina Faso and Ghana. Ambio 41(7):738-750. doi:10.1007/s13280-012-0292-3

Purnamasari RS (2010) Dynamics of small-scale deforestation in Indonesia: examining the effects of poverty and socio-economic development. Paper presented at the XIII World Forestry Congress, Rome

Ratnasari (2013, Juni 2013). Pengelolaan DAS Berbasis Masyarakat. Buletin RMI 10-11

Rudel TK, Defries R, Asner GP, Laurance WF (2009) Changing drivers of deforestation and new opportunities for conservation. Conserv Biol 23(6): 1396-1405. doi:10.1111/j.1523-1739.2009.01332.x

Rudel TK, Schneider L, Uriarte M (2010) Forest transitions: an introduction. Land Use Policy 27(2):95-97. doi:10.1016/j.land usepol.2009.09.021

Sandewall M, Nilsson NE (2001) The area production model: a tool and concept for sustainable land-use and forest-resource management. J Environ Manag 62(4):415-427. doi:10.1006/jema. 2001.0450

Sasaoka M, Laumonier Y (2012) Suitability of local resource management practices based on supernatural enforcement mechanisms in the local social-cultural context. Ecol Soc. doi:10.5751/ES-05124-170406 
Sawathvong S (2004) Experiences from developing an integrated land-use planning approach for protected areas in the Lao PDR. For Policy Econ 6(6):553-566. doi:10.1016/S1389-9341(03) 00005-4

Seidenberg C, Mertz O, Kias MB (2003) Fallow, labour and livelihood in shifting cultivation: implications for deforestation in northern Lao PDR. Dan J Geogr 103(2):71-80

Shearman PL, Ash J, Mackey B, Bryan JE, Lokes B (2009) Forest conversion and degradation in Papua New Guinea 1972-2002. Biotropica 41(3):379-390. doi:10.1111/j.1744-7429.2009.00495.x

Suhari I (2015) Perbaikan Statistik Beras. 29 Mei 2015. https://indonesiana.tempo.co/read/41871/2015/05/29/iswadi.didi/perb aikan-statistik-beras

Susana, Ochoa-Gaona (2011) Traditional land-use systems and patterns of forest fragmentation in the highlands of Chiapas, Mexico. Environ Manag 27(4):571-586

Tachibana T, Nguyen TM, Otsuka K (2001) Agricultural Intensification versus extensification: a case study of deforestation in the Northern-Hill Region of Vietnam. J Environ Econ Manag 41(1):44-69. doi:10.1006/jeem.1998.1131

Tomich TP, van Noordwjik M, Budidarsono S, Gillison AN, Kusumanto T, Murdiyarso D, Stolle F, Fagi AM (2001) Agricultural intensification, deforestation, and the environment: assessing tradeoffs in Sumatra, Indonesia. Tradeoffs or synergies? Agricultural intensification, economic development, and the environment. CAB International, Wallingford, pp 221-244

Tropenbos International Indonesia (2006) Penilaian Ekonomi Sumberdaya Hutan Lindung Gunung Lumut, Kabupaten Paser, Kalimantan Timur (vol TE-06/TBI Indonesia/05-I). Tropenbos International Indonesia dan Greenomics Indonesia, Bogor

Verburg PH, Rounsevell MDA, Veldkamp A (2006) Scenario-based studies of future land use in Europe. Agric Ecosyst Environ 114(1):1-6. doi:10.1016/j.agee.2005.11.023

Wangpakapattanawong P, Kavinchan N, Vaidhayakarn C, Schmidt-Vogt D, Elliott S (2010) Fallow to forest: applying indigenous and scientific knowledge of swidden cultivation to tropical forest restoration. For Ecol Manag 260(8):1399-1406. doi:10.1016/j.foreco.2010.07.042

Wa"tzold F, Dreschsler M, Amstrong CW, Baumga"rtner S, Grim V, Huth A, Wissel C (2006) Ecological-economic modeling for biodiversity management: potential, pitfalls, and prospects.

Conserv Biol 20(4):1034-1041. doi:10.1111/j.1523-1739.2006.00353.x

Wijaya T (2014). Indonesia Darurat Masyarakat ADAT. Kenapa? http://www.mongabay.co.id/2014/10/01/indonesia-daruratmasyarakat-ADAT-kenapa/. Cited 31 Maret 2015 
Wollenberg E, Edmunds D, Buck L (2000) Anticipating change: scenarios as a tool for adaptive forest management: a guide. CIFOR, Bogor

Xiao YQ, Wei LJ, Zhou RJ (2001) Simulating deforestation of Nepal by area production model. J For Res 12(1):47-50. doi:10.1007/bf02856800

Yanuariadi T (1999) Sustainable land allocation: GIS-based decision support for industrial forest plantation development in Indonesia. (PhD Dissertation), Wageningen, Enschede, The Netherlands.

(ITC Publication Series, No. 71 (Dissertation No. 59))

Yasmi Y, Kelley L, Enters T (2010) Conflict over forests and land in Asia, Impact, causes and management. The Centre for People and Forests, RECOFTC, Bangkok, p 22 


\section{CHAPTER 4}

\section{DO TRADITIONAL KNOWLEDGE AND ADAT LAW STILL EXIST? \\ VERYFYING INDIGENEITY USING \\ REMOTE SENSING AND SPATIAL INFORMATION ${ }^{3}$}

3 This chapter is based on:

Nugroho, H. Y. S. H., Skidmore, A.K, \& Hussin, Y. A. (2019). Do Traditional knowledge and adat law still exist ? Verifying Indigeneity Using Remote Sensing and Spatial Information. Paper submitted to Applied Geography 


\section{Abstract}

The decision of Indonesian's constitutional court in May 2013, to review Law Number 41/1999 on Forestry, marked a significant step forward in its recognition of the rights of ADAT people (Indonesian terminology of indigenous people) to forest. Under the decision, ADAT forest is no longer considered State forest and rights to it should be granted to ADAT communities inhabiting them as long as there is proof of their ADAT status. However, at the implementation level, special measures are required to ascertain who is truly indigenous. Bogus claims of indigeneity and rights to land are not uncommon. This paper examines the verification mechanism employed for spatial analysis to assess traditional knowledge and ADAT law implementation as substantial evidences for ADAT rights recognition to a forest area. We conducted a case study in the Mount Lumut Protection Forest (MLPF) with two groups of ADAT communities living around the forest using image interpretation and spatial analysis supported by socio-economic and cultural analysis. We also assessed the capacity and awareness of ADAT communities to manage their forest. This case study illustrates that in general ADAT people apply ancestral norms, beliefs and traditional knowledge and wisdom in managing their livelihoods and daily life. Nonetheless, increasing necessities of life, better accessibility, and socio-cultural assimilation has changed the ADAT people's behavior towards nature. Holistic approaches in transferring land rights, effective long-term engagement, and revitalization of ADAT law in line with formal law enforcement, are among the essential measures that must be conducted systematically to ensure that the ADAT forest remains and is sustainably managed for the benefit of the ADAT community and the environment.

Keywords: indigeneity; traditional knowledge; ADAT forests; substantial evidence

\subsection{Introduction}

For many generations, indigenous peoples have been reputedly selfsustaining with a strong connection to the forest linked by norms, beliefs and traditions [1-5]. Nevertheless, the widely accepted premise of indigenous peoples is facing serious challenge [6]. It remains difficult to prove who is indigenous and who is not [4,7-10]. Often, there are people who claim to be indigenous peoples using traditional symbols, for personal gain $[6,11]$. The United Nations Permanent Forum on Indigenous Peoples listed three main characteristics of indigenous peoples : 1) a strong link to territories and surrounding natural resources; 2) distinct social, economic or political systems; and 3) distinct language, culture and beliefs [12]. 
In Indonesia, a country with 250 million people and 1,128 ethnic groups, the term 'indigenous' people is associated with different terminology such as 'ADAT community' (masyarakat ADAT) or 'ADAT law-abiding community' (masyarakat hukum ADAT), native people or isolated people. However, the term that is used in legal regulations to define indigenous people is masyarakat hukum ADAT (ADAT law-abiding community) [13-17].

The recent history of ADAT rights recognition in Indonesia began on May 16, 2013, when the Indonesian Constitutional Court issued Decision 35/PUUX/2012 (MK 35) in a Judicial Review of Law No. 41/1999 on Forestry written by AMAN. The MK 35 is an important step forward for ADAT forest users [18]. Under the Constitutional Court directive, ADAT forests located in indigenous territories should no longer be considered State Forests as stipulated in Law No. 41/1999 with the proviso the ADAT community still exists and is recognized by a district regulation $[19,20]$. This decision has opened up new political opportunities for ADAT people to secure territory and resources threatened by State and private interests [21].

AMAN estimated that approximately 40-70 million hectares of Indonesian State forest land should be under customary control $[18,22]$. However, ADAT communities are required to prove their existence supported by sufficient evidence to claim their traditional territory [23, 24]. The Ministry of Home Affairs Regulation 52/2014, stipulates five indicators of indigeneity for official recognition of an ADAT community: (a) history of the ADAT community; (b) ADAT territory; (c) ADAT law; (d) ADAT property relations, inheritance and ADAT artifacts; and (e) a customary governance system.

Looking at the Indonesian existing rules $[13,15,20,25]$, the main approach to validate and verify the existence of ADAT peoples is still focused on a legal approach based on judicial and physical data ('admissible evidences'). There are potential discrepancies between the existence and the implementation of ADAT law. We are concerned that the recognition process will only be an instrument for political persuasion, as mentioned by Kuper [6], rather than being considered a tool for better forest management. We believe that to rely merely on admissible evidences is not enough to prove the indigeneity of ADAT people.

Li, xa [3], define indigeneity as the permanent attachment of a group of people to a fixed area of land, in a way that marks them as culturally distinct. The government of Indonesia, through the Agrarian State Ministry Regulation $5 / 1999$, states that customary rights would be granted to a group of people who are still bound by customary law and apply the rules in their daily living. However, ADAT rights are susceptible to misuse, and claims to ADAT rights 
should be considered on the basis of critical observations employing field research as well as historic data [26].

Using a case study in Mount Lumut Protection Forest (MLPF), this research aimed to assess the historical connection between indigeneity and territory. Territory is often regarded as a key aspect of indigeneity [10, 27]. Here we discuss an approach in the verification process of ADAT rights to a forest territory by assessing substantial evidence to support the existing admissible evidence. Substantial evidence refers to logic and reasonable evidence obtained from adequate and well-controlled investigation to support a conclusion $[28,29]$.

This approach was designed to ensure that the transfer of control rights to forest granted to a certain group of people was not merely a form of rights recognition, but also an attempt to ensure that the ADAT forest remains and is sustainably managed for the benefit of the ADAT community and the environment. We employed spatial analysis supported by socio-economic and cultural analysis to examine traditional knowledge and ADAT law implementation as substantial evidence of indigeneity, 'de facto' recognition, of ADAT people.

We examined the capacity, capabilities and awareness of indigenous peoples and then analyzed our data to assess whether the ADAT people had the capacity to manage their territory sustainably. The two main questions we had to address were: 1 ) do they have the necessary traditional wisdom and knowledge of forest management, and 2) are they aware and committed to the implementation of ADAT law when conducting economic activities in their forest while avoiding land degradation.

\subsection{Methods}

\subsubsection{Research Area}

The study was conducted in Mount Lumut Protection Forest (MLPF), Paser District, in the southeastern part of East Kalimantan Province, Indonesia (Figure 4.1). In 1983, MLPF was designated a Protection Forest (Hutan Lindung) with the main functions to serve as a life support system, and to maintain the hydrological system. Its main river, the Kandilo (181 km long), flows downstream to the flood plain in Tanah Grogot, the capital city of Paser District. Approximately 96 million $\mathrm{m}^{3} /$ year of irrigation and domestic water, valued at US $\$ 7.8$ million per year, is provided by Mount Lumut Protection Forest (Tropenbos International Indonesia 2006). 
The Paser Dayak are an indigenous people, indigenous to Paser District, who live around Mount Lumut. During the last two decades, organized and spontaneous migration of people from outside and inside East Kalimantan have increased the population density and ethnic diversity in the region (Wahyuni, 2011). Currently, the people living in and around MLPF represent three socio-cultural backgrounds: 1) Paser Dayak, 2) Banjar people, immigrants from South Kalimantan, and 3) immigrants from outside Kalimantan, the majority of whom moved from Java and Sulawesi with the central government transmigration program. Subsistence farming with minimum inputs and outputs is the most common agricultural system in the study area. The immigrants originally practiced permanent farming systems of planting food crops (e.g., upland rice, soybeans, maize) and rubber(Nugroho et al., 2017). We observed two communities living in forest areas representing two different cultures: 1) Muluy (an ADAT community), and 2) Rantau Layung (a mixed ADAT and immigrant community). Administratively, Muluy Village comes under the jurisdiction of Swan Slutung Village, the subdistrict of Muara Komam. Rantau Layung Village is located in the subdistrict of Batu Sopang. The present settlement of Muluy is more accessible than Rantau Layung. Muluy is accessible by car the whole year, while Rantau Layung can only be reached by boat during the rainy season.

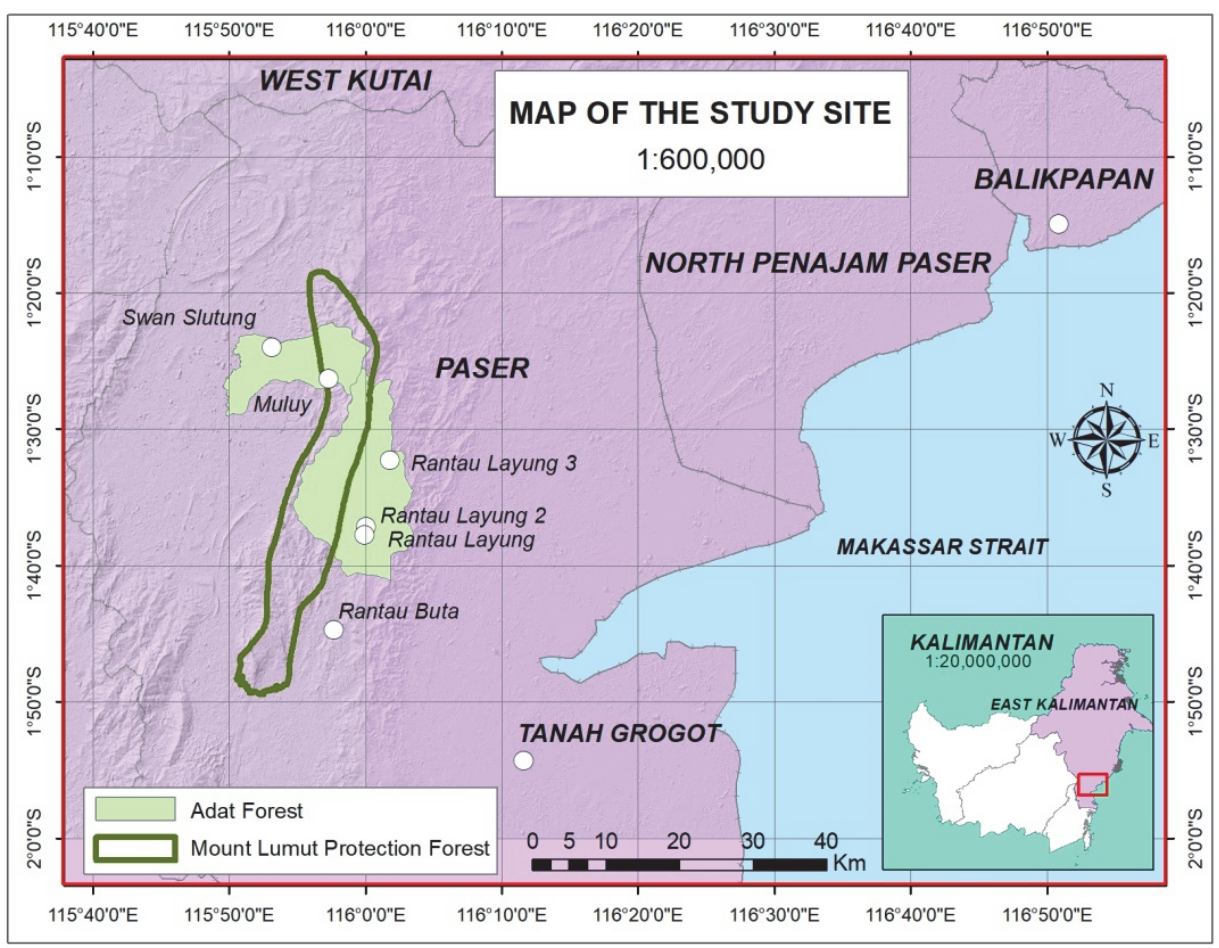

Figure 4.1. Map of the study site. 
The general characteristic of the villages/kampongs are presented in Table 4.1.

Table 4. 1. General characteristic of the villages/kampongs in the study area.

\begin{tabular}{llll}
\hline Villages/kampong & $\begin{array}{c}\text { Villager } \\
\text { composition }\end{array}$ & \multicolumn{1}{c}{$\begin{array}{c}\text { Farming pattern } \\
\text { /commodity }\end{array}$} & Additional activities \\
\hline Rantau Layung & $\begin{array}{l}\text { Dayak Paser } \\
\text { and Banjar }\end{array}$ & $\begin{array}{l}\text { Moved from shifting } \\
\text { cultivation to } \\
\text { permanent } \\
\text { farming/upland rice, } \\
\text { oil palm, rubber } \\
\text { shifting cultivation } \\
\text { /upland rice }\end{array}$ & $\begin{array}{l}\text { Rattan, hunter-gatherer } \\
\text { of deer, bird, honey, } \\
\text { fruit }\end{array}$ \\
Muluy & Dayak Paser & $\begin{array}{l}\text { Hunter-gatherer of } \\
\text { deer, bird, honey, fruit }\end{array}$ \\
\hline
\end{tabular}

\subsubsection{Research Framework}

Figure 4.2 depicts the verification process of the ADAT forest drawing together the analysis of admissible and substantial evidence. In this paper, we focus on analyzing substantial evidence, which consists of: 1) map conformity as an instrument to assess traditional knowledge, and 2) historical land-use patterns as an instrument to assess ADAT law implementation.

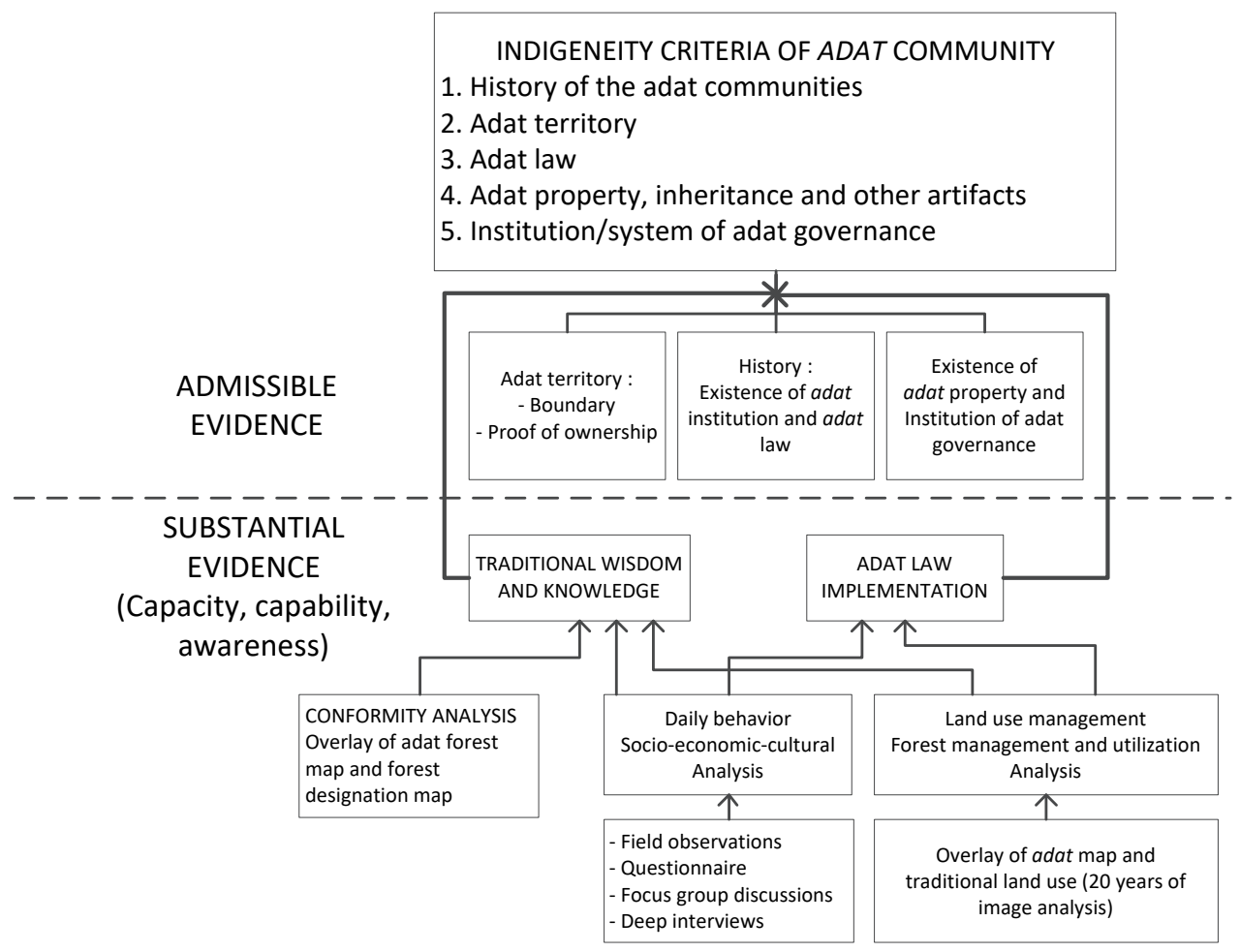

Figure 4.2. Research framework 
We analyzed the map conformity and ADAT land-use expansion patterns to: 1) find out whether the ADAT people have the necessary knowledge of space management and, 2) analyze and compare traditional knowledge (ADAT map) and scientific knowledge (forest designation map). In this paper, traditional knowledge refers to local empirical knowledge, know-how, observations over the centuries and trial and error, maintained by oral communication from generation to generation [33-35], which have evolved by adaptive processes [35, 36]. In contrast to traditional knowledge, scientific knowledge utilizes technology and quantitative methodology, but may lack sufficient long-term experience on the ground in particular areas [34].

\section{a. Conformity analysis}

We conducted spatial analysis to prove whether the ADAT forest zonation and designation meet the specific requirements of (conform to) scientific approach standards in land-use designation. In this case, we employed a map of the designated forest zone (a map designating provincial forest areas and inland water, coastal and marine ecosystems of East Kalimantan Province) produced by the Indonesian Ministry of Forestry as a comparison in the conformity analysis. The Indonesian Ministry of Forestry determined the function-based forest designation, based on degradation risk analysis using at least three criteria: slope, soil erodibility, and rainfall intensity. The conformity analysis also takes into account the restrictions of the use of forestland with slopes greater than $40 \%$ for any agricultural activities [37].

We assume that the capacity, capability and awareness of indigenous peoples of sustainable forest management will be visible, among others, from the way ADAT forest designation has been designed. Our hypothesis was that the zonation process of ADAT forest has considered the biophysical conditions of the areas and is guided by traditional wisdom.

\section{b. ADAT land-use analysis}

To produce land use and land cover maps, we selected satellite images with less than $10 \%$ cloud cover from six different years, taken at approximately four-yearly intervals between 1992-2012, using image processing software (ER-mapper 7.1 and ArcGIS 10.1). To produce an accurate classification, six annual ground checks were conducted between 2009 and 2014. We overlaid each map individually on ADAT forest maps and slope to examine how consistent ADAT people follow ADAT law that regulates land allocation.

The output of this analysis provided an overview of whether the transfer of control over forests contributes to forest preservation or accelerates 
deforestation. In this paper, ADAT land use refers to a combination of shifting cultivation systems of staple crops and traditional systems of rubber and oil palm plantations with very low or no external inputs and low outputs.

A socio-cultural data compilation was carried out between 2009 and 2013. In the last year of the observations (2013), although the MK 35 already existed, there were very few indigenous people aware of the decision. Under these conditions, we assume the information would be objective in accordance with existing conditions. However, achieving accurate socio-cultural data based on direct interviews was challenging since some respondents refrained from openly discussing their 'considered-illegal' forest-based activities (Nugroho et al., 2017). To minimize misinformation and to anticipate some inconsistent responses, especially with regard to farming systems, forest-based income generation, implementation of customary law, and the extent and location of traditional land use, we conducted a series of periodic field visits from 2009 to 2013. Data were collected through interviews using questionnaires, focus group discussions (FGD), informal meetings and dialogues with individuals, and farmland/field visits. To acquire more detailed information on specific issues, we conducted personal interviews with key respondents such as ADAT heads and elders.

\subsection{Results}

\subsubsection{Conformity analysis}

Based on the ADAT maps, the total community forest in Rantau Layung is about 27,300 ha, whereas the total Muluy Forest is only 13,000 ha, including PT. Telaga Mas' 4,900 ha 'HTI-Trans' (integrated industrial forest plantation) concession. The ADAT communities divide ADAT forests into several functions using their own language as described in Table 4.2. 
Table 4. 2. The general characteristic of ADAT forest designation.

\begin{tabular}{|c|c|c|c|c|}
\hline No & $\begin{array}{l}\text { Land-use/ } \\
\text { Designation }\end{array}$ & $\begin{array}{l}\text { Landscape } \\
\text { Characteristic }\end{array}$ & Main function & Land-use pattern \\
\hline 1 & $\begin{array}{l}\text { Strat } \\
\text { (settlement } \\
\text { area) }\end{array}$ & $\begin{array}{l}\text { Flat and undulating, } \\
\text { close to road/river }\end{array}$ & $\begin{array}{l}\text { Settlement, } \\
\text { public facilities }\end{array}$ & $\begin{array}{l}\text { Communal system } \\
\text { based on ADAT } \\
\text { regulation, managed } \\
\text { by ADAT elders }\end{array}$ \\
\hline 2 & $\begin{array}{l}\text { Alas ADAT/ } \\
\text { alas tuo }\end{array}$ & $\begin{array}{l}\text { Sloping to steep, } \\
\text { located far from the } \\
\text { village }\end{array}$ & $\begin{array}{l}\text { hunting area, } \\
\text { restricted } \\
\text { areas/forbidden } \\
\text { for swidden } \\
\text { farming, }\end{array}$ & $\begin{array}{l}\text { Mix of } \\
\text { forest tress Family of } \\
\text { Dipterocarpaceae, } \\
\text { honey tree, Durio } s p \text {, } \\
\text { etc. }\end{array}$ \\
\hline 3 & $\begin{array}{l}\text { Alas nareng/ } \\
\text { alas burok }\end{array}$ & $\begin{array}{l}\text { Flat to gently } \\
\text { sloping, Abandoned } \\
\text { shifting } \\
\text { cultivation area } \\
\text { (fallow), close to the } \\
\text { village, secondary } \\
\text { forest }\end{array}$ & $\begin{array}{l}\text { Reserved areas } \\
\text { for agricultural } \\
\text { activities }\end{array}$ & $\begin{array}{l}\text { Secondary forest, } \\
\text { pioneer tress, Shrub }\end{array}$ \\
\hline 4 & $\begin{array}{l}\text { Awa } \\
\text { pangeramu }\end{array}$ & $\begin{array}{l}\text { Flat, gently sloping, } \\
\text { steep }\end{array}$ & $\begin{array}{l}\text { communal forest } \\
\text { for fruit trees } \\
\text { and wood }\end{array}$ & $\begin{array}{l}\text { Fruits trees, } \\
\text { timber trees, wild } \\
\text { pioneer trees }\end{array}$ \\
\hline 5 & $\begin{array}{l}\text { Awa } \\
\text { ngumo/umo/ } \\
\text { penyekulo }\end{array}$ & $\begin{array}{l}\text { Flat, gently sloping, } \\
\text { steep, usually close } \\
\text { to village, river and } \\
\text { road }\end{array}$ & $\begin{array}{l}\text { Shifting } \\
\text { cultivation, } \\
\text { permanent } \\
\text { farming }\end{array}$ & $\begin{array}{l}\text { Subsistence farming : } \\
\text { Rainfed paddy, rubber } \\
\text { trees, oil palm }\end{array}$ \\
\hline 6 & Kebon & $\begin{array}{l}\text { Flat, gently sloping, } \\
\text { located around the } \\
\text { house }\end{array}$ & $\begin{array}{l}\text { Fruits, } \\
\text { vegetables, } \\
\text { medicinal plants }\end{array}$ & $\begin{array}{l}\text { No tillage, directly } \\
\text { planted from the } \\
\text { seed and/or natural } \\
\text { seedlings }\end{array}$ \\
\hline
\end{tabular}

Source: Interview and ground check 2012-2014, Murniati et al. (2006) and Wahyuni (2011)

For the conformity analysis, we overlaid ADAT forest maps on the map of the Designation of Provincial Forest Area and Inland Water, Coastal and Marine Ecosystems of East Kalimantan Province. This map divides East Kalimantan land into 4 designated areas: HPT (Hutan Produksi Terbatas/Limited Production Forest), HP (Hutan Produksi/Production Forest), HL (Hutan Lindung/Protection Forest), and APL (Area Penggunaan Lain/Non Forest Area). The conformity map is presented in Figure 4.3. Table 4.3 and 4.4 show the distribution of ADAT forests based on slope class. Based on the Designation of Provincial Forest Area and Inland Water, Coastal and Marine Ecosystem of East Kalimantan Province Map, 100\% of ADAT forests of the two communities are situated in forest areas. 


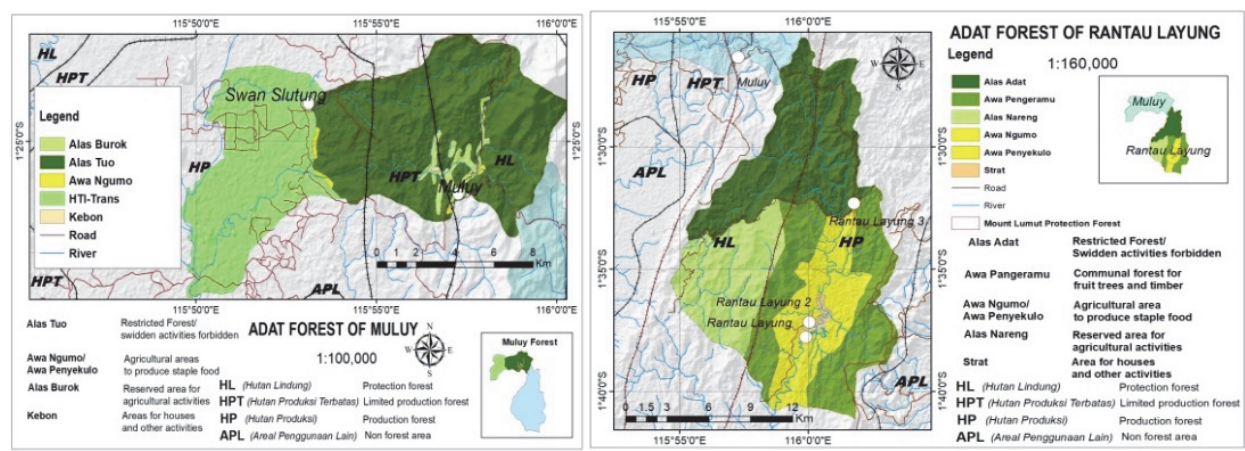

Figure 4. 1. Overlay of ADAT forest and forest designation.

In Table 4.3, we can see that $72 \%$ of awa ngumo (ADAT forest allocated for agricultural) is coincident with production forest and the rest of the $28 \%$ with limited production forest and protection forest, which are not designated for agricultural activities. Meanwhile, $100 \%$ of kebon (area designated for fruit trees and medicinal plants) is situated in limited production forest.

Table 4. 3. Distribution of Muluy ADAT forest based on forest designation.

\begin{tabular}{|c|c|c|c|c|c|c|c|}
\hline \multirow[t]{2}{*}{ Land-use } & \multicolumn{2}{|c|}{$\begin{array}{c}\text { Production } \\
\text { Forest }\end{array}$} & \multicolumn{2}{|c|}{$\begin{array}{c}\text { Limited } \\
\text { Production } \\
\text { Forest } \\
\end{array}$} & \multicolumn{2}{|c|}{$\begin{array}{c}\text { Protection } \\
\text { Forest }\end{array}$} & \multirow[t]{2}{*}{ Total (Ha) } \\
\hline & $\mathrm{Ha}$ & $\%$ & $\mathrm{Ha}$ & $\%$ & $\mathrm{Ha}$ & $\%$ & \\
\hline Alas tuo & 1,385 & 18 & 2,096 & 28 & 4,040 & 54 & 7,521 \\
\hline las burok & - & - & 125 & 31 & 280 & 69 & 405 \\
\hline Awa ngumo & 54 & 72 & 8 & 11 & 13 & 17 & 75 \\
\hline Kebon & - & - & 9 & 100 & - & - & 9 \\
\hline $\begin{array}{l}\text { Timber } \\
\text { estate/Transmigration }\end{array}$ & 4,938 & 100 & - & - & - & - & 4,938 \\
\hline & 6,377 & 49 & 2,238 & 17 & 4,333 & 33 & 12,948 \\
\hline
\end{tabular}

In Table 4.4, $100 \%$ of awa ngumo and awa penyekulo (area designated for agriculture) of Rantau Layung as well as Straat (area designated for settlement and public facilities) are coincident with production forest. The $97 \%$ of alas nareng (reserved area for agricultural activities) is situated in forest the Ministry of Forestry has designated as protection forest. 
Table 4. 4. Distribution of Rantau Layung ADAT forest based on forest designation.

\begin{tabular}{|c|c|c|c|c|c|c|c|}
\hline \multirow[t]{2}{*}{ Land-use } & \multicolumn{2}{|c|}{$\begin{array}{c}\text { Production } \\
\text { Forest }\end{array}$} & \multicolumn{2}{|c|}{$\begin{array}{c}\text { Limited } \\
\text { Production } \\
\text { Forest } \\
\end{array}$} & \multicolumn{2}{|c|}{$\begin{array}{c}\text { Protection } \\
\text { Forest }\end{array}$} & \multirow[t]{2}{*}{$\begin{array}{l}\text { Total } \\
(\mathrm{Ha})\end{array}$} \\
\hline & $\mathrm{Ha}$ & $\%$ & $\mathrm{Ha}$ & $\%$ & $\mathrm{Ha}$ & $\%$ & \\
\hline Alas ADAT & 3,882 & 43 & - & - & 5,045 & 57 & 8,927 \\
\hline Awa pangeramu & 7,234 & 97 & - & - & 223 & 3 & 7,457 \\
\hline Alas nareng & 167 & 3 & - & - & 5,261 & 97 & 5,428 \\
\hline $\begin{array}{l}\text { Awa penyekulo/Awa } \\
\text { ngumo }\end{array}$ & 5,225 & 100 & - & - & - & - & 5,225 \\
\hline Straat & 233 & 100 & - & - & - & - & 233 \\
\hline Total & 16,741 & 61 & - & - & 10,529 & 39 & 27,270 \\
\hline
\end{tabular}

In both communities, agricultural areas (awa ngumo, awa penyekulo, kebon) are located in areas with a slope less than 40\% (Figure 4.4, Table 4.5 and 4.6). Similarly, the area reserved for agricultural activities (awa burok, awa nareng) are generally on a slope of less than $40 \%$.

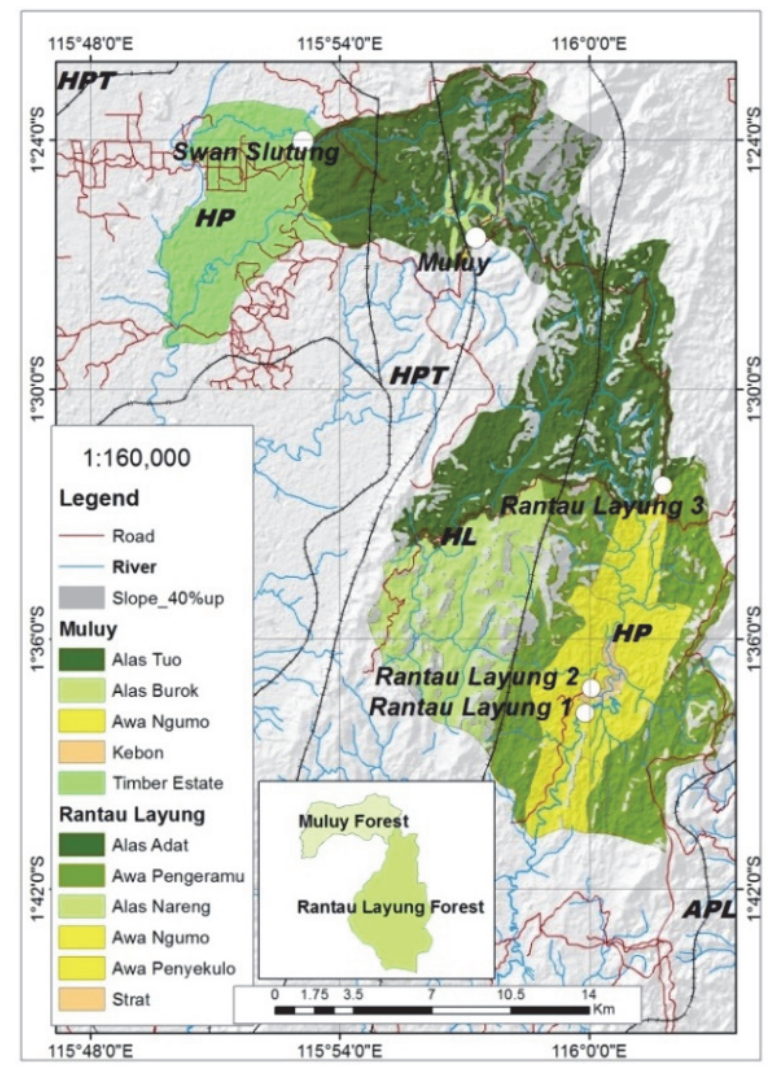

Figure 4. 2. ADAT forest and slope above $40 \%$. 
Table 4. 5. Distribution of Muluy forest based on slope class.

\begin{tabular}{|c|c|c|c|c|c|c|c|c|c|c|}
\hline \multirow{3}{*}{ Slope $\left({ }^{\circ}\right)$} & \multicolumn{10}{|c|}{ Land-use } \\
\hline & \multicolumn{2}{|c|}{ Alas Tuo } & \multicolumn{2}{|c|}{ Alas Burok } & \multicolumn{2}{|c|}{ Awa ngumo } & \multicolumn{2}{|c|}{ Kebon } & \multicolumn{2}{|c|}{$\begin{array}{l}\text { Timber } \\
\text { estate }\end{array}$} \\
\hline & (Ha) & $\%$ & $(\mathrm{Ha})$ & $\%$ & $(\mathrm{Ha})$ & $\%$ & (Ha) & $\%$ & (Ha) & $\%$ \\
\hline $0-10$ & 822 & 12 & 64 & 17 & 22 & 29 & 4 & 40 & 4436 & 90 \\
\hline $10-20$ & 2137 & 31 & 141 & 37 & 33 & 44 & 5 & 50 & 483 & 10 \\
\hline $20-30$ & 1827 & 26 & 95 & 25 & 15 & 20 & 1 & 10 & 18 & 0 \\
\hline $30-40$ & 1234 & 18 & 47 & 12 & 3 & 4 & & 0 & 1 & 0 \\
\hline $40-50$ & 622 & 9 & 19 & 5 & 1 & 1 & & 0 & & 0 \\
\hline $50-60$ & 249 & 4 & 11 & 3 & 1 & 1 & & 0 & & 0 \\
\hline$>60$ & 92 & 1 & 4 & 1 & & 0 & & 0 & & 0 \\
\hline Total & 6983 & 100 & 381 & 100 & 75 & 100 & 10 & 100 & 4938 & 100 \\
\hline
\end{tabular}

Table 4. 6. Distribution of Rantau Layung forest based on slope class.

\begin{tabular}{|c|c|c|c|c|c|c|c|c|c|c|}
\hline \multirow{3}{*}{ Slope $\left(^{\circ}\right)$} & \multicolumn{10}{|c|}{ Land-use } \\
\hline & \multicolumn{2}{|c|}{ Alas ADAT } & \multicolumn{2}{|c|}{$\begin{array}{c}\text { Awa } \\
\text { pangeramu }\end{array}$} & \multicolumn{2}{|c|}{$\begin{array}{c}\text { Alas } \\
\text { Nareng }\end{array}$} & \multicolumn{2}{|c|}{$\begin{array}{c}\text { Awa penyekulo/ } \\
\text { Awa Ngumo }\end{array}$} & \multicolumn{2}{|c|}{ Strat } \\
\hline & (Ha) & $\%$ & (Ha) & $\%$ & (Ha) & $\%$ & $(\mathrm{Ha})$ & $\%$ & $(\mathrm{Ha})$ & $\%$ \\
\hline $0-10$ & 1045 & 13 & 972 & 18 & 702 & 13 & 2171 & 42 & 187 & 80 \\
\hline $10-20$ & 2221 & 27 & 1658 & 32 & 1376 & 25 & 1880 & 37 & 33 & 14 \\
\hline $20-30$ & 2287 & 28 & 1289 & 25 & 1481 & 27 & 778 & 15 & 13 & 6 \\
\hline $30-40$ & 1575 & 19 & 827 & 16 & 1092 & 20 & 246 & 5 & 1 & 0 \\
\hline $40-50$ & 787 & 10 & 326 & 6 & 542 & 10 & 59 & 1 & & 0 \\
\hline $50-60$ & 263 & 3 & 115 & 2 & 178 & 3 & 3 & 0 & & 0 \\
\hline$>60$ & 76 & 1 & 73 & 1 & 57 & 1 & & 0 & & 0 \\
\hline Total & 8254 & 100 & 5260 & 100 & 5428 & 100 & 5137 & 100 & 234 & 100 \\
\hline
\end{tabular}

\subsubsection{ADAT land-use analysis}

Historically, the ADAT communities around MLPF consider the forest as the mother of life, which protects them from hunger and supplies them with everything they need. They combine swidden agriculture and forest products as the basis for their livelihoods. Hunting, gathering, and fishing are their secondary or supplementary food sources and sources of cash income. In Muluy, the revenues earned from non-timber forest products (rattan, honey, birds, wild meat) are their only sources of cash to buy consumer goods (food, clothing, motorcycles, electrical goods, furniture etc.).

For their daily food, Rantau Layung and Muluy people cultivate primarily upland rice in shifting cultivation systems applying very low amounts of 
fertilizer, herbicides and other agro chemical inputs. Traditionally, land parcels were 1 to 3 hectares per family, constant from year to year, which provided insufficient yields per year for their consumption. The minimal use of production inputs has resulted in relatively low agricultural outputs compared to existing standards. Rice production, equal to 107 $\mathrm{kg} / \mathrm{capita} / \mathrm{year}$, is under the optimum standard of living in Indonesia which is equivalent to 1 ton of rice/capita/year (Kementerian Negara Lingkungan Hidup 2014). Only relying on low quality seedlings, minimum fertilizers and limited capacity in pest control, the annual net average production of upland rice, oil palm, and rubber were $0.6,3.6$ and 0.48 tons/ha respectively between 2010 and 2011(Nugroho et al., 2017). This is low compared to the annual district productivity levels of 2.9, 14, and 1.4 tons/ha in the same period (BPS Kabupaten Pasir 2011).

Upland rice was planted for two to three seasons (2-3 years) followed by an average of ten years fallow. After three years, when productivity declined, farmers moved to regenerated secondary forest, their previous fallow sites, and cleared them using slash and burn methods. According to villagers from Muluy and Rantau Layung, the successive phases of regeneration, from swidden fields to primary forest, may take more than thirty years.

Currently, Rantau Layung people live in the area along the Kandilo River where they have good means of transportation and a source of food and water. The name Rantau Layung means 'straight river' (rantau) with many lahung or layung trees (Durio sp.) in the area. Historically, their access to markets was only possible when the rivers were high enough to allow transport by boat. During our research, there was road access by car in the dry season, connecting the village to the main road (logging road).

The current Muluy settlement, settled in 2001, is situated in the middle of MLPF on the roadside of the logging road that passes through MLPF, $6 \mathrm{~km}$ from Swan Slutung Village, the previous settlement of the Muluy people. Originally, the Muluy people were nomadic; they lived separately near their agricultural fields. After 2-3 years, settlements were abandoned as part of the traditional swidden agricultural system. They often moved to a new place to find good agricultural land and forest products (Murniati et al., 2006). In recent history, the pattern of movement has been influenced by family disputes, civil insurgency, transmigration, large-scale logging and road construction (Wahyuni, 2011). In 1993, the regional government moved 22 families to Swan Slutung as part of the transmigration program.

In Rantau Layung and Muluy, apart from State law, ADAT law is applied in daily life as traditional guidelines and rules to define what is right or wrong, what can be done and what is forbidden for the whole community. The 
planting season; the best time to start land clearing, ploughing and planting, in which areas, and how large an area can be utilized per household, and which trees are forbidden to cut, are all guided by ADAT regulations and beliefs. In Muluy as well as Rantau Layung, it is prohibited to cut down honey trees (Koompassia malaccensis/Kempas) and to disturb an area dominated by ironwood trees (Eusideroxylon zwageri/Ulin) (Murniati et al., 2006; Wahyuni, 2011). The ADAT people may only use the forest area in Muluy or Rantau Layung with community permission granted in a community meeting. Based on ADAT rule, to cut and sell timber from the forest is forbidden for inhabitants and outsiders. The ADAT people of both communities believe that any actions against the ADAT law will result in disaster for the transgressor/s who will have to pay a fine to the ADAT council. The outsiders and immigrants are forbidden to open forests for rubber or oil palm plantations unless they buy from the ADAT people or through marriage.

During our research, the villagers of Rantau Layung had already generated a cash income selling products from industrial crops (fresh fruit bunches of oil palm and rubber) and cash crops (durian, candle nut, vegetables). In contrast, the Muluy people still depended on forest products such as fruits, honey, rattan, and wild meat for cash.

We analyzed the spatial distribution of ADAT land use from 1992 to 2012 based on the interpretation of landsat images from six different years. The spatial distribution of ADAT land-use expansion for the period 1992 to 2012, for Muluy and Rantau Layung, is illustrated in Figure 4.5 and 4.6. Tables 4.7 and 4.8 show the extent of the expansion based on location. 


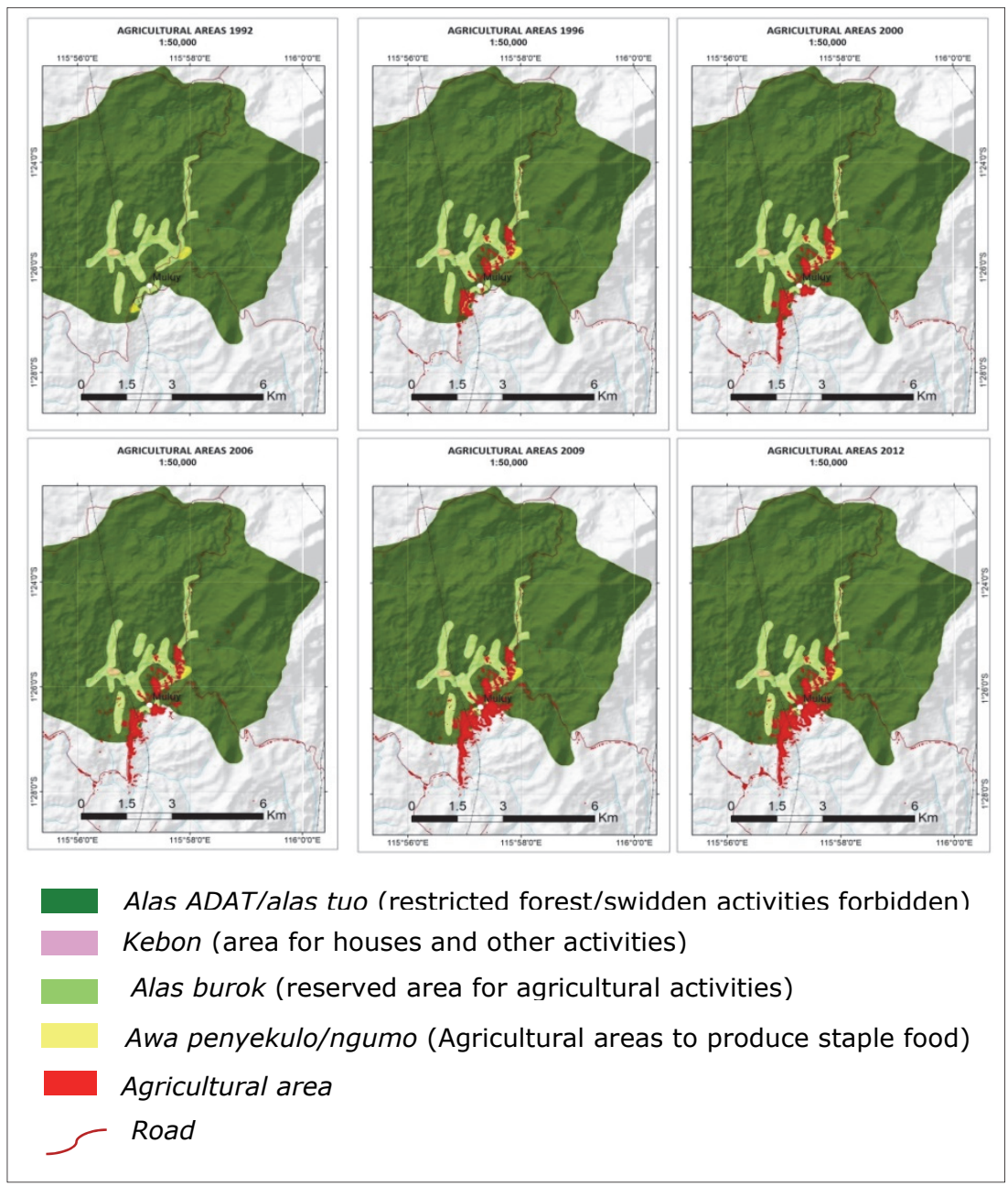

Figure 4. 3. Spatial distribution of changes of ADAT land-use of Muluy for the period 1992 to 2012.

In Tables 4.7 and 4.8 we can see that traditional land-use expansion decreases in all ADAT forest areas but increases outside the customary area. 
Table 4. 7. Trends in ADAT land-use expansion of Muluy from 1992 to 2012.

\begin{tabular}{|c|c|c|c|c|c|c|c|c|c|c|c|c|c|}
\hline \multirow{3}{*}{ Location } & \multicolumn{12}{|c|}{ ADAT land-use expansion } & \multirow{3}{*}{$\begin{array}{l}\text {.0 years } \\
\text { growth } \\
\text { rate } \\
(\%)\end{array}$} \\
\hline & \multicolumn{2}{|c|}{1992} & \multicolumn{2}{|c|}{1996} & \multicolumn{2}{|c|}{2000} & \multicolumn{2}{|l|}{2006} & \multicolumn{2}{|l|}{2009} & \multicolumn{2}{|c|}{2012} & \\
\hline & ha & $\%$ & ha & $\%$ & ha & $\%$ & ha & $\%$ & $\mathrm{Ha}$ & $\%$ & ha & $\%$ & \\
\hline Alas tuo & 2 & 100 & 53 & 45 & 72 & 42 & 81 & 42 & 107 & 41 & 111 & 40 & 5 \\
\hline Alas burok & 0 & 0 & 38 & 32 & 43 & 25 & 45 & 23 & 54 & 21 & 54 & 19 & 2 \\
\hline Awa ngumo & 0 & 0 & 8 & 7 & 10 & 6 & 10 & 5 & 11 & 4 & 11 & 4 & 2 \\
\hline Kebon & 0 & 0 & 0 & 0 & 0 & 0 & 0 & 0 & 0 & 0 & 0 & 0 & 0 \\
\hline $\begin{array}{l}\text { Outside the } \\
\text { territory }\end{array}$ & 0 & 0 & 19 & 16 & 47 & 27 & 57 & 30 & 88 & 34 & 103 & 37 & 12 \\
\hline $\begin{array}{l}\text { Total } \\
\text { Growth rate }\end{array}$ & 2 & 100 & 118 & $\begin{array}{c}100 \\
177\end{array}$ & 172 & $\begin{array}{r}100 \\
10 \\
\end{array}$ & 193 & $\begin{array}{c}100 \\
2 \\
\end{array}$ & 260 & $\begin{array}{c}100 \\
10 \\
\end{array}$ & 279 & $\begin{array}{c}100 \\
2 \\
\end{array}$ & 6 \\
\hline
\end{tabular}

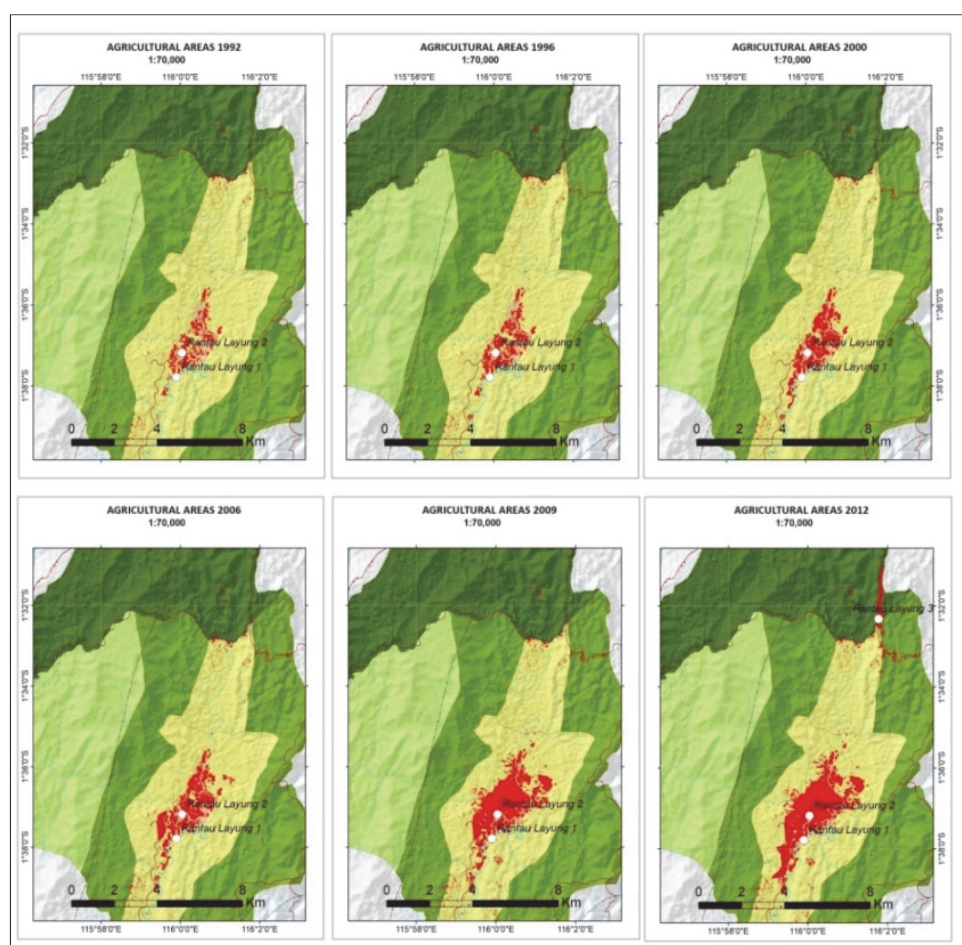

Alas ADAT/alas tuo (restricted forest/swidden activities)

Kebon (area for houses and other activities)

Alas burok (reserved area for aaricultural activities)

Awa penyekulo/ngumo (Agricultural areas to produce

Agricultural

Road

Figure 4. 4. Spatial distribution of changes of ADAT land-use of Rantau Layung for the period 1992 to 2012.

To analyze ADAT land-use expansion in Muluy, we used land-use images from 1996 as a starting image for the analysis. From 1996 to 2012, ADAT land use in Muluy increased from 118 ha to 279 ha at a rate of $6 \%$ per year (Table 
4.7). At the end of 1990s they started to move out of their ADAT forest and opened new land along logging roads. In 2012, 40\% of these 279 ha were in alas tuo, $19 \%$ reopened fallow land (alas burok), and $37 \%$ inside MLPF, outside their territory. Based on land slope, 3.5\% (10 Ha) of their agricultural land was situated in an area with a slope greater than $40 \%$, in which $2.5 \%$ was located in alas ADAT and alas burok and the other $1 \%$ was close to the road outside their territory. Meanwhile, in Rantau Layung, from 1992 to 2012, ADAT land use increased from 248 ha to 930 ha at a rate of $7 \%$ per year (Table 4.8). In general, their agricultural area (67\%) was situated in awa ngumo and awa penyekulo, areas designated for agriculture activities. These areas were cultivated for staple food production such as upland rice, cassava, maize, and for cash crops (candle nut, banana) as well as industrial crops (oil palm and rubber). In 2010, several people from Rantau Layung moved to alas ADAT land close to the logging road but far from their original village to open new land for oil palm. In 2012, almost $90 \%$ of ADAT land use was situated in areas designated for agriculture (awa ngumo, penyekulo, and straat), and less than $8 \%$ was in alas ADAT. However, $3 \%$ was outside their territory. Based on slope gradient, there were 5 ha of agricultural land $(0.5 \%)$ situated in an area with a slope greater than $40 \%$.

Table 4. 8. Trend in ADAT land-use expansion of Rantau Layung from 1992 to 2012.

\begin{tabular}{|c|c|c|c|c|c|c|c|c|c|c|c|c|c|}
\hline \multirow{3}{*}{ Location } & \multicolumn{12}{|c|}{ ADAT land use expansion } & \multirow{3}{*}{$\begin{array}{c}20 \\
\text { years } \\
\text { growth } \\
\text { rate } \\
(\%)\end{array}$} \\
\hline & \multicolumn{2}{|c|}{1992} & \multicolumn{2}{|c|}{1996} & \multicolumn{2}{|c|}{2000} & \multicolumn{2}{|c|}{2006} & \multicolumn{2}{|c|}{2009} & \multicolumn{2}{|c|}{2012} & \\
\hline & ha & $\%$ & ha & $\%$ & ha & $\%$ & ha & $\%$ & ha & $\%$ & ha & $\%$ & \\
\hline Alas ADAT & 10 & 4 & 12 & 4 & 12 & 3 & 12 & 2 & 12 & 2 & 61 & 7 & 10 \\
\hline Awa pangeramu & 3 & 1 & 4 & 1 & 10 & 2 & 13 & 2 & 16 & 2 & 30 & 3 & 13 \\
\hline Awa penyekulo/ & & & & & & & & & & & & & \\
\hline Ngumo & 141 & 57 & 164 & 54 & 224 & 55 & 540 & 75 & 540 & 70 & 622 & 67 & 8 \\
\hline Straat & 83 & 33 & 113 & 37 & 147 & 36 & 148 & 20 & 182 & 24 & 191 & 21 & 4 \\
\hline $\begin{array}{l}\text { Outside the } \\
\text { territory }\end{array}$ & 11 & 4 & 11 & 4 & 11 & 3 & 11 & 2 & 18 & 2 & 26 & 3 & 2 \\
\hline Total & 248 & 100 & 304 & 100 & 404 & 100 & 724 & 100 & 768 & 100 & 930 & 100 & 7 \\
\hline Growth rate & & & & 5 & & 7 & & 10 & & 2 & & 7 & \\
\hline
\end{tabular}

Traditional land use in Muluy and Rantau Layung in 2012 are presented in Figure 4.7 

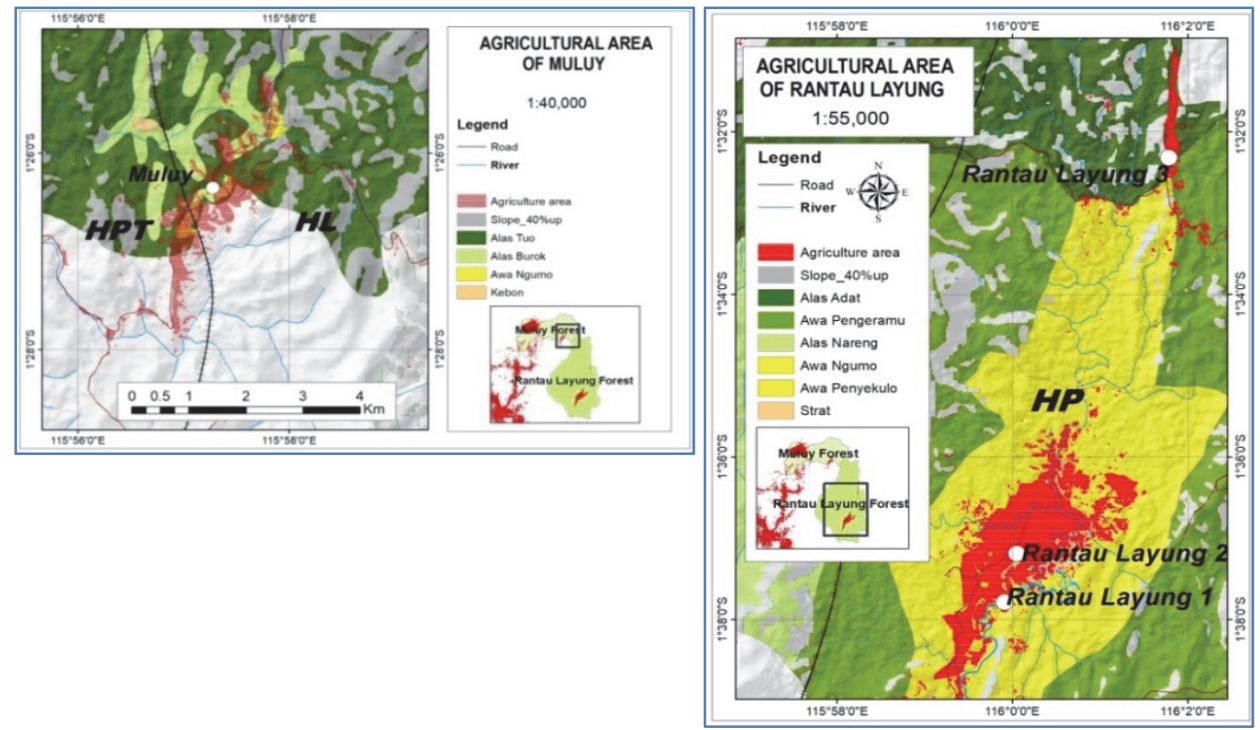

Figure 4. 5. Traditional land-use in Muluy and Rantau Layung 2012.

The major difference between Muluy and Rantau Layung is the extent and level of permanent farming. The people of Muluy have not yet adopted intensified, permanent farming as the people of Rantau Layung have. In Rantau Layung, the farmers, especially the immigrants, have developed productive industrial crops (oil palm and rubber) and cash crops such as vegetables, bananas, and other fruit trees using agriculture inputs. The immigrants extended their agricultural area by buying from other farmers especially the ADAT people. In contrast to the ADAT people, the immigrants had intensified farming systems of planting food crops (e.g., upland rice, soybeans, maize) and industrial crops (rubber and oil palm). However, immigrant and indigenous communities do exchange knowledge of their farming systems. The villagers of Rantau Layung have already generated a cash income by selling produce from their industrial crops (fresh fruit bunch of oil palm and rubber) and cash crops (durian, candle nut, vegetables). However, the Muluy people still depend on forest products such as fruits, honey, rattan, and wild meat for generating a cash income.

Based on the results of the spatial analysis, as presented in Table 4.5, 4.6, 4.7, and 4.8, including areas (alas ADAT/tuo forest areas outside their territory) that should not have been cultivated, we have calculated when the existing agricultural areas of Muluy and Rantau Layung will be exhausted (Table 4.9). 
Table 4. 9. Predicted time remaining

\begin{tabular}{|c|c|c|c|c|c|c|c|}
\hline \multirow{2}{*}{ Land Allocation } & \multicolumn{4}{|c|}{ Agricutural Area $(\mathrm{Ha})$} & \multicolumn{2}{|c|}{$\begin{array}{l}\text { Existed ADAT } \\
\text { land-use }\end{array}$} & \multirow{2}{*}{$\begin{array}{c}\text { Remaining } \\
\text { time*) } \\
\text { (years) }\end{array}$} \\
\hline & Total & $<40 \%$ & $\begin{array}{c}\text { Utilized } \\
\text { area }\end{array}$ & $\begin{array}{c}\text { Unutilized } \\
\text { area }\end{array}$ & $\begin{array}{l}\text { Area } \\
(\mathrm{Ha})\end{array}$ & $\begin{array}{l}\text { Growth } \\
\text { rate }(\%)\end{array}$ & \\
\hline & & & & $(\mathrm{Pt})$ & (Po) & $(r)$ & $(\mathrm{t})$ \\
\hline Muluy & & & & & & & \\
\hline Alas burok & 381 & 347 & 54 & 293 & & & \\
\hline Awa ngumo & 75 & 73 & 11 & 62 & & & \\
\hline Total & 456 & 420 & 65 & 355 & 279 & 6 & 5 \\
\hline Rantau Layung & & & & & & & \\
\hline $\begin{array}{l}\text { Alas nareng } \\
\text { Awa }\end{array}$ & 5,428 & 4,651 & 0 & 4,651 & & & \\
\hline Penyekulo/Ngumo & 5,137 & 5,075 & 622 & 4,453 & & & \\
\hline Total & 10,565 & 9,726 & 622 & 9,104 & 930 & 7 & 35 \\
\hline
\end{tabular}

\subsection{Discussion}

Traditional knowledge, distinct culture and beliefs, value systems and law, myths, strong links to territories and surrounding natural resources are considered to be the true characteristics of indigenous people (Juanwen et al., 2012; Kawharu, 2011; Kementerian PPN/BAPPENAS 2013). The question is, are all those 'distinct characteristics' reflected in their attitude and behavior.

The ancestors of the Muluy and Rantau Layung communities determined a function-based land distribution long ago. However, the boundaries were not written down. In the early 2000s the ADAT people, with local NGO assistance, produced maps of the area. From interpretations of the ADAT maps (Figure 4.3), supported by a series of field visits, we concluded that in general the ADAT people have traditional knowledge to manage their forests.

Overlaying the ADAT forest maps and forest designation maps, we can see that the function-based land distribution of the ADAT territories of both communities are in line with the criteria for land determination of the Ministry of Environment and Forestry. In Rantau Layung the awa ngumo, awa penyekulo, and awa pengeramu areas of the village are situated in production forest. Alas ADAT and alas nareng areas are situated in protection forests and production forests. The Muluy community moved to what is now the core of MLPF, around 1900, long before the area was designated production forest (in 1983), awa penyekulo, kebon and alas burok, which are mostly located on gentle slopes, are now situated in protection forest. Based on our analysis of the potential risks of degradation associated with land use, we found that ADAT forest designation maps, in both communities, correspond to the government regulations concerning forestry and spatial planning (Republik Indonesia 1999, 2008). In both, the land area with a slope greater than $40 \%$ is designated as protection areas. 
The ADAT people have accepted and worked with their traditional knowledge for many generations. However, there are global concerns that due to consumerism and short-term economic considerations, wisdom, norms and values of the ADAT communities may be slowly eroding (Huntington et al., 2004; Kothari, 2007; Samho \& Purwadi, 2016). From ADAT land-use expansion patterns from 1992 to 2012, we found that the need for cash has changed the behavior of villagers towards nature, including that of the ADAT people. Following road construction and a boom in industrial tree production (rubber and oil palm) in the early 2000s, there was a change in the social conditions of the community around MLPF (Murniati et al., 2006; Nugroho et al., 2017; Wahyuni, 2011). Farmers in Rantau Layung as well as Muluy started to cultivate industrial crops. Many farmers have started to cultivate rubber or oil palm crops intercropped with upland rice. After 3 years, when the rubber/oil palm canopies block the sun and the rice cannot grow, they start to clear new land for another plantation of mixed crops. They will not be able to return to the land after 15 years, as they would with fallow, due to the presence of the rubber and oil palm. Thus each household must cut and clear either primary or secondary forest, including that inside MLPF every two to three years. This situation is in line with the findings of several scholars. The increase in population and culture diversity in the region, better accessibility and contact with external people with different values and attitudes has increased the need for cash and so the indigenous people's behavior towards nature has changed (Kothari, 2007; Luz et al., 2015; Muur, 2015).

The expansion of the agricultural area in Muluy and Rantau Layung (Figure 4.7) follows a similar pattern of opening new land close to the main road for better transportation and access to markets. The majority $(80 \%)$ of ADAT land-use expansion was located on slopes of less than $10 \%, 17 \%$ on slopes of $10-25 \%$ and only $3 \%$ on slopes greater than $25 \%$. Our previous research confirmed the belief that the presence of a road contributes to the rapid expansion of agricultural activities (Nugroho et al., 2017). Up to 2012, of the 279 ha of Muluy's agricultural land, 103 hectares (37\%) were situated on both sides of the road, outside the ADAT forest area, with an average growth rate of $12 \%$ per year. In general, the ADAT land-use expansion of Muluy started from the village and the periphery of agricultural areas expanding parcel by parcel along the roadside. Based on our interviews, their main concerns in deciding which particular locations to cultivate were distance from the village, slope and accessibility. With respect to distance to the main road, $87 \%$ of new traditional land use around MLPF was located less than $1 \mathrm{~km}$, and $12 \%$ between 1 to $2 \mathrm{~km}$ (Nugroho et al., 2017) .

It is understandable that the Muluy people wanted to expand their ADAT land use into areas outside their territory. The 'encroached' areas were closer to 
the village and more accessible compared to alas burok, (reserved areas for agriculture). From Table 4.5, we can see that areas suitable for agricultural activities (areas with a slope less than $40 \%$ ) in Muluy were 73 ha $(1 \%)$ of awa ngumo (agricultural area) and 420 ha $(5.6 \%)$ of alas burok (reserved areas for agriculture). If divided by the number of Muluy people (128), the suitable area is only $3.3 \mathrm{ha} / \mathrm{capita}$. Using the existing average growth rate of ADAT land-use expansion of $6 \%$ (Table 4.7 ), land suitable for agriculture will be exhausted within the next 5 years (Table 4.9). As a result, instead of moving to their existing agricultural land inside their ADAT territory, Muluy people prefer to move out to new land along the logging road.

In Rantau Layung, areas suitable for agricultural activities were 5,075 ha (21\%) of awa penyekulo/awa ngumo (agricultural area) and 4,651 ha (19\%) of alas nareng (reserved areas for agriculture). If divided by the number of Rantau Layung people (226), the suitable area is 43 ha/capita. Using the existing average growth rate of $7 \%$ (Table 4.8), land suitable for agriculture will be exhausted within the next 35 years (Table 4.9). In 2008, several people from Rantau layung moved to alas ADAT close to the logging road and far from the original village, to open up 40 ha of new land for oil palm. While opening the new land they built temporary houses, which, as the number of settlers increased, became a permanent settlement.

The land suitable for agricultural activities in Rantau Layung is still large and sufficient to meet the needs of future generations. However, allocated land for agriculture in Muluy is very limited. To reduce the potential pressure on adjacent forest areas, it is necessary to restructure the management and use of the ADAT forest of Muluy through a compensation mechanism regulated by the Ministry of Environment and Forestry. The regulation (Ministry of Environment and Forestry Regulation P.32/Menlhk-Setjen/2015 on Titled Forest) concerned with this area of forestry, states that:

"Forested land may be designated as titled forest with a specific function based on ecosystem considerations from the Ministry of Environment and Forestry and the approval of titled holders. If the ADAT people object to this provision, the minister shall provide compensation and/or incentives in accordance with the regulation" (article 7, point 1 and 2).

Any special measures must deal with the complex processes of the recognition and implementation of ADAT rights together with government concerns for the sustainable management of the forest, business offers from investors, and the ADAT people's efforts to secure their livelihoods and to exercise territorial sovereignty. Long-term engagement with the ADAT people must be planned and implemented systematically to assist ADAT forest management in providing sustainable benefits from the forest for all, for 
many generations to come. Formal law enforcement and revitalization of ADAT law is an essential measure to be conducted in-line with efforts to enhance community welfare. Otherwise, the next ADAT generation will note that their forest was lost because of their ancestors' poor governance.

\subsection{Conclusion}

This paper explores one narrow, but important aspect of the complex processes in ADAT rights recognition that has not only affected the practical implications, but also presents a challenge for the long-term success of the transfer of rights to forest and the sustainable use of ADAT forest.

This case study illustrates that the ADAT people living around MLPF own and apply their ancestral norms, beliefs and traditional wisdom and knowledge. Nonetheless, the increasing desires for a modern life, better accessibility and socio-cultural assimilation have changed the ADAT people's behavior towards nature. Notwithstanding the social importance of customary land rights, the two cases used in this paper indicate that the critique of environmentalists regarding ADAT people might be justified. We are pessimistic that a 'selfsustaining community with strong connections with nature' discourse, as an identity of ADAT community, can be upheld for much longer. Even remote people are forced by the 'necessities of life' to convert ancestral forest into rubber and oil palm plantations to simply survive.

Relying on a legal approach based on judicial and physical data alone to prove the indigeneity of ADAT people is not enough. Adequate and wellcontrolled investigation must be employed to examine the capacity, capabilities and awareness of indigenous peoples to manage their territory sustainably. The transfer of control rights to forest was not merely a form of transfer of ownership or political approach, but also an attempt to ensure that the ADAT forest remains and is sustainably managed for the benefit of the ADAT community and the environment. Holistic approaches in transferring land rights, effective long-term engagement, and revitalization of ADAT law in line with formal law enforcement, are among the essential measures that must be conducted systematically. Otherwise, the Indonesian ADAT forest will not survive.

Finally, the accuracy of the spatial analysis may be subject to question. Different resolutions of spatial data may produce different results. However, by combining spatial analysis, field surveys, and socio-cultural analysis to assess the traditional knowledge and ADAT law implementations, as rational as possible, we provide an overview of substantial evidence of the indigeneity as a basis for the transfer of rights to forest. 


\subsection{Acknowledgement}

This work was prepared based upon a collaborative research project between the Forestry Research and Development Agency, Tropenbos International Indonesia Program, the Faculty of ITC University of Twente and Mulawarman University in East Kalimantan, 2008-2012, entitled "Integrating Customary Rights and Traditional Land Use into Spatial Planning: The Use of Appropriate Modelling for Decision Support Systems". No. PIS. 50100020. We thank the people of Muluy and Rantau Layung for their support during our fieldwork. The authors would like to thank Glen Mulcahy for the revision of the article from a linguistic point of view.

\section{References}

Arizona, Y. and E. Cahyadi, The Revival of Indigenous Peoples: Contestations over a Special Legislation on Masyarakat Adat, in Adat and Indigeneity in Indonesia Culture and Entitlements between Heteronomy and Self-Ascription, B. Hauser-Schäublin, Editor. 2013, Göttingen University Press: Göttingen. p. 43-62.

Astuti, R. and A. McGregor, Indigenous land claims or green grabs? Inclusions and exclusions within forest carbon politics in Indonesia. The Journal of Peasant Studies, 2016: p. 1-22.

Bakker, L. "Can We Get Hak Ulayat?": Land and Community in Pasir and Nunukan, East Kalimantan. in UC Berkeley-UCLA Joint Conference on Southeast Asia, "Ten Years After: Reformasi and New Social Movements in Indonesia, 1998-2008". 2008. The University of California Berkeley, California: Centre for Southeast Asia Studies UC Berkely.

Boedhihartono, A.K., Can Community Forests Be Compatible With Biodiversity Conservation in Indonesia? Land 2017. 6, 21: p. 17.

BPS Kabupaten Pasir Kabupaten Pasir Dalam Angka 2011. 2011, Tanah Grogot: Badan Pusat Statistik Kabupaten Pasir.

Cahyadi, F. Pidato Sekretaris Jenderal (Sekjen) AMAN \#HKMAN2014. 2014 [cited 201716 September 2017]; 18/03/2014:[Available from: http://www.aman.or.id/pidato-sekretaris-jenderal-sekjen-amanhkman2014/.

Coutant, D., D. Riggs, and E. Van Sant Hoffman, Substantial Evidence: When is a Single Trial Sufficient for Approval and Promotion? Drug Information Journal, 2011. 45(3): p. 253-263.

Gauset, Q., J. Kenrick, and R. Gibb, Indigeneity and autochthony: a couple of false twins? Social Anthropology/Anthropologie Sociale, 2011. 19 (2): p. 135-142.

Grydehøj, A. and Z. Ou, Deterritorialization of indigeneity: Indigenous territory, development policy, and the Dan fishing community of 
Hainan (China). Political Geography, 2017. 61(Supplement C): p. 7787.

Guidotti, T.L., Traditional Knowledge: Challenge or Complement to Science? Archives of Environmental \& Occupational Health, 2007. 62(4): p. 167-168.

Huntington, $\mathrm{H}_{\text {., }}$ et al., Matching traditional and scientific observations to detect environmental change : A discussion on Arctic terrestrial ecosystems. Ambio, 2004(13): p. 18-23.

Juanwen, Y., W. Quanxin, and L. Jinlong, Understanding indigenous knowledge in sustainable management of natural resources in China: Taking two villages from Guizhou Province as a case. Forest Policy and Economics, 2012. 22(0): p. 47-52.

KATR/BPN, Tata Cara Penentuan Hak Komunal atas Tanah Masyarakat Hukum Adat dan Masyarakat yang Berada dalam Kawasan Tertentu. 2015: Peraturan Menteri Agraria dan Tata Ruang/Kepala Badan Pertanahan Nasional, Nomor 9 Tahun 2015.

KATR/BPN, Tata Cara Penetapan Hak Komunal atas Tanah Masyarakat Hukum Adat dan Masyarakat yang Berada pada Kawasan Tertentu, ed. K.A.d.T.R.K.B.P. Nasional. 2016: Peraturan Menteri Agraria dan Tata Ruang/Kepala Badan Pertanahan Nasional Nomor 10 Tahun 2016.

Kawharu, M., Forestry and indigenous issues: New Zealand and the Pacific, in International Expert Group Meeting Indigenous Peoples and Forests. 2011, Department Of Economic And Social Affairs, The Nations Unies, The United Nation: New York.

KEMENDAGRI Pedoman Pengakuan dan Perlindungan Masyarakat Hukum Adat. Berita Negara Republik Indonesia Tahun 2014 Nomor 951, ed. R.I. Menteri Hukum Dan Hak Asasi Manusia. 2014: Peraturan Menteri Dalam Negeri Nomor 52 tahun 2014.

KEMENDAGRI, K., PU,BPN , i, Tata Cara Penyelesaian Penguasaan Tanah yang Berada di Dalam Kawasan Hutan. Berita Negara Republik Indonesia Tahun 2014 Nomor 1.719, ed. R.I. Menteri Hukum Dan Hak Asasi Manusia. 2014: Peraturan Bersama Nomor : 79 Tahun 2014, PB.3/Menhut-11/2014, 17/PRT/M/2014, 8/SKB/X/2014.

Kementerian Negara Lingkungan Hidup Pedoman Penentuan Daya Dukung dan Daya Tampung Lingkungan Hidup. 2014, Jakarta: Kementerian Negara Lingkungan Hidup Republik Indonesia.

Kementerian PPN/BAPPENAS Masyarakat Adat di Indonesia: Menuju Perlindungan Sosial yang Inklusif. 2013, Jakarta: Direktorat Perlindungan dan Kesejahteraan Masyarakat, Kementeriaan PPN/Bappenas.

KLHK, Hutan Hak. Berita Negara Republik Indonesia Tahun 2015 Nomor 1025, ed. R.I. Menteri Hukum Dan Hak Asasi Manusia. 2015: Peraturan Menteri Lingkungan Hidup dan Kehutanan Nomor P.32/Menlhk-Setjen/2015. 
KLHK, Penanganan Konflik Tenurial Kawasan Hutan. Berita Negara Republik Indonesia Tahun 2016 Nomor 165, ed. R.I. Menteri Hukum Dan Hak Asasi Manusia. 2015: Menteri Lingkungan Hidup dan Kehutanan Nomor P.84/Menlhk-Setjen/2015.

Kothari, A., Traditional Knowledge and Sustainable Development. 2007, International Institute for Sustainable Development (IISD): Manitoba, Canada.

Kuper, A., The Return of the Native. Current Anthropology, 2003. 44 (3): p. 389-402.

Li, T., xa, and Murray, Indigeneity, Capitalism, and the Management of Dispossession. Current Anthropology, 2010. 51(3): p. 385-414.

Linggasari, Y. Pengabaian Hak Masyarakat Adat Bisa Berujung Separatisme. 2016 [cited 201716 August ]; 24 Januar 2016y:[Available from: https://www.cnnindonesia.com/nasional/20160124195910-20106337/pengabaian-hak-masyarakat-adat-bisa-berujungseparatisme/.

Luz, A., et al., How Does Cultural Change Affect Indigenous Peoples' Hunting Activity? An Empirical Study Among the Tsimane' in the Bolivian Amazon. Conservation and Society, 2015. 13(4): p. 382-394.

Mahkamah Konstitusi Republik Indonesia Pengujian Undang Undang 41 tahun 1999 tentang Kehutanan 20 Mei 2013 ed. 2013: Putusan Mahkamah Konstutisi Republik Indonesia Nomor 35/PUU-X/2012.

Martinez, D., The Value of Indigenous Ways of Knowing to Western Science and Environmental Sustainability. The Journal of Sustainability Education, 2010.

Mazzocchi, F., Western science and traditional knowledge: Despite their variations, different forms of knowledge can learn from each other. EMBO Reports, 2006. 7(5): p. 463-466.

Mulyoutami, E., R. Rismawan, and L. Joshi, Local knowledge and management of simpukng (forest gardens) among the Dayak people in East Kalimantan, Indonesia. Forest Ecology and Management, 2009. 257(10): p. 2054-2061.

Murniati, et al., Gunung Lumut biodiversity assessment socio-economic study: how important forest and landscape resource for community living in and around Gunung Lumut protection forest? Final report to TROPENBOS. 2006, Bogor, Indonesia: Center for International Forestry Research (CIFOR).

Muur, W.v.d. Will customary land rights destroy Indonesia's last remaining forests? 2015 [cited 201525 April 2015]; Available from: http://leidenlawblog.nl/articles/will-customary-land-rights-destroyindonesias-last-remaining-forests.

Myers, R., et al., Claiming the forest: Inclusion and exclusion under Indonesia's "new" policy on cutomary forest. Land Use Policy, 2017. 66: p. 205-213. 
Nair, M.S., Defining Indigeneity Situating Transnational Knowledge. 2006: New Delhi.

Nugroho, H.Y.S.H., et al., Expansion of traditional land-use and deforestation: a case study of an adat forest in the Kandilo Subwatershed, East Kalimantan, Indonesia. Journal of Forestry Research, 2017.

PSKL, Tata Cara Verifikasi dan Validasi Hutan Adat. 2016, Jakarta: Direkorat Jenderal Perhutanan Sosial dan Kemitraan Lingkungan

Republik Indonesia Kehutanan. Lembaran Negara Republik Indonesia Tahun 1999 Nomor 167, ed. M.N.S.N.R. Indonesia. 1999: Undang Undang Nomor 41 Tahun 1999

Republik Indonesia Rencana Tata Ruang Nasional. Lembaran Negara Republik Indonesia Tahun 2008 nomor 48 ed. Kementerian Hukum dan Hak Asasi Manusia 2008, Jakarta: Peraturan Pemerintah Nomor 26 Tahun 2008

Royer, S.D., et al., Self-identification of indigenous people in postindependence Indonesia: a historical analysis in the context of REDD+. International Forestry Review 2015. Vol.17(3).

Samho, B. and Y.S. Purwadi, Perubahan Pola Pikir Masyarakat Adat Dayak di Kabupaten Sanggau terhadap Hutan Adat Sebagai Akibat Perkebunan Kelapa Sawit. 2016, Lembaga Penelitian dan Pengabdian kepada Masyarakat, Universitas Parahyangan: Bandung.

Sasaoka, M. and Y. Laumonier, Suitability of Local Resource Management Practices Based on Supernatural Enforcement Mechanisms in the Local Social-cultural Context. Ecology and Society, 2012. 17(4).

Siscawati, M., et al., Overview of forest tenure reforms in Indonesia. 2017, Centre for International Forestry Research (CIFOR): Bogor, Indonesia. p. 36.

Snively, G. and J. Corsiglia, Discovering indigenous science: Implications for science education. Science Education, 2001. 85(1): p. 6-34.

Stason, E.B., "Substantial Evidence" in Administrative Law. University of Pennsylvania Law Review and American Law Register, 1941. 89(8): p. 1026-1051.

Tropenbos International Indonesia Penilaian Ekonomi Sumberdaya Hutan Lindung Gunung Lumut, Kabupaten Paser, Kalimantan Timur. 2006, Tropenbos International Indonesia dan Greenomics Indonesia: Bogor, Indonesia.

UNHR, Indigenous Peoples and the United Nations Human Rights System. 2013, United Nations Human Rights, Office of The High Commisioner: New York and Geneva.

Wachira, G.M., Applying Indigenous Peoples' Customary Law in Order to Protect their Land Rights in Africa, in Development and Customary Law, G. Rose and J. Dahl, Editors. 2010, International Work Group for Indigenous Affairs: Copenhagen, Denmark. p. 6-15. 
Wahyuni, T., Can traditional forest management protect and conserve ironwood (ulin) stands? An option and approach in East Kalimantan, in the Institute of Environmental Sciences and Faculty of Social and Behavioural Sciences. 2011, University of Leiden: Leiden, The Netherlands. 


\section{CHAPTER 5}

\section{ENGAGING WITH INDIGENOUS PEOPLES IN SUSTAINABLE FOREST MANAGEMENT ${ }^{4}$}

\footnotetext{
4 This chapter is based on:
}

Nugroho, H. Y. S. H., Skidmore, A. K., \& Hussin, Y. A. (2019). Engaging with ADAT peoples in Sustainable Forest Management. Paper under review in Development and Change 


\begin{abstract}
In order to provide legal access for indigenous peoples to manage forests, the Indonesian government, in 2013, separated ADAT forests from state forests and granted the ADAT communities ownership rights to their traditional forests. This was a radical step for the government in its effort to engage the ADAT peoples with forest management. The government, civil society and ADAT communities agreed that these rights to forest resources would promote equitable and sustainable forest governance and management reforms. They also agreed that a partial or formal approach would not foster long-term commitment and trust between the government and ADAT communities involved nor would it aid effective dialogue between the parties. Before granting ADAT communities rights to forests, instead of merely admissible evidence, there must be substantial evidence, obtained through well, controlled investigation, as to the ownership of the forest in question. Rights granted to indigenous communities who have no right to the forest or those who do have the right but have no interest or capacity to manage the forest, may result in long-term conflicts in the surrounding area. Based on our studies, there are three important areas that must be addressed: 1) thorough and detailed verification of two aspects of the representativeness of the indigenous people: legitimizing their status and their capacity to manage the forest; 2) anticipation of potential conflict due to excessive and strict use of indigenous people terms and the unilateral claim to territory; and 3) building capacity and trust and promoting dialogue.
\end{abstract}

Keywords: Engagement; legitimation; potential conflict

\title{
5.1 Introduction
}

There has been significant progress in implementing Sustainable Forest Management (SFM), however, many challenges remain (CPF, 2012), especially connected to ownership issues, territory and the basic rights of indigenous communities. Scholars believe that for forest management we must consider the needs and aspirations of the people whose livelihoods depend on forest resources (Defries et al., 2007; Rives et al., 2013). At an international workshop on Deforestation and the Rights of Forest Peoples held in Palangkaraya, Indonesia, in March 2014, delegates agreed that forest destruction could not end without securing forest people's land and territorial rights. More than 60 representatives of indigenous and other forest communities, environmental, human rights and social non-governmental organizations from Africa, Asia and Latin America, attended the workshop. They identified measures that must be taken at all levels to ensure full participation of indigenous people, as key stakeholders in decision-making, 
who inhabit, use, have customary rights to and rely on forests for their identity and survival (FPP et al., 2014).

In Indonesia, a country with more than 1,300 ethnic groups and more than 2,500 languages (BPS, 2010), issues related to indigenous peoples and customary rights have been the topic of conversation and research for many years and have increased considerably since the era of regional autonomy (Banjade et al., 2016; Royer et al., 2015). These issues have become more prominent after the Indonesian Constitutional Court, in May 2013, issued Rule 35/2012 (MK 35), which restored the rights of ADAT (indigenous) peoples to own and manage their territories by annulling the state's ownership of ADAT forest. The granting of these rights was a radical step to engage with ADAT peoples in Indonesian forest management. The Government, civil society and ADAT communities recognize the ADAT people's rights to forest as a basic prerequisite to promote equitable and sustainable forest governance and management reforms.

According to AMAN (Aliansi Masyarakat ADAT Nusantara/Indigenous People's Alliance of the Archipelago), of the 84 million ha of ADAT community territories, in Indonesia, 90 percent are forest (Zakaria, 2017). This has, without special measures, the potential to lead to claims being contested, conflict among stakeholders and forest destruction. Thus, practical solutions to engage with ADAT people are essential if sustainable forest management is to be achieved. Engagement in forest governance suggests interactions between a government and local communities. (Holmes, 2011). Engaging with ADAT people can build trust and a working relationship between them and the government. Closing the Gap Clearinghouse (Council of Australian Governments-COAG) initiative, identified effective engagement requirements that include more than trust and integrity such as working together towards shared goals (Hunt, 2013). It is essential to engage people who are legitimate. Engaging with people who are not legitimate ADAT or are but have little interest or capacity to manage forests may well result in not achieving SFM goals and lead to long-term conflicts in the future.

This paper aims to explore the determinant factors and challenges in engaging with ADAT peoples to obtain sustainable forest as well as the welfare and sovereignty of ADAT people. In this paper, we emphasize 2 determinant factors in the engagement process: (1) confirmation of the legitimate status of the ADAT people concerned, and (2) the financial and technical capacity of these people. We develop the paper based on series of literature studies combined with field research and findings from our research in Paser District, East Kalimantan, Indonesia between 2010 and 2015. The literature studies consisting of series of activities from finding, reviewing and evaluating relevant material, and synthesizing information, are focused on 
exploring the history of indigenous people, their revival, and their relationship with government policies.

The paper is structured in the following way: section one introduces the general concept of the paper; the second provides an overview of the revival of ADAT people; the third explores the two determinant factors of ADAT recognition; the fourth explores the components of good engagement; and the fifth looks at the potential constraints and challenges, while the last section provides concluding remarks.

\subsection{The revival of ADAT People : Struggling for recognition}

\subsubsection{The terms of ADAT}

The concept of indigenous people refers to people who have historically been present continuously in an area, often for thousands of years. (UN, 2009) However, In Indonesia, distinguishing 'indigenous' from 'non-indigenous' groups is complicated (Henley et al., 2007; Tsing, 2002). During Suharto's New Order regime, the official discourse was that all native Indonesians (pribumi) were in a sense indigenous so there were no 'indigenous people' as such (Royer et al., 2015; Tsing, 2002). Yet activists and community leaders fighting for the rights of marginal rural communities have increasingly used the term 'indigenous' to 'grab' attention (Tsing, 2002). The support and inspiration of the international indigenous movements are an important part of the background to the ADAT revival (Henley et al., 2007).

The Indonesian term ADAT means 'custom' or 'tradition' (Henley et al., 2007). It is used to describe complex customary systems, including rights to land and resources, a wide range of traditional rules, social rule, customs, conventions, principles, moral concept and beliefs (Affandi, 2016; Royer et al., 2015; Rye et al., 2017; Tyson, 2010). The term ADAT carries connotations of serene order and consensus (Henley et al., 2007). Yet, interpretation of ADAT may vary within villages and between ethnic groups according to a wide variety of ADAT laws regulating access to land and resources (Royer et al., 2015; Tyson, 2010).

The indigenous activists chose masyarakat ADAT (ADAT community) as the phrase to be used for indigenous people (AMAN, 2012; Henley et al., 2007; Royer et al., 2015; Tsing, 2002). The Indigenous Peoples Alliance of the Archipelago (AMAN) defines masyarakat ADAT as a group of people from the same ancestral lineage who inhabit a certain geographical area and have a distinctive set of ideological, economic, political, cultural and social systems 
and values, as well as a territory (AMAN, 2012). The term is purposely different from the colonial term masyarakat hukum ADAT (ADAT law-abiding community), literal translation of ADAT Rechtsgemenschaapen, which carries the risk of suggesting that the indigenous peoples will only be those who adhere to measurable ADAT law practices (Arizona et al., 2013; Royer et al., 2015). The Basic Agrarian Law (BAL 5/1960), Indonesia's first legal law used the phrase masyarakat hukum ADAT and imposed a number of restrictions in recognizing the land rights of ADAT communities under the term hak ulayat (customary rights): (1) as long as such communities still exist, (2) it may not conflict with the national interests and the State's interests, and (3) shall not contradict the laws and regulations of higher levels (Republik Indonesia 1960). These types of restrictions eventually led to the disappearance of the indigenous people's land rights (Arizona et al., 2013)..

All recent legal regulations regarding the recognition of ADAT rights and ADAT forest validation procedures such as: verification and validation of customary forests (PSKL, 2016), the establishment of communal rights to land of a legally identified customary community and communities within a certain area (KATR/BPN, 2016), settling land tenure within the forest area (KEMENDAGRI, 2014), titled forest (KLHK, 2015a) and the handling of forest tenure conflicts (KLHK, 2015b), use the term masyarakat hukum ADAT to define the indigenous people as the main object of such regulations. The Ministry of Environment and Forestry defines masyarakat hukum ADAT as a group of people who have been living in a certain geographical area for generations, in the territory of the Republic of Indonesia, with ancestral connections and a special relationship with the environment, and who own a value system that governs economics, politics, society, and a legal institution (KLHK, 2015a).

\subsubsection{The revival}

During the New Order regime (1966-1998), the ADAT peoples were alienated from their land, often without proper compensation, in the name of infrastructure development, as well as for mining and timber concessions (Arizona et al., 2013). Many of the areas inhabited by indigenous peoples have been targets of the state's transmigration program, designed to relieve population pressure in poor parts of Java and Bali, which further marginalized the indigenous people (Henley et al., 2007; McKinnon, 2012; UNPO, 2014).

The turning point in the Indonesian political system, from a highly centralized government to a new era of decentralization, came in 1998 (popularly known as the reformation era), at the time of the resignation of President Suharto, the leader of the New Order regime. The reformation era has provided opportunities for local political elites throughout the country to build their 
own local power bases, the 'ADAT' has been one channel through which they have done so(Moeliono et al., 2006). This moment in Indonesian history presented an opportunity for rearranging the relationships between the state and the indigenous communities (Arizona et al., 2013). Communities and ethnic groups across Indonesia have vocally, and sometimes violently, demanded the right to implement elements of ADAT or hukum ADAT (customary law) in their home territories (Easterly, 2000). Regrettably, impatient with the slow process of the legal reform arrangements, many ADAT people pushed their rights by simply occupying state-controlled forest land(Moeliono et al., 2006). Indigenous rights discourses are becoming an important component of rhetorical debates and practical policies (Astuti et al., 2016). Using historical claims, several groups claimed their rights to land encompassing several smaller territories, sometimes even overlapping each other(Moeliono et al., 2006) without the necessary institutional capacity to resolve these problems at the appropriate levels of government (Barr et al., 2001).

The milestone in the history of indigenous people's movement in Indonesia was the establishment of AMAN (Aliansi Masyarakat ADAT Nusantara) in 1999 , one year after the end of the highly centralized government. "If the state does not recognize us, we will not recognize the state", challenged AMAN at its first general congress in 1999 (Arizona et al., 2013; Henley et al., 2007; Tsing, 2002).

The most significant results for the indigenous people's movement in fighting for the rights to land/territory were the issuance of Forestry Law 41/1999, replacing the previous Forestry Law 5/1967 (Basic Forestry Law), and the Decree of the People's Consultative Assembly (Ketetapan MPR, TAP MPR) 9/2001, concerning agrarian reforms and natural resources management, which gave explicit recognition to ADAT rights. Compared to Basic Forestry Law 5/1967, which, in clear legal terms, regulates the rights of legal ADAT communities to forest. The new forestry law (Law 41/1999) recognizes ADAT rights to forest in its use of the term hutan ADAT (ADAT forest) in the body of the law. At the same time, the initiatives of regulatory legislations, such as laws pertaining to local governance, water resources, forestry, and the management of coastal areas and small Islands, indicate that there is a legislative trend towards acknowledging the existence and rights of indigenous peoples (Arizona et al., 2013). However, despite the fact that many laws were introduced, these laws do not solve the existing problems (Kementerian PPN/BAPPENAS 2013). On the contrary, they make the situation even more complex, and are rarely implemented. ADAT people are still alienated from their territory (Linggasari, 2016). Forestry Law 41/1999 stipulates that ADAT forest is part of state forest. The law states that, "ADAT forests are state forests located in the areas of legal ADAT communities". 
Under the Ministry of Forestry policy, communities and ADAT communities are only allowed to manage and use their rights to forest within a fixed framework of the Ministry(Moeliono et al., 2006). The law regulates that ADAT forest shall be determined as long as it exists in reality and its existence is recognised by the state. In many cases, ADAT people who have lived in (state) forest for generations, before the issuance of Forestry Law 41/1999 have been accused of encroaching (Arizona et al., 2013; H. Hartanto et al., 2008; Wijaya, 2014). In many parts of Indonesia, ADAT communities have been blamed for deforestation and forest destruction (Cahyadi, 2014a; Wijaya, 2014). These accusations have led to conflict in almost every Indonesian region (IWGIA, 2011; Wijaya, 2014). Based on their observations of the national mass media, articles from January 1997 to June 2003, Wulan et al., described the frequency of forest-related conflicts in Indonesia as having increased dramatically in the early implementation of decentralization, implemented in 2000 (Wulan et al., 2004).

An important step forward for the ADAT people's movement began on 16 May 2013, when the Indonesian Constitutional Court through Regulation 35/PUUX/2012, on the Judicial Review of Law 41/1999, on Forestry (MK 35), delivered by indigenous peoples alliances, invalidated provisions regarding ADAT forest in Forestry Law. The Constitutional Court confirmed that ADAT forests located in indigenous territories should no longer be considered State Forests (Mahkamah Konstitusi Republik Indonesia 2013). This verdict opened up new political opportunities for ADAT peoples to secure territory and resources threatened by state and private interests (Astuti et al., 2016). It radically expands the rights of ADAT people as the ruling obligates the government to grant/return collective ownership of territories traditionally managed by ADAT people (Siscawati et al., 2017).

Three years after the issuance of MK 35, on December 30, 2016, the President of the Republic of Indonesia, Joko Widodo, officially granted hutan ADAT recognition to 9 indigenous groups with a total area of 13,122 ha. (Fanani, 2017 ; Gaol \& Dahlia, 2017; RAN, 2017). The President insisted that this was the first step in the government's political stance, the beginning of the administration efforts to recognize the rights of indigenous peoples (Fanani, 2017 ; Varagur, 2017). The Indonesian Government is committed to returning a total of 12.7 million hectares of land to local communities and indigenous peoples for sustainable forestry as being targeted in the RPJM (Medium Term Development Plan) 2015-2019, of which 20 percent will be taken from private concession areas (Astuti et al., 2016; Fanani, 2017 ; Johnson, 2015; RAN, 2017). However, AMAN claims that there are 40-70 million hectares of forest that should be returned to ADAT peoples as the rightful owners (Cahyadi, 2014b). 
Several NGOs have criticized the slow process of the transfer of rights. It took more than three years between the MK 35 ruling and the first transfers (RAN, 2017; Varagur, 2017). The government still seems reluctant to devolve rights to forests (Varagur, 2017). The Ministry of Environment and Forestry decrees, establishing customary forests, have yet to be released and the exact parameters of what they entail remain unclear (Mongabay, 2017). Moreover, a draft of a law on "Recognition and Protection of the Rights of Indigenous Peoples Bill" (RUU Pengakuan dan Perlindungan Hak Masyarakat Hukum ADAT-PPHMA), which was filed in the House of Representative (Dewan Perwakilan Rakyat) in April 2013, was still languishing in parliament in April 2018 (Chandra, 2018; Hidayat, 2018).

\subsection{Engaging with ADAT people: determinant factors}

The Constitutional Court Decision 35/2012 states that customary forest is no longer a part of state forest, and cannot be fully controlled by the government. This decision resulted in a drastic change in the political position of ADAT peoples in forest management. ADAT communities may have full access to manage and use their customary forests once their status has been verified. Following the verdict of the Constitutional Court, there has been a massive movement, even euphoria, of groups of people who consider themselves ADAT people in an effort to 'grab' the opportunity to own and manage forest areas. However, legitimate rights must be proven with evidence of their existence and the government will remain the key holder of the forest until it is returned to the rightful claimant/s. Thus, there must be careful scrutiny in the process of returning or granting of the rights to the ADAT forest in question if SFM is to be attained.

We discuss 2 factors that can determine the success of engaging with ADAT people on SFM: (1) the ADAT people concerned must be legitimate, and (2) they must have the financial and technical capacity to implement SFM.

\subsubsection{Legitimate status of ADAT communities.}

The legitimate status of the ADAT communities can be difficult to verify in terms of the regulations governing the rights to forests. This is particularly so if we adhere to the definition of a legal ADAT community, which states that the community must have ancestral connections and a special relationship with the environment and a value system that governs economic, political, social, and a legal institution (Arizona et al., 2013; Gauset et al., 2011; Muur, 2015; Nair, 2006; Royer et al., 2015). The community must be thoroughly investigated, supported by a legal framework, and substantial evidence must be provided to support their claim. Bosquet (2013), found that in countries with large, heterogeneous and difficult-to-reach indigenous populations, the 
question of the 'representativeness' often arises when engaging with indigenous people.

There are two issues to be considered in verifying ADAT status. The first issue is the genuineness of the 'indigenous people'. The broader acceptance of indigenous people's revival discourse and the existence of supporting legal regulations, have triggered the appearance of groups of people who claim indigeneity for impure motives (Badan Legislasi 2017; Chavers, 2014; Kuper, 2003; Linggasari, 2016; McKenna, 2016; Moeliono et al., 2010; Tribun bisnis, 2017). In the inaugural meeting of the Forum of Indigenous Peoples held in Geneva in 1996, there were 'gate-crashers' claiming that they too were indigenous under threat from their government, whose claims were proven to be false; they were subsequently removed from the meeting (Kuper, 2003). Such bogus claims are not new. In the USA, since the late 1960s, there have been people claiming to be 'Indians' (native Americans), for personal gain, with unclear ethnicity. Some of these imposters have risen to national prominence on the strength of their bogus Indian credentials (Chavers, 2014). The Australian news quoted a statement from a Queensland aboriginal leader, who said that there were numerous 'white blackfellas' who have falsely claimed aboriginal status for benefits that should go to genuine aborigines (McKenna, 2016). Grumblies (2013), during her research on the Wana people of Central Sulawesi, found the phenomena of 'an instant ADAT community'. The Wana people had not been part of the political movement of indigenous peoples, but the new and on-going interaction with certain NGOs has suddenly made them 'masyarakat ADAT'. The Indonesian Coordinating Minister for Economy, Darmin Nasution, noticed that there were people who had settled on state land and suddenly claimed to have the right to customary land with no valid proof (Tribun bisnis, 2017). Moeliono et al. (2010), cited the same issue in Kutai National Park (KNP), East Kalimantan, where groups of people who originated from other regions had settled in KNP after the designation of the KNP, claiming to be ADAT people. The Indonesian House of Representative has also indicated a similar concern. They highlighted the existence of a group acting on behalf of the ADAT people, for immediate economic and political purposes, which could harm existing traditions and customs (Badan Legislasi 2017).

The second issue concerns the loss of indigenous purity (Anthias, 2017; Huntington et al., 2004; Kothari, 2007; Luz et al., 2015; Muur, 2015). Being reputed as a self-sustaining community with a strong connection to the forest linked by norms, beliefs and traditions (Arizona et al., 2013; Li et al., 2010; Mulyoutami et al., 2009; Sasaoka et al., 2012; Wachira, 2010), these widely accepted premise of indigenous peoples are facing serious challenges, not least from anthropologists (Kuper, 2003). There have been numerous criticisms attacking overly exaggerated pictures of indigenous people 
(Grumblies, 2013; Muur, 2015). These critics relate to a premise that indigenous peoples have changed in line with changes in economic and environmental conditions. The increase in population and cultural diversity in the region, contact with external people with different values and attitudes, and an increasing need for cash, might change the general attitude of ADAT people towards nature (Anthias, 2017; Huntington et al., 2004; Kothari, 2007; Luz et al., 2015; Muur, 2015).

Klenke (2013), during her research in Tana Toraja, South Sulawesi, highlighted her concerns for the emerging loss of the indigenous purity of the ADAT people. She questioned why people, including the elite, who are local or from the region, even from elsewhere in the nation, would want to claim an identity that seems to make them marginal by definition. She also questioned the representativeness of ' $w e^{\prime}$ cultural/ADAT claims (Klenke, 2013). The notion of 'indigenous' has become politicized in a local arena under socialcultural and political-economic conditions (Royer et al., 2015).

Based on our observations of ADAT people in four villages around Gunung Lumut Protected Forest (GLPF), in Paser District, East Kalimantan, 20122014, we also found symptoms of the loss of 'indigenous purity'. The Lusan people, who claimed to be an ADAT people living in a territory covering 7,500 ha of ADAT forest, appointed a migrant from the Banjar tribe, South Kalimantan, as their ADAT leader because no native person was willing to take up the post. In the other villages, the different perspectives within the groups themselves about the idea of how customary forests should be managed colored the indigenous people's euphoria, in response to MK 35 . In Swan Slutung Village, there was a debate between politically weak ADAT leaders with the village head (formal administrative leader) about how their ADAT forest should be managed. According to the ADAT leaders, ADAT forest cannot be sold or rented to an outsider. However, the head of the village tended to invite investors to manage their forest. He said, "If there is no investor to manage the forest then the forest cannot support our livelihoods. If there are investors, there will be road access, benefits for the villagers and the economy and people's welfare will increase". In our meeting with the members of Rantau Layung Village in 2013, a year after MK 35 was introduced we noticed the same tendency. There were some village members who wanted to either convert the forest into plantations in cooperation with investors or sell it to industrial companies to gain short-term benefits from their forest. Pragmatism and capitalism also emerged in line with an increase in the need for cash, which changed the attitude towards nature. In Rantau Buta village, village members, with sufficient financial capacity, hired several Madurese to cut trees for direct economic gain from their claimed forested land and sold the extracted timber, permitted under swidden farming activities. Despite the restrictions in ADAT law to sell ADAT forest, several 
migrants in Rantau layung bought land close to the village parcel by parcel from the native people and planted permanent crops (rubber and oil palm), which left the natives farming in areas far from the village.

The Ministry of Home Affairs Regulation 52/2014, stipulates five indicators of indigeneity for official recognition of legal ADAT communities: (a) a history of the legal ADAT law-abiding community; (b) ADAT territory; (c) ADAT law; (d) ADAT property relations, inheritance and ADAT artifacts; and (e) a customary governance system. Nevertheless, looking at the existing rules (KATR/BPN, 2016; KEMENDAGRI, 2014; KLHK, 2015a; PSKL, 2016), the main approach to validate and verify the existence of ADAT peoples is still focused on a legal approach based on judicial and physical data.

There should be a verification mechanism with substantial evidence based on adequate and well-controlled investigation as an essential instrument for the recognition of ADAT rights to forest areas. In Figure 5.1 we depict the proposed process of verification of the ADAT people's legitimation by incorporating the analysis of substantial and admissible evidence.

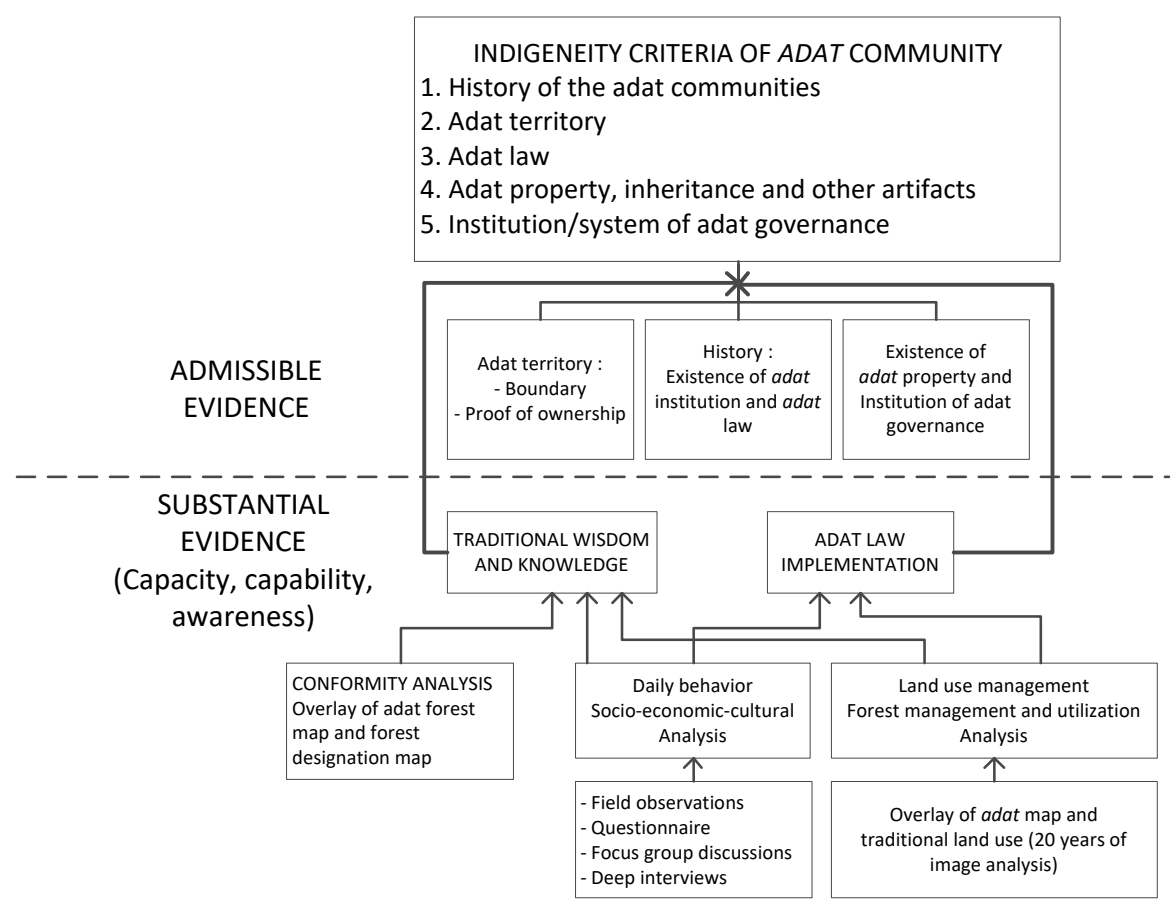

Figure 5. 1 Integrated verification process (Nugroho et al., 2018)

We are concerned that the recognition process will only become an instrument for political persuasion as mentioned by Kuper (2003), rather than being considered a tool for better management of forests. We consider 
that to rely merely on judicial and physical data is not enough to prove the indigeneity of the ADAT claimants' rights to forests.

Using a case study in Muluy and Rantau Layung, and including the two ADAT peoples living around Gunung Lumut Protection Forest (GLPF), East Kalimantan, Indonesia, 2010-2014, we tested the verification process of the capacity, capability and awareness of the ADAT people as the substantial evidence of the ADAT people's legitimate status. We focused on two approaches in analyzing substantial evidence, which consists of: 1) map conformity as an instrument to assess traditional knowledge, and 2) historical land-use patterns as an instrument to assess ADAT law implementation. By combining spatial analysis, field surveys, and socio-cultural analysis to assess the traditional knowledge and ADAT law implementations, as rationally as possible, we provide an overview of substantial evidence of the indigeneity as a basis for the transfer of rights to forest (Nugroho et al., 2018).

\subsubsection{Financial and technical capacity of the ADAT people in implementing SFM}

The financial and technical capacities of the ADAT people are significant factors in determining their ability to implement SFM (AMAN, 2012; Balsdon, 2007; Lininger, 2011; Safitri \& Bosko, 2002). Poverty reduces people's capacity to use resources in a sustainable manner; it intensifies pressure on the environment. Those who are poor and hungry will often destroy their immediate environment in order to survive: they cut down the forests, sell the timber and overuse the land. Balsdon (2007), mentioned that poverty per se causes short-sighted decisions and consequently environmentally destructive farming practices. Poverty is not only a problem for household income and basic needs, but frequently reduces time to participate in the development process of their environment (Safitri et al., 2002).

Coupled with limited financial capacity, a lack of technology has made it difficult for ADAT people living inside forest areas to secure their livelihoods. They are unable to afford better agricultural inputs and to increase land productivity while avoiding land degradation. Based on our field visit to Muluy and Rantau Layung, between 2010-2014, swidden farming practices were not used in soil and conservation measures. Clearing the forest on hill slopes using slash and burn at the beginning of the wet season has triggered erosion, the loss of soil nutrients and sedimentation in water bodies. The fallow land can also be susceptible to erosion, requiring a longer period for regeneration before the land is again suitable for cultivation (Balsdon, 2007). With higher population densities and increased land pressures, fallow periods become shorter, weeds and pests build up, and soil nutrients and land productivity decline, making the system unsustainable (Lininger, 2011). In 
the last few decades, the Muluy people's shifting cultivation cycle has been reduced from 20-30 years to 6-10 years due to the limited number of young villagers and the desire to open new land for oil palm and rubber (cash crop) plantations. The older generation is not physically capable of utilizing land far from the village. Interested in instant cash, the young have left the village in search of off-farm work in peri-urban areas or the logging industry and go back to the village with sufficient money to buy land for cash crop plantations (Nugroho et al., 2017).

The other problem is the shift in farming patterns. From our observations, we found that the need for cash has changed the villagers' behavior(Nugroho et al., 2017) . Many farmers have started to cultivate rubber or oil palm crops mixed with upland rice. This was also in line with general trends in many parts of the world where villagers have started to change their farming methods from shifting to permanent cultivation (Hariyadi \& Ticktin, 2012; Heinimann et al., 2013; Mertz, 2009). After 3 years, when the rubber/oil palm canopies block the sun and upland rice cannot grow, they start to clear new land for another plantation of mixed crops and will not return to the land after 15 years due to the presence of the rubber and oil palm. This means that each household needs to cut and clear either primary or secondary forest including inside GLPF every two to three years. Unfortunately, due to limited capacity in finance and farming technology, productivity has been very low. They cannot afford better quality seed, fertilizer and pest control. Instead of intensifying inputs to raise production, farmers tend to expand their land into forest areas (Nugroho et al., 2017). Although small farmers and shifting cultivators are not the main drivers of deforestation in regions where most deforestation takes place, they do contribute to it (Lininger, 2011). In 2008, several Rantau Layung people individually moved to alas ADAT (restricted forest areas, forbidden for swidden activities) close to the logging road, far from the original villages, to open new land for an oil palm plantation. The Muluy people were regarded as ADAT people with high levels of indigenous purity. In fact, based on spatial analysis in the last decade, they have started to utilize the forest area inside GLPF, on the left and right of the road outside their territory. Up to 2012, of 279 ha of the Muluy people's agricultural land, 103 hectares (37\%) were situated outside the ADAT forest area with an average growth rate of $12 \%$ /year creeping out from the villages and the agricultural area periphery, parcel by parcel, along the roadside.

To overcome the major shortfalls associated with land management, limited productivity and high negative impact on land degradation, there must be special measures that integrate traditional knowledge and scientific based knowledge. This would enable ADAT people to design a better future while maintaining forest sustainability. Traditional knowledge, local empirical knowledge, and know-how, have been passed down verbally from one 
generation to the next (Guidotti, 2007; Martinez, 2010; Mazzocchi, 2006). Over the centuries adaptive processes have evolved this knowledge and traditions (Mazzocchi, 2006; Snively et al., 2001) into what are considered the main characteristics of indigenous people (Juanwen et al., 2012; Kawharu, 2011; Kementerian PPN/BAPPENAS 2013). The word 'traditional' places the emphasis on the transmission of knowledge along a cultural continuity, but might ignore the ability of traditional societies to adapt to changing circumstances (Mazzocchi, 2006).

Since shifting cultivation has been part of ADAT culture for many generations (Hariyadi et al., 2012), the solution is not to force ADAT people to convert to permanent agricultural systems. Rather, to ensure the security of land rights, and help improve their shifting cultivation with better farming inputs and technology, together with longer fallows, to maintain soil fertility so it is more productive. Traditional land-use systems are feasible when physical constraints make modern agriculture impossible (Plieninger et al., 2006). Long-term security and short-term consumption of agricultural commodities should be optimized through the combination of land management and local institutional enforcement. Land-use management that enhances farming income while avoiding deforestation and degradation must be promoted, supported by land allocation, and the implementation of formal laws that respect ADAT law and revitalize ADAT institutions. The approach must emphasize the active participation of the ADAT people, site specific and farmer centric. Stakeholder involvement is a must; particularly farmers in deciding the feasible technologies to be transferred. This can be achieved in a participatory mode with active farmer participation and feedback about their choices regarding the adoption of technology, and marrying traditional and scientific based knowledge.

\subsection{Building long term engagement : coping with constraints and challenges}

Engagement with indigenous peoples, in some countries, is supported by formal agreements or protocols for engagement. However, persistent problems in engaging with indigenous people is frequently the failure of governments to commit to policies and processes that they have established (Human Rights Equal Opportunity Commission 2005).

The Ministry of Environment and Forestry Decrees on the establishment of nine ADAT forests (Kajang, Marga Serampas, Wana Posangke, Bukit Sembahyang, Kasepuhan Karang, Bukit Tinggai, Tigo Luhah Permenti yang Berenam, Tigo Luhah Kemantan, and Tombak Haminjon) stipulates that ADAT forests must be managed in accordance with the established basic functions and cannot be traded either now or at any time in the future 
(Menteri Lingkungan Hidup dan Kehutanan 2016). This is in line with the UN General Assembly resolution 1803 (XVII) in 1962: "Permanent sovereignty over natural resources", states that the exploration, development, and disposition of such resources should conform to the rules and conditions with regard to the authorization, restriction or prohibition of such activities (Daes, 2004).

The government and ADAT people will be confronted with various dilemmas. Granting ADAT communities ownership rights to ADAT forests, mandated by law, is a welcomed step in the right direction. However, potential conflict and other problems associated with the implementation of this law, due to the varying interests of individuals and groups, must be carefully considered and monitored. At the same time, ADAT people will also face their own dilemmas: opposing tensions in ADAT law and pragmatic desires, different drivers, motivations, and interests of the group members.

While conducting our research in GLPF, we noticed three main constraints and challenges in developing long-term effective engagement with ADAT peoples. The first constraint relates to the potential conflict due to the strict use of indigenous people's terms in the recognition of ADAT forests; the second is the existence of regulations requiring local regulations and customary forest maps to support the recognition process; and the third are factors related to the actual condition of the ADAT people: the loss of ADAT purity (Anthias, 2017; Huntington et al., 2004; Klenke, 2013; Kothari, 2007; Luz et al., 2015; Muur, 2015), the weak institutional capacity (Chino \& DeBruyn, 2006; Escott et al., 2015; Tinus et al., 2014; Yunitasari, 2009), the ADAT people's distrust and skepticism of the state (Adji, 2016; Bond et al., 2012; Human Rights Council 2014; Mongabay, 2015), and the tendency for economic pragmatism (Fleming, 2015; Murniati et al., 2006; Nugroho et al., 2017; Wahyuni, 2011) of present-day ADAT people.

The first challenge is the potential conflict following the handing over of full management of a forest area to the defined ADAT people whose rights are based on a formal regulation. Favoring the concept of ADAT and formalizing community exploitation and management rights of forest in keeping with legal terminology of a legal ADAT community, carries the risk of only including certain groups that have historically occupied discrete and exclusive territories. The formalization of customary land ownership arrangements can exclude 'non-indigenous' groups inside and outside the village community, potentially driving them further to marginal livelihoods and positions of social, cultural and economic inequality (Royer et al., 2015). Henley et al. (2007), noticed that one important dimension of the current ADAT revival, at the local level, is the exclusion of the outsider (immigrant), which has ignored their rights, destroyed their livelihoods, and labeled them outsiders. Modern 
politics concerning ADAT peoples comes down to the difference between insiders (pribumi) and outsiders (pendatang) (Henley et al., 2007). The interpretation of indigenous peoples as masyarakat ADAT (ADAT community) rather than penduduk asli (native inhabitants) actually implies less emphasis on blood and soil and more on tradition and community than is usual in the international movement (Henley et al., 2007).

Yet, the two different terms regulating the same issue have appeared in two important Indonesian laws related to forestry and spatial planning. Law 41/1999 on Forestry and Law 26/2007 on Spatial Planning and its derivative rule (PP 26/2008 on National Spatial Planning), use different terms to determine who has the rights to utilize protected forest areas. Law 41/2009 explicitly states that the "right" to forest areas belongs to "masyarakat ADAT" (ADAT communities). This is also in-line with the Agrarian Ministry Regulation 5/1999, with a complete explanation, whereas in PP 26/2008 on RTRWN (article 99 subsection (1) point c) uses the term "masyarakat asli" (native peoples) without any explanation.

Even before the issuance of $\mathrm{MK}$ 35/2013, conflicts between indigenous peoples and migrants have occurred in various regions of Indonesia at the time of the massive ADAT revival era, especially after the fall of Indonesia's New Order, in the name of marginalization and ADAT rights (Fanselow, 2014; Henley et al., 2007; Smith, 2005; Wulan et al., 2004). Often these conflicts occur between communities who share similar status and ability to push their claims, and are equally protected by the rules to live in the same areas.

In 1905, during the colonial era in Indonesia, a transmigration program was introduced to relocate non indigenous people to indigenous land, on the outer islands, in an effort to reduce the population on highly populated islands, particularly Java and Bali (DBPKT, 2015; Henley et al., 2007; McKinnon, 2012; UNPO, 2014). The migrants, who have been living in a certain area for two-three generations, consider themselves native people. Outbreaks of ethnic-based conflict between indigenous ethnic groups and immigrants from other parts of Indonesia have regularly occurred in Kalimantan since the 1970s. These escalated greatly immediately after the reformation era, and the end of Suharto's New Order (Fanselow, 2014). Acts of horrific violence, in the name of ADAT, occurred in West Kalimantan in 1996, 1997 and 1999, and Central Kalimantan in 2001, resulting in tens of thousands of Madurese settlers being expelled from their homes where they had lived for decades (Henley et al., 2007; Smith, 2005). Instead of a case of economic competition or conflict based on economic differences as being justified by many scientists, the Dayaks interpreted the conflicts as a 'clash of cultures' and believe they can only be resolved and managed within the framework of conflict resolution methods available in the Dayak culture (Fanselow, 2014). 
The second challenge is related to the implementation of government regulations concerning the verification and validation procedures. Based on the Ministry of Environment and Forestry Regulation P.32/MenlhkSetjen/2015 on titled forest (KLHK, 2015a), and the Director of Social Forestry and Environmental Partnership Regulation P.1/PSKL/Set/Kum/1/2/2016 on the procedure of verification and validation of titled forest (PSKL, 2016), the application for the rights to ADAT forest may commence if there is a legal product at the regional level that establishes the recognition of the legal ADAT community, and supported by ADAT forest maps as authentic evidence (KLHK, 2015a; Linggasari, 2015; PSKL, 2016).

Fulfilling such prerequisites is a complicated, time consuming, and risky process. The mapping process of ADAT forests and absence of local regulations to enforce MK 35 ruling protecting indigenous forests, are among other factors that slow down the transfer process of rights (Varagur, 2017). AMAN estimates that approximately 40-70 million hectares of Indonesian State forest land should be under customary control (Cahyadi, 2014b; Myers et al., 2017), in which ADAT communities are required to prove their existence supported by authentic evidence to claim their traditional territory (Boedhihartono, 2017; Gaung AMAN 2015; Siscawati et al., 2017).

In the last two decades, millions of hectares of forest across 25 provinces have been mapped by communities with the help of Non-Government Organizations (NGO) to make land claims (AMAN, 2016; Astuti et al., 2016; Mongabay, 2017; Varagur, 2017). They hope to have mapped 40 million hectares by 2020 (Tessier et al., 2016). "Map your ancestral territory before it is mapped by others...!" is a provocative slogan AMAN uses to encourage its community members to start mapping their land as an essential response to MK 35 (Astuti et al., 2016; Gaung AMAN 2015; Tessier et al., 2016).

This euphoria has increased the desire of indigenous peoples to immediately make claims to customary territories even in areas far from their present location. During our research in GLPF, we noticed that there was a tendency to push ADAT forest mapping even though in reality these indigenous peoples have no historical records of the boundaries of their territory. In a meeting of several groups of ADAT communities in Kampung Muara Payang, Paser District, in 2009, ADAT leaders, guided by a local NGO, unilaterally set-up ADAT forest areas in several villages (Padi Indonesia 2010).

The use of maps made by indigenous peoples as the basis for claims on customary forests, has the potential to generate conflict. For example, the Muluy ADAT map, covering an area of $12,953 \mathrm{ha}$, includes a transmigration 
area (Swan Slutung Village) and timber plantations far from their present settlement (Figure 5.2).

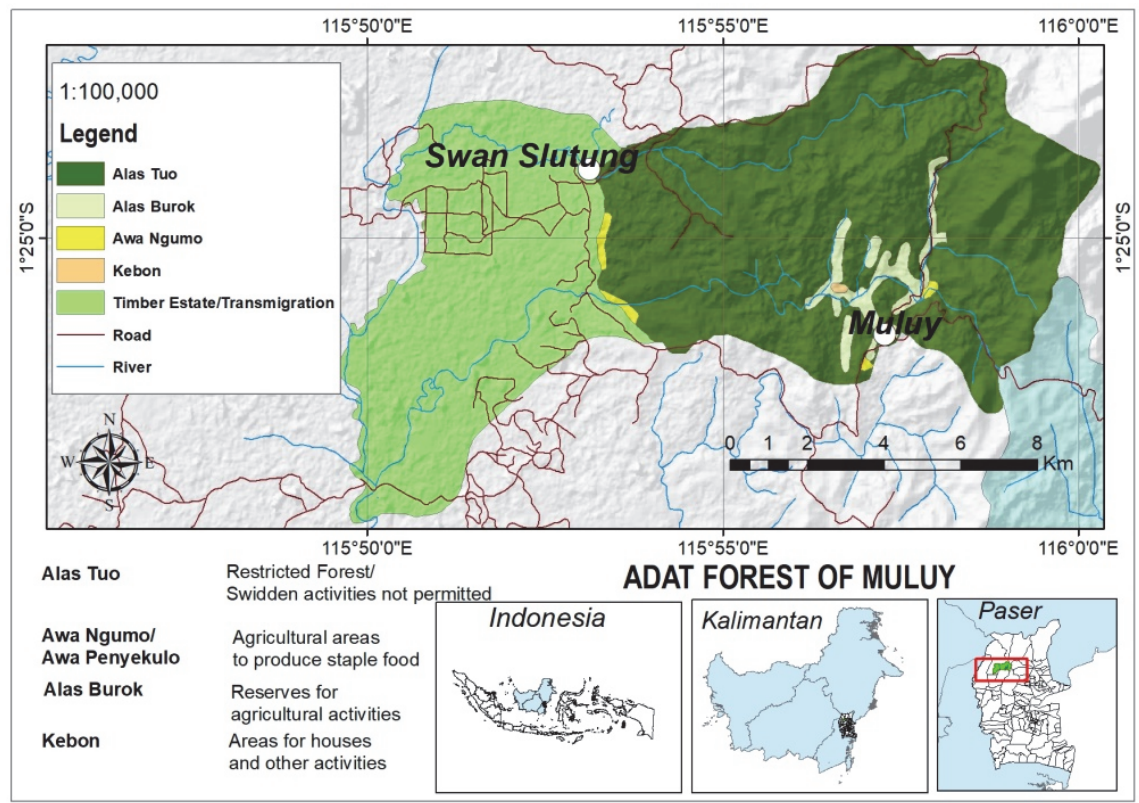

Figure 5. 2. ADAT Forets of Muluy

The most arduous task, concerning the regulation governing the transfer of rights, is to produce maps of ADAT forests/territory that show conflicting land uses, redefined territory boundaries and to identify potential law violations. The validation and verification process for an indigenous people's territory should be able to depict potential conflicts and potential violations of existing regulations.

The third challenge concerns factors related to the actual condition of the ADAT people. The loss of indigeneity (Anthias, 2017; Huntington et al., 2004; Kothari, 2007; Luz et al., 2015; Muur, 2015), low capacity, distrust of the government, and the economic pragmatism of the ADAT people today, are some of the most important factors that could spell the failure of long-term engagement with these communities.

Based on our observations of ADAT peoples in GLPF, we found that without the intervention of the government or other competent parties, the existing indigenous peoples institutions are not able to function optimally to ensure good forest management. This is related to several factors such as the dominance of the local elites, apathy and the pragmatic attitude of some members of the ADAT communities, and strong interference from outsiders with economic as well as political motives. These findings are in line with 
findings mentioned by several scholars. Yunitasari (2009) and Deijl (2014) found that the dominance of the local elites in decision making resulted in the government's community empowerment program being discontinued due to the limited participation of ADAT members in decision making.

We suggest that various parties, especially the government and ADAT people, should take an active role in developing collective actions to ensure that the ADAT forest will be managed sustainably by building capacity (institutional, technical and financial) and trust and promoting dialogue. The rights to natural resources should be an instrument of the alleviation of poverty, physical and cultural survival, and ADAT law-based social and economic development. ADAT law must be revitalized and empowered in accordance with the enforcement of formal, state regulations. Herlina Hartanto et al. (2008), found that by triggering a series of dynamic adaptation at the local level, state intervention strengthened and expanded, rather than eroded customary institutions and authority over natural resources.

There is significant evidence that culture-aligned economies are more effective long term when engaging with indigenous people who live in remote areas (Fleming, 2015). Fleming concluded that a successful indigenous economy is not a matter of which economies to support, but how to support them (Fleming, 2015). However, the conceptualization and implementation of capacity building strategies should be based on the balance between introduced frameworks and traditional ADAT knowledge.

The current literature identifies various dimensions of capacity, such as participation, leadership, social support, sense of community, access to resources and skills, and their importance in developing and empowering local coalitions (Chino et al., 2006). Chino and DeBruyn (2006), also mentioned several additions to community capacity to be empowered such as the readiness of a community to work to improve existing conditions, and the social capital necessary for communities to move forward and collaborate in both traditional and dominant cultures.

In 2015, the Indonesian government committed to the redistribution of ownership and control over nearly 22 million hectares of land, or equivalent to 12 per cent of the country's land area, by 2019; 12.7 million ha of land in forest areas through the social forestry scheme and nine million through redistribution and certification of land ownership, referred to as Land Object for Agrarian Reform (Tanah Objek untuk Reforma Agraria-TORA). The constraints and challenges must be overcome before moving forward. There must be continuous dialog to maintain commitment after the transfer of ownership rights to the forest areas. Otherwise, instead of attaining SFM, the 
transfer of rights to forest will be a catalyst for impoverishment and forest destruction, and Indonesia's last remaining forests will disappear.

\subsection{Concluding Remarks}

Communicating with indigenous peoples living in forest areas is much more complicated than with those living outside forests. The widely accepted positive image of indigenous people as a self-sustaining community with a strong connection to the forest linked by norms, beliefs, and traditions has been questioned as many scientists begin to doubt its validity (Grumblies, 2013; Kuper, 2003; Muur, 2015).

Engaging with legitimate ADAT people, who wish to manage their ADAT forest, is a basic condition required if SFM goals are to be achieved and longterm conflicts avoided in the future. A partial or sectoral formal approach with limited participation of ADAT people as well as 'non-indigenous' people, will not work to foster long-term engagement. There must be substantial (logic and reasonable) evidence obtained from adequate and well-controlled investigation, instead of only admissible evidence, before the rights to land is transferred to the targeted people. The biggest concerns that must be addressed include: 1 ) the provision of detailed verification of two aspects of the representativeness, a prerequisite for indigenous people's legitimate status and their capacity to manage the forest sustainably, 2) anticipation of potential conflict when strict use of indigenous people's terms are used and unilateral claims to territory are made, and 3) supervision, assistance, building the institution, technical and financial capacity of the ADAT people to manage and utilize their customary forests sustainably, and to promote continuous dialog to maintain the established commitments.

\subsection{Acknowledgement}

This work was prepared based upon a collaborative research project between the Forestry Research and Development Agency, Tropenbos International Indonesia Program, Faculty of ITC University of Twente and Mulawarman University in East Kalimantan, between 2008 and 2012, entitled "Integrating Customary Rights and Traditional Land Use into Spatial Planning: The Use of Appropriate Modelling for Decision Support Systems". No PIS. 50100020. We thank the people of Muluy, Rantau Buta, Rantau Layung, Lusan, and Swan Slutung for their support during our fieldwork. The authors would like to thank Glen Mulcahy for the revision of the article from a linguistic point of view. 


\section{References}

Adji, B. (2016). Penetapan Kawasan Hutan ADAT Dinilai Lamban. 5 Desember 2016. Retrieved 30 Maret 2018, 2018, from http://www.harnas.co/2016/12/05/penetapan-kawasan-hutan-ADATdinilai-lamban

Affandi, D. Y. (2016). Negoitating ADAT. 22 Fepbruary 2016. Retrieved 20 September 2017, 2017, from http://www.insideindonesia.org/negotiating-ADAT

AMAN. (2012). REPUBLIC OF INDONESIA Country Technical Notes on Indigenous Peoples' Issues: IFAD.

AMAN. (2014). 2013 in Review Indigenous Peoples' Alliance of the Archipelago 28 February 2014. Retrieved 22 November 2016, 2016, from http://www.aman.or.id/2014/02/28/2013-in-review-indigenouspeoples-alliance-of-the-archipelago-aliansi-masyarakat-ADATnusantara-aman/

AMAN. (2016). 8,28 Juta Hektar Peta Wilayah ADAT Secara Resmi Diserahkan Kepada Pemerintah. 23 November 2017 Retrieved 18 September 2017, 2017, from http://www.aman.or.id/828-juta-hektar-petawilayah-ADAT-secara-resmi-diserahkan-kepada-pemerintah/

AMAN and AIPP (2017, April - May 2017). Joint Stakeholders' Submission on The Situation of Human Rights of Indigenous Peoples in Indonesia. 3rd Cycle of Universal Periodic Review of Indonesia; 27th Session of the Human Rights Council. Jakarta - Ciang Mai.

Anthias, P. (2017). Ch'ixi landscapes: Indigeneity and capitalism in the Bolivian Chaco. Geoforum, 82(Supplement C), 268-275. doi: https://doi.org/10.1016/j.geoforum.2016.09.013

Ardanaz, M., Leiras, M., \& Tommasi, M. (2014). The Politics of Federalism in Argentina and its Implications for Governance and Accountability. World Development, 53, 26-45. doi: http://dx.doi.org/10.1016/j.worlddev.2013.01.004

Arizona, Y., \& Cahyadi, E. (2013). The Revival of Indigenous Peoples: Contestations over a Special Legislation on Masyarakat ADAT. In B. Hauser-Schäublin (Ed.), ADAT and Indigeneity in Indonesia Culture and Entitlements between Heteronomy and Self-Ascription (Vol. 7, pp. 43-62). Göttingen: Göttingen University Press

Astuti, R., \& McGregor, A. (2016). Indigenous land claims or green grabs? Inclusions and exclusions within forest carbon politics in Indonesia. The Journal of Peasant Studies, 1-22. doi: 10.1080/03066150.2016.1197908

Badan Legislasi (2017). Mempolitisir Masyarakat ADAT Merusak Tatanan. 13 September 2017. Retrieved 14 October 2017, 2017, from http://www.dpr.go.id/berita/detail/id/17628/t/Mempolitisir+Masyarak at+ADAT+Merusak+Tatanan 
Bakker, L. (2008, April 25-26). "Can We Get Hak Ulayat?": Land and Community in Pasir and Nunukan, East Kalimantan. Paper presented at the UC Berkeley-UCLA Joint Conference on Southeast Asia, "Ten Years After: Reformasi and New Social Movements in Indonesia, 1998-2008", The University of California Berkeley, California.

Balsdon, E. M. (2007). Poverty and the management of natural resources: A model of shifting cultivation. Structural Change and Economic Dynamics, 18(3), 333-347. doi: https://doi.org/10.1016/j.strueco.2006.12.001

Banjade, M. R., Herawati, T., Liswanti, N., \& Mwangi, E. (2016) Tenure reform in Indonesia, When? What? Why? , iNFO bRIEF: Vol. 163 (December 2016 ed.). Bogor: CIFOR.

Barr, C., Wollenberg, E., Limberg, G., Anau, N., Iwan, R., Sudana, I. M., . . . Djogo, T. (2001). The impacts of decentralisation on forests and forest-dependent communities in Malinau district, East Kalimantan. Bogor, Indonesia: CIFOR.

Blaser, J. (2010). Forest law compliance and governance in tropical countries, A region-by-region assessment of the status of forest law compliance and governance, and recommendations for improvement. In A. Sarre (Ed.), (pp. 1-28): FAO and ITTO.

Boafo, J. (2013). The Impact of Deforestation on Forest Livelihoods in Ghana. BACKGROUNDER. AFRICAPORTAL. Retrieved from http://www.africaportal.org/sites/default/files/Africa\%20Portal\%20Ba ckgrounder\%20No.\%2049.pdf

Boedhihartono, A. K. (2017). Can Community Forests Be Compatible With Biodiversity Conservation in Indonesia? Land 6, 21, 17 . doi: 10.3390/land6010021

Bond, C., Brough, M., Spurling, G., \& Hayman, N. (2012). 'It had to be my choice' Indigenous smoking cessation and negotiations of risk, resistance and resilience. Health, Risk \& Society, 14(6), 565-581. doi: 10.1080/13698575.2012.701274

Bonsu, N. O., Dhubháin, Á. N., \& O'Connor, D. (2015). Understanding forest resource conflicts in Ireland: A case study approach. Land Use Policy. doi: https://doi.org/10.1016/j.landusepol.2015.11.009

Bonsu, N. O., Dhubháin, Á. N., \& O'Connor, D. (2017). Evaluating the use of an integrated forest land-use planning approach in addressing forest ecosystem services conflicting demands: Experience within an Irish forest landscape. Futures, 86(Supplement C), 1-17. doi: https://doi.org/10.1016/j.futures.2016.08.004

Bosquet, B. (2013). Engaging with Indigenous Peoples on forests. Development in a Changing Climate. 41 February 2017. Retrieved 30 September 2017, 2017, from http://blogs.worldbank.org/climatechange/engaging-indigenouspeoples-forests 
BPS. (2010). Kewarganegaraan, Suku Bangsa, Agama, dan Bahasa Seharihari Penduduk Indonesia, Hasil Sensus Penduduk 2010. Jakarta: Subdirektorat Statistik Demografi, Badan Pusat Statistik.

BPS Kabupaten Pasir (2011). Kabupaten Pasir Dalam Angka 2011. Tanah Grogot: Badan Pusat Statistik Kabupaten Pasir.

Bressers, H. T. A., \& Kuks, S. M. M. (2003). What does governance mean? From conception to elaboration. In H. T. A. Bressers \& W. A. Rosenbaum (Eds.), Achieving Sustainable development: The challenge of Governance Across Social Scales (pp. 43-64.). Westport Connecticut: Praeger Publishers

Cahyadi, F. (Producer). (2014a, November 21, 2014 ). Indigenous People as Victim of Law on on the Prevention and Eradication of Forest Destruction. Retrieved from http://www.aman.or.id/en/2014/11/21/indigenous-people-as-victimof-law-on-on-the-prevention-and-eradication-of-forest-destruction/

Cahyadi, F. (2014b). Pidato Sekretaris Jenderal (Sekjen) AMAN \#HKMAN2014. 18/03/2014. Retrieved 16 September 2017, 2017, from http://www.aman.or.id/pidato-sekretaris-jenderal-sekjen-amanhkman2014/

Cahyadi, F. (2014c). Satgas Nasional Pengakuan dan Perlindungan Masyarakat ADAT Mulai Dibentuk. 17 November 2014. Retrieved 9 February 2017, 2017, from https://www.aman.or.id/2014/11/17/satgas-nasional-pengakuandan-perlindungan-masyarakat-ADAT-mulai-dibentuk/

Carothers, T., \& Brechenmacher, S. (2014). Accountability, transparency, participation, and inclusion, a new development consensus? Washington DC: Carnegie Endowment for International Peace.

Chandra, W. (2018). RUU Masyarakat ADAT Versi DPR Berpotensi Hilangkan Keberadaan Masyarakat ADAT. 24 May 2018. Retrieved 24 Agustus 2018, 2018, from http://www.mongabay.co.id/2018/05/24/ruumasyarakat-ADAT-versi-dpr-berpotensi-hilangkan-keberadaanmasyarakat-ADAT/

Chavers, D. (2014). 5 Fake Indians: Checking a Box Doesn't Make You Native, Census data about Native Americans is often misleading. October 15, 2014. Retrieved 14 October 2017, 2017, from https://indiancountrymedianetwork.com/history/events/5-fakeindians-checking-a-box-doesnt-make-you-native/

Chino, M., \& DeBruyn, L. (2006). Building True Capacity: Indigenous Models for Indigenous Communities. American Journal of Public Health, 96(4), 596-599. doi: 10.2105/ajph.2004.053801

Chun, J. (2014). A legal approach to induce the traditional knowledge of forest resources. Forest Policy and Economics, 38(0), 40-45. doi: http://dx.doi.org/10.1016/j.forpol.2012.07.006 
Cimpoeru, M. V., \& Cimpoeru, V. (2015). Budgetary Transparency - An Improving Factor for Corruption Control and Economic Performance. Procedia Economics and Finance, 27, 579-586. doi: http://dx.doi.org/10.1016/S2212-5671(15)01036-9

Coutant, D., Riggs, D., \& Van Sant Hoffman, E. (2011). Substantial Evidence: When is a Single Trial Sufficient for Approval and Promotion? Drug Information Journal, 45(3), 253-263. doi: $10.1177 / 009286151104500306$

CPF. (2012). SFM and indigenous peoples (Vol. SFM fact sheet 4): Collaborative Partnership on Forest.

Daes, E.-I. A. (2004). Indigenous Peoples Permanent Sovereignty Over Natural Resources. Paper presented at the National Native Title Conference, Adelide. https://www.humanrights.gov.au/news/speeches/indigenouspeoples-permanent-sovereignty-over-natural-resources

DBPKT. (2015). Transmigrasi, masa dulu, kini, dan harapan ke depan. Jakarta: Direktorat Bina Potensi Kawasan Transmigrasi, Direktorat Jenderal Penyiapan Kawasan dan Pembangunan Pemukiman Transmigrasi, Kementerian Desa, Pembangunan Derah Tertinggal dan Transmigrasi.

Defries, R., Hansen, A., Turner, B. L., Reid, R., \& Liu, J. (2007). Land Use Change around Protected Areas: Management to Balance Human Needs and Ecological Function. Ecological Applications, 17(4), 10311038. doi: $10.2307 / 40061895$

Deijl, C. M. (2014). Local Governance and Contemporary Development in Indonesia: The Long Shadow of the ADAT Law. (Master), The University of Warwick, Coventry, England.

Drazkiewicz, A., Challies, E., \& Newig, J. (2015). Public participation and local environmental planning: Testing factors influencing decision quality and implementation in four case studies from Germany. Land Use Policy, 46, 211-222. doi: http://dx.doi.org/10.1016/j.landusepol.2015.02.010

Easterly, W. (2000). Can Institutions Resolve Ethnic Conflict? Economic Development and Cultural Change, 49(4), 687-706. doi: $10.1086 / 452521$

Escott, H., Beavis, S., \& Reeves, A. (2015). Incentives and constraints to Indigenous engagement in water management. Land Use Policy, 49(Supplement C), 382-393. doi: https://doi.org/10.1016/j.landusepol.2015.08.003

Fanani, A. K. (2017). Hutan ADAT yang kembali ke pangkuan masyarakat. Senin, 9 Januari 2017 Retrieved 22/8/2017, 2017, from http://www.antaranews.com/berita/605551/hutan-ADAT-yangkembali-ke-pangkuan-masyarakat 
Fanselow, F. (2014). Indigenous and Anthropological Theories of Ethnic Conflict in Kalimantan. ZINBUN, 45, 131-147. doi: https://dx.doi.org/10.14989/197513

FAO. (2017). Sustainable forest management. Natural Forest Management. 2 May 2017. Retrieved 30 September 2017, 2017, from http://www.fao.org/forestry/sfm/en/

Fleming, A. E. (2015). Improving Business Investment Confidence in CultureAligned Indigenous Economies in Remote Australian Communities: A Business Support Framework to Better Inform Government Programs. The International Indigenous Policy Journal, 6(3 (5)). doi: 10.18584/iipj.2015.6.3.5

FPP, Pusaka, \& Pokker SHK (2014). Securing Forests Securing Rights, Report of the International Workshop on Deforestation and the Rights of Forest Peoples. Palangkaraya: Forest People Programme, Pusaka, and Kelompok Kerja Sistem Hutan Kerakyatan.

Fung, B. (2014). The Demand and Need for Transparency and Disclosure in Corporate Governance. Universal Journal of Management, 2(2), 7280.

Gaol, A. L., \& Dahlia, L. (2017). Indonesian president hands over management of forests to indigenous people. Forest News. Analysis. 20 February 2017. Retrieved 18 September 2017, 2017, from https://forestsnews.cifor.org/48323/indonesian-president-handsover-management-of-forests-to-indigenous-people?fnl=en

Gaung AMAN (2015). Petakan Wilayah ADATmu sebelum Orang Lain Memetakannya. Sejarah, Budaya, ADAT IstiADAT tak Terpisahkan. 9 Oktober 2015. Retrieved 16 September 2016, 2017, from http://gaung.aman.or.id/2015/10/09/petakan-wilyah-ADATmusebelum-orang-lain-memetakannya/

Gauset, Q., Kenrick, J., \& Gibb, R. (2011). Indigeneity and autochthony: a couple of false twins? Social Anthropology/Anthropologie Sociale, 19 (2), 135-142. doi: 10.1111/j.1469-8676.2011.00144.x

Gautier, D., Garcia, C., Negi, S., \& Wardell, D. A. (2015). The limits and failures of existing forest governance standards in semi-arid contexts. International Forestry Review, 17(S2), 114-126.

Gbedomon, R. C., Floquet, A., Mongbo, R., Salako, V. K., Fandohan, A. B., Assogbadjo, A. E., \& Glèlè Kakaï, R. (2016). Socio-economic and ecological outcomes of community based forest management: A case study from Tobé-Kpobidon forest in Benin, Western Africa. Forest Policy and Economics, 64(Supplement C), 46-55. doi: https://doi.org/10.1016/j.forpol.2016.01.001

Gooda, M. (2010). Social Justice and Aboriginal and Torres Strait Islander peoples access to services. Paper presented at the QCOSS Regional Conference: Building a Better Future-themed around improving service delivery for regional and remote communities. 
https://www.humanrights.gov.au/news/speeches/social-justice-andaboriginal-and-torres-strait-islander-peoples-access-services-2010

Grošelj, P., Hodges, D. G., \& Zadnik Stirn, L. (2016). Participatory and multicriteria analysis for forest (ecosystem) management: A case study of Pohorje, Slovenia. Forest Policy and Economics, 71(Supplement C), 80-86. doi: https://doi.org/10.1016/j.forpol.2015.05.006

Grumblies, A.-T. (2013). Being Wana, Becoming an "Indigenous People". Experimenting with Indigeneity in Central Sulawesi. In B. HauserSchäublin (Ed.), ADAT and Indigeneity in Indonesia Culture and Entitlements between Heteronomy and Self-Ascription (Vol. 7, pp. 82-98). Göttingen: Göttingen University Press

Grydehøj, A., \& Ou, Z. (2017). Deterritorialization of indigeneity: Indigenous territory, development policy, and the Dan fishing community of Hainan (China). Political Geography, 61(Supplement C), 77-87. doi: https://doi.org/10.1016/j.polgeo.2017.07.002

Guidotti, T. L. (2007). Traditional Knowledge: Challenge or Complement to Science? Archives of Environmental \& Occupational Health, 62(4), 167-168. doi: 10.3200/AEOH.62.4.167-168

Hariyadi, B., \& Ticktin, T. (2012). From Shifting Cultivation to Cinnamon Agroforestry: Changing Agricultural Practices Among the Serampas in the Kerinci Seblat National Park, Indonesia. Human Ecology, 40(2), 315-325. doi: 10.1007/s10745-012-9481-8

Hartanto, H., Rangan, H., Thorburn, C., \& Christian, K. (2008). Strategic Engagement and Dynamic Adaption: Customary Forest Management in Kerinci, Central Sumatra, Indonesia. Paper presented at the The 12th Biennial Conference of the International Association for the Study of Commons, Cheltenham, UK.

Hartanto, H., Rangan, H., Thorburn, C., \& Kull, C. (2008). Strategic Engagement and Dynamic Adaptation : Customary Forest Management in Keribci, Central Sumatra, Indonesia. Paper presented at the The 12th Biennial Conference of the International Association for the Study of Commons, England.

Heinimann, A., Hett, C., Hurni, K., Messerli, P., Epprecht, M., Jorgensen, L., \& Breu, T. (2013). Socio-Economic Perspectives on Shifting Cultivation Landscapes in Northern Laos. Human Ecology, 41(1), 51-62. doi: $10.1007 / \mathrm{s} 10745-013-9564-1$

Henley, D., \& Davidson, J. S. (2007). Introduction: radical conservatism - the protean politics of ADAT. In J. S. Davidson \& D. Henley (Eds.), The Revival of Tradition in Indonesian, Politics The deployment of ADAT from colonialism to indigenism (pp. 1-49). New York: Routledge

Heuer, M. (2011). Ecosystem Cross-Sector Collaboration: Conceptualizing an Adaptive Approach to Sustainability Governance. Business Strategy and the Environment, 20(4), 211-221. doi: 10.1002/bse.673 
Hidayat, Y. (2018). Penantian Panjang RUU Masyarakat ADAT. 17 April 2018. Retrieved 24 Agustus 2018, 2018, from https://news.detik.com/kolom/d-3975715/penantian-panjang-ruumasyarakat-ADAT

Holmes, B. (2011) Citizens' engagement in policymaking and the design of public services. Vol. Research Paper No. 1, 2011-12 (22 July 2011 ed.). Canberra, Australia: Department of Parliamentary Services.

Human Rights Council (2014). The situation of indigenous peoples in Canada Report of the Special Rapporteur on the rights of indigenous peoples, James Anaya: Human Rights Council, General Assembly, The United Nations.

Human Rights Equal Opportunity Commission (2005). Guidelines for engagement with indigenous peoples. Paper presented at the United Nations Workshop - International Conference on Engaging Communities - Brisbane, Australia, Brisbane, Australia.

Hunt, J. (2013). Engaging with Indigenous Australia-exploring the conditions for effective relationships with Aboriginal and Torres Strait Islander communities Issues paper no. 5. Produced for the Closing the Gap Clearinghouse. (pp. 53). Canberra: Australian Institute of Health and Welfare \& Melbourne: Australian Institute of Family Studies.

Huntington, H., Callaghan, T., Fox, S., \& Krupnik, I. (2004). Matching traditional and scientific observations to detect environmental change: A discussion on Arctic terrestrial ecosystems. Ambio(13), 1823.

ITTO. (2017). Sustainable forest management. Retrieved 30 September 2017, 2017, from http://www.itto.int/sustainable_forest_management/

IWGIA. (2011). Update 2011 - Indonesia. The Indigenous World, Asia. Retrieved 13 May, 2013, from http://www.iwgia.org/regions/asia/indonesia/871-update-2011indonesia

IWGIA. (2016). The Indigenous World 2016 (D. V. a. C. Mikkelsen Ed.). Copenhagen: The International Work Group for Indigenous Affairs.

Johnson, C. (2015). Indonesia: Declaration on Rights of Indigenous People to Forests. 29 April 2015. Retrieved 22 November 2016, 2016, from http://www.loc.gov/law/foreign-news/article/indonesia-declarationon-rights-of-indigenous-people-to-forests/

Jordan, A., Wurzel, R. K. W., \& Zito, A. (2005). The Rise of 'New' Policy Instruments in Comparative Perspective: Has Governance Eclipsed Government? Political Studies, 53(3), 477-496. doi: 10.1111/j.14679248.2005.00540.x

Juanwen, Y., Quanxin, W., \& Jinlong, L. (2012). Understanding indigenous knowledge in sustainable management of natural resources in China: Taking two villages from Guizhou Province as a case. Forest Policy 


$$
\text { and Economics, 22(0), 47-52. doi: }
$$

http://dx.doi.org/10.1016/j.forpol.2012.02.012

KATR/BPN. (2015). Tata Cara Penentuan Hak Komunal atas Tanah Masyarakat Hukum ADAT dan Masyarakat yang Berada dalam Kawasan Tertentu: Peraturan Menteri Agraria dan Tata Ruang/Kepala Badan Pertanahan Nasional, Nomor 9 Tahun 2015.

KATR/BPN. (2016). Tata Cara Penetapan Hak Komunal atas Tanah Masyarakat Hukum ADAT dan Masyarakat yang Berada pada Kawasan Tertentu: Peraturan Menteri Agraria dan Tata Ruang/Kepala Badan Pertanahan Nasional Nomor 10 Tahun 2016.

Kawharu, M. (2011). Forestry and indigenous issues: New Zealand and the Pacific. Paper presented at the International Expert Group Meeting Indigenous Peoples and Forests, New York.

KEMENDAGRI (2014). Pedoman Pengakuan dan Perlindungan Masyarakat Hukum ADAT: Peraturan Menteri Dalam Negeri Nomor 52 tahun 2014.

KEMENDAGRI, K., PU,BPN ,;. (2014). Tata Cara Penyelesaian Penguasaan Tanah yang Berada di Dalam Kawasan Hutan: Peraturan Bersama Nomor : 79 Tahun 2014, PB.3/Menhut-11/2014, 17/PRT/M/2014, $8 / \mathrm{SKB} / \mathrm{X} / 2014$.

Kementerian Negara Lingkungan Hidup (2014). Pedoman Penentuan Daya Dukung dan Daya Tampung Lingkungan Hidup. Jakarta: Kementerian Negara Lingkungan Hidup Republik Indonesia.

Kementerian PPN/BAPPENAS (2013). Masyarakat ADAT di Indonesia: Menuju Perlindungan Sosial yang Inklusif. Jakarta: Direktorat Perlindungan dan Kesejahteraan Masyarakat, Kementeriaan PPN/Bappenas.

Klenke, K. (2013). Whose ADAT is it? ADAT, Indigeneity and Social Stratification in Toraja. In B. Hauser-Schäublin (Ed.), ADAT and Indigeneity in Indonesia Culture and Entitlements between Heteronomy and Self-Ascription (Vol. 7, pp. 149-166). Göttingen: Göttingen University Press

KLHK. (2015a). Hutan Hak: Peraturan Menteri Lingkungan Hidup dan Kehutanan Nomor P.32/Menlhk-Setjen/2015.

KLHK. (2015b). Penanganan Konflik Tenurial Kawasan Hutan: Menteri Lingkungan Hidup dan Kehutanan Nomor P.84/Menlhk-Setjen/2015.

Kothari, A. (2007). Traditional Knowledge and Sustainable Development. Manitoba, Canada: International Institute for Sustainable Development (IISD).

Kuper, A. (2003). The Return of the Native. Current Anthropology, 44 (3), 389-402.

Larson, A. M., Cronkleton, P. J., \& Pulhin, J. M. (2015). Formalizing Indigenous Commons: The Role of 'Authority' in the Formation of Territories in Nicaragua, Bolivia, and the Philippines. World 
Development, 70(0), 228-238. doi: http://dx.doi.org/10.1016/j.worlddev.2015.02.004

Lesliea, H. M., Basurto, X., Nenadovic, M., Sievanena, L., Kyle C. Cavanaugh, Cota-Nieto, J. J., . . . Aburto-Oropezag, O. (2015). Operationalizing the social-ecological systems framework to assess sustainability. PNAS, 112/19, 5979-5984.

Li, T., xa, \& Murray. (2010). Indigeneity, Capitalism, and the Management of Dispossession. Current Anthropology, 51(3), 385-414. doi: $10.1086 / 651942$

Linggasari, Y. (2015). Tanpa Perda, Hutan ADAT Sulit Dikukuhkan. 10 November 2015. Retrieved 18 August 2017, from https://www.cnnindonesia.com/nasional/20151109203847-2090549/tanpa-perda-hutan-ADAT-sulit-dikukuhkan/

Linggasari, Y. (2016). Pengabaian Hak Masyarakat ADAT Bisa Berujung Separatisme. 24 Januar 2016y. Retrieved 16 August 2017, from https://www.cnnindonesia.com/nasional/20160124195910-20106337/pengabaian-hak-masyarakat-ADAT-bisa-berujungseparatisme/

Lininger, K. (2011). Small-Scale Farming and Shifting Cultivation. In D. Boucher, C. May-Tobin, K. Lininger \& S. Roquemore (Eds.), The Root of The Problem, What's Driving Tropical Deforestation. Cambridge: Union of Concerned Scientist, Citizens and Scientist for Environmental Solutions

Luz, A., Guèze, M., Paneque-Gálvez, J., Pino, J., Macía, M., Orta-Martínez, M., \& Reyes-García, V. (2015). How Does Cultural Change Affect Indigenous Peoples' Hunting Activity? An Empirical Study Among the Tsimane' in the Bolivian Amazon. Conservation and Society, 13(4), 382-394. doi: 10.4103/0972-4923.179879

Mahkamah Konstitusi Republik Indonesia (2013). Pengujian Undang Undang 41 tahun 1999 tentang Kehutanan (20 Mei 2013 ed.): Putusan Mahkamah Konstutisi Republik Indonesia Nomor 35/PUU-X/2012.

Martinez, D. (2010). The Value of Indigenous Ways of Knowing to Western Science and Environmental Sustainability. The Journal of Sustainability Education.

Mazzocchi, F. (2006). Western science and traditional knowledge: Despite their variations, different forms of knowledge can learn from each other. EMBO Reports, 7(5), 463-466. doi: 10.1038/sj.embor.7400693

McGinnis, M. D., \& Ostrom, E. (2014). Social-ecological system framework: initial changes and continuing challenges. Ecology and Society, 19(2). doi: $10.5751 /$ ES-06387-190230

McKenna, M. (2016). Call for Aboriginal identity tests to expose fake Aborigines, The Australian. 
McKinnon, K. (2012). Civilizing the margins: Southeast Asian government policies for the development of minorities by CHRISTOPHER $R$. DUNCAN (Vol. 43).

Penetapan Hutan ADAT Marga Serampas seluas +/- 24 (dua puluh empat) hektar di Desa Rantau Kermas, Kecamatan Jangkat, Kabupaten Merangin, Propinsi Jambi, SK . 6745/MENLHK-PSKL/KUM-1/12/2016 (2016).

Mertz, O. (2009). Trends in shifting cultivation and the REDD mechanism. Current Opinion in Environmental Sustainability, 1(2), 156-160. doi: http://dx.doi.org/10.1016/j.cosust.2009.10.002

Miller, L., \& Nadeau, S. (2016). Perceptions of public land governance from two Canadian provinces: How is the social agenda being met through sustainable forest management? Land Use Policy. doi: https://doi.org/10.1016/j.landusepol.2016.10.041

Moeliono, M., \& Dermawan, A. (2006). The Impacts of Decentralization on Tenure and Livelihoods. In C. Barr, I. A. P. Resosudarmo, A. Dermawan, J. F. McCarthy, M. Moeliono \& B. Setiono (Eds.), Decentralization of forest administration in Indonesia: implications for forest sustainability, economic development and community livelihoods (pp. 108-150). Bogor, Indonesia: Center for International Forestry Research (CIFOR)

Moeliono, M., Limberg, G., Minnigh, P., Mulyana, A., Indriatmoko, Y., Utomo, N. A., . . . Purwanto, E. (2010). Meretas kebuntuan: konsep dan panduan pengembangan zona khusus bagi Taman Nasional di Indonesia. Bogor, Indonesia: Center for International Forestry Research (CIFOR).

Mongabay. (2015). Dari Rakernas AMAN: Mendagri Bicara Soal Percepatan Pengakuan dan Perlindungan Masyarakat ADAT. 20 March 2015. Retrieved 30 March 2018, 2018, from http://www.mongabay.co.id/2015/03/20/dari-rakernas-amanmendagri-bicara-soal-percepatan-pengakuan-dan-perlindunganmasyarakat-ADAT/

Mongabay. (2017). Jokowi grants first-ever indigenous land rights to 9 communities. Mongabay Series: Global Forests, Indonesian Forests, Jokowi Commitments. 4 January 2017. Retrieved 18 September 2017, 2017, from https://news.mongabay.com/2017/01/jokowigrants-first-ever-indigenous-land-rights-to-9-communities/

Mulyoutami, E., Rismawan, R., \& Joshi, L. (2009). Local knowledge and management of simpukng (forest gardens) among the Dayak people in East Kalimantan, Indonesia. Forest Ecology and Management, 257(10), 2054-2061. doi: http://dx.doi.org/10.1016/j.foreco.2009.01.042

Murniati, Padmanaba, M., Basuki, I., \& van der Ploeg, J. (2006). Gunung Lumut biodiversity assessment socio-economic study: how important 
forest and landscape resource for community living in and around Gunung Lumut protection forest? Final report to TROPENBOS. Bogor, Indonesia: Center for International Forestry Research (CIFOR).

Muur, W. v. d. (2015). Will customary land rights destroy Indonesia's last remaining forests? Retrieved 25 April 2015, 2015, from http://leidenlawblog.nl/articles/will-customary-land-rights-destroyindonesias-last-remaining-forests

Myers, R., Intarini, D., Sirait, M. T., \& Maryudi, A. (2017). Claiming the forest: Inclusion and exclusion under Indonesia's "new" policy on cutomary forest. Land Use Policy, 66, 205-213.

Nair, M. S. (2006) Defining Indigeneity Situating Transnational Knowledge. In W. S. Foundation (Series Ed.), World Society Focus Paper Series. New Delhi.

Nick. (2014, 22 December 2017). From safeguards to safeguarding: Engaging indigenous peoples and local communities on REDD+. Mapping Environmental Justice. 17 July 2014. Retrieved 31 December 2017, 2017, from http://www.ejolt.org/2014/07/from-safeguards-tosafeguarding-engaging-indigenous-peoples-and-local-communitieson-redd/

Nugroho, H. Y. S. H., Skidmore, A. K., \& Hussin, Y. A. (2018). Veryfying Indigenous-Based Claims to Forest Rights Using Remote Sensing and Spatial Information. Submitted to Land Use Policy.

Nugroho, H. Y. S. H., van der Veen, A., Skidmore, A. K., \& Hussin, Y. A. (2017). Expansion of traditional land-use and deforestation: a case study of an ADAT forest in the Kandilo Subwatershed, East Kalimantan, Indonesia. Journal of Forestry Research. doi: 10.1007/s11676-017-0449-9

Osakede, K. O., \& Ijimakinwa, S. O. (2015). Traditional institution and the modern dayadministration of nigeria: Issues and prospects. Journal of Research and Development (RnD), Vol. 2, No. 9.

Padi Indonesia (2010). KAWASAN KELOLA HUTAN ADAT DI KABUPATEN PASER, Surat Pernyataan Bersama: Mengukuhkan Kawasan Kelola Hutan ADAT Di Kabupaten Paser. 27 April 2010. Retrieved 16 October 2017, 2017, from https://padiindonesia.wordpress.com/2010/04/27/kawasan-kelolahutan-ADAT-di-kabupaten-paser/

Plieninger, T., Höchtl, F., \& Spek, T. (2006). Traditional land-use and nature conservation in European rural landscapes. Environmental Science \& Policy, 9(4), 317-321. doi: http://dx.doi.org/10.1016/j.envsci.2006.03.001

PSKL. (2016). Tata Cara Verifikasi dan Validasi Hutan ADAT. Jakarta: Direkorat Jenderal Perhutanan Sosial dan Kemitraan Lingkungan

Rai, R. K., Dhakal, A., Khadayat, M. S., \& Ranabhat, S. (2017). Is collaborative forest management in Nepal able to provide benefits to 
distantly located users? Forest Policy and Economics, 83(Supplement C), 156-161. doi: https://doi.org/10.1016/j.forpol.2017.08.004

RAN. (2017). For First Time in History, Indonesian Government Recognizes Indigenous Customary Land Rights; Returns Contested Company Concessions to Local Communities. Press Release. 04 January 2017. Retrieved 18 September 2017, 2017, from https://www.ran.org/for_first_time_in_history_indonesian_governme nt_recognizes_indigenous_customary_land_rights_returns_contested _company_concessions_to_local_communities

Republik Indonesia (1960). Peraturan Dasar Pokok-Pokok Agraria: Undang Undang Nomor 5 Tahun 1960.

Republik Indonesia (1999). Kehutanan: Undang Undang Nomor 41 Tahun 1999

Republik Indonesia (2008). Rencana Tata Ruang Nasional. Jakarta: Peraturan Pemerintah Nomor 26 Tahun 2008

Rhodes, R. A. W. (1996). The New Governance: Governing without Government1. Political Studies, 44(4), 652-667. doi: 10.1111/j.14679248.1996.tb01747.x

Rives, F., Carrière, S. M., Montagne, P., Aubert, S., \& Sibelet, N. (2013). Forest Management Devolution: Gap Between Technicians' Design and Villagers' Practices in Madagascar. Environmental Management, 52(4), 877-893. doi: 10.1007/s00267-013-0138-1

Rodríguez Bolívar, M. P., Navarro Galera, A., \& Alcaide Muñoz, L. (2015). Governance, transparency and accountability: An international comparison. Journal of Policy Modeling, 37(1), 136-174. doi: http://dx.doi.org/10.1016/j.jpolmod.2015.01.010

Royer, S. D., Visser, L. E., Galudra, G., Pradhan, U., \& Noordwijk, M. V. (2015). Self-identification of indigenous people in postindependence Indonesia: a historical analysis in the context of REDD+. International Forestry Review Vol.17(3).

Rye, S. A., \& Kurniawan, N. I. (2017). Claiming indigenous rights through participatory mapping and the making of citizenship. Political Geography, 61(Supplement $\quad$ C), 148-159. doi: https://doi.org/10.1016/j.polgeo.2017.08.008

Safitri, M. A., \& Bosko, R. E. (2002). Indigenous Peoples/Ethnic Minorities and Poverty Reduction Indonesia. Manila, Philippines: Environment and Social Safeguard Division, Regional and Sustainable Development Department, Asian Development Bank.

Samho, B., \& Purwadi, Y. S. (2016). Perubahan Pola Pikir Masyarakat ADAT Dayak di Kabupaten Sanggau terhadap Hutan ADAT Sebagai Akibat Perkebunan Kelapa Sawit (Vol. Perjanjian No: III/LPPM/2016-02/115P). Bandung: Lembaga Penelitian dan Pengabdian kepada Masyarakat, Universitas Parahyangan. 
Sasaoka, M., \& Laumonier, Y. (2012). Suitability of Local Resource Management Practices Based on Supernatural Enforcement Mechanisms in the Local Social-cultural Context. Ecology and Society, 17(4). doi: $10.5751 /$ ES-05124-170406

Sherpa, L. N., \& Sinogba, E. (2016). Sustainable forest management ties indigenous group together against eviction threats. Case study of the ILC Database of Good Practices. Rome, Italy: International Land Coalition.

Siscawati, M., Banjade, M. R., Liswanti, N., Herawati, T., Mwangi, E., Wulandari, C., . . . Silaya, T. (2017) Overview of forest tenure reforms in Indonesia. Vol. Working Paper 223 (pp. 36). Bogor, Indonesia: Centre for International Forestry Research (CIFOR).

Smith, C. Q. (2005) The Roots of Violence and Prospects for Reconciliation, A Case Study of Ethnic Conflict in Central Kalimantan, Indonesia. Vol. Paper No. 23. SOCIAL DEVELOPMENT PAPERS. Conflict Prevention \& Reconstruction (February 2005 ed.). Wahington DC: The World Bank.

Snively, G., \& Corsiglia, J. (2001). Discovering indigenous science: Implications for science education. Science Education, 85(1), 6-34. doi: 10.1002/1098-237X(200101)85:1<6::AID-SCE3>3.0.CO;2-R

Stason, E. B. (1941). "Substantial Evidence" in Administrative Law. University of Pennsylvania Law Review and American Law Register, 89(8), 10261051. doi: $10.2307 / 3309074$

Tessier, J., Shakya, P., Carling, J., \& Wattimena, P. (2016). Indigenous Peoples' Initiatives For Land Rights Recognition In Asia. Chiang Mai: Asia Indigenous Peoples Pact (AIPP) Foundation.

Tinus, O., Murianson, Gunawan, J., Nurhayati, L., \& Diprose, R. (2014). Dukungan Penguatan Kelembagaan Bagi Desa dalam Mengelola Kegiatan REDD+, Sebuah Pembelajaran Lapangan dari Demonstrasi REDD+ di Kabupaten Kapuas, Provinsi Kalimantan Tengah Jakarta: Kalimantan Forests and Climate Partnership, Indonesia-Australia Forest Carbon Partnership.

Tribun bisnis. (2017). Menko Darmin Mengaku Tidak Senang Masyarakat Klaim Punya Hak Atas Tanah ADAT. 26 March 2017. Retrieved 14 October 2017, 2017, from http://www.tribunnews.com/bisnis/2017/03/26/menko-darminmengaku-tidak-senang-masyarakat-klaim-punya-hak-atas-tanahADAT

Tropenbos International Indonesia (2006). Penilaian Ekonomi Sumberdaya Hutan Lindung Gunung Lumut, Kabupaten Paser, Kalimantan Timur (Vol. TE-06/TBI Indonesia/05-I). Bogor, Indonesia: Tropenbos International Indonesia dan Greenomics Indonesia.

Tsing, A. (2002). Indigenous Voice. In M. D. L. Cadena \& O. Starn (Eds.), Indigenous Experience Today (pp. 33-68). Oxford, UK: Berg, Oxford International Publishers 
Tyson, A. D. (2010). Decentralization and ADAT revivalism in Indonesia: The politics of becoming indigenous.

UN. (2009). State of the World's Indigenous Peoples (Vol. ST/ESA/328). New York: Secretariat of the Permanent Forum on Indigenous Issues, Division for Social Policy and Development, Department of Economic and Social Affairs, The UN.

UNEP. (2011). Emerging Perspectives on Forest Biodiversity UNEP Year Book 2011: United Nations Environment Programme

UNEP. (2012). Deforestation Costing Kenyan Economy Millions of Dollars Each Year and Increasing Water Shortage Risk. 5 November 2012. Retrieved 13 May, 2013, from http://www.unep.org/Documents.Multilingual/Default.asp?DocumentI $D=2698 \&$ ArticleID $=9316 \& \mathrm{I}=\mathrm{en}$

UNHR. (2013) Indigenous Peoples and the United Nations Human Rights System. Vol. Fact Sheet No. 9/Rev.2. New York and Geneva: United Nations Human Rights, Office of The High Commisioner.

United Nations (2008). United Nations Declaration on the Rights of Indigenous Peoples: United Nations.

UNPO. (2014). West Papua: Indonesian Transmigration Program Further Marginalizes the Indigenous Population. 6 November 2015. Retrieved 3 October 2017, 2017, from http://unpo.org/article/17676

Varagur, K. (2017). Indigenous Indonesians Still Waiting for Promised Forest Land. Asia. 21 March 2017. Retrieved 18 September 2017, 2017, from https://www.voanews.com/a/indonesia-indigenous-forest-landreturn/3775469.html

Wachira, G. M. (2010). Applying Indigenous Peoples' Customary Law in Order to Protect their Land Rights in Africa. In G. Rose \& J. Dahl (Eds.), Development and Customary Law (pp. 6-15). Copenhagen, Denmark: International Work Group for Indigenous Affairs

Wahyuni, T. (2011). Can traditional forest management protect and conserve ironwood (ulin) stands? An option and approach in East Kalimantan. (Doctor), University of Leiden, Leiden, The Netherlands.

Wijaya, T. (2014). Tokoh ADAT Disidangkan, NGO akan Gugat Perusahaan Perambah SM Dangku. September 24, 2014 from http://www.mongabay.co.id/2014/09/24/tokoh-ADAT-disidangkanngo-akan-gugat-perusahaan-perambah-sm-dangku/

Wulan, Y. C., Yasmi, Y., Purba, C., \& Wollenberg, E. (2004). Analisa Konflik Sektor Kehutanan di Indonesia 1997-2003. Bogor: CIFOR.

Yunitasari. (2009). Pengembangan Kapasitas Kelembagaan Masyarakat ADAT dalam Merespon Program Pemberdayaan. (Magister Profesional Tesis), Institut Pertanian Bogor, Bogor.

Zakaria, Y. (2017, 10 February 2017). After the customary forest recognition. 26 January 2017. Retrieved 10 February 2017, 2017, from 
http://www.thejakartapost.com/academia/2017/01/26/after-thecustomary-forest-recognition.html 
CHAPTER 6

SYNTHESIS 


\subsection{Introduction}

Limited transparency, accountability, and participation in policy formulation as well as implementation, all lead to failure to attain sustainable forest management (SFM). Along with the reluctance of policy makers, the often limited stakeholder capacity and the lack of accurate data bases have also proved to be constraints in the development of appropriate action. The issues have been more complicated where they were correlated with economic imperatives, vested interest, ownership issues and the basic rights of indigenous communities living inside or adjacent the forest. Indigenous peoples, forest communities, scientist, and supportive environmental, human rights and social non-governmental organizations as well as governments agreed that forest and environment-based conflict and destruction will not be ending without securing indigenous peoples' land and territorial rights (Chino \& DeBruyn, 2006; Escott et al., 2015; FPP et al., 2014; Human Rights Equal Opportunity Commission 2005; Linggasari, 2016; The Secretariat of the UN Permanent Forum on Indigenous Issues 2005; UNESCO, 2017; UNPO, 2014).

In Indonesia, a country with more than 1,300 ethnic groups and more than 2,500 languages (BPS, 2010), issues related to indigenous people and customary right have been considered as intriguing issues for many years and widely increased since the regional autonomy era (Banjade et al., 2016; Royer et al., 2015). The issue has been more prominent after the Indonesian Constitutional Court on May 2013 ruled the decision No. 35 of 2012 (MK 35) which restores the rights of ADAT (indigenous) people to own and manage their territory by annulling the state's ownership to the ADAT forest. The handover of this right is a radical step of engaging with ADAT people in Indonesian forest management.

However, several questions emerged: who really deserve to hold the rights, do they have sufficient capacity and committment to manage the forest, will the forest be managed better than before the rights are transferred, and how to maintain the established commitments.

In fact, the process of decentralization of forest management in many countries have failed to engage indigenous peoples and local communities in a meaningful way (Gooda, 2010; Nick, 2014), due to lack of transparency and an overly technocratic approach (Gautier et al., 2015; Nick, 2014), lack of consideration of local knowledge (Gautier et al., 2015), and remains fraught with administrative inefficiencies and a mistrust of local communities (Gautier et al., 2015; Gbedomon et al., 2016; Miller \& Nadeau, 2016). On the other side, the widely accepted premise of indigenous people, a selfsustaining community with a strong connection to the forest linked by norms, beliefs and traditions (Arizona \& Cahyadi, 2013; Li et al., 2010; Mulyoutami 
et al., 2009; Sasaoka \& Laumonier, 2012; Wachira, 2010), are questioned not the least from anthropologist (Kuper, 2003). Claims in the international policy discourse that community managed forests are better than state managed forests may be true, but are rarely supported by evidence (Boedhihartono, 2017).

Engagement in forest governance connotes a relatively sustained and systematic interaction (Holmes, 2011). In the context of engaging with ADAT people, this interaction is intended to build trust and relationship between government and ADAT people. Government, civil society and ADAT community realized that the recognition of rights over forest of ADAT people is a basic prerequisite to promote equitable and sustainable forest governance and management reforms. Systematic solutions to engage with ADAT people are essential if sustainable forest management is to be achieved, considering the appropriate institution, mechanism and tools to design and implement the strategy of sustainable forest management.

The general objective of this research is to generate appropriate mechanism to engage with ADAT people in SFM. The specific objectives of this research are to: 1) developing a concept for the reform of forest-based spatial planning respecting the basic rights of the ADAT people, covering policy making as well as a way to introduce policy reform, 2) generating a better understanding of deforestation in correlation with traditional land-use expansion and promoting measures to develop more productive traditional land-use systems while decreasing deforestation, 3) examining substantial evidences to improve verification mechanism of recognition of ADAT rights over forest area and 4) examining appropriate measures in engaging with ADAT people.

In order to achieve these objectives, a series of literature studies and field research activities from the development of concept for the reform of forestbased spatial planning respecting the basic rights of the ADAT people to the integration of spatial analysis, field measurement and socio-economic observations of ADAT people and their activities were undertaken.

Details of the research activities have been presented in the chapters 2 to 5 . In this chapter, the research findings and their application as well as their benefits to society and management are synthesized.

\subsection{Adaptive forest governance}

Empirical data across countries show that a main cause of forest destruction and conflict among stakeholders is weak governance, which is characterized by limited transparency, accountability, and participation (Carothers \& Brechenmacher, 2014; Drazkiewicz et al., 2015; Rodríguez Bolívar et al., 
2015). The term governance is used to label a process marking a decreasing role for the government and an increasing role for others in public service provision, addressing social as well as economic considerations at the same times in a balanced way (Rhodes, 1996).

Failure of the previous classical spatial planning governance is caused by the dominance of an interest group indifferent to open policy alternatives. The governance process needs to assure that there will be an equal opportunity for all stakeholders to benefit from the process. Thus, for agreement in governing, future interaction among stakeholders is a necessity.

The Spatial Planning Law 26 (2007) and the Government Regulation of National Spatial Plan 26 (2008), stipulated that the ADAT community has a legal position to affect spatial planning policy particularly the spatial policy of the forest. However, involving the ADAT community in spatial planning process is not an easy process. ADAT rights normatively are acknowledged but in practice they are not properly accommodated in land use planning processes. The recognition of usufruct right of indigenous people, -the right to derived benefits from the forest and forest land without any damage on the forest function- as stated in forestry-related statutes has not yet been translated in practical regulation (Kusumanto, 2007; Nizar, 2010; Raharjo, 2014). Meanwhile, as community groups with a large population depending on forest resources, ADAT communities are at an increased threat from landuse change impact, global deforestation and environment degradation.

We recommend two interrelated factors as a prerequisite of good quality forest-based spatial planning for achieving sustainable forest management considering ADAT rights : 1) Availability of an appropriate institution to formulate forest-based spatial planning law based on various resource, needs, and knowledge of multi stakeholders and 2) Availability of appropriate mechanisms and tools to formulate sustainable forest management technologies based on comprehensive and accurate data and information.

The important factors of good forest-based spatial planning are the availability of appropriate institutions, the availability of holistic and accurate data and information and availability of appropriate mechanisms and tools to formulate adaptive management technologies. For Indonesia, as a quite young democratic country, the challenges are accessibility and availability of data/information, low quality of stakeholders' capacity, and political resistance. For almost all local governments, data and information are rather scarce and expensive.

By employing appropriate mechanism and tools in formulating SFM policy, the need to secure basic ADAT rights in balance with the need to attain 
sustainable forest management can be accommodated and tested transparently and scientifically. Using spatial modeling, the correlation between actual conditions, policy formulation process, formulated policies, and potential impact after implementation can be traced. The most suitable land for ADAT people and the best management practice for traditional landuse, (technically applicable, economically feasible, socially acceptable, and ecologically suitable) with efficient input, high yield, and low negative impact on the forest landscape can thus be determined and designed.

The capacity of stakeholders involved in the process is seen here as a critical issue. Thus, building capacity and raising willingness of stakeholders responsible for policy formulation, interpretation, and implementation are essential (Nugroho et al., 2017). Related to the effort to increase local people participation, a transparent policy process is thus a key factor. People will only participate when there is trust. It is impossible to gain the trust of citizens without providing transparent factual information (Grimmelikhuijsen, 2012; Hasan, 2013). Transparency will not only increase efficiency in resource allocation, but will also make an equitable distribution of benefits possible (Bellver \& Kaufmann, 2005; The Union for Ethical BioTrade 2013).

Another fundamental prerequisite for adaptive governance and management is the learning capability and willingness of stakeholders to move out of their 'comfort zone'. Two problems that will be encountered are defensiveness and the ego of actors (Nugroho et al., 2017). Defensive attitudes resulting from defensive reasoning will block any real change. Learning therefore not only contains a technical aspect but also a moral-behavioral one. Kolb (1984) promotes experiential learning, where he considers experience as a source of learning. Learning is the continuous process of human adaptation to create knowledge as a transformation of experiences. To motivate local communities and to promote a dedicated approach to landscape management, a participatory learning approach (PLA) as an effort to involve communities in formulating and evaluating a problem and its solutions (Bottomley \& Denny, 2011), should be employed.

We recommend that national policymakers allow flexibility in spatial planning policy implementation but develop mechanisms of accountability and control between local and central authorities. The quality of decision making can be improved if decision makers are aware of the implications of their actions. The process of collecting and analyzing data for a basis of decision making must be conducted systematically and precisely. The quality of information reflects the accountability as a base for legitimacy. Again, the supporting effort to make all systems work is increasing the capacity and willingness of all actors responsible in policy formulation, interpretation, and implementation. 


\subsection{Image interpretation, spatial modelling and sociocultural survey: mixed methods to analyze existing and future pattern of traditional landuse and deforestation and how to response}

Recent evidence shows that in areas with a high rate of deforestation, commercial farmers are the main agents of deforestation (Adams et al., 2013; Lininger, 2011; Mertz, 2009; Rudel et al., 2009; Seidenberg et al., 2003). In areas with low deforestation rates, however, small farmers and subsistence shifting cultivation are seen as the major contributors (Damnyag et al., 2013; Geist \& Lambin, 2002; Lininger, 2011; Rudel et al., 2010; Shearman et al., 2009). The potential pressure of small farms on forests is high due to the millions of people who rely on agriculture for their livelihoods, dwelling in or near forest areas. In Indonesia, approximately 25,800 villages (36.7\% of all villages in Indonesia) are inside or adjacent to forest areas. Of these, $98 \%$ rely on agriculture for their livelihoods (Badan Planologi Kehutanan 2007; Direktorat Jenderal Planologi Kehutanan 2009).

Previous studies from many countries show how improved productivity and policy interventions concerning land rights security have positive impacts on food security and deterring deforestation (Angelsen \& Kaimowitz, 2001; Araujo et al., 2010; Branca et al., 2011; Chi et al., 2013; Epule et al., 2014; Fearnside, 2001; Tachibana et al., 2001; Tomich et al., 2001). However, there are still knowledge gaps, especially in the relationships between and among the biophysical, economic development, sociocultural aspects, and effective policy responses (Carr, 2008; Chomitz et al., 2007; Damnyag et al., 2013; Mattsson et al., 2012; Pasgaard, 2013; Pouliot et al., 2012). Moreover, most studies of deforestation drivers have been based on macro level regional or national data, thus presenting difficulties in addressing the complexity of local situations (Bottazzi \& Dao, 2013).

To understand thoroughly existing and future trends of the spatial patterns of the expansion of traditional land-use and deforestation, mixed methods with image interpretation, spatial modeling and sociocultural surveys were employed to examine the interrelationships between physical conditions, community characteristics and traditional land-use expansion. Instead of developing approaches to stop deforestation, this examination explored spatial analytical approaches to provide a better understanding of deforestation in correlation with agricultural expansion. By using an area production model (APM), we were able to analyze the effect of improved farming systems, policy intervention and law enforcement on traditional landuse expansion and deforestation. 
Our spatial analysis of traditional land-use expansion and deforestation indicated that slope and accessibility are important factors affecting traditional land-use expansion. The steeper the slope and the farther the distance, the lower the rate of deforestation. However, due to the dynamics of human behaviour, some areas of traditional land-use are randomly located, inconsistent with these factors.

Our spatial analysis of three villages shows differences between sociocultural characteristics, experience, and farming practices. The lowest rate of deforestation per capita occurred where customary laws strictly regulate people's activities. Meanwhile, in the more modern communities, deforestation was higher as a consequence of higher financial capital as well as knowledge and experience.

The essential measures, however, are empowerment of customary law and adaptation of indigenous knowledge in forest management to meet current needs and conditions. Long-term security and short-term consumption of agricultural commodities should be optimized through the combination of land management and local institutional enforcement. Land-use management that enhances farming income while avoiding deforestation and degradation must be promoted, supported by land allocation and implementation of formal laws that respect ADAT law and revitalize ADAT institutions.

At least, there are three factors important in order to decrease deforestation and increase community welfare: (1) increasing land productivity by improving farming practices, (2) land allocation to ensure livelihood security, and (3) law enforcement synergizing formal law and ADAT law to ensure implementation of sustainable land-use management. A combination of the three approaches will result in an increase in crop productivity, sufficient for households to have a minimum standard of living with less deforestation.

\subsection{Substantial evidence of indigeneity: "de facto" recognition}

The new history of ADAT rights recognition in Indonesia was started on 16 May, 2013, when the Indonesian Constitutional Court issued a decision No. 35/PUU-X/2012 on the Judicial Review of Law Number 411999 on Forestry (MK 35) delivered by indigenous peoples alliances. The MK 35, an important step forward for ADAT forest users (Myers et al., 2017), invalidated provisions regarding the customary forest in Forestry Law. The Constitutional Court confirmed that ADAT forests located in indigenous territories should no longer be considered as State Forests (Mahkamah Konstitusi Republik Indonesia 2013). However, in implementation level, special measures are required. It remains difficult to prove who is indigenous and who is not. There 
have been indications of people asserting for indigeneity to claim rights over land for short term economic and political benefits.

Using case study, we develop an approach in verification process of "de facto" recognition of ADAT rights over forests by assessing the evidence to support the existing legal framework. Evidence was analyzed to examine the capacity, capabilities and awareness of indigenous peoples to manage their territory sustainably using a combination of two methods: 1) analysis of map conformity as instrument of traditional knowledge assessment, and 2) analysis of historical land-use pattern as an instrument of ADAT law implementation assessment.

This approach was designed to ensure that the transfer of control rights over forest to certain group of people is not merely as a form of rights recognition, political persuasion, but also an attempt to ensure that the ADAT forest will remains sustainably for the benefit of ADAT community and the environment. Using special measures in analysing the evidence, we were able to depict the de facto condition of ADAT people. Ancestral norms, beliefs and traditional wisdoms in general are owned and applied by ADAT people living around the GLPF. Nonetheless, increasing the necessities of life, better accessibility, and socio-culture assimilation changed the behavior towards nature of the ADAT people. Notwithstanding the social importance of customary land rights, our findings indicate that the critique of environmentalists regarding ADAT people might be justified. When even remote people are forced by the necessities of life to convert ancestral forest into a rubber and oil palm plantation to survive, how can the 'self-sustaining community with strong connection with nature' discourse be upheld any longer? Everyday needs have shifted a lot. Daily needs are no longer just a necessity of food and clothing but have increased, among others, with the need for education, access to information and other secondary goods such as motor vehicles to access their farming areas.

Long term engagement with ADAT people must be planned and implemented systematically to attain sustainable benefits of ADAT forest management. Formal law enforcement and revitalization of ADAT law are essential measures to be conducted in line with efforts to enhance the community welfare.

\subsection{Engaging with ADAT people}

The social pillar of SFM is broad, encompassing concepts such as participation, fairness, access and use rights, safety, gender equity, and the management of change and conflict in communities affected by forest activities. These aspects need appropriate attention in any effort to 
implement SFM (FAO, 2014). When correspond with indigenous people living in the forest area, the efforts will be much more complicated. The widely accepted positive stigma of indigenous people, as a self-sustaining community with a strong connection to the forest linked by norms, beliefs, and traditions have been questioned as many scientists begin to doubt its validity (Grumblies, 2013; Kuper, 2003; Muur, 2015). Political persuasion tendency (Kuper, 2003), impure indigeneity claim (Badan Legislasi 2017; Chavers, 2014; Kuper, 2003; Linggasari, 2016; McKenna, 2016; Moeliono et al., 2010; Tribun bisnis, 2017), indigeneity politics (Tyson, 2010), pragmatism and indigeneity abrasion, change of behavior towards nature due to increase of need of cash (Anthias, 2017; Huntington et al., 2004; Kothari, 2007; Luz et al., 2015; Muur, 2015), are among reasons of the need of better attention and measurable measures in granting the right over forest.

The handover of right over forest from state to ADAT community following the Indonesian constitutional court decision number 35 of 2013 is a radical form of government effort in engaging with ADAT peoples in forest management. However, a partial or merely legal formal approach will not work to foster long term engagement. Effective engagement underpins a commitment to re-arranging the relationships between government and ADAT people involving capacity and trust building and promoting dialogue. In the first steps, there must be substantial evidence, logic and reasonable evidences resulted from adequate and well-controlled investigation, instead of merely based on legal formal evidences as a basis of handover of rights over forest.

Engaging with people who legally and substantially deserved to manage ADAT forest is the basic condition to achieve the goals of SFM and avoid longterm conflicts in the future. A partial or sectoral formality approach with limited participation of ADAT people as well as "non-indigenous" people, will not work to foster long terms engagement. There must be substantial evidence, logic and reason resulting from adequate and well-controlled investigations, instead of on formality evidence as presented through legal processes, before the rights of control over land is transferred to the targeted people. The main concerns to be addressed include: 1) detailed verification of two aspects of the representativeness prerequisite of indigenous people: status legitimation and the capacity of the indigenous people, 2) anticipation of potential conflict as excesses of the strict use of indigenous people terms and the unilaterally claim of territory, and 3) supervision, assistance, building of institutional, technical, and financial capacity of ADAT people to manage and utilize their ADAT forest sustainably and promoting continuous dialogs to maintain the established commitments. 


\subsection{General conclusion}

The general objective of the research is to generate appropriate mechanism to engage with ADAT people in SFM. The social pillar of SFM is broad, encompassing concepts such as participation, fairness, access and use rights, safety, gender equity, and the management of change and conflict in communities affected by forest activities.

Based on our study, there are two interrelated factors as a prerequisite of good quality forest-based spatial planning for achieving sustainable forest management considering ADAT rights : 1) Availability of an appropriate institution to formulate forest-based spatial planning law based on various resource, needs, and knowledge of multi stakeholders, and 2) Availability of appropriate mechanisms and tools to formulate sustainable forest management technologies based on comprehensive and accurate data and information. By employing appropriate mechanism and tools in formulating SFM policy, the need to secure basic ADAT rights in balance with the need to attain sustainable forest management can be accommodated and tested transparently and scientifically. Our study proved that the use of mixed methods, a combination of image interpretation, spatial analysis, modeling, and thorough analysis of socio-economic and culture of how ADAT people manage their land, was able to develop better justification as a basis of policy development.

We believe that the recognition of forest rights for ADAT peoples is a basic prerequisite to promote equitable and sustainable forest governance and management reforms. Systematic solutions to engage with ADAT people are essential if sustainable forest management is to be achieved, considering the appropriate institution, mechanism and tools to design and implement the strategy of sustainable forest management. The use of a scientific approach to determine who to be engage and how the forest should be managed becomes a must to ensure accountability of the policies taken.

We have developed an approach in verification process of "de facto" recognition of ADAT rights over forest by assessing substantial evidences to support the existing legal formal evidence. This approach was designed to ensure that the transfer of control rights over forest to certain group of people is not merely as a form of rights recognition, political persuasion, but also an attempt to ensure that the ADAT forest will remains sustainably for the benefit of ADAT community and the environment.

Long term engagement with ADAT people must be planned and implemented systematically to attain sustainable benefits of ADAT forest management. Formal law enforcement and revitalization of ADAT law are essential 
measures to be conducted in line with efforts to enhance the community welfare. Good engagement underpins a commitment to re-arranging the relationships between government and ADAT people involving capacity and trust building and promoting dialogue. In the early step, there must be substantial evidence, logic and reasonable evidences resulted from adequate and well-controlled investigation, instead of merely based on legal formal evidences as a basis of handover of rights over forest.

Again, the supporting effort to make all systems work is increasing the capacity and willingness of all actors responsible in policy formulation, interpretation, and implementation. We suggest that various parties, especially the government and ADAT people, should take an active role in developing collective actions to ensure that the ADAT forest will be managed sustainably: capacity (institutional, technical and financial) building, trust building and promoting dialogue. The right of permanent sovereignty over natural resources should be an instrument of the alleviation of poverty, physical and cultural survival, and ADAT law-based social and economic development. ADAT law must be revitalized and empowered in accordance with formal state regulation enforcement.

\section{References}

Adams, C., Chamlian Munari, L., Vliet, N., Sereni Murrieta, R., Piperata, B., Futemma, C., . . . Spressola-Prado, V. (2013). Diversifying Incomes and Losing Landscape Complexity in Quilombola Shifting Cultivation Communities of the Atlantic Rainforest (Brazil). Human Ecology, 41(1), 119-137. doi: 10.1007/s10745-012-9529-9

Angelsen, A., \& Kaimowitz, D. (2001). Agricultural technology and forests: a recapitulation Agricultural technologies and tropical deforestation (pp. 383-402). Wallingford, Oxon, UK: CABI Publishing

Anthias, P. (2017). Ch'ixi landscapes: Indigeneity and capitalism in the Bolivian Chaco. Geoforum, 82(Supplement C), 268-275. doi: https://doi.org/10.1016/j.geoforum.2016.09.013

Araujo, C., Bonjean, C. A., Combes, J.-L., Motel, P. C., \& Reis, E. J. (2010). Does Land Tenure Insecurity Drive Deforestation in the Brazilian Amazon? CERDI, Etudes et Documents (Vol. E 2010.13): CERDI.

Arizona, Y., \& Cahyadi, E. (2013). The Revival of Indigenous Peoples: Contestations over a Special Legislation on Masyarakat ADAT. In B. Hauser-Schäublin (Ed.), ADAT and Indigeneity in Indonesia Culture and Entitlements between Heteronomy and Self-Ascription (Vol. 7, pp. 43-62). Göttingen: Göttingen University Press

Badan Legislasi (2017). Mempolitisir Masyarakat ADAT Merusak Tatanan. 13 September 2017. Retrieved 14 October 2017, 2017, from 
http://www.dpr.go.id/berita/detail/id/17628/t/Mempolitisir+Masyarak at+ADAT+Merusak+Tatanan

Badan Planologi Kehutanan (2007). Identifikasi Desa Dalam Kawasan Hutan 2007. Jakarta: Kerjasama Pusat Rencana dan Statistik Kehutanan, Departemen Kehutanan dengan Direktorat Statistik Pertanian, Badan Pusat Statistik.

Banjade, M. R., Herawati, T., Liswanti, N., \& Mwangi, E. (2016) Tenure reform in Indonesia, When? What? Why?, iNFO bRIEF: Vol. 163 (December 2016 ed.). Bogor: CIFOR.

Bellver, A., \& Kaufmann, D. (2005). 'Transparenting Transparency' Initial Empirics and Policy Applications. Paper presented at the IMF conference on transparency and integrity.

Boedhihartono, A. K. (2017). Can Community Forests Be Compatible With Biodiversity Conservation in Indonesia? Land 6, 21, 17. doi: 10.3390/land6010021

Bottazzi, P., \& Dao, H. (2013). On the road through the Bolivian Amazon: A multi-level land governance analysis of deforestation. Land Use Policy, 30(1), 137-146. doi: http://dx.doi.org/10.1016/j.landusepol.2012.03.010

Bottomley, S., \& Denny, P. (2011). A participatory learning approach to biochemistry using student authored and evaluated multiple-choice questions. Biochemistry and Molecular Biology Education, 39(5), 352361. doi: 10.1002/bmb.20526

BPS. (2010). Kewarganegaraan, Suku Bangsa, Agama, dan Bahasa Seharihari Penduduk Indonesia, Hasil Sensus Penduduk 2010. Jakarta: Subdirektorat Statistik Demografi, Badan Pusat Statistik.

Branca, G., McCarthy, N., Lipper, L., \& Jolejole, M. C. (2011). Climate-Smart Agriculture: A Synthesis of Empirical Evidence of Food Security and Mitigation Benefits from Improved Cropland Management Mitigation of Climate Change in Agriculture Series 3. Rome, Italy: Food and Agriculture Organization of the United Nations.

Carothers, T., \& Brechenmacher, S. (2014). Accountability, transparency, participation, and inclusion, a new development consensus? Washington DC: Carnegie Endowment for International Peace.

Carr, D. (2008). Farm Households and Land Use in a Core Conservation Zone of the Maya Biosphere Reserve, Guatemala. Human Ecology, 36(2), 231-248. doi: 10.1007/s10745-007-9154-1

Chavers, D. (2014). 5 Fake Indians: Checking a Box Doesn't Make You Native, Census data about Native Americans is often misleading. October 15, 2014. Retrieved 14 October 2017, 2017, from https://indiancountrymedianetwork.com/history/events/5-fakeindians-checking-a-box-doesnt-make-you-native/

Chi, V., Rompaey, A., Govers, G., Vanacker, V., Schmook, B., \& Hieu, N. (2013). Land Transitions in Northwest Vietnam: An Integrated 
Analysis of Biophysical and Socio-Cultural Factors. Human Ecology, 41(1), 37-50. doi: 10.1007/s10745-013-9569-9

Chino, M., \& DeBruyn, L. (2006). Building True Capacity: Indigenous Models for Indigenous Communities. American Journal of Public Health, 96(4), 596-599. doi: 10.2105/ajph.2004.053801

Chomitz, K. M., Piet Buys, Giacomo De Luca, Thomas, T. S., \& WertzKanounnikoff, S. (2007). At Loggerheads? Agricultural Expansion, Poverty Reduction, and Environment in the Tropical Forests $A$ World Bank Policy Research Report. Washington, DC: The World Bank.

Damnyag, L., Saastamoinen, O., Blay, D., Dwomoh, F. K., Anglaaere, L. C. N., \& Pappinen, A. (2013). Sustaining protected areas: Identifying and controlling deforestation and forest degradation drivers in the Ankasa Conservation Area, Ghana. Biological Conservation, 165(0), 86-94. doi: http://dx.doi.org/10.1016/j.biocon.2013.05.024

Direktorat Jenderal Planologi Kehutanan (2009). Identifikasi Desa Dalam Kawasan Hutan 2009. Jakarta: Kerjasama Departemen Kehutanan dengan Badan Pusat Statistik.

Drazkiewicz, A., Challies, E., \& Newig, J. (2015). Public participation and local environmental planning: Testing factors influencing decision quality and implementation in four case studies from Germany. Land Use Policy, 46, 211-222. doi: http://dx.doi.org/10.1016/j.landusepol.2015.02.010

Epule, E. T., Peng, C., Lepage, L., \& Chen, Z. (2014). Policy options towards deforestation reduction in Cameroon: An analysis based on a systematic approach. Land Use Policy, 36(0), 405-415. doi: http://dx.doi.org/10.1016/j.landusepol.2013.09.004

Escott, H., Beavis, S., \& Reeves, A. (2015). Incentives and constraints to Indigenous engagement in water management. Land Use Policy, 49(Supplement C), 382-393. doi: https://doi.org/10.1016/j.landusepol.2015.08.003

FAO. (2014). SFM for social development. Natural Forets Management. June 22, 2014. Retrieved 9/10/2017, 2017, from http://www.fao.org/forestry/sfm/85287/en/

Fearnside, P. M. (2001). Land-Tenure Issues as Factors in Environmental Destruction in Brazilian Amazonia: The Case of Southern Pará. World Development, 29(8), 1361-1372. doi: http://dx.doi.org/10.1016/S0305-750X(01)00039-0

FPP, Pusaka, \& Pokker SHK (2014). Securing Forests Securing Rights, Report of the International Workshop on Deforestation and the Rights of Forest Peoples. Palangkaraya: Forest People Programme, Pusaka, and Kelompok Kerja Sistem Hutan Kerakyatan.

Gautier, D., Garcia, C., Negi, S., \& Wardell, D. A. (2015). The limits and failures of existing forest governance standards in semi-arid contexts. International Forestry Review, 17(S2), 114-126. 
Gbedomon, R. C., Floquet, A., Mongbo, R., Salako, V. K., Fandohan, A. B., Assogbadjo, A. E., \& Glèlè Kakaï, R. (2016). Socio-economic and ecological outcomes of community based forest management: A case study from Tobé-Kpobidon forest in Benin, Western Africa. Forest Policy and Economics, 64(Supplement C), 46-55. doi: https://doi.org/10.1016/j.forpol.2016.01.001

Geist, H. J., \& Lambin, E. F. (2002). Proximate Causes and Underlying Driving Forces of Tropical Deforestation: Tropical forests are disappearing as the result of many pressures, both local and regional, acting in various combinations in different geographical locations. BioScience, 52(2), 143-150. doi: 10.1641/00063568(2002)052[0143:pcaudf]2.0.co;2

Gooda, M. (2010). Social Justice and Aboriginal and Torres Strait Islander peoples access to services. Paper presented at the QCOSS Regional Conference: Building a Better Future-themed around improving service delivery for regional and remote communities. https://www.humanrights.gov.au/news/speeches/social-justice-andaboriginal-and-torres-strait-islander-peoples-access-services-2010

Grimmelikhuijsen, S. (2012). Linking transparency, knowledge and citizen trust in government: an experiment. International Review of Administrative Sciences, 78(1), 50-73. doi: 10.1177/0020852311429667

Grumblies, A.-T. (2013). Being Wana, Becoming an "Indigenous People". Experimenting with Indigeneity in Central Sulawesi. In B. HauserSchäublin (Ed.), ADAT and Indigeneity in Indonesia Culture and Entitlements between Heteronomy and Self-Ascription (Vol. 7, pp. 82-98). Göttingen: Göttingen University Press

Hasan, H. A. (2013). Transparency, Trust and Confidence in the Public Sector. British Journal of Arts and Social Sciences, Vol.13 No.I.

Holmes, B. (2011) Citizens' engagement in policymaking and the design of public services. Vol. Research Paper No. 1, 2011-12 (22 July 2011 ed.). Canberra, Australia: Department of Parliamentary Services.

Human Rights Equal Opportunity Commission (2005). Guidelines for engagement with indigenous peoples. Paper presented at the United Nations Workshop - International Conference on Engaging Communities - Brisbane, Australia, Brisbane, Australia.

Huntington, H., Callaghan, T., Fox, S., \& Krupnik, I. (2004). Matching traditional and scientific observations to detect environmental change : A discussion on Arctic terrestrial ecosystems. Ambio(13), 18-23.

Kolb, D. A. (1984). The Process of Experiential Learning Experiential learning: experience as the source of learning and development. Englewood Cliffs, New Jersey Prentice Hall 
Kothari, A. (2007). Traditional Knowledge and Sustainable Development. Manitoba, Canada: International Institute for Sustainable Development (IISD).

Kuper, A. (2003). The Return of the Native. Current Anthropology, 44 (3), 389-402.

Kusumanto, T. (2007). Shaping Opportunities for Improving Forest Quality and Community Livelihoods in Central Sumatra and East Kalimantan, Indonesia. In R. Fisher, R. Prabhu \& C. McDougall (Eds.), Adaptive Collaborative Management of Community Forests in Asia Experiences from Nepal, Indonesia and the Philippines (pp. 93-133). Bogor, Indonesia: Center for International Forestry Research

Li, T., xa, \& Murray. (2010). Indigeneity, Capitalism, and the Management of Dispossession. Current Anthropology, 51(3), 385-414. doi: $10.1086 / 651942$

Linggasari, Y. (2016). Pengabaian Hak Masyarakat ADAT Bisa Berujung Separatisme. 24 Januar 2016y. Retrieved 16 August 2017, from https://www.cnnindonesia.com/nasional/20160124195910-20-

106337/pengabaian-hak-masyarakat-ADAT-bisa-berujungseparatisme/

Lininger, K. (2011). Small-Scale Farming and Shifting Cultivation. In D. Boucher, P. Elias, K. Lininger, C. May-Tobin, S. Roquemore \& E. Saxon (Eds.), The Root of The Problem What's Driving Tropical Deforestation Today? (pp. 89-94). Cambridge: Union of Concerned Scientists

Luz, A., Guèze, M., Paneque-Gálvez, J., Pino, J., Macía, M., Orta-Martínez, M., \& Reyes-García, V. (2015). How Does Cultural Change Affect Indigenous Peoples' Hunting Activity? An Empirical Study Among the Tsimane' in the Bolivian Amazon. Conservation and Society, 13(4), 382-394. doi: 10.4103/0972-4923.179879

Mahkamah Konstitusi Republik Indonesia (2013). Pengujian Undang Undang 41 tahun 1999 tentang Kehutanan (20 Mei 2013 ed.): Putusan Mahkamah Konstutisi Republik Indonesia Nomor 35/PUU-X/2012.

Mattsson, E., Persson, U. M., Ostwald, M., \& Nissanka, S. P. (2012). REDD+ readiness implications for Sri Lanka in terms of reducing deforestation. Journal of Environmental Management, 100(0), 29-40. doi: http://dx.doi.org/10.1016/j.jenvman.2012.01.018

McKenna, M. (2016). Call for Aboriginal identity tests to expose fake Aborigines, The Australian.

Mertz, O. (2009). Trends in shifting cultivation and the REDD mechanism. Current Opinion in Environmental Sustainability, 1(2), 156-160. doi: http://dx.doi.org/10.1016/j.cosust.2009.10.002

Miller, L., \& Nadeau, S. (2016). Perceptions of public land governance from two Canadian provinces: How is the social agenda being met through 
sustainable forest management? Land Use Policy. doi: https://doi.org/10.1016/j.landusepol.2016.10.041

Moeliono, M., Limberg, G., Minnigh, P., Mulyana, A., Indriatmoko, Y., Utomo, N. A., . . . Purwanto, E. (2010). Meretas kebuntuan: konsep dan panduan pengembangan zona khusus bagi Taman Nasional di Indonesia. Bogor, Indonesia: Center for International Forestry Research (CIFOR).

Mulyoutami, E., Rismawan, R., \& Joshi, L. (2009). Local knowledge and management of simpukng (forest gardens) among the Dayak people in East Kalimantan, Indonesia. Forest Ecology and Management, 257(10), 2054-2061. doi: http://dx.doi.org/10.1016/j.foreco.2009.01.042

Muur, W. v. d. (2015). Will customary land rights destroy Indonesia's last remaining forests? Retrieved 25 April 2015, 2015, from http://leidenlawblog.nl/articles/will-customary-land-rights-destroyindonesias-last-remaining-forests

Myers, R., Intarini, D., Sirait, M. T., \& Maryudi, A. (2017). Claiming the forest: Inclusion and exclusion under Indonesia's "new" policy on cutomary forest. Land Use Policy, 66, 205-213.

Nick. (2014, 22 December 2017). From safeguards to safeguarding: Engaging indigenous peoples and local communities on REDD+. Mapping Environmental Justice. 17 July 2014. Retrieved 31 December 2017, 2017, from http://www.ejolt.org/2014/07/from-safeguards-tosafeguarding-engaging-indigenous-peoples-and-local-communitieson-redd/

Nizar, M. (2010). RTRW Aceh Harus Jamin Hak Masyarakat. Lingkungan Hidup. 15 August 2010. Retrieved 26 August 2010, 2010, from http://www.kabarindonesia.com/berita.php?pil=4\&jd=RTRW+Aceh+H arus+Jamin+Hak+Masyarakat\&dn=20100814121205

Nugroho, H. Y. S. H., van der Veen, A., Skidmore, A. K., \& Hussin, Y. A. (2017). Theoretical Framework for Spatial Planning and Forest Management in Indonesia: Securing The Basic Rights for ADAT People. Indonesian Journal of Forestry Research, 4(1), 15. doi: 10.20886/ijfr.2017.4.1.69-83

Pasgaard, M. (2013). The challenge of assessing social dimensions of avoided deforestation: Examples from Cambodia. Environmental Impact Assessment Review, 38(0), 64-72. doi: http://dx.doi.org/10.1016/j.eiar.2012.06.002

Pouliot, M., Treue, T., Obiri, B. D., \& Ouedraogo, B. (2012). Deforestation and the Limited Contribution of Forests to Rural Livelihoods in West Africa: Evidence from Burkina Faso and Ghana. Ambio, 41(7), 738750. doi: $10.1007 /$ s13280-012-0292-3 
Raharjo, O. P. (2014). Evaluating The Role of ADAT Community in Spatial Planning in Paser, East Kalimantan. (Master of Science Theses), University of Twente, The Netherlands.

Rhodes, R. A. W. (1996). The New Governance: Governing without Government1. Political Studies, 44(4), 652-667. doi: 10.1111/j.14679248.1996.tb01747.x

Rodríguez Bolívar, M. P., Navarro Galera, A., \& Alcaide Muñoz, L. (2015). Governance, transparency and accountability: An international comparison. Journal of Policy Modeling, 37(1), 136-174. doi: http://dx.doi.org/10.1016/j.jpolmod.2015.01.010

Royer, S. D., Visser, L. E., Galudra, G., Pradhan, U., \& Noordwijk, M. V. (2015). Self-identification of indigenous people in postindependence Indonesia: a historical analysis in the context of REDD+. International Forestry Review Vol.17(3).

Rudel, T. K., Defries, R., Asner, G. P., \& Laurance, W. F. (2009). Changing Drivers of Deforestation and New Opportunities for Conservation. Conservation Biology, 23(6), 1396-1405. doi: 10.1111/j.15231739.2009.01332.x

Rudel, T. K., Schneider, L., \& Uriarte, M. (2010). Forest transitions: An introduction. Land Use Policy, 27(2), 95-97. doi: http://dx.doi.org/10.1016/j.landusepol.2009.09.021

Sasaoka, M., \& Laumonier, Y. (2012). Suitability of Local Resource Management Practices Based on Supernatural Enforcement Mechanisms in the Local Social-cultural Context. Ecology and Society, 17(4). doi: 10.5751/ES-05124-170406

Seidenberg, C., Mertz, O., \& Kias, M. B. (2003). Fallow, labour and livelihood in shifting cultivation: implications for deforestation in northern Lao PDR. Danish Journal of Geography, 103 (2), 71-80.

Shearman, P. L., Ash, J., Mackey, B., Bryan, J. E., \& Lokes, B. (2009). Forest Conversion and Degradation in Papua New Guinea 1972-2002. Biotropica, 41(3), 379-390. doi: 10.1111/j.1744-7429.2009.00495.x

Tachibana, T., Nguyen, T. M., \& Otsuka, K. (2001). Agricultural Intensification versus Extensification: A Case Study of Deforestation in the Northern-Hill Region of Vietnam. Journal of Environmental Economics and Management, 41(1), 44-69. doi: http://dx.doi.org/10.1006/jeem.1998.1131

The Secretariat of the UN Permanent Forum on Indigenous Issues (2005). Engaging Indigenous Peoples in governance processes: International legal and policy frameworks for engagement. Paper presented at the International Conference on Engaging Communities, Brisbane, Australia.

The Union for Ethical BioTrade (2013). Fair and equitable benefit sharing, Manual for the assessment of policies and practices along natural ingredient supply chains: The Union for Ethical BioTrade 
Tomich, T. P., van Noordwjik, M., Budidarsono, S., Gillison, A. N., Kusumanto, T., Murdiyarso, D., . . . Fagi, A. M. (2001). Agricultural intensification, deforestation, and the environment: assessing tradeoffs in Sumatra, Indonesia Tradeoffs or synergies?: agricultural intensification, economic development, and the environment (pp. 221-244). Wallingford, Oxon, UK: CAB International

Tribun bisnis. (2017). Menko Darmin Mengaku Tidak Senang Masyarakat Klaim Punya Hak Atas Tanah ADAT. 26 March 2017. Retrieved 14 October 2017, 2017, from http://www.tribunnews.com/bisnis/2017/03/26/menko-darminmengaku-tidak-senang-masyarakat-klaim-punya-hak-atas-tanahADAT

Tyson, A. D. (2010). Decentralization and ADAT revivalism in Indonesia: The politics of becoming indigenous.

UNESCO. (2017). UNESCO Policy on Engaging with Indigenous Peoples ( $p p$. 26). Paris: UNESCO.

UNPO. (2014). West Papua: Indonesian Transmigration Program Further Marginalizes the Indigenous Population. 6 November 2015. Retrieved 3 October 2017, 2017, from http://unpo.org/article/17676

Wachira, G. M. (2010). Applying Indigenous Peoples' Customary Law in Order to Protect their Land Rights in Africa. In G. Rose \& J. Dahl (Eds.), Development and Customary Law (pp. 6-15). Copenhagen, Denmark: International Work Group for Indigenous Affairs 


\section{Summary}

Issues related to deforestation, land degradation, and disharmony between stakeholders, have formed an ongoing theme in many international forestrelated workshops, scientific journals and publications for more than three decades. This interest is motivated by significant global deforestation and its effect on government revenue, environmental degradation, and the livelihood opportunities of forest-dependent people (Boafo, 2013; UNEP, 2011, 2012). Empirical data across countries show that a main cause of forest destruction and conflict among stakeholders is weak governance, which is characterized by limited transparency, accountability, and participation (Carothers \& Brechenmacher, 2014; Drazkiewicz et al., 2015; Rodríguez Bolívar et al., 2015).

Although concerns related to weak forest governance did receive attention in various international forums, there is still limited knowledge about the effect on deforestation, degradation, and livelihoods at local levels, as well as how to address this issue to attain sustainable forest management (Blaser, 2010). The issues have been more problematic when they correlate with ownership issues, territory, and the basic right of indigenous community. For many indigenous peoples, the forest plays essential roles in ensuring their cultural, spiritual and economic well being (Kawharu, 2011).

The Indonesian term ADAT means 'custom' or 'tradition' (Henley \& Davidson, 2007). It is used to describe complex customary systems, including rights to land and resources, a wide range of traditional rules, social rule, customs, conventions, principles, moral concept and beliefs (Affandi, 2016; Royer et al., 2015; Rye \& Kurniawan, 2017; Tyson, 2010). The term ADAT carries connotations of serene order and consensus (Henley et al., 2007). Yet, interpretation of ADAT may vary within villages and between ethnic groups according to a wide variety of ADAT laws regulating access to land and resources (Royer et al., 2015; Tyson, 2010). The Indigenous Peoples Alliance of the Archipelago (AMAN) defines masyarakat ADAT as a group of people from the same ancestral lineages who inhabit a certain geographical area and have a distinctive set of ideological, economic, political, cultural and social systems and values, as well as a territory (AMAN, 2012).

Engaging with ADAT people in Sustainable Forest Management is not a simple process. The process of decentralization of forest management have failed to engage indigenous peoples and local communities in a meaningful way (Gooda, 2010; Nick, 2014). On the other side, there were numerous criticisms attacking overly exaggerated pictures of indigenous people (Grumblies, 2013; Muur, 2015). These critics related to a premise that indigenous peoples have changed in line with changes in economic and 
environmental conditions. The increase population and culture diversity in the region, contact with external people with different values and attitudes, increasing the necessities of life, and the need for cash might change the behavior towards nature of the indigenous people (Anthias, 2017; Huntington et al., 2004; Kothari, 2007; Luz et al., 2015; Muur, 2015).

In fact, most of the ADAT community territories are located within forest areas. According to AMAN (Aliansi Masyarakat ADAT Nusantara/Indigenous Peoples' Alliance of the Archipelago), 90 percent of at least 84 million ha of ADAT communities' territories are forest (Zakaria, 2017), which is, without special measures, potentially lead to claim contestation, conflict among stakeholder and forest destruction. Thus, practical approach are essential if sustainable forest management is to be achieved, considering the appropriate institution, mechanism and tools to design and implement the strategy.

Based on our study, there are two interrelated factors as a prerequisite of good quality forest-based spatial planning for achieving sustainable forest management considering ADAT rights : 1) Availability of an appropriate institution to formulate forest-based spatial planning law based on various resource, needs, and knowledge of multi stakeholders, and 2) Availability of appropriate mechanisms and tools to formulate sustainable forest management technologies based on comprehensive and accurate data and information.

By employing appropriate mechanism and tools in formulating SFM policy, the need to secure basic ADAT rights in balance with the need to attain sustainable forest management can be accommodated and tested transparently and scientifically. Our study proved that the use of mixed methods, a combination of image interpretation, spatial analysis, modeling, and thorough analysis of socio-economic and culture of how ADAT people manage their land, was able to develop better justification as a basis of policy development.

By using the area production model (APM), ILWIS-based Decision Support System, we were able to analyze the effect of improved farming systems, policy intervention and law enforcement on traditional land-use expansion and deforestation. Based on our examination of a 20-year period of traditional land-use activities in ADAT forests, the evidence indicated that the steeper the slope of the land and the farther the distance from the village, the lower the rate of deforestation. We reached the conclusion that ADAT people manage their forest sustainably. Since shifting cultivation has been part of ADAT culture for many generations, the solution is not to force them to convert to permanent agricultural systems. Rather, ensuring the security of land rights and assisting in the improvement of their shifting cultivation 
while moving toward more productive systems, with longer fallows, and providing better farming inputs and technology to maintain soil fertility.

Our study found that customary law, regulating traditional land-use, played an important role in controlling deforestation and land degradation. We conclude that the integration of land reallocation (tenure security), improved farming practices and enforcement of customary law are effective measures to improve traditional land productivity while avoiding deforestation and land degradation.

Using case study, we develop an approach in verification process of "de facto" recognition of ADAT rights over forest by assessing substantial evidences to support the existing legal formal evidence. Substantial evidence was analyzed to examine the capacity, capabilities and awareness of indigenous peoples to manage their territory sustainably using a combination of two methods: 1 ) analysis of map conformity as instrument of traditional knowledge assessment, and 2) analysis of historical land-use pattern as an instrument of ADAT law implementation assessment.

This approach was designed to ensure that the transfer of control rights over forest to certain group of people is not merely as a form of rights recognition, political persuasion, but also an attempt to ensure that the ADAT forest will remains sustainably for the benefit of ADAT community and the environment.

We were able to depict the de facto condition of ADAT people. Ancestral norms, beliefs and traditional wisdoms in general are owned and applied by ADAT people living around the GLPF. Nonetheless, increasing the necessities of life, better accessibility, and socio-culture assimilation changed the behavior towards nature of the ADAT people. Notwithstanding the social importance of customary land rights, our findings indicate that the critique of environmentalists regarding ADAT people might be justified.

Practical and systematic solutions to engage with ADAT people are essential if sustainable forest management is to be achieved, considering the appropriate institution, mechanism and tools to design and implement the strategy of sustainable forest management. The use of a scientific approach to determine who to be engage and how the forest should be managed becomes a must to ensure accountability of the policies taken. Long term engagement with ADAT people must be planned and implemented systematically to attain sustainable benefits of ADAT forest management. Formal law enforcement and revitalization of ADAT law are essential measures to be conducted in line with efforts to enhance the community welfare. Effective engagement underpins a commitment to re-arranging the relationships between government and ADAT people involving capacity and trust building and promoting dialogue. In the early step, there must be substantial evidence, 
logic and reasonable evidences resulted from adequate and well-controlled investigation, instead of merely based on legal formal evidences as a basis of handover of rights over forest.

Engagement in forest governance suggests interactions between a government and local communities (Holmes, 2011). In the context of engaging with ADAT people, this interaction is intended to builds trust and relationship between government and ADAT people. The closing the gap clearinghouse, a Councils of Australian Government (COAG) initiative, summarized that effective engagement requires a relationship built on trust and integrity: it is a sustained relationship between groups of people working towards shared goals; on the spectrum of engagement, a high level of participation works (Hunt, 2013).

Hence, the legitimation of the people to engage is the most essential factor. Engaging with people who are not legitimate ADAT or are but have little interest or capacity to manage forests may well result in not achieving SFM goals and lead to long-term conflicts in the future

Certain numbers of determinant factors must be overcome. In this thesis, we emphasize on 2 determinant factors of the engagement process: (1) confirmation of the legitimate status of the ADAT people concerned, and (2) the financial and technical capacity of these people.

Legitimation refers to whether the "indigenous" people we concerned about are really the people who deserve the rights of control over forest as being regulated by formal regulation. There are two issues to be considered. The first issue is the genuineness of the "indigenous people" and the second issue concerns the loss of indigenous purity (Anthias, 2017; Huntington et al., 2004; Kothari, 2007; Luz et al., 2015; Muur, 2015).

At least, we noticed three constraints and challenges in developing long term and good engagement with ADAT people. The first, relates to potential conflict due to the strict use of indigenous people terms in the recognition of ADAT forests, the second is the existence of regulations requiring local regulations and customary forest maps to support the recognition process, and the third are factors related to the actual condition of the ADAT people: ADAT purity abrasion (Anthias, 2017; Huntington et al., 2004; Klenke, 2013; Kothari, 2007; Luz et al., 2015; Muur, 2015), the weak institutional capacity (Chino \& DeBruyn, 2006; Escott et al., 2015; Tinus et al., 2014; Yunitasari, 2009), distrust and skepticism of ADAT people toward the state (Adji, 2016; Bond et al., 2012; Human Rights Council 2014; Mongabay, 2015), and economic pragmatism tendency (Fleming, 2015; Murniati et al., 2006; Nugroho et al., 2017; Wahyuni, 2011). 
Engaging with peopleis the basic condition to achieve the goals of SFM and avoid long-term conflicts in the future. A partial or sectoral formality approach with limited participation of ADAT people as well as "nonindigenous" people, will not work to foster long terms engagement. There must be substantial evidences, logic and reasonable evidences resulted from the adequate and well-controlled investigation, instead of on formality evidences, before the rights of control over land is transferred to the targeted people. The big concern must be addressed on: 1) detail verification of two aspects of the representativeness prerequisite on indigenous people: status legitimation and the capacity of the indigenous people, 2) anticipation of potential conflict as excesses of the strict use of indigenous people terms and the unilaterally claim of territory, and 3) supervision, assistance, building of institutional, technical, and financial capacity of ADAT people to manage and utilize their ADAT forest sustainably, and promoting continuous dialogs to maintain the established commitments.

We suggest that various parties, especially the government and ADAT people, should take an active role in developing collective actions to ensure that the ADAT forest will be managed sustainably. The right of permanent sovereignty over natural resources should be an instrument of the alleviation of poverty, physical and cultural survival, and ADAT law-based social and economic development. ADAT law must be revitalized and empowered in accordance with formal state regulation enforcement.

\section{References}

Adji, B. (2016). Penetapan Kawasan Hutan ADAT Dinilai Lamban. 5 Desember 2016. Retrieved 30 Maret 2018, 2018, from http://www.harnas.co/2016/12/05/penetapan-kawasan-hutan-ADATdinilai-lamban

Affandi, D. Y. (2016). Negoitating ADAT. 22 Fepbruary 2016. Retrieved 20 September 2017, 2017, from http://www.insideindonesia.org/negotiating-ADAT

AMAN. (2012). REPUBLIC OF INDONESIA Country Technical Notes on Indigenous Peoples' Issues: IFAD.

Anthias, P. (2017). Ch'ixi landscapes: Indigeneity and capitalism in the Bolivian Chaco. Geoforum, 82(Supplement C), 268-275. doi: https://doi.org/10.1016/j.geoforum.2016.09.013

Blaser, J. (2010). Forest law compliance and governance in tropical countries, A region-by-region assessment of the status of forest law compliance and governance, and recommendations for improvement. In A. Sarre (Ed.), (pp. 1-28): FAO and ITTO.

Boafo, J. (2013). The Impact of Deforestation on Forest Livelihoods in Ghana. BACKGROUNDER. AFRICAPORTAL. Retrieved from 
http://www.africaportal.org/sites/default/files/Africa\%20Portal\%20Ba ckgrounder\%20No.\%2049.pdf

Bond, C., Brough, M., Spurling, G., \& Hayman, N. (2012). 'It had to be my choice' Indigenous smoking cessation and negotiations of risk, resistance and resilience. Health, Risk \& Society, 14(6), 565-581. doi: $10.1080 / 13698575.2012 .701274$

Carothers, T., \& Brechenmacher, S. (2014). Accountability, transparency, participation, and inclusion, a new development consensus? Washington DC: Carnegie Endowment for International Peace.

Chino, M., \& DeBruyn, L. (2006). Building True Capacity: Indigenous Models for Indigenous Communities. American Journal of Public Health, 96(4), 596-599. doi: 10.2105/ajph.2004.053801

Drazkiewicz, A., Challies, E., \& Newig, J. (2015). Public participation and local environmental planning: Testing factors influencing decision quality and implementation in four case studies from Germany. Land Use Policy, 46, 211-222. doi: http://dx.doi.org/10.1016/j.landusepol.2015.02.010

Escott, H., Beavis, S., \& Reeves, A. (2015). Incentives and constraints to Indigenous engagement in water management. Land Use Policy, 49(Supplement C), 382-393. doi: https://doi.org/10.1016/j.landusepol.2015.08.003

Fleming, A. E. (2015). Improving Business Investment Confidence in CultureAligned Indigenous Economies in Remote Australian Communities: A Business Support Framework to Better Inform Government Programs. The International Indigenous Policy Journal, $6(3$ (5)). doi: 10.18584/iipj.2015.6.3.5

Gooda, M. (2010). Social Justice and Aboriginal and Torres Strait Islander peoples access to services. Paper presented at the QCOSS Regional Conference: Building a Better Future-themed around improving service delivery for regional and remote communities. https://www.humanrights.gov.au/news/speeches/social-justice-andaboriginal-and-torres-strait-islander-peoples-access-services-2010

Grumblies, A.-T. (2013). Being Wana, Becoming an "Indigenous People". Experimenting with Indigeneity in Central Sulawesi. In B. HauserSchäublin (Ed.), ADAT and Indigeneity in Indonesia Culture and Entitlements between Heteronomy and Self-Ascription (Vol. 7, pp. 82-98). Göttingen: Göttingen University Press

Henley, D., \& Davidson, J. S. (2007). Introduction: radical conservatism - the protean politics of ADAT. In J. S. Davidson \& D. Henley (Eds.), The Revival of Tradition in Indonesian, Politics The deployment of ADAT from colonialism to indigenism (pp. 1-49). New York: Routledge

Holmes, B. (2011) Citizens' engagement in policymaking and the design of public services. Vol. Research Paper No. 1, 2011-12 (22 July 2011 ed.). Canberra, Australia: Department of Parliamentary Services. 
Human Rights Council (2014). The situation of indigenous peoples in Canada Report of the Special Rapporteur on the rights of indigenous peoples, James Anaya: Human Rights Council, General Assembly, The United Nations.

Hunt, J. (2013). Engaging with Indigenous Australia-exploring the conditions for effective relationships with Aboriginal and Torres Strait Islander communities Issues paper no. 5. Produced for the Closing the Gap Clearinghouse. (pp. 53). Canberra: Australian Institute of Health and Welfare \& Melbourne: Australian Institute of Family Studies.

Huntington, H., Callaghan, T., Fox, S., \& Krupnik, I. (2004). Matching traditional and scientific observations to detect environmental change : A discussion on Arctic terrestrial ecosystems. Ambio(13), 18-23.

Kawharu, M. (2011). Forestry and indigenous issues: New Zealand and the Pacific. Paper presented at the International Expert Group Meeting Indigenous Peoples and Forests, New York.

Klenke, K. (2013). Whose ADAT is it? ADAT, Indigeneity and Social Stratification in Toraja. In B. Hauser-Schäublin (Ed.), ADAT and Indigeneity in Indonesia Culture and Entitlements between Heteronomy and Self-Ascription (Vol. 7, pp. 149-166). Göttingen: Göttingen University Press

Kothari, A. (2007). Traditional Knowledge and Sustainable Development. Manitoba, Canada: International Institute for Sustainable Development (IISD).

Luz, A., Guèze, M., Paneque-Gálvez, J., Pino, J., Macía, M., Orta-Martínez, M., \& Reyes-García, V. (2015). How Does Cultural Change Affect Indigenous Peoples' Hunting Activity? An Empirical Study Among the Tsimane' in the Bolivian Amazon. Conservation and Society, 13(4), 382-394. doi: 10.4103/0972-4923.179879

Mongabay. (2015). Dari Rakernas AMAN: Mendagri Bicara Soal Percepatan Pengakuan dan Perlindungan Masyarakat ADAT. 20 March 2015. Retrieved 30 March 2018, 2018, from http://www.mongabay.co.id/2015/03/20/dari-rakernas-amanmendagri-bicara-soal-percepatan-pengakuan-dan-perlindunganmasyarakat-ADAT/

Murniati, Padmanaba, M., Basuki, I., \& van der Ploeg, J. (2006). Gunung Lumut biodiversity assessment socio-economic study: how important forest and landscape resource for community living in and around Gunung Lumut protection forest? Final report to TROPENBOS. Bogor, Indonesia: Center for International Forestry Research (CIFOR).

Muur, W. v. d. (2015). Will customary land rights destroy Indonesia's last remaining forests? Retrieved 25 April 2015, 2015, from http://leidenlawblog.nl/articles/will-customary-land-rights-destroyindonesias-last-remaining-forests 
Nick. (2014, 22 December 2017). From safeguards to safeguarding: Engaging indigenous peoples and local communities on REDD+. Mapping Environmental Justice. 17 July 2014. Retrieved 31 December 2017, 2017, from http://www.ejolt.org/2014/07/from-safeguards-tosafeguarding-engaging-indigenous-peoples-and-local-communitieson-redd/

Nugroho, H. Y. S. H., van der Veen, A., Skidmore, A. K., \& Hussin, Y. A. (2017). Expansion of traditional land-use and deforestation: a case study of an ADAT forest in the Kandilo Subwatershed, East Kalimantan, Indonesia. Journal of Forestry Research. doi: 10.1007/s11676-017-0449-9

Rodríguez Bolívar, M. P., Navarro Galera, A., \& Alcaide Muñoz, L. (2015). Governance, transparency and accountability: An international comparison. Journal of Policy Modeling, 37(1), 136-174. doi: http://dx.doi.org/10.1016/j.jpolmod.2015.01.010

Royer, S. D., Visser, L. E., Galudra, G., Pradhan, U., \& Noordwijk, M. V. (2015). Self-identification of indigenous people in postindependence Indonesia: a historical analysis in the context of REDD+. International Forestry Review Vol.17(3).

Rye, S. A., \& Kurniawan, N. I. (2017). Claiming indigenous rights through participatory mapping and the making of citizenship. Political Geography, 61(Supplement $\quad$ C), 148-159. doi: https://doi.org/10.1016/j.polgeo.2017.08.008

Tinus, O., Murianson, Gunawan, J., Nurhayati, L., \& Diprose, R. (2014). Dukungan Penguatan Kelembagaan Bagi Desa dalam Mengelola Kegiatan REDD+, Sebuah Pembelajaran Lapangan dari Demonstrasi REDD+ di Kabupaten Kapuas, Provinsi Kalimantan Tengah Jakarta: Kalimantan Forests and Climate Partnership, Indonesia-Australia Forest Carbon Partnership.

Tyson, A. D. (2010). Decentralization and ADAT revivalism in Indonesia: The politics of becoming indigenous.

UNEP. (2011). Emerging Perspectives on Forest Biodiversity UNEP Year Book 2011: United Nations Environment Programme

UNEP. (2012). Deforestation Costing Kenyan Economy Millions of Dollars Each Year and Increasing Water Shortage Risk. 5 November 2012. Retrieved 13 May, 2013, from http://www.unep.org/Documents.Multilingual/Default.asp?DocumentI $D=2698 \&$ ArticleID $=9316 \& I=$ en

Wahyuni, T. (2011). Can traditional forest management protect and conserve ironwood (ulin) stands? An option and approach in East Kalimantan. (Doctor), University of Leiden, Leiden, The Netherlands.

Yunitasari. (2009). Pengembangan Kapasitas Kelembagaan Masyarakat ADAT dalam Merespon Program Pemberdayaan. (Magister Profesional Tesis), Institut Pertanian Bogor, Bogor. 
Zakaria, Y. (2017, 10 February 2017). After the customary forest recognition. 26 January 2017. Retrieved 10 February 2017, 2017, from http://www.thejakartapost.com/academia/2017/01/26/after-thecustomary-forest-recognition.html 


\section{Samenvatting}

Kwesties in verband met ontbossing, gradatie, en disharmonie tussen stakeholders, hebben een gevormd lopende thema in vele internationale bosgerelateerde workshops, wetenschappelijke tijdschriften en publicaties voor meer dan drie decennia. Deze rente is ingegeven door aanzienlijke wereldwijde ontbossing en het effect ervan op de overheidsinkomsten, milieu gradatie, en de middelen van bestaan van het bos afhankelijk zijn mensen (Boafo 2013, UNEP, 2011, 2012). Empirische gegevens over landen laten zien dat een belangrijke oorzaak van bosvernietiging en conflict tussen belanghebbenden wordt toegeschreven aan zwak bestuur, die wordt gekenmerkt door beperkte transparantie, verantwoordingsplicht en participatie (Carothers \& Brechenmacher, 2014; Drazkiewicz et al., 2015; Rodríguez Bolívar et al., 2015).

Hoewel bezorgdheid met betrekking tot zwak bosbeheer aandacht kreeg in verschillende internationale fora, is er nog steeds beperkte kennis over het effect op ontbossing, ontvettingsvermogen en middelen van bestaan op lokaal niveau, en hoe dit probleem kan worden aangepakt om duurzaam bosbeheer te bereiken (Blaser, 2010). De problemen zijn problematischer geweest wanneer ze verband houden met eigendomskwesties, territorium en het basisrecht van de inheemse gemeenschap. Voor veel inheemse mensen, het bos speelt een essentiële rol bij het waarborgen van hun culturele, spirituele en economische goed zijn (Kawharu, 2011).

De Indonesische term ADAT betekent 'maatwerk' of 'traditie' (Henley \& Davidson, 2007). Het wordt gebruikt om complexe gebruikelijke systemen, met inbegrip van rechten op land en hulpbronnen, een breed scala aan traditionele regels, sociale regel beschrijven, douane, conventies, principes, morele begrippen en overtuigingen (Affandi, 2016; Royer et al, 2015.; Rye \& Kurniawan, 2017; Tyson, 2010). De term ADAT heeft connotaties van serene orde en consensus (Henley et al., 2007). De interpretatie van ADAT kan echter variëren binnen dorpen en tussen etnische groepen volgens een grote verscheidenheid aan ADAT-wetten die de toegang tot land en hulpbronnen reguleren (Royer et al., 2015; Tyson, 2010). De Inheemse Volkeren Alliantie van de Archipel (AMAN) definieert masyarakat ADAT als een groep mensen uit dezelfde voorouders die een bepaald geografisch gebied bewonen en een onderscheidende set van ideologische, economische, politieke, culturele en sociale systemen en waarden hebben, evenals als een territorium (AMAN, 2012).

Het aangaan van ADAT-mensen in duurzaam bosbeheer is geen eenvoudig proces. Het proces van decentralisatie van het bosbeheer hebben gefaald en geleid tot de inheemse mensen te betrekken en lokale gemeenschappen op 
een zinvolle manier (Gooda, 2010; Nick, 2014). Aan de andere kant waren er talloze kritieken die overdreven foto's van inheemse mensen aanvielen (Grumblies, 2013; Muur, 2015). Deze critici hadden betrekking op een premisse dat inheemse mensen zijn veranderd in overeenstemming met veranderingen in economische en ecologische omstandigheden. De toename van bevolking en cultuurdiversiteit in de regio, contact met externe mensen met verschillende waarden en attitudes, verhoging van de levensbehoeften en de behoefte aan contant geld kan het gedrag ten opzichte van de aard van de inheemse bevolking veranderen (Anthias, 2017; Huntington et al., 2004; Kothari, 2007; Luz et al., 2015; Muur, 2015).

In feite bevinden de meeste ADAT-gemeenschapsgebieden zich in bosgebieden. Volgens AMAN (Aliansi Masyarakat ADAT Nusantara) Alliantie van de Archipel, 90 procent van ten minste 84 miljoen hectare van inheemse volkeren) ADAT communities' gebieden zijn bos (Zakaria, 2017), die zou kunnen, zonder speciale maatregelen, mogelijk leiden tot vordering wedstrijd, conflict tussen belanghebbenden en bosvernietiging. Daarom is een praktische aanpak essentieel om duurzaam bosbeheer te bereiken, rekening houdend met de juiste instelling, het juiste mechanisme en de juiste instrumenten om de strategie te ontwerpen en uit te voeren.

Op basis van ons onderzoek, zijn er twee met elkaar samenhangende factoren als een voorwaarde voor goede kwaliteit houtverwerkende ruimtelijke ordening voor het bereiken van een duurzaam bosbeheer overweegt ADAT rechten: 1) De beschikbaarheid van een geschikte instelling om de houtverwerkende ruimtelijke ordeningsrecht te formuleren op basis van verschillende resource, behoeften en kennis van multi-stakeholders. 2) Beschikbaarheid van geschikte mechanismen en hulpmiddelen om duurzame bosbeheertechnologieën te formuleren op basis van uitgebreide en nauwkeurige gegevens en informatie.

Door de juiste mechanismen en instrumenten te gebruiken bij het formuleren van SFM-beleid, kan de noodzaak om basis ADAT rechten veilig te stellen in evenwicht met de noodzaak om duurzaam bosbeheer te bereiken, transparant en wetenschappelijk worden ondergebracht en getest. Onze studie bewees dat het gebruik van gemengde methoden (een combinatie van beeldinterpretatie, ruimtelijke analyse, modellering en grondige analyse van sociaal-economische en cultuur van hoe ADAT mensen hun land beheren) een betere rechtvaardiging kon ontwikkelen als basis voor beleid ontwikkeling.

Door het gebiedsproductiemodel (APM), het op ILWIS gebaseerde beslissing ondersteuningssysteem, te gebruiken, konden we het effect analyseren van verbeterde landbouwsystemen, beleidsinterventie en wetshandhaving op traditionele uitbreiding en ontbossing van landgebruik. Op basis van ons 
onderzoek van een periode van 20 jaar van traditionele activiteiten op het gebied van landgebruik in ADAT-bossen, wees het bewijs erop dat hoe steiler de helling van het land en hoe verder de afstand van het dorp, hoe lager de ontbossingsgraad. We kwamen tot de conclusie dat ADAT-mensen hun bos duurzaam beheren. Omdat verschuivende teelt al vele generaties deel uitmaakt van de ADAT-cultuur, is de oplossing niet om hen te dwingen om over te schakelen naar permanente landbouwsystemen, maar eerder om de veiligheid van landrechten te waarborgen. Ook is het nodig om hen te helpen bij de verbetering van hun zwerflandbouw tijdens het verplaatsen in de richting van meer productieve systemen, met langere Fallows, en een betere landbouw-ingangen en technologie om de bodemvruchtbaarheid te behouden.

Onze studie bleek dat gewoonterecht regulering van traditionele landgebruik, speelde een belangrijke rol in de controle van ontbossing en degradatie. We concluderen dat de integratie van ruilverkaveling (tenure security), verbeterde landbouwpraktijken en handhaving van het gewoonterecht effectiviteit van de maatregelen om de traditionele productiviteit van de grond te verbeteren, terwijl het vermijden van ontbossing en degradatie.

Aan de hand van een case studie ontwikkelen we een aanpak in het verificatieproces van "de facto" erkenning van ADAT rechten op bos door substantiële bewijzen te beoordelen ter ondersteuning van het bestaande juridische formele bewijsmateriaal. Substantieel bewijs is analyse geweest om de capaciteit, de mogelijkheden en het bewustzijn van de inheemse onderzoeken mensen om hun territorium te beheren duurzaam gebruik van een combinatie van twee methoden 1) analyse van de kaart conformiteit als instrument van traditionele kennis assessment, en 2) analyse van historische land-: gebruik patroon als instrument voor de beoordeling van de implementatie van ADAT-wetgeving.

Deze aanpak was bedoeld om ervoor te zorgen dat de overdracht van controlerechten over bos aan bepaalde groepen mensen niet alleen als een vorm van rechtenherkenning, politieke overtuiging, maar ook een poging is om ervoor te zorgen dat het ADAT-bos duurzaam zal blijven ten behoeve van ADAT gemeenschap en het milieu.

We konden de feitelijke situatie van ADAT-mensen weergeven. Voorouderlijke normen, overtuigingen en traditionele wijsheden in het algemeen zijn eigendom van en worden toegepast door ADAT-mensen die rond de GLPF wonen. Niettemin veranderde het vergroten van de levensbehoeften, betere toegankelijkheid en assimilatie van de sociale cultuur het gedrag ten opzichte van de aard van de ADAT-mensen. Ondanks het maatschappelijke belang van de gebruikelijke landrechten, geven onze bevindingen aan dat de kritiek van milieuactivisten op ADAT-mensen gerechtvaardigd kan zijn. 
Praktische en systematische oplossingen om met ADAT-mensen in contact te komen zijn essentieel om duurzaam bosbeheer te bereiken, rekening houdend met de juiste instelling, het juiste mechanisme en de juiste hulpmiddelen om de strategie van duurzaam bosbeheer te ontwerpen en te implementeren. Het gebruik van een wetenschappelijke benadering om te bepalen wie betrokken moet worden en hoe het bos moet worden beheerd, is een must om de verantwoording van het gevoerde beleid te waarborgen. Langetermijnbetrokkenheid met ADAT-mensen moet systematisch worden gepland en geïmplementeerd om duurzame voordelen van ADAT-bosbeheer te bereiken. Formele wetshandhaving en revitalisering van ADAT-wetgeving zijn essentiële maatregelen die moeten worden uitgevoerd in overeenstemming met inspanningen om het welzijn van de gemeenschap te verbeteren. Effectieve betrokkenheid onderbouwt een verplichting om de relaties tussen de overheid en ADAT-mensen opnieuw in te richten, waarbij capaciteit en vertrouwen worden opgebouwd en de dialoog wordt bevorderd. In de vroege stap moeten er substantieel bewijsmateriaal, logica en redelijk bewijsmateriaal zijn dat is voortgekomen uit adequaat en goed gecontroleerd onderzoek, in plaats van alleen gebaseerd op wettelijk formeel bewijsmateriaal als basis voor de overdracht van rechten over bos.

Betrokkenheid bij bosbeheer suggereert interacties tussen een overheid en lokale gemeenschappen (Holmes, 2011). In de context van het aangaan van ADAT-mensen is deze interactie bedoeld om vertrouwen en relaties tussen de overheid en ADAT-mensen op te bouwen. Het sluiten van het gap clearinghouse, een initiatief van de Councils of Australian Government (COAG), vat samen dat effectieve engagement een relatie vereist die is gebaseerd op vertrouwen en integriteit: het is een duurzame relatie tussen groepen mensen die werken aan gedeelde doelen; op het gebied van betrokkenheid werkt een hoog niveau van participatie (Hunt, 2013).

Daarom is de legitimatie van de mensen om deel te nemen de meest essentiële factor.

Het aangaan van mensen die geen legitieme ADAT zijn of die maar weinig interesse of capaciteit hebben om bossen te beheren, kan er toe leiden dat SFM-doelen niet worden bereikt en in de toekomst tot langdurige conflicten leiden

Bepaalde aantallen bepalende factoren moeten worden overwonnen. In dit proefschrift, benadrukken op twee bepalende factoren van de opdracht proces: (1) een bevestiging van de wettige status van de ADAT betrokkenen, en (2) de financiële en technische capaciteit van deze mensen.

Legitimatie verwijst naar de vraag of de "inheemse" mensen werkelijk de mensen zijn die het recht op controle over bos verdienen, zoals gereguleerd 
door formele regelgeving. Er zijn twee kwesties waarmee rekening moet worden gehouden. De eerste kwestie is de echtheid van de 'inheemse bevolking' en de tweede kwestie betreft het verlies van inheemse zuiverheid (Anthias, 2017; Huntington et al., 2004; Kothari, 2007; Luz et al., 2015; Muur, 2015).

We hebben tenminste drie beperkingen en uitdagingen opgemerkt bij het ontwikkelen van langdurige en goede betrokkenheid bij ADAT-mensen. De eerste heeft betrekking op potentieel conflict vanwege het strikte gebruik van inheemse volkeren termen bij de erkenning van ADAT-bossen, de tweede is het bestaan van voorschriften die lokale voorschriften en gebruikelijke boskaarten vereisen ter ondersteuning van het herkenningsproces, en de derde zijn factoren die verband houden met de werkelijke toestand van de ADAT mensen: ADAT zuiverheid schuren (Anthias, 2017; Huntington et al., 2004; Klenke 2013; Kothari, 2007; Luz et al, 2015; Muur, 2015.), de zwakke institutionele capaciteit (Chino \& DeBruyn, 2006; Escott et al., 2015; Tinus et al., 2014; Yunitasari, 2009), wantrouwen en scepsis van ADAT-mensen jegens de staat (Adji, 2016; Bond et al., 2012; Human Rights Council 2014; Mongabay , 2015) en neiging tot economisch pragmatisme (Fleming, 2015; Murniati et al., 2006; Nugroho et al., 2017; Wahyuni, 2011).

Betrokkenheid met mensen is de basisvoorwaarde om de doelen van SFM te bereiken en langdurige conflicten te voorkomen. Een gedeeltelijke of sectorale formaliteitsbenadering met beperkte deelname van ADAT-mensen en 'niet-inheemse' mensen, zal niet werken om langdurige betrokkenheid te bevorderen. Er moeten substantiële bewijzen zijn, logica en redelijke bewijzen die het resultaat zijn van adequaat en goed gecontroleerd onderzoek, in plaats van formaliteitsbewijzen, voordat de rechten van controle over land worden overgedragen aan de beoogde mensen. De grote zorg moet worden aangepakt op: 1) gedetailleerde verificatie van twee aspecten van de representativiteitsvoorwaarde voor inheemse volkeren: statuslegitimatie en de capaciteit van de inheemse bevolking, 2) anticipatie op potentieel conflict als excessen van het strikte gebruik van inheemse bevolkingstermen en de eenzijdige claim van territorium, en 3) supervisie, assistentie, opbouw van institutionele, technische en financiële capaciteit van ADAT-mensen om hun ADAT-bos duurzaam te beheren en te gebruiken, en het bevorderen van continue dialogen om de vastgelegde verplichtingen na te komen.

We stellen voor dat verschillende partijen, met name de overheid en ADATmensen, een actieve rol moeten spelen bij het ontwikkelen van collectieve acties om ervoor te zorgen dat het ADAT-bos duurzaam wordt beheerd. Het recht op permanente soevereiniteit over natuurlijke hulpbronnen moet een instrument zijn voor de verlichting van armoede, fysieke en culturele 
overleving en op ADAT gebaseerde wettelijke en sociale en economische ontwikkeling. De ADAT-wetgeving moet nieuw leven worden ingeblazen en in overeenstemming worden gebracht met de handhaving van formele overheidsvoorschriften. 


\section{Curriculum Vitae}

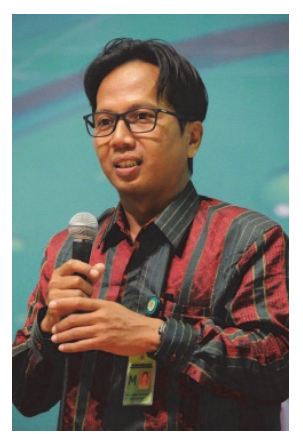

Hunggul Yudono Setio Hadi Nugroho was born in Yogyakarta, Indonesia in 7 November 1967. After finishing his senior high school in Yogjakarta, Indonesia, he continued to study at Bogor Agriculture University (IPB) in 1985. He graduated from IPB in March 1991 receiving a Bachelor of Forestry degree. Starting from 1993 to 2006 he worked as a researcher in the Research and Development Institute of Watershed Management Technology for Eastern Indonesia in Macassar, South Sulawesi. In 1998 he was awarded a grant by the Indonesian government to study in Watershed management, at the Bogor Agricultural Institute (IPB), Bogor, Indonesia and was awarded a Master of Science in 2000. Since May 2006 he is working as a researcher in the Forestry Research Institute of Macassar, South Sulawesi. In 2010 he was awarded a second scholarship, this time through the Tropenbos International, to conduct a Doctoral Program at the Faculty of Geo-Information Science and Earth Observation, University of Twente, The Netherlands. During his work as a researcher, he got four awards, in which the first two were awarded by Minister of Research and Technology, The Republic of Indonesia as one of the best innovator in 2010 and 2012, the third was the Minister Award from The Ministry of Forestry, awarded in 2012 as an outstanding performance researcher, and the fourth was from The Ministry of State Apparatus Empowerment and Buerocracy Reformation as The Top 5 Inspirational Government Employee of 2018 in National Level. 